In cooperation with the California State Water Resources Control Board A product of the California Groundwater Ambient Monitoring and Assessment (GAMA) Program

\title{
Groundwater-Quality Data in the South Coast Interior Basins Study Unit, 2008: Results from the California GAMA Program
}

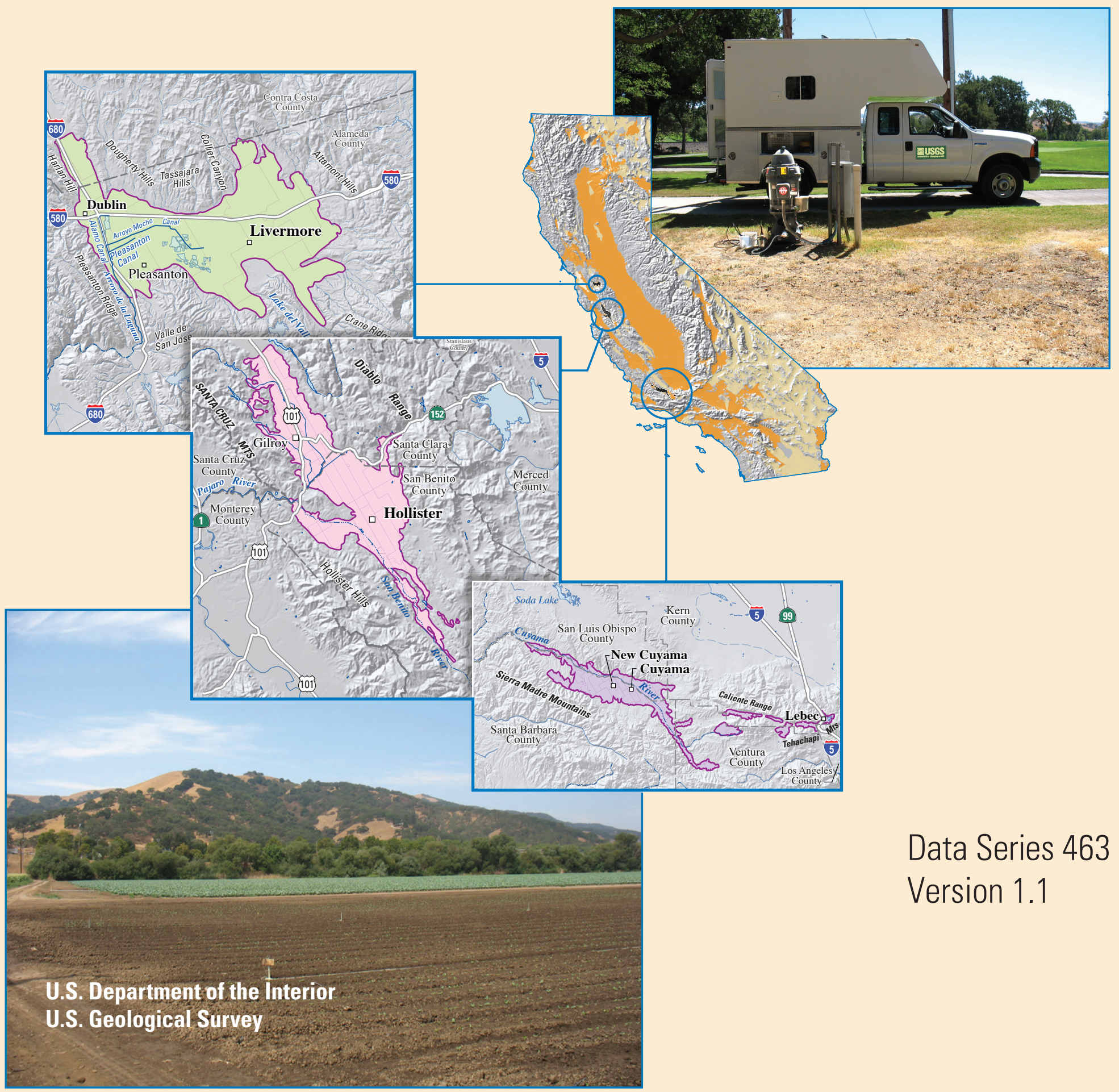


Cover Photographs:

Top right: Golf course irrigation well, Pleasonton, California. (Photograph taken by Tracy Davis, U.S. Geological Survey.)

Bottom left: Farm in Gilroy, California. (Photograph taken by Michael Land, U.S. Geological Survey.) 


\section{Groundwater-Quality Data in the South Coast Interior Basins Study Unit, 2008: Results from the California GAMA Program}

By Timothy M. Mathany, Justin T. Kulongoski, Mary C. Ray, and Kenneth Belitz

Prepared in cooperation with the California State Water Resources Control Board

Data Series 463

Version 1.1 


\title{
U.S. Department of the Interior \\ KEN SALAZAR, Secretary
}

\section{U.S. Geological Survey \\ Suzette M. Kimball, Acting Director}

\author{
U.S. Geological Survey, Reston, Virginia: 2009 \\ Revised 2010
}

\begin{abstract}
For more information on the USGS — the Federal source for science about the Earth, its natural and living resources, natural hazards, and the environment, visit http://www.usgs.gov or call 1-888-ASK-USGS

For an overview of USGS information products, including maps, imagery, and publications, visit http://www.usgs.gov/pubprod

To order this and other USGS information products, visit http://store.usgs.gov
\end{abstract}

\begin{abstract}
Any use of trade, product, or firm names is for descriptive purposes only and does not imply endorsement by the U.S. Government.

Although this report is in the public domain, permission must be secured from the individual copyright owners to reproduce any copyrighted materials contained within this report.
\end{abstract}

Suggested citation:

Mathany, T.M., Kulongski, J.T., Ray, M.C., and Belitz, Kenneth, 2009, Groundwater-quality data in the South Coast Interior Basins study unit, 2008: Results from the California GAMA program: U.S. Geological Survey Data Series 463, 82 p. Available at http://pubs.usgs.gov/ds/463. 


\section{Contents}

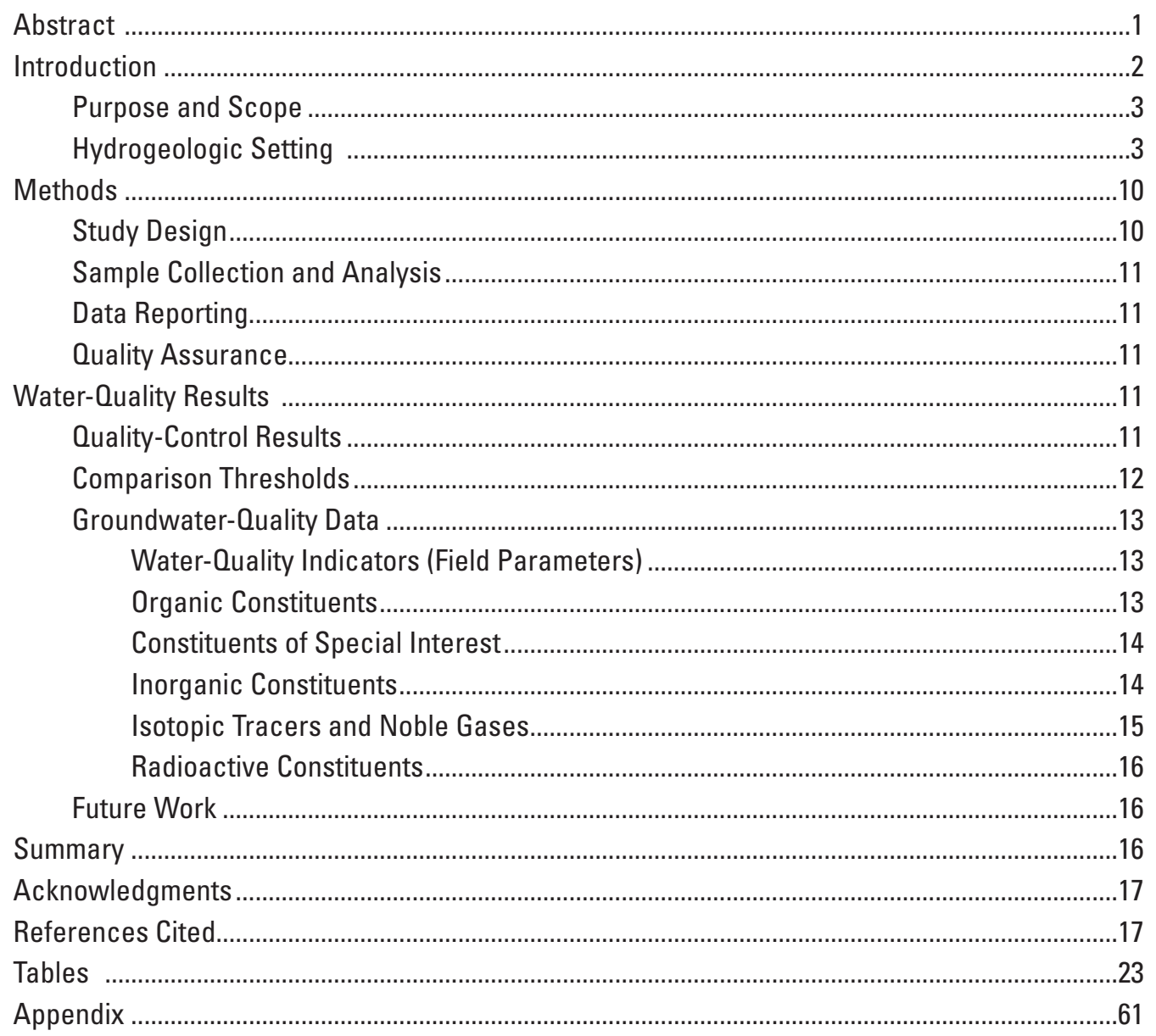




\section{Figures}

Figure 1. Map of the hydrogeologic provinces of California and the location of the South Coast Interior Basins Groundwater Ambient Monitoring and Assessment (GAMA) study unit.

Figure 2. Map of the South Coast Interior Basins Groundwater Ambient Monitoring and Assessment (GAMA) study unit showing the three study areas (Livermore, Gilroy, and Cuyama), the location of public-supply wells with a record in the California Department of Public Health (CDPH) Database, major cities, topographic features, and hydrologic features

Figure 3. Map of the South Coast Interior Basins Groundwater Ambient Monitoring and Assessment (GAMA) study unit showing the distribution of the Livermore studyarea grid cells, the location of sampled grid wells and understanding wells, the Livermore Valley groundwater-basin boundary (as defined by the California Department of Water Resources, CDWR), major cities, major roads, topographic features, and hydrologic features

Figure 4. Map of the South Coast Interior Basins Groundwater Ambient Monitoring and Assessment (GAMA) study unit showing the distribution of the Gilroy study-area grid cells, the location of sampled grid wells and understanding wells, the GilroyHollister groundwater-basin boundary (as defined by the California Department of Water Resources, CDWR), major cities, major roads, topographic features, and hydrologic features.

Figure 5. Map of the South Coast Interior Basins Groundwater Ambient Monitoring and Assessment (GAMA) study unit showing the distribution of the Cuyama study area-grid cells, the location of sampled grid wells and understanding wells, the Cuyama Valley, Castaic Lake Valley, Cuddy Canyon Valley, Cuddy Ranch Area, Cuddy Valley, and Mil Potrero groundwater-basin boundaries (as defined by the California Department of Water Resources, CDWR), major cities, major roads, topographic features, and hydrologic features.

\section{Tables}

Table 1. Identification, sampling, and construction information for wells sampled for the South Coast Interior Basins Groundwater Ambient Monitoring and Assessment (GAMA) study, California, August to December 2008.

Table 2. Classes of chemical consistuents and water-quality indicators (field parameters) collected for the slow and fast well sampling schedules in the South Coast Interior Basins Groundwater Ambient Monitoring and Assessment (GAMA) study, California, June to November 2008.

Table 3A. Volatile organic compounds (VOCs), primary uses or sources, comparative thresholds, and reporting information for the U.S. Geological Survey National Water Quality Laboratory Schedule 2020.. 
Table 3B. Pesticides and pesticide degradates, primary uses or sources, comparative thresholds, and reporting information for the U.S. Geological Survey National Water Quality Laboratory Schedule 2003

Table 3C. Polar pesticides and metabolites, primary uses or sources, comparative thresholds, and reporting information for the U.S. Geological Survey National Water Quality Laboratory Schedule 2060

Table 3D. Pharmaceutical compounds, primary uses or sources, comparative thresholds, and reporting information for the U.S. Geological Survey National Water Quality Laboratory Schedule 2080

Table 3E. Constituents of special interest (perchlorate and $N$-nitrosodimethylamine [NDMA]), primary uses or sources, comparative thresholds, and reporting information for Weck Laboratories, Inc. analyses

Table 3F. Trace elements, comparative thresholds, and reporting information for the U.S. Geological Survey National Water Quality Laboratory Schedule 1948

Table 3G. Nutrients, comparative thresholds, and reporting information for the U.S. Geological Survey National Water Quality Laboratory Schedule 2755.

Table 3H. Major and minor ions, silica, total dissolved solids (TDS), and alkalinity, comparative thresholds, and reporting information for the U.S. Geological Survey National Water Quality Laboratory Schedule 1948

Table 3l. Arsenic, chromium, and iron species, comparative thresholds, and reporting information for the U.S. Geological Survey Trace Metal Laboratory, Boulder, Colorado, analyses.

Table 3J. Isotopic and radioactive constituents, comparative thresholds, and reporting information for laboratory analyses.

Table 3K. Noble gases and tritium, comparison thresholds, and reporting information for the Lawrence Livermore National Laboratory analyses

Table 4. Water-quality indicators (field parameters) in samples collected for the South Coast Interior Basins Groundwater Ambient Monitoring and Assessment (GAMA) study unit, California, August to December 2008.

Table 5. Volatile organic compounds (VOCs) detected in samples collected for the South Coast Interior Basins Groundwater Ambient Monitoring and Assessment (GAMA) study, California, August to December 2008..

Table 6A. Pesticides and pesticide degradates detected in samples collected for the South Coast Interior Basins Groundwater Ambient Monitoring and Assessment (GAMA) study unit, California, August to December 2008.

Table 6B. Polar pesticides and metabolites detected in samples collected for the South Coast Interior Basins Groundwater Ambient Monitoring and Assessment (GAMA) study, California, August to December 2008

Table 7. Constituents of special interest ([perchlorate and $\mathrm{N}$-nitrosodimethylamine [NDMA]) collected for the South Coast Interior Basins Groundwater Ambient Monitoring and Assessment (GAMA) study, California, August to December 2008...47

Table 8. Trace elements collected for the South Coast Interior Basins Groundwater Ambient Monitoring and Assessment (GAMA) study, California, August to December 2008. 
Table 9. Nutrients detected in samples collected for the South Coast Interior Basins Groundwater Ambient Monitoring and Assessment (GAMA) study, California, August to December 2008

Table 10. Major and minor ions, silica, and total dissolved solids (TDS) detected in samples collected for the South Coast Interior Basins Groundwater Ambient Monitoring and Assessment (GAMA) study, California, August to December 2008.

Table 11. Species of inorganic arsenic, chromium, and iron detected in samples collected for the South Coast Interior Basins Groundwater Ambient Monitoring and Assessment (GAMA) study, California, August to December 2008.

Table 12. Results for analyses of stable isotope ratios and tritium and carbon-14 activities detected in samples collected for the South Coast Interior Basins Groundwater Ambient Monitoring and Assessment (GAMA) study, California, August to December 2008.

Table 13A. Gross alpha and gross beta radioactivity detected in samples collected for the South Coast Interior Basins Groundwater Ambient Monitoring and Assessment (GAMA) study, California, August to December 2008

Table 13B. Radon-222 detected in samples collected for the South Coast Interior Basins Groundwater Ambient Monitoring and Assessment (GAMA) study, California, August to December 2008

\section{Appendix Tables}

Table A1. Analytical methods used for the determination of organic and inorganic constituents by the U.S. Geological Survey (USGS) National Water Quality Laboratory (NWQL) and additional contract laboratories..

Table A2. Preferred analytical schedules for constituents appearing on multiple schedules, for samples collected for the South Coast Interior Basins Groundwater Ambient Monitoring and Assessment (GAMA) study, California, August to December 2008

Table A3. Constituents detected in field blanks collected for the South Coast Interior Basins Groundwater Ambient Monitoring and Assessment (GAMA) study, California, August to December 2008.

Table A4A. Quality-control summary for replicate analyses of organic constituents detected in samples collected for the South Coast Interior Basins Groundwater Ambient Monitoring and Assessment (GAMA) study, California, August to December 2008

Table A4B. Quality-control summary for replicate analyses of trace elements, major and minor ions, silica, total dissolved solids (TDS), nutrients, and isotope tracers detected in samples collected for the South Coast Interior Basins Groundwater Ambient Monitoring and Assessment (GAMA) study, California, August to 
Table A4B. Quality-control summary for replicate analyses of trace elements, major and minor ions, silica, total dissolved solids (TDS), nutrients, and isotope tracers detected in samples collected for the South Coast Interior Basins Groundwater Ambient Monitoring and Assessment (GAMA) study, California, August to December 2008.

Table A5A. Quality-control summary for matrix-spike recoveries of volatile organic compounds (VOCs) in samples collected for the South Coast Interior Basins Groundwater Ambient Monitoring and Assessment (GAMA) study, California, August to December 2008

Table A5B. Quality-control summary for matrix-spike recoveries of pesticides and pesticide degradates in samples collected for the South Coast Interior Basins Groundwater Ambient Monitoring and Assessment (GAMA) study, California, August to December 2008

Table A5C. Quality-control summary for matrix-spike recoveries of polar pesticides and metabolites in samples collected for the South Coast Interior Basins Groundwater Ambient Monitoring and Assessment (GAMA) study, California, August to December 2008

Table A5D. Quality-control summary for matrix-spike recoveries of perchlorate and $\mathrm{N}$-nitrosodimethylamine (NDMA) in samples collected for the South Coast Interior Basins Groundwater Ambient Monitoring and Assessment (GAMA) study, California, August to December 2008

Table A6. Quality-control summary for surrogate recoveries of volatile organic compounds (VOCs), pesticides and pesticide degradates, and polar pesticides and metabolites in samples collected for the South Coast Interior Basins Groundwater Ambient Monitoring and Assessment (GAMA) study, California, August to December 2008 


\section{Conversion Factors}

\section{Inch/Pound to SI}

\begin{tabular}{lll}
\hline \multicolumn{1}{r}{ Multiply } & \multicolumn{1}{c}{ By } & \multicolumn{1}{c}{ To obtain } \\
\hline foot $(\mathrm{ft})$ & 0.3048 & meter $(\mathrm{m})$ \\
mile $(\mathrm{mi})$ & 1.609 & kilometer $(\mathrm{km})$ \\
square mile $\left(\mathrm{mi}^{2}\right)$ & 2.590 & square kilometer $\left(\mathrm{km}^{2}\right)$ \\
\hline
\end{tabular}

\section{SI to Inch/Pound}

\begin{tabular}{lll}
\hline \multicolumn{1}{c}{ Multiply } & By & \multicolumn{1}{c}{ To obtain } \\
\hline meter $(\mathrm{m})$ & Length & \\
kilometer $(\mathrm{km})$ & 3.281 & foot $(\mathrm{ft})$ \\
square kilometer $\left(\mathrm{km}^{2}\right)$ & 0.6214 & mile (mi) \\
\hline
\end{tabular}

Temperature in degrees Celsius $\left({ }^{\circ} \mathrm{C}\right)$ may be converted to degrees Fahrenheit $\left({ }^{\circ} \mathrm{F}\right)$ as follows:

$$
{ }^{\circ} \mathrm{F}=\left(1.8 \times^{\circ} \mathrm{C}\right)+32
$$

Vertical coordinate information is referenced to the North American Vertical Datum of 1988 (NAVD 88).

Horizontal coordinate information is referenced to the North American Datum of 1983 (NAD 83).

Altitude, as used in this report, refers to distance above the vertical datum.

Specific conductance is given in microsiemens per centimeter at 25 degrees Celsius $(\mu \mathrm{S} / \mathrm{cm}$ at $\left.25^{\circ} \mathrm{C}\right)$.

Concentrations of chemical constituents in water are given either in milligrams per liter (mg/L) or micrograms per liter ( $\mu \mathrm{g} / \mathrm{L})$. Milligrams per liter is equivalent to parts per million (ppm) and micrograms per liter is equivalent to parts per billion (ppb). 


\title{
Abbreviations and Acronyms
}

\author{
AL-US action level (USEPA) \\ CAS Chemical Abstract Service (American Chemical Society) \\ CASRN Chemical Abstract Service (American Chemical Society) Registry Number ${ }^{\circledR}$ \\ CSU combined standard uncertainty \\ CUY Cuyama study area \\ CUYU Cuyama study area understanding (well) \\ E estimated or having a higher degree of uncertainty \\ GAMA Groundwater Ambient Monitoring and Assessment Program \\ GIL Gilroy study area \\ GILU Gilroy study area understanding (well) \\ GPS Global Positioning System \\ HAL-US lifetime health advisory level (USEPA) \\ HPLC high-performance liquid chromatography \\ LIV Livermore study area \\ LIVU Livermore study area understanding (well) \\ LRL laboratory reporting level \\ LSD land surface datum \\ LT-MDL long-term method detection level \\ MCL-US maximum contaminant level (USEPA) \\ MCL-CA maximum contaminant level (CDPH) \\ MDL method detection limit \\ MRL minimum reporting level \\ MU method uncertainty \\ $\mathrm{N}$ \\ Normal (1-gram-equivalent per liter of solution) \\ not available \\ not collected \\ nc \\ NL-CA \\ nv \\ notification level (CDPH) \\ no measured value or no value in category \\ no preference \\ np \\ NWIS \\ PCFF \\ QC \\ National Water Information System (USGS) \\ portable computer field forms program designed for USGS sampling \\ quality control \\ reporting level \\ RPD relative percent difference \\ RSD relative standard deviation \\ RSD5 risk-specific dose at $10^{-5}$ (USEPA) \\ SCl South Coast Interior Basins study unit \\ SD standard deviation \\ SMCL-CA secondary maximum contaminant level (CDPH) \\ SRL $\quad$ study reporting limit (concentration cutoff for applying the $\leq$ symbol) \\ $s s L_{c} \quad$ sample-specific critical level \\ U.S. United States \\ UV ultraviolet \\ V analyte detected in sample and associated blank, thus data are not included in ground- \\ water quality assessment \\ VPDB Vienna Pee Dee Belemnite (the international reference standard for carbon isotopes) \\ VSMOW Vienna Standard Mean Ocean Water (an isotopic water standard defined in 1968 by the \\ International Atomic Energy Agency)
}




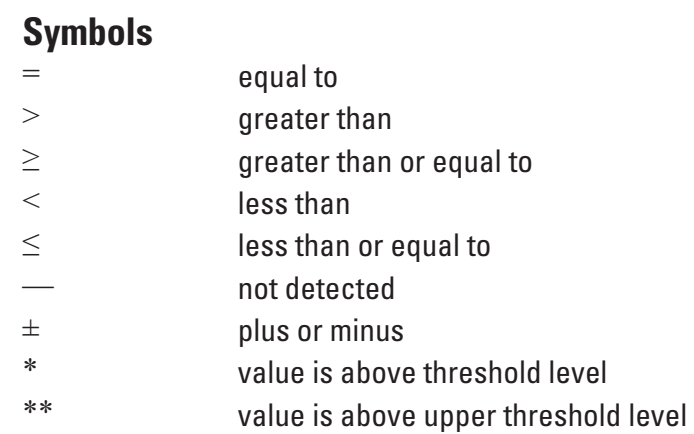

\begin{tabular}{ll}
\multicolumn{2}{l}{ Organizations } \\
CDPH & California Department of Public Health \\
CDWR & California Department of Water Resources \\
LLNL & Lawrence Livermore National Laboratory \\
NAWQA & National Water Quality Assessment (USGS) \\
NELAP & National Environmental Laboratory Accreditation Program \\
NWQL & National Water Quality Laboratory (USGS) \\
NRP & National Research Program (USGS) \\
SWRCB & State Water Resources Control Board \\
TML & Trace Metal Laboratory (USGS) \\
USEPA & U.S. Environmental Protection Agency \\
USGS & U.S. Geological Survey
\end{tabular}

\section{Selected Chemical Names}

$\begin{array}{ll}\mathrm{CaCO}_{3} & \text { calcium carbonate } \\ \mathrm{CO}_{3}{ }^{-2} & \text { carbonate } \\ \mathrm{CFC} & \text { chlorofluorocarbon } \\ \mathrm{HCl} & \text { hydrochloric acid } \\ \mathrm{HCO}_{3}^{-} & \text {bicarbonate } \\ \mathrm{MTBE}^{-} & \text {methyl tert-butyl ether } \\ \mathrm{Na}_{2} \mathrm{~S}_{2} \mathrm{O}_{3} & \text { sodium thiosulfate } \\ \mathrm{NDMA}^{-} & \text {N-nitrosodimethylamine } \\ \mathrm{NO}_{2}{ }^{-}+\mathrm{NO}_{3}{ }^{-} & \text {nitrite plus nitrate, as nitrogen } \\ \mathrm{PCE}^{\mathrm{SiO}} & \text { perchloroethene (tetrachloroethene) } \\ \mathrm{TCE} & \text { silicon dioxide } \\ \mathrm{TCP} & \text { trichloroethene } \\ \text { TDS } & \text { trichloropropane } \\ \mathrm{THM} & \text { total dissolved solids } \\ \text { VOC } & \text { trihalomethane } \\ & \text { volatile organic compound }\end{array}$

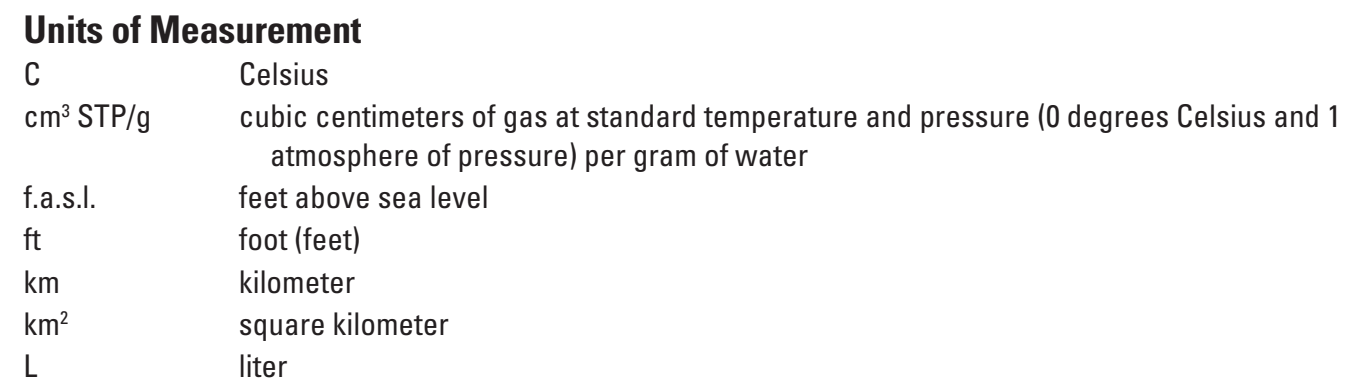




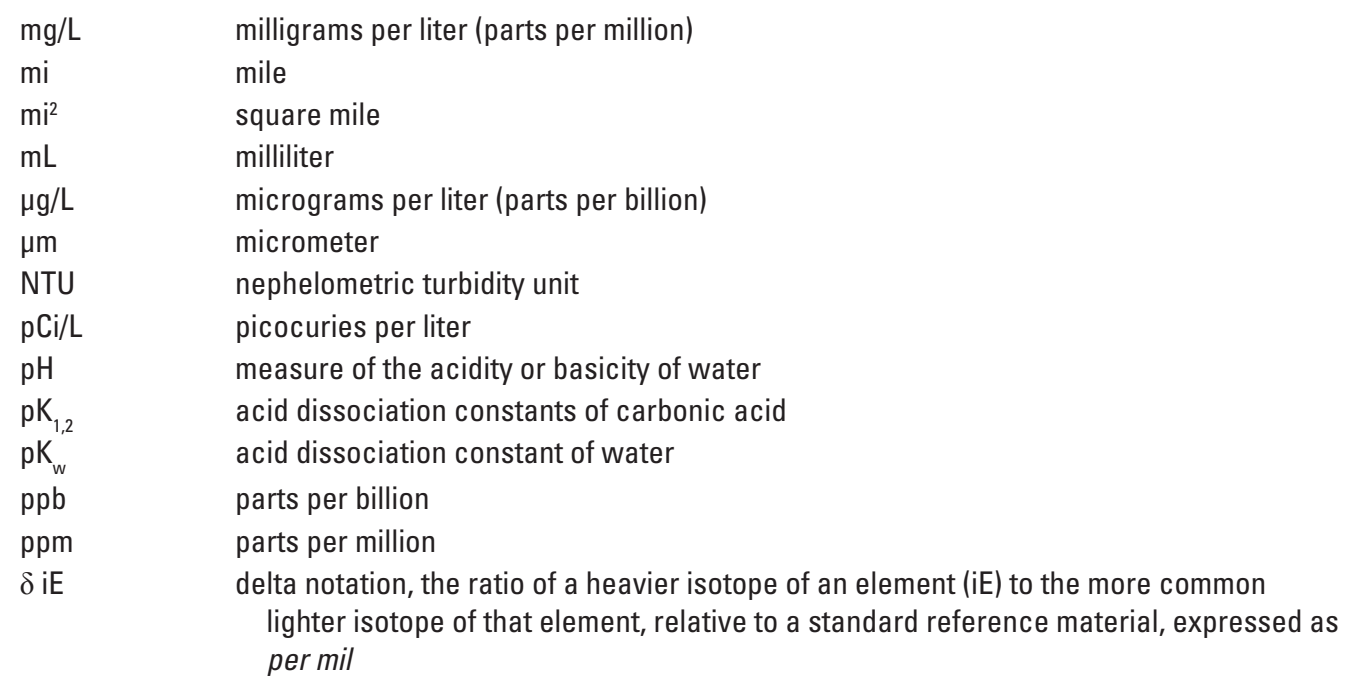


This page intentionally left blank. 


\title{
Groundwater-Quality Data in the South Coast Interior Basins Study Unit, 2008: Results from the California GAMA Program
}

\author{
By Timothy M. Mathany, Justin T. Kulongoski, Mary C. Ray, and Kenneth Belitz
}

\section{Abstract}

Groundwater quality in the approximately 653-square-mile South Coast Interior Basins (SCI) study unit was investigated from August to December 2008, as part of the Priority Basins Project of the Groundwater Ambient Monitoring and Assessment (GAMA) Program. The GAMA Priority Basins Project was developed in response to Legislative mandates (Supplemental Report of the 1999 Budget Act 1999-00 Fiscal Year and the Groundwater-Quality Monitoring Act of 2001 [Sections 10780-10782.3 of the California Water Code, Assembly Bill 599]) to assess and monitor the quality of groundwater used as public supply for municipalities in California, and is being conducted by the U.S. Geological Survey (USGS) in cooperation with the California State Water Resources Control Board (SWRCB). SCI was the 27th study unit to be sampled as part of the GAMA Priority Basins Project.

This study was designed to provide a spatially unbiased assessment of the quality of untreated groundwater used for public water supplies within SCI, and to facilitate statistically consistent comparisons of groundwater quality throughout California. Samples were collected from 54 wells within the three study areas [Livermore, Gilroy, and Cuyama] of SCI in Alameda, Santa Clara, San Benito, Santa Barbara, Ventura, and Kern Counties. Thirty-five of the wells were selected using a spatially distributed, randomized grid-based method to provide statistical representation of the study unit (grid wells), and 19 were selected to aid in evaluation of specific water-quality issues (understanding wells).

The groundwater samples were analyzed for organic constituents (volatile organic compounds [VOCs], pesticides and pesticide degradates, polar pesticides and metabolites, and pharmaceutical compounds), constituents of special interest (perchlorate and $N$-nitrosodimethylamine [NDMA]), naturally occurring inorganic constituents (trace elements, nutrients, major and minor ions, silica, total dissolved solids [TDS], and alkalinity), and radioactive constituents (gross alpha and gross beta radioactivity and radon-222). Naturally occurring isotopes (stable isotopes of hydrogen, oxygen, and carbon, and activities of tritium and carbon-14) and dissolved noble gases also were measured to help identify the sources and ages of the sampled groundwater. In total, 288 constituents and water-quality indicators (field parameters) were investigated.

Three types of quality-control samples (blanks, replicates, and matrix spikes) each were collected at approximately 4-11 percent of the wells, and the results for these samples were used to evaluate the quality of the data for the groundwater samples. Field blanks rarely contained detectable concentrations of any constituent, suggesting that contamination was not a significant source of bias in the data obtained from the groundwater samples. Differences between replicate samples generally were less than 10 percent relative standard deviation, indicating acceptable analytical reproducibility. Matrix spike recoveries were within the acceptable range (70 to 130 percent) for most compounds.

This study did not attempt to evaluate the quality of water delivered to consumers; after withdrawal from the ground, untreated groundwater typically is treated, disinfected, and/or blended with other waters to maintain water quality. Regulatory thresholds apply to water that is served to the consumer, not to untreated groundwater. However, to provide some context for the results, concentrations of constituents measured in the untreated groundwater were compared with regulatory and nonregulatory health-based thresholds established by the U.S. Environmental Protection Agency (USEPA) and California Department of Public Health (CDPH) and to nonregulatory thresholds established for aesthetic and technical concerns by CDPH. Comparisons between data collected for this study and thresholds for drinking water are for illustrative purposes only, and are not indicative of compliance or noncompliance with those thresholds.

Most inorganic constituents that were detected in groundwater samples from the 35 grid wells in the SCI study unit were found at concentrations below drinking-water thresholds; additionally, all detections of organic constituents in SCI grid well samples were below health-based thresholds. 
In total, VOCs and pesticides and pesticide degradates were detected in approximately 23 percent of the 35 grid wells sampled in the SCI study. In the Livermore study area, VOCs were detected in approximately 67 percent and pesticides and pesticide degradates were detected in 50 percent of the 6 grid wells. In the Gilroy study area, VOCs were detected in approximately 18 percent and pesticides and pesticide degradates were detected in approximately 29 percent of the 17 grid wells. In the Cuyama study area, VOCs were detected in approximately 8 percent of the grid wells, while pesticides and pesticide degradates were not detected in any of the 12 grid wells.

Trace elements and nutrients were sampled for at the 35 grid wells in the SCI study unit and most detections were below health-based thresholds. Exceptions in SCI grid wells include: two detections of arsenic above the USEPA maximum contaminant level (MCL-US) of $10 \mu \mathrm{g} / \mathrm{L}$, two detections of boron above the CDPH notification level (NL-CA) of $1,000 \mu \mathrm{g} / \mathrm{L}$, three detections of molybdenum above the USEPA lifetime health advisory level (HAL-US) of $40 \mu \mathrm{g} / \mathrm{L}$, and five detections of nitrite plus nitrate, as nitrogen $\left(\mathrm{NO}_{2}^{-}+\mathrm{NO}_{3}^{-}\right)$above the MCL-US of $10 \mathrm{mg} / \mathrm{L}$. All detections of gross alpha and gross beta radioactivity from SCI grid wells were below health-based thresholds.

Results for the nonenforceable thresholds set for aesthetic and technical concerns for trace elements, major ions, and TDS from SCI grid wells showed that 8 grid wells (of 35 sampled) had detections of manganese above the CDPH secondary maximum contaminant level (SMCL-CA) of $50 \mu \mathrm{g} / \mathrm{L}$. Twelve grid wells (of 35 sampled) had sulfate measured at a concentration above the recommended SMCL-CA threshold of $250 \mathrm{mg} / \mathrm{L}$ and 9 of these detections also were above the upper SMCL-CA threshold of $500 \mathrm{mg} / \mathrm{L}$. Twenty-five grid wells (of 35 sampled) had measured TDS concentrations above the SMCL-CA-recommended threshold of $500 \mathrm{mg} / \mathrm{L}$, and 10 of these wells also were above the SMCL-CA upper threshold of $1,000 \mathrm{mg} / \mathrm{L}$.

\section{Introduction}

Groundwater comprises nearly half of the water used for public supply in California (Hutson and others, 2004). To assess the quality of ambient groundwater in aquifers used for public supply and to establish a baseline groundwater-quality monitoring program, the State Water Resources Control Board (SWRCB), in cooperation with the U.S. Geological
Survey (USGS) and Lawrence Livermore National Laboratory (LLNL), implemented the Groundwater Ambient Monitoring and Assessment (GAMA) Program (http://www.waterboards. ca.gov/gama). The GAMA Program currently consists of three Projects: GAMA Priority Basins Project, conducted by the USGS (http://ca.water.usgs.gov/gama); GAMA Domestic Well Project, conducted by the SWRCB; and GAMA Special Studies, conducted by LLNL.

The SWRCB initiated the GAMA Priority Basins Project in response to Legislative mandates (Supplemental Report of the 1999 Budget Act 1999-2000 Fiscal Year; and, the Groundwater-Quality Monitoring Act of 2001 \{Sections 10780-10782.3 of the California Water Code, Assembly Bill 599 ) ) to assess and monitor the quality of groundwater used as public supply for municipalities in California. The GAMA Priority Basins Project is a comprehensive assessment of statewide groundwater quality designed to help better understand and identify risks to groundwater resources, and to increase the availability of information about groundwater quality to the public. For the Priority Basins Project, the USGS, in collaboration with the SWRCB, developed the monitoring plan to assess groundwater basins through direct and other statistically reliable sampling approaches (Belitz and others, 2003; State Water Resources Control Board, 2003). Key aspects of the project are inter-agency collaboration, and cooperation with local water agencies and well owners. Local participation in the project is entirely voluntary.

The GAMA Priority Basins Project is unique because it includes many chemical analyses that otherwise are not available in statewide water-quality monitoring datasets. Groundwater samples collected for the project are analyzed for 288 chemical constituents using analytical methods with much lower detection limits than required by the California Department of Public Health (CDPH). These analyses will be especially useful for providing an early indication of changes in groundwater quality. In addition, the GAMA Priority Basins Project analyzes samples for a suite of constituents more extensive than that required by $\mathrm{CDPH}$, and for a suite of chemical and isotopic tracers for exploring hydrologic and geochemical processes. A broader understanding of groundwater composition is useful for identifying the natural and human factors affecting water quality. Understanding the occurrence and distribution of chemical constituents of significance to water quality is important for the long-term management and protection of groundwater resources. 
The range of hydrologic, geologic, and climatic conditions that exist in California must be considered in an assessment of groundwater quality. Belitz and others (2003) partitioned the State into 10 hydrogeologic provinces, each with distinctive hydrologic, geologic, and climatic characteristics (fig. 1), and representative regions in all 10 provinces were included in the project design. Eighty percent of California's approximately 16,000 public-supply wells are located in groundwater basins within these hydrologic provinces. These groundwater basins, defined by the California Department of Water Resources (CDWR), generally consist of relatively permeable, unconsolidated deposits of alluvial or volcanic origin (California Department of Water Resources, 2003). Groundwater basins were prioritized for sampling on the basis of the number of public-supply wells in the basin, with secondary consideration given to municipal groundwater use, agricultural pumping, the number of formerly leaking underground fuel tanks, and pesticide applications within the basins (Belitz and others, 2003). In addition, some groundwater basins or groups of adjacent similar basins with relatively few publicsupply wells were assigned high priority so that all hydrogeologic provinces would be represented in the subset of basins sampled as part of the project. The 116 priority basins were grouped into 37 study units. Some areas not in the defined groundwater basins were included in the nearest respective study unit to achieve representation of the 20 percent of public-supply wells not located in the groundwater basins.

Three types of water-quality assessments are being conducted with the data collected in each study unit: (1) Status: assessment of the current quality of the groundwater resource; (2) Trends: detection of changes in groundwater quality; and (3) Understanding: identification of the natural and human factors affecting groundwater quality (Kulongoski and Belitz, 2004). This status report is one of a series of reports presenting water-quality data collected in each study unit (Wright and others, 2005; Bennett and others, 2006; Kulongoski and others, 2006; Fram and Belitz, 2007; Kulongoski and Belitz, 2007; Burton and Belitz, 2008; Dawson and others, 2008; Ferrari and others, 2008; Land and Belitz, 2008; Landon and Belitz, 2008; Mathany and others, 2008; Schmitt and others, 2008; Shelton and others, 2008; Fram and others, 2009; Kent and Belitz, 2009; Mathany and Belitz, 2009; Montrella and Belitz, 2009; and, Ray and others, 2009). Subsequent reports will address the trends and understanding aspects of the water-quality assessments of each study unit.
The South Coast Interior Basins GAMA study unit, hereafter referred to as $\mathrm{SCI}$, contains 11 groundwater basins and subbasins delineated by CDWR. SCI was considered high priority for sampling to provide adequate characterization of the South Coast Ranges Hydrologic Province (Belitz and others, 2003).

\section{Purpose and Scope}

The purposes of this report are to describe: (1) the study design, including the hydrogeologic setting of SCI and the study methods; (2) the results of quality-control tests; and (3) the analytical results for groundwater samples collected in SCI. Groundwater samples were analyzed for water-quality indicators (field parameters), organic and inorganic constituents, radioactive constituents, naturally occurring isotopes, and dissolved noble gases. The chemical data presented in this report were evaluated by comparison to State and Federal drinking water regulatory and other nonregulatory healthbased standards that are applied to treated drinking water. Regulatory and nonregulatory thresholds considered for this report are those established by the U.S. Environmental Protection Agency (USEPA) and/or the CDPH. The data presented in this report are intended to characterize the quality of untreated groundwater resources within the study unit, not the treated drinking water delivered to consumers by water purveyors. Discussion of the factors that influence the distribution and occurrence of the constituents detected in groundwater samples will be the subject of subsequent publications.

\section{Hydrogeologic Setting}

The South Coast Interior Basins study unit lies within the Southern Coast Ranges Hydrogeologic Province described by Belitz and others (2003), and includes 11 CDWR-defined groundwater basins and subbasins (California Department of Water Resources,2004a,b,c,d,e,f,g,h,i,j; 2006). The three study areas of the SCI study unit (Livermore, Gilroy, and Cuyama) cover an area of approximately $653 \mathrm{mi}^{2}$, in Alameda, Contra Costa, Santa Clara, San Benito, San Luis Obispo, Santa Barbara, Ventura, Kern, and Los Angeles Counties, California (fig. 2). 


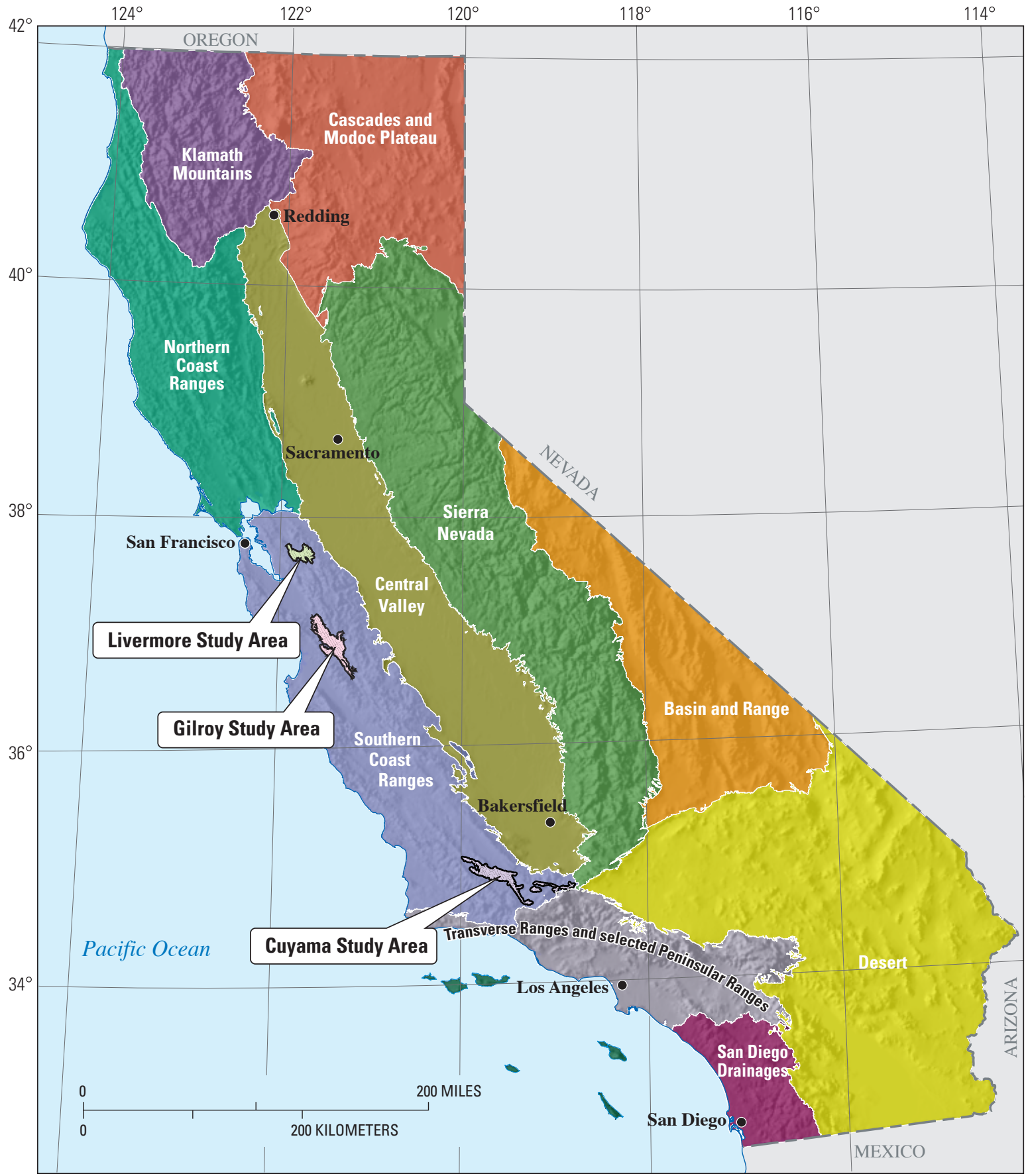

Base from U.S. Geological Survey digital elevation

Provinces from Belitz and others, 2003 data, 1999, Albers Equal Area Projection

Figure 1. The hydrogeologic provinces of California and the location of the South Coast Interior Basins Groundwater Ambient Monitoring and Assessment (GAMA) study unit. 


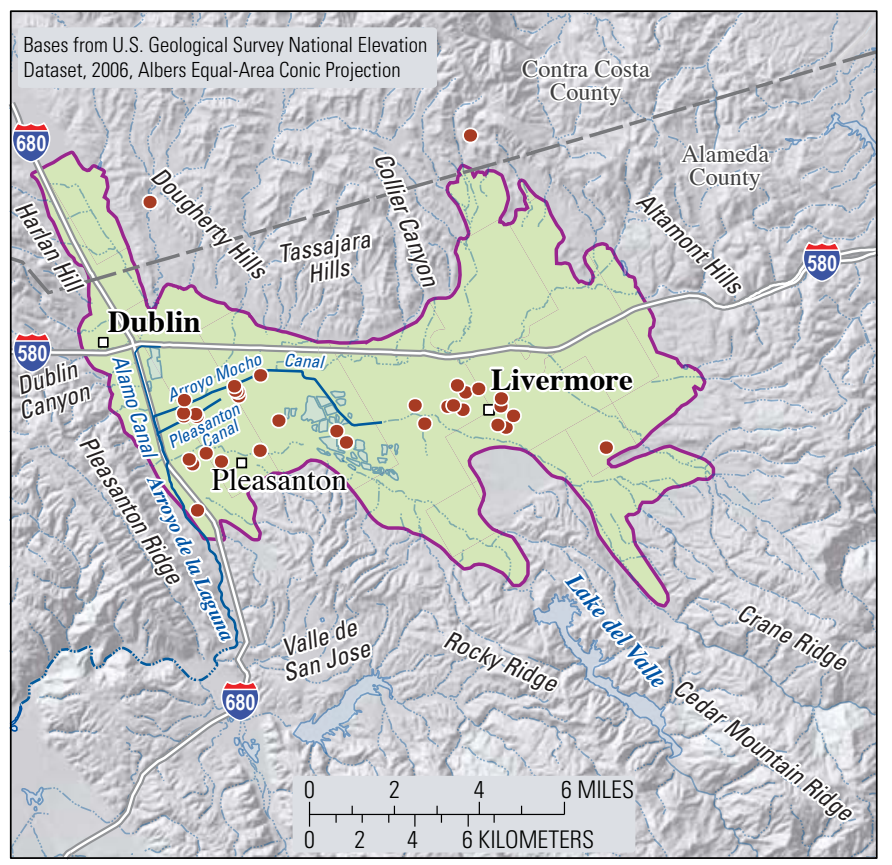

Livermore Study Area

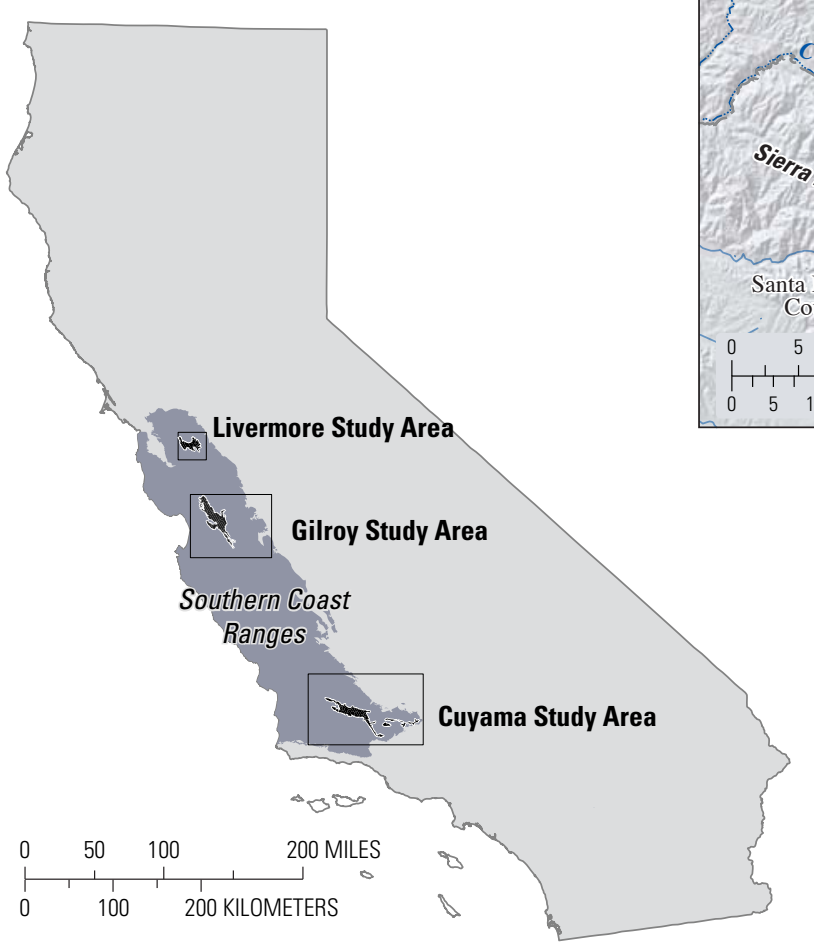

Figure 2. The South Coast Interior Basins Groundwater Ambient Monitoring and Assessment (GAMA) study unit showing the three study areas (Livermore, Gilroy, and Cuyama), the location of public-supply wells with a record in the California Department of Public Health (CDPH) Database, major cities, topographic features, and hydrologic features.

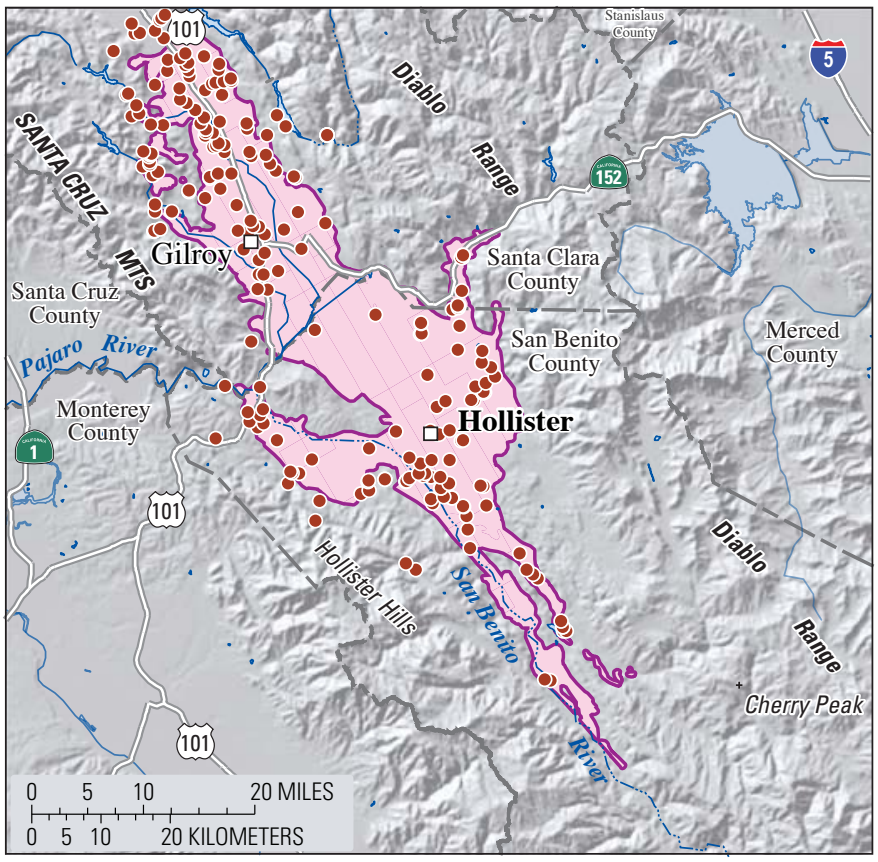

Gilroy Study Area

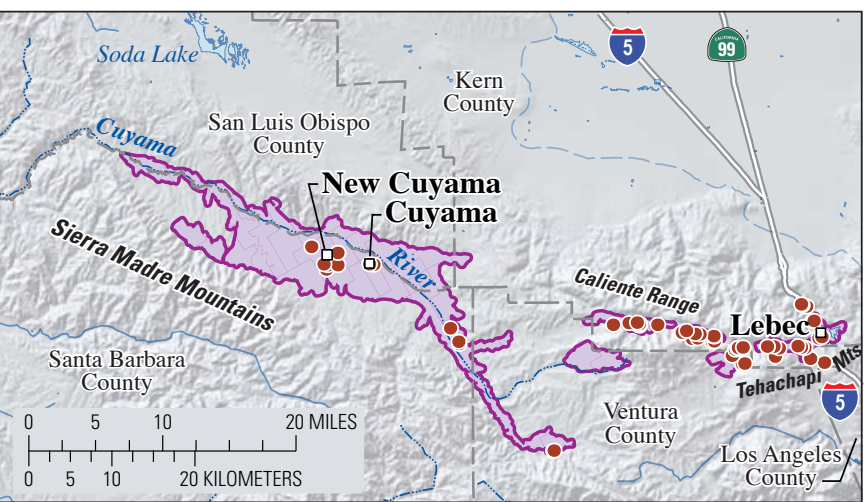

Cuyama Study Area

\section{EXPLANATION}

__ Groundwater basin (from California Department of Water Resources, CDWR)

- Public-supply well-With a record in California Department of Public Health (CDPH) Database 
The Livermore (LIV) study area is approximately $109 \mathrm{mi}^{2}$ in area and lies about $40 \mathrm{mi}$ east of San Francisco within a structural trough of the Diablo Range. The LIV study area is located within the Livermore Valley Groundwater Basin (California Department of Water Resources, 2006), and is bounded on the west by the Pleasanton Ridge, Dublin Canyon, and Harlan Hill. It is bordered to the north by the Dougherty and Tassajara Hills, Collier Canyon, and the Contra Costa County boundary. The eastern boundary of the study area is the Altamont Hills. The southernmost border of LIV includes: the Crane, Cedar Mountain, and Rocky Ridges, Lake del Valle, and Valle de San Jose. The main surface drainage features of the LIV study area include four major canals, the Alamo, Arroyo Mocho, and Pleasanton, which converge to form the Arroyo de la Laguna canal on the west side of the basin (fig. 3). Elevations within LIV range from about $280 \mathrm{ft}$ above sea level (f.a.s.l.) in the southwest, where Arroyo de la Laguna exits the study area, to about 600 f.a.s.1. in the east, near the Altamont Hills. Average annual precipitation in LIV ranges from more than 20 inches along the southeast and northwest study area margins to 16 inches on the valley floor (California Department of Water Resources, 2006).

Primary water-bearing formations in the LIV study area occur in the Livermore Valley and portions of the upland areas surrounding the valley. These formations include Holocene age valley-fill materials, the Plio-Pleistocene age Livermore Formation in the south and southwest, and the Pliocene-age Tassajara Formation in the northern region of LIV (California Department of Water Resources, 2006).

The LIV study area has three major faults (the Pleasanton, Parks, and Livermore fault zone), each acting as a barrier to the lateral movement of groundwater (California Department of Water Resources, 2006) (fig. 3). Groundwater recharge in LIV occurs from a mixture of ambient recharge (percolation of precipitation and irrigation waters), subsurface inflow, and engineered recharge (percolation ponds and lakes) (California Department of Water Resources, 2006).

The Gilroy (GIL) study area is approximately $287 \mathrm{mi}^{2}$ in area and lies within the Gilroy-Hollister Groundwater Basin, which contains four CDWR-defined subbasins: Llagas, Bolsa Area, Hollister Area, and San Juan Bautista Area (not shown in figure 4) (California Department of Water Resources, 2004a,b,c,d). The GIL study area is bordered on the west by the San Andreas Rift Zone, the Hollister Hills, and the Santa Cruz Mountains. It is bounded in the north, east, and south by the Diablo Range. The Pájaro River and its major tributaries (Llagas and Uvas Creeks) drain the northern portion of GIL to the Pacific Ocean through Monterey Bay. The southern portion of the GIL study area is drained by the San Benito River and its major tributaries (Tres Pinos and Pescadero Creeks) (fig. 4). Elevations within the basin range from about 140 f.a.s.1 in the north, along the Santa Clara County and San Benito County border, to approximately 2,400 f.a.s.1. in the south, near Cherry Peak, in the Diablo Range. Average annual precipitation in GIL ranges from 17 inches in the northern reaches of the study area to 13 inches in the south (California Department of Water Resources, 2004a,b,c,d).

The primary water-bearing formation in GIL is a sedimentary sequence consisting mainly of clays, silts, sands, and gravels ranging in age from Tertiary to Holocene (California Department of Water Resources, 2004a,b,c,d). The major faults that bound the GIL study area (Calaveras, San Andreas, and Sargent) are relatively impermeable barriers to groundwater flow (California Department of Water Resources, $2004 b, c, d)$. There also is an unnamed clay confining layer in the Llagas Subbasin that restricts groundwater flow in the northern region of GIL (California Department of Water Resources, 2004a).

Groundwater recharge in the GIL study area occurs from a variety of sources: ambient recharge (infiltration losses along the Pájaro and San Benito Rivers and their tributaries, percolation of precipitation and irrigation waters, and seepage along canals), subsurface inflow, and engineered recharge. A number of engineered-recharge facilities (percolation ponds and channels) enhance ambient recharge to the northern portion of GIL. In the southern region of the GIL study area, engineered recharge occurs from the San Benito River as a result of river regulation at the Hernandez Reservoir, which is located approximately $20 \mathrm{mi}$ southeast of the study area boundary (California Department of Water Resources, 2004a,b,c,d) (fig. 4).

The Cuyama (CUY) study area is approximately $257 \mathrm{mi}^{2}$ in area, comprised largely of the Cuyama Valley Groundwater Basin $\left(230 \mathrm{mi}^{2}\right)$, but also includes five small CDWR-defined groundwater basins [Castaic Lake Valley $\left(6 \mathrm{mi}^{2}\right)$, Cuddy Canyon Valley $\left(5 \mathrm{mi}^{2}\right)$, Cuddy Ranch Area $\left(7 \mathrm{mi}^{2}\right)$, Cuddy Valley $\left(5 \mathrm{mi}^{2}\right)$, and Mil Potrero $\left(4 \mathrm{mi}^{2}\right)$ ] (California Department of Water Resources, 2004e,f,g,h,i,j). The CUY study area is bounded on the west and the south by the Sierra Madre Mountains and on the north and east by the Caliente Range. The study area is drained by the Cuyama River and its major tributaries (Alamo and Reyes Creeks and the New River) (fig. 5). Elevations within CUY range from about 1,400 f.a.s.1. in the west, where the Cuyama River exits the Cuyama study unit, to about 6,400 f.a.s.1. in the east, in the Tehachapi Mountains. Average annual precipitation in the CUY study area ranges from 15 inches in the southern mountains to 7 inches in the north (California Department of Water Resources, 2004e).

The primary water-bearing formations in CUY mainly are unconfined and are composed of Holocene age alluvium (consisting of alternating layers of sands, gravels, silts, and clays) and older terrestrial deposits (consisting of Pleistoceneaged poorly consolidated clays, silts, and gravels) (California Department of Water Resources, 2004e). Groundwater flow in the Cuyama Valley groundwater basin is controlled by a series of small faults (Morales, Ozena, and South Cuyama), which act as barriers to groundwater movement. Groundwater recharge in CUY occurs almost exclusively from seepage from the Cuyama River (California Department of Water Resources, 2004e). 

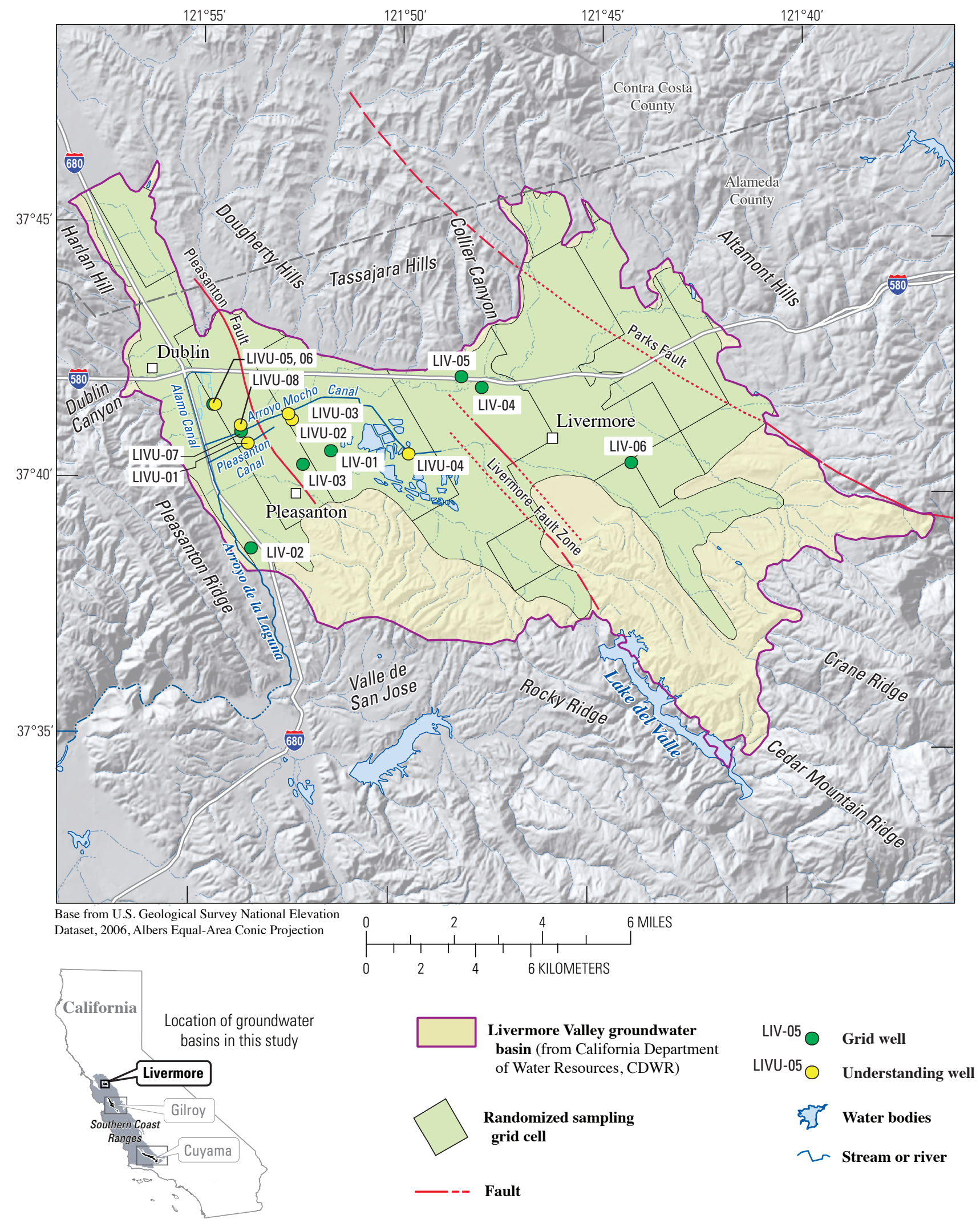

Figure 3. The South Coast Interior Basins Groundwater Ambient Monitoring and Assessment (GAMA) study unit showing the distribution of the Livermore study-area grid cells, the location of sampled grid wells and understanding wells, the Livermore Valley groundwater-basin boundary (as defined by the California Department of Water Resources, CDWR), major cities, major roads, topographic features, and hydrologic features. Alphanumeric identification numbers for grid wells have the prefix “LIV", and understanding wells have "LIVU." 


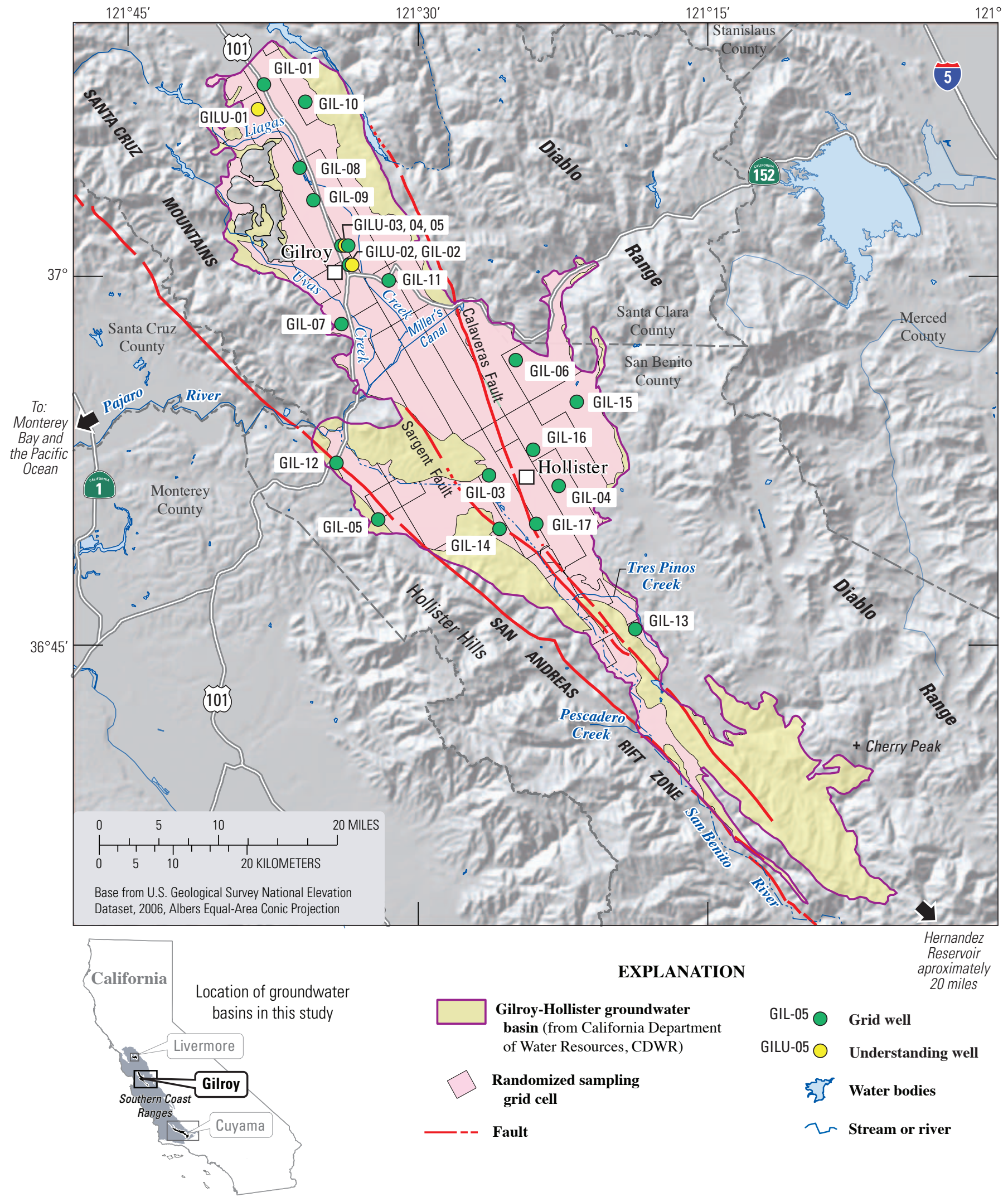

Figure 4. The South Coast Interior Basins Groundwater Ambient Monitoring and Assessment (GAMA) study unit showing the distribution of the Gilroy study-area grid cells, the location of sampled grid wells and understanding wells, the Gilroy-Hollister groundwater-basin boundary (as defined by the California Department of Water Resources, CDWR), major cities, major roads, topographic features, and hydrologic features. Alphanumeric identification numbers for grid wells have the prefix "GIL", and understanding wells have "GILU." 


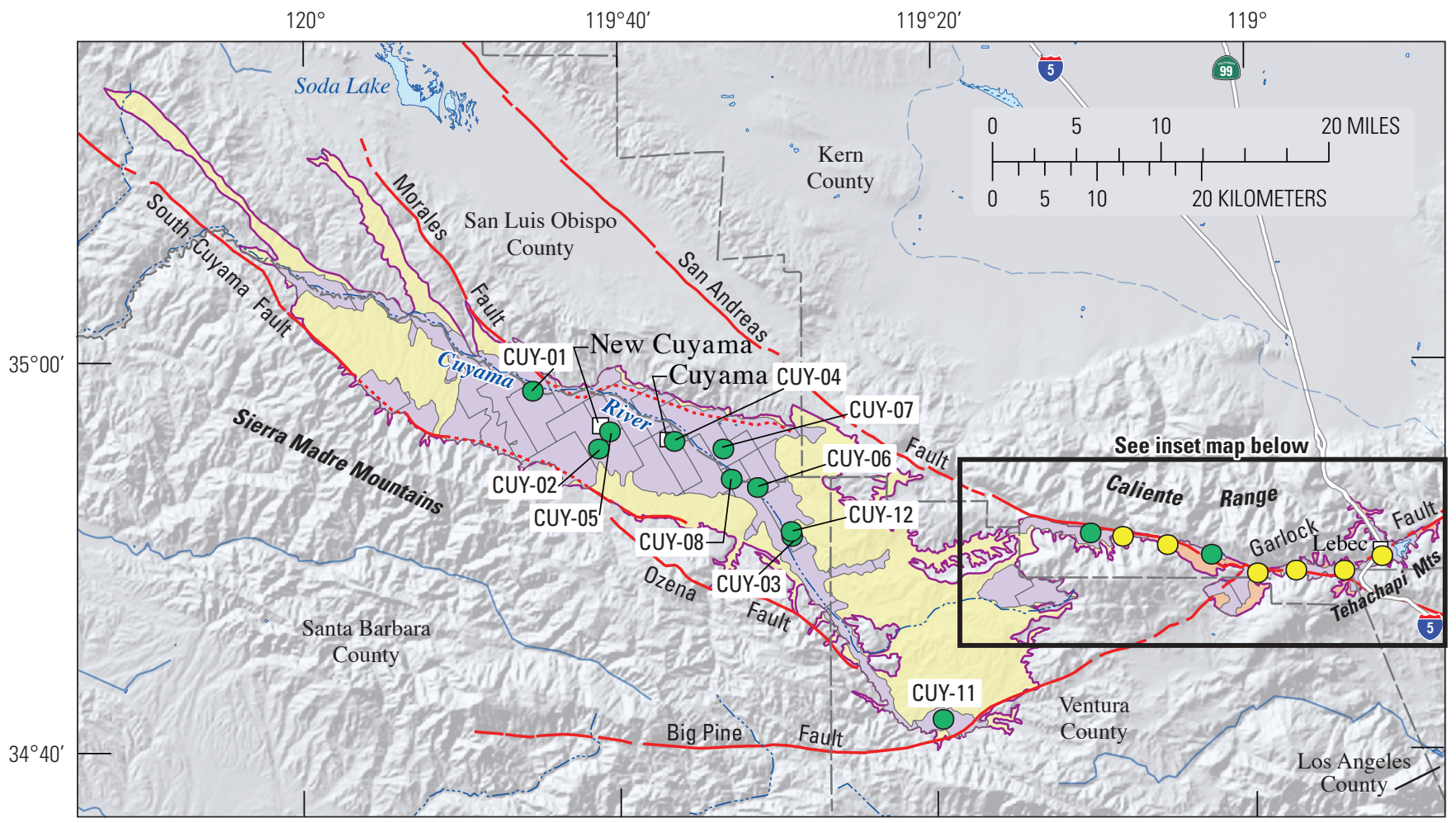

Base from U.S. Geological Survey National Elevation Dataset, 2006, Albers Equal-Area Conic Projection

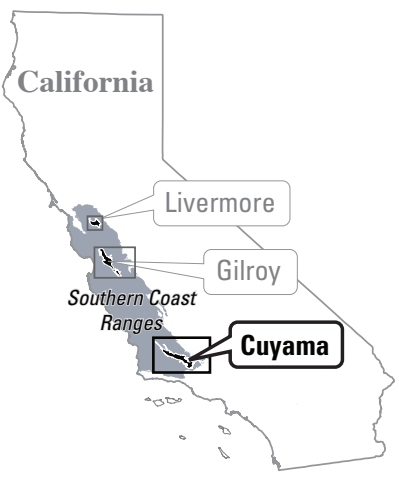

Location of groundwater basins in this study

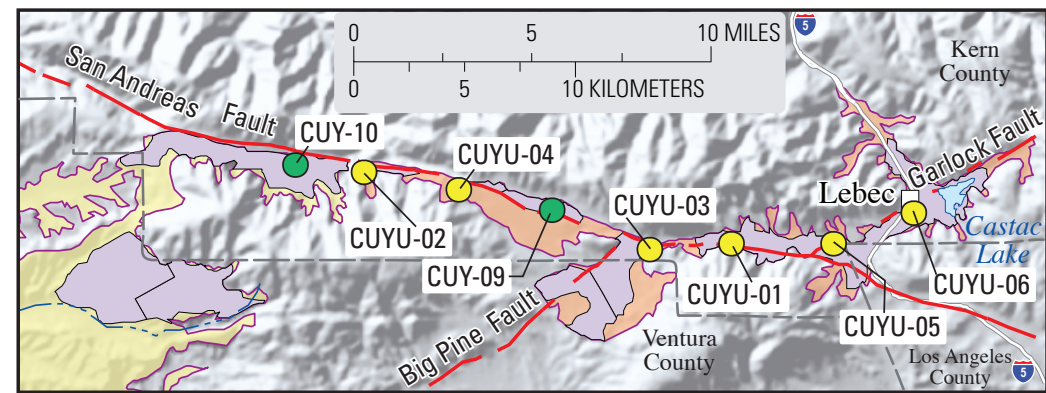

EXPLANATION

Cuyama Valley groundwater

basin (from California Department of Water Resources, CDWR

Castaic Lake Valley, Cuddy Canyon Valley, Cuddy Ranch Area, Cuddy Valley, and Mil Potrero groundwater basins included in this study (from California Department of Water Resources, CDWR)

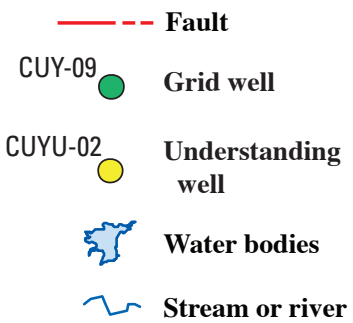

\section{Randomized sampling} grid cell

Figure 5. The South Coast Interior Basins Groundwater Ambient Monitoring and Assessment (GAMA) study unit showing the distribution of the Cuyama study-area grid cells, the location of sampled grid wells and understanding wells, the Cuyama Valley, Castaic Lake Valley, Cuddy Canyon Valley, Cuddy Ranch Area, Cuddy Valley, and Mil Potrero groundwater-basin boundaries (as defined by the California Department of Water Resources, CDWR), major cities, major roads, topographic features, and hydrologic features. Alphanumeric identification numbers for grid wells have the prefix "CUY", and understanding wells have "CUYU." 
Five small CDWR-defined groundwater basins (Castaic Lake Valley, Cuddy Canyon Valley, Cuddy Ranch Area, Cuddy Valley, and Mil Potrero) located east of the Cuyama Valley groundwater basin were included in the CUY study area to gain information on the quality of groundwater in active fault zones (the Big Pine, Garlock, and San Andreas) (fig. 5, inset map). These groundwater basins lie in the Tehachapi Mountains, contain Tertiary, Pleistocene, or Quaternary-aged alluvial fill material, and are drained by a series of streams and creeks. Groundwater recharge in these basins occurs from the percolation of precipitation, spring flows, and septic tank effluent (California Department of Water Resources, 2004f,g,h,i,j).

\section{Methods}

Methods used for the GAMA Priority Basins Project were selected to achieve the following objectives: (1) design a sampling plan for suitable statistical representation; (2) collect samples in a consistent manner; (3) analyze samples using proven and reliable laboratory methods; (4) assure the quality of the groundwater data; and (5) maintain data securely and with relevant documentation. The Appendix to this report contains detailed descriptions of the sample-collection protocols and analytical methods, the quality-assurance plan, and the results of analyses of quality-control samples.

\section{Study Design}

The wells selected for sampling in this study reflect the combination of two well-selection strategies. Thirty-five "grid" wells were selected to provide a statistically unbiased, spatially distributed assessment of the quality of groundwater resources used for public drinking-water supply, while 19 additional "understanding" wells were selected to provide greater sampling density in several areas to aid in the understanding of specific groundwater-quality issues in the study areas.

The spatially distributed wells were selected using a randomized grid-based method (Scott, 1990). The randomized grid-based method divides the study unit into equal area grid cells; however, geographic features may force a grid cell to be divided into multiple pieces in order to obtain the designated coverage area for each cell. For instance, a portion of a grid cell may be located on either side of a mountain range, but the grid cell still is considered one grid cell. The objective for the SCI study unit within the GAMA South Coast Ranges Hydrologic Province was to sample at least one well per $10 \mathrm{mi}^{2}$ (about $25 \mathrm{~km}^{2}$ ). SCI was subdivided into 44 grid cells
(LIV study area, 7 grid cells; GIL study area, 19 grid cells; CUY study area, 18 grid cells) (figs. 3,4,5). If a grid cell contained more than one public-supply well, each well randomly was assigned a rank. The highest ranking well that met basic sampling criteria (for example, sampling point located prior to treatment or capability to pump for several hours), and for which permission to sample could be obtained, was sampled. If a grid cell contained no accessible public-supply wells, then other types of wells, such as domestic or irrigation wells, were considered for sampling. An attempt was made to select "alternative" wells that had depths and screened intervals similar to those in public-supply wells in the area. In this fashion, one well was selected in each cell to provide a spatially distributed, randomized monitoring network. Wells sampled as part of the spatially distributed, randomized grid-cell network, hereafter, are referred to as "grid wells." The 35 grid wells sampled in SCI were named for the study area where they were located by using the prefix "LIV", "GIL", or "CUY" and numbered in the order of sample collection within each study area (figs. 3,4,5).

Nineteen additional, nonrandomized wells were sampled throughout the three study areas of SCI to collect more information for various water-quality issues within each study area. Wells sampled as part of these studies were not included in the statistical characterization of water quality in SCI because inclusion of these wells would lead to the overrepresentation of some cells. These additional, nonrandomized wells were named for the study area where they were located by using the prefix "LIVU", "GILU", or "CUYU" ("U" indicating "understanding") and numbered in the order of sample collection within each study area (figs. 3,4,5).

The GAMA alphanumeric identification number for each well, along with the date sampled, sampling schedule, well elevation, well type, and available well-construction information is shown in table 1 (all tables shown in back of report). Groundwater samples were collected from 31 public-supply wells, 8 domestic wells, 7 irrigation wells, 7 monitoring (observation) wells, and 1 well used for industrial activities, during the period from August to December 2008.

Well locations and identifications were verified using global positioning system (GPS), 1:24,000-scale USGS topographic maps, comparison with existing well information in USGS and CDPH Databases, and information provided by well owners. Driller's logs for wells were obtained, when available. Well information was recorded by hand on field sheets and electronically on field laptop computers using the portable computer field forms (PCFF) program designed for USGS sampling. All information was verified and then uploaded into the USGS National Water Information System (NWIS). Well owner information is confidential. 
The wells in SCI were sampled using a tiered analytical approach. All wells were sampled for a standard set of constituents, including volatile organic compounds (VOCs), pesticides and pesticide degradates, perchlorate, trace elements, nutrients, major and minor ions, silica, total dissolved solids (TDS), alkalinity, stable isotopes of hydrogen and oxygen in water, tritium, dissolved noble gases, stable isotopes of carbon, and carbon-14 abundance. The standard set of constituents was termed the "fast" schedule (table 2). Wells on the "slow" schedule were sampled for all the constituents on the fast schedule, plus polar pesticides and metabolites, pharmaceutical compounds, $N$-nitrosodimethylamine (NDMA), arsenic, chromium, and iron speciation, and gross alpha and gross beta radioactivity (table 2). There also were five wells on the fast schedule (one grid and four understanding wells) for which radon-222 was added to the sampling schedule; this addition coincided with a special study being conducted in the GIL study area. Fast and slow refer to the time required to sample the well for all the analytes on the schedule. Generally, two slow or three fast wells could be sampled in 1 day. In SCI, 43 of the wells were sampled on the fast schedule (28 grid and 15 understanding wells) and 11 wells were sampled on the slow schedule (7 grid and 4 understanding wells) (table 1).

\section{Sample Collection and Analysis}

Samples were collected in accordance with the protocols established by the USGS National Water Quality Assessment (NAWQA) program (Koterba and others, 1995) and the USGS National Field Manual (U.S. Geological Survey, variously dated). These sampling protocols ensure that representative samples of groundwater are collected at each site and that the samples are collected and handled in ways that minimize the potential for contamination.

Tables $3 A-K$ list the compounds analyzed in each constituent class. Groundwater samples were analyzed for 85 VOCs (table $3 A$ ); 63 pesticides and pesticide degradates (table $3 B$ ); 60 polar pesticides and metabolites (table $3 \mathrm{C}$ ); 14 pharmaceutical compounds (table $3 D) ; 2$ constituents of special interest (table 3E); 24 trace elements (table $3 F$ ); 5 nutrients (table $3 G$ ); 9 major and minor ions, silica, TDS, and alkalinity (table 3H); arsenic, chromium, and iron species (table 3I); stable isotopes of hydrogen, oxygen, and carbon, and 5 radioactive constituents, including carbon-14 (table 3J); and 5 dissolved noble gases, tritium, and helium stable isotope ratios (table $3 K$ ). The methods used for sample collection and analysis are described in the Appendix section of this report "Sample Collection and Analysis."

\section{Data Reporting}

The methods and conventions used for reporting the data are described in the Appendix section "Data Reporting." Eleven constituents analyzed in this study were measured by more than one analytical schedule or more than one laboratory.
Four constituents analyzed in this study were measured by more than one method at the USGS National Water Quality Laboratory (NWQL), but only the results from the preferred method are reported (see Appendix section "Constituents on Multiple Analytical Schedules"). Four other constituentsarsenic, chromium, and iron concentrations and tritium activities - were measured by two different laboratories, and both sets of results are reported for these constituents.

\section{Quality Assurance}

The quality-assurance and quality-control procedures used for this study followed the protocols used by the USGS NAWQA program (Koterba and others, 1995) and described in the USGS National Field Manual (U.S. Geological Survey, variously dated). The quality-assurance plan followed by the USGS National Water Quality Laboratory (NWQL), the primary laboratory used to analyze samples for this study, is described in Maloney (2005) and Pirkey and Glodt (1998). Quality-control (QC) samples collected in the SCI study include: field blanks, replicates, and matrix and surrogate spikes. QC samples were collected to evaluate potential contamination, as well as bias and variability of the data that may have resulted from sample collection, processing, storage, transportation, and laboratory analysis. Quality-control procedures and quality-control sample results are described in the Appendix section "Quality Assurance."

\section{Water-Quality Results}

\section{Quality-Control Results}

Results of quality-control analyses (blanks, replicates, matrix spikes, and surrogates) were used to evaluate the quality of the data for the groundwater samples. On the basis of detections in field blanks collected for this and previous GAMA Priority Basins Project study units, some detections reported by the laboratory for two organic compounds were considered suspect and, therefore, were removed from the set of groundwater-quality data presented in this report (see table $A 3$ and additional discussion in Appendix). Results from the replicates confirm that the procedures used to collect and analyze the samples were consistent. Ninety-eight percent of the replicate pairs for constituents detected in samples had variability within acceptable limits. Median matrix-spike recoveries for 40 of the 210 organic constituents analyzed were lower than the acceptable limits (tables $3 B$ and $3 C$ ), which may indicate that these constituents might not have been detected in some samples if they were present in the samples at concentrations near the laboratory reporting levels (LRLs). The quality-control results are described in the Appendix section "Quality-Control Results." 


\section{Comparison Thresholds}

Concentrations of constituents detected in groundwater samples were compared with CDPH and USEPA regulatory and nonregulatory drinking-water health-based thresholds and thresholds established for aesthetic purposes (California Department of Public Health, 2008a,b; U.S. Environmental Protection Agency, 2008a,b,c). The chemical data presented in this report are meant to characterize the quality of the untreated groundwater resources within SCI, and are not intended to represent the treated drinking water delivered to consumers by water purveyors. The chemical composition of treated drinking water may differ from untreated groundwater because treated drinking water may be subjected to disinfection, filtration, mixing with other waters, and/or exposure to the atmosphere prior to its delivery to consumers. Comparisons of untreated groundwater to thresholds are for illustrative purposes only and are not indicative of compliance or noncompliance with drinking-water regulations.

The following thresholds were used for comparisons:

- MCL-Maximum Contaminant Level. Legally enforceable standards that apply to public water systems and are designed to protect public health by limiting the levels of contaminants in drinking water. MCLs established by the USEPA are the minimum standards with which states are required to comply, and individual states may choose to set more stringent standards. CDPH has established MCLs for additional constituents not regulated by the USEPA and has lowered the threshold concentration for a number of constituents with MCLs established by the USEPA. In this report, a threshold set by the USEPA and adopted by CDPH is labeled "MCL-US", and one set by CDPH that is more stringent than the MCL-US is labeled "MCLCA." CDPH is notified when constituents are detected at concentrations greater than MCL-US or MCL-CA thresholds in samples collected for the GAMA Priority Basins Project, but these detections do not constitute violations of $\mathrm{CDPH}$ regulations.

- AL-Action Level. Legally enforceable standards that apply to public water systems and are designed to protect public health by limiting the levels of copper and lead in drinking water. Detections of copper or lead above the action-level thresholds trigger requirements for mandatory water treatment to reduce the corrosiveness of water to water pipes. The action levels established by the USEPA and CDPH are the same, thus, the thresholds are labeled "AL-US" in this report.

- SMCL-Secondary Maximum Contaminant Level. Nonenforceable standards applied to constituents that affect the aesthetic qualities of drinking water, such as taste, odor, and color, or the technical qualities of drinking water, such as scaling and staining. Both the USEPA and CDPH define SMCLs, but unlike MCLs, SMCLs established by CDPH are not required to be as stringent as those established by USEPA. SMCLs established by CDPH are used in this report (SMCLCA) for all constituents that have SMCL-CA values. The SMCL-US is used for $\mathrm{pH}$ because no SMCL-CA has been defined.

- NL-Notification Level. Health-based notification levels established by CDPH for some of the constituents in drinking water that lack MCLs (NL-CA). If a constituent is detected above its NL-CA, California state law requires timely notification of local governing bodies and recommends consumer notification.

- HAL_Lifetime Health Advisory Level. The maximum concentration of a constituent at which its presence in drinking water is not expected to cause any adverse carcinogenic effects for a lifetime of exposure. HALs are established by the USEPA (HALUS) and are calculated assuming consumption of $2 \mathrm{~L}$ (2.1 quarts) of water per day over a 70 -year lifetime by a 70-kilogram (154-pound) adult and that 20 percent of a person's exposure comes from drinking water.

- RSD5-Risk-Specific Dose. The concentration of a constituent in drinking water corresponding to an excess estimated lifetime cancer risk of 1 in 100,000. RSD5 is an acronym for risk-specific dose at $10^{-5}$. RSD5s are calculated by dividing the $10^{-4}$ cancer risk concentration established by the USEPA by ten (RSD5-US).

For constituents with MCLs, detections in groundwater samples were compared to the MCL-US or MCL-CA. Constituents with SMCLs were compared with the SMCL-CA. For chloride, sulfate, specific conductance, and total dissolved solids, CDPH defines a "recommended" and an "upper" SMCL-CA; detections of these constituents in groundwater samples were compared with both levels. The SMCL-US for these constituents corresponds to the recommended SMCLCA. Detected concentrations of constituents that lack an MCL or SMCL were compared to the NL-CA. For constituents that lack an MCL, SMCL, or NL-CA, detected concentrations were compared with the HAL-US. For constituents that lack an MCL, SMCL, NL-CA, or HAL-US, detected concentrations were compared with the RSD5-US. Note that if a constituent has more than one type of established threshold, using this hierarchy to select the comparison threshold will not necessarily result in selection of the threshold with the lowest concentration. For example, zinc has an SMCL-CA of 5,000 $\mu \mathrm{g} / \mathrm{L}$ and a HAL-US of 2,000 $\mu \mathrm{g} / \mathrm{L}$, and the comparison threshold selected by this hierarchy is the SMCL-CA. The comparison thresholds used in this report are listed in tables $3 A-3 K$ for all constituents and in tables 4-13 for constituents detected in groundwater samples from SCI. Not all constituents analyzed for this study have established thresholds available. Detections of constituents at concentrations greater than the selected comparison threshold are marked with asterisks in tables 4, 5, and $7-11$. 


\section{Groundwater-Quality Data}

Results from analyses of untreated groundwater samples from SCI are presented in tables 4-13. These results are separated into the three study areas that make up the SCI study unit (LIV, GIL, and CUY). Groundwater samples collected in SCI were analyzed for 288 constituents, and 219 of those constituents were not detected in any of the samples (tables $3 A-K$ ). For organic constituent classes that were analyzed at all of the grid wells, the results tables include the following summary statistics for all 35 SCI grid wells, and for the grid wells in each study area (LIV, GIL, and CUY), the number of wells at which each analyte was detected, the frequency at which it was detected (in relation to the number of grid wells in the study area), and the total number of constituents detected at each well. For the constituents of special interest, inorganic, isotopic, and radioactive constituent classes, the summary tables include all wells, constituents, and samples analyzed. Results from the understanding wells are presented in the tables, but these results were excluded from the detection frequency calculations to avoid statistically over-representing the areas in the vicinity of the understanding wells.

Table 4 includes water-quality indicators (field parameters) measured in the field and at the NWQL. Tables 5-13 present the results of groundwater analyses organized by compound classes:

- Organic constituents

- Volatile organic compounds (VOCs) (table 5)

- Pesticides and pesticide degradates (table 6A)

- Polar pesticides and metabolites (table 6B)

- Constituents of special interest (table 7)

- Inorganic constituents

- Trace elements (table 8)

- Nutrients (table 9)

- Major and minor ions, silica, and total dissolved solids (TDS) (table 10)

- Arsenic, chromium, and iron speciation (table 11)

- Isotopic tracers (table 12)

- Radioactive constituents (tables 13A,B)

Results for pharmaceutical compounds are not presented in this report; they will be included in a subsequent publication. In addition, as of the publishing date of this data report, the results of analyses of samples collected in SCI for noble gases and helium isotope ratios were not available; results will be presented in a subsequent publication.

\section{Water-Quality Indicators (Field Parameters)}

Field and laboratory measurements of dissolved oxygen, $\mathrm{pH}$, specific conductance, alkalinity, and associated parameters (turbidity, water temperature, and bicarbonate and carbonate concentrations) are presented in table 4. Alkalinity, dissolved oxygen, and bicarbonate and carbonate concentrations are used as indicators of natural processes that affect water chemistry. Specific conductance is the measure of electrical conductivity of the water, and is proportional to the amount of total dissolved solids (TDS) in the water. The $\mathrm{pH}$ value indicates the acidity of the water.

Sixty percent of SCI's grid wells ( 21 of 35 wells) ( 2 of 6 LIV grid wells, 9 of 17 GIL grid wells, and 10 of 12 CUY grid wells) had field specific conductance values above the recommended SMCL-CA of $900 \mu \mathrm{S} / \mathrm{cm}$; 9 of these grid wells (3 GIL wells and 6 CUY wells) also were above the upper threshold of $1,600 \mu \mathrm{S} / \mathrm{cm}$.

Nine of the 19 understanding wells (6 of 8 LIVU wells and 3 of 6 CUYU wells) had field specific conductance values above the recommended SMCL-CA. Additionally, 4 of the 8 LIVU wells were above the SMCL-CA upper threshold.

None of the 54 wells sampled in the SCI study unit had field $\mathrm{pH}$ values outside of the SMCL-US range for $\mathrm{pH}$ (table 4). (Laboratory $\mathrm{pH}$ values may be dissimilar to field $\mathrm{pH}$ values because the $\mathrm{pH}$ of groundwater may change upon exposure to the atmosphere [see Appendix]).

\section{Organic Constituents}

Volatile organic compounds (VOCs) may be present in paints, solvents, fuels, fuel additives, refrigerants, fumigants, and disinfected water, and are characterized by their tendency to evaporate. VOCs generally persist longer in groundwater than in surface water because groundwater is isolated from the atmosphere.

Of the 85 VOCs analyzed, 13 were detected in SCI groundwater samples; all detections were below health-based thresholds (table 5). VOCs that were detected in more than 10 percent of the six LIV grid wells were: chloroform (trichloromethane); dichlorodifluoromethane (CFC-12); perchloroethene (PCE, tetrachloroethene); 1,1-dichloroethene (1,1-DCE); methyl ethyl ketone (2-butanone, MEK); carbon tetrachloride (tetrachloromethane); and tetrahydrofuran. No VOCs were detected in more than 10 percent of the 17 GIL grid wells or the 12 CUY grid wells. One or more VOCs were detected in 8 of the 35 grid wells in SCI and in 8 of the 19 understanding wells sampled. 
Pesticides include herbicides, insecticides, and fungicides, and are used to control weeds, insects, fungi, and other pests in agricultural, urban, and suburban settings. Of the 63 pesticides and pesticide degradates analyzed at all of the grid and understanding wells in the SCI study, 4 pesticides were detected in groundwater samples; all detections were below health-based thresholds (table 6A). The herbicides-simazine, deethylatrazine (a degradate of atrazine), prometon, and/or tebuthiuron-were detected in more than 10 percent of the six LIV grid well samples. Simazine and deethylatrazine are among the nation's most commonly detected pesticide compounds in groundwater (Gilliom and others, 2006). Simazine was detected in more than 10 percent of the 17 GIL grid well samples. No pesticides and pesticide degradates were detected in any of the 12 grid wells in the CUY study area. One or more pesticide compounds were detected in 8 of the 35 grid wells in SCI and in 3 of the 19 understanding wells sampled.

In addition, groundwater samples for 60 polar pesticides and metabolites were collected at the 11 slow wells in SCI. Of the 60 polar pesticides and metabolites analyzed, only bentazon (an herbicide) was detected (table 6B). This single detection occurred in a LIV study area grid well (LIV-06), and it was below the health-based threshold.

\section{Constituents of Special Interest}

Perchlorate and NDMA are constituents of special interest in California because they may adversely affect water quality and recently have been found in water supplies (California Department of Public Health, 2008b). Perchlorate was analyzed for at all 54 wells in SCI and was detected in approximately 77 percent of the grid wells ( 27 of 35 wells) (5 of 6 LIV grid wells, 13 of 17 GIL grid wells, and 9 of 12 CUY grid wells); however, none of these detections were above the MCL-CA (table 7). In SCI's 19 understanding wells, 1 well (GILU-01) had perchlorate measured just above the MCLCA. NDMA was analyzed for at the 11 slow wells in SCI and was not detected.

\section{Inorganic Constituents}

Unlike the organic constituents and the constituents of special interest, most of the inorganic constituents are naturally present in groundwater, although their concentrations may be influenced by human activities. Inorganic constituents were sampled on both the fast and slow sampling schedule (35 grid and 19 understanding wells) in SCI, while arsenic, chromium, and iron species were sampled only on the slow schedule (7 grid and 4 understanding wells).

Twenty-one of 24 trace elements analyzed in this study have regulatory health-based or nonregulatory aesthetic thresholds. Of the 17 trace elements with health-based thresholds, most detections of the trace elements in SCI grid wells had concentrations below the thresholds (table 8). The exceptions were a few detections of arsenic, molybdenum, and boron above thresholds. In the 12 CUY grid well samples, there were two detections of arsenic above the USEPA maximum contaminant level (MCL-US) of $10 \mu \mathrm{g} / \mathrm{L}$ and three detections of molybdenum above the USEPA lifetime health advisory level (HAL-US) of $40 \mu \mathrm{g} / \mathrm{L}$. Two LIV grid wells samples (of 6) and one GIL grid well sample (of 17) had concentrations of boron above the NL-CA of $1,000 \mu \mathrm{g} / \mathrm{L}$ (table 8).

Results for trace elements for the 19 understanding wells in SCI include detections of five constituents above their respective health-based thresholds. Of the eight LIVU wells sampled, there were two detections of uranium and one detection of arsenic that were above the MCL-US thresholds for these constituents. Additionally, out of the eight LIVU wells, there were two understanding wells that had strontium and one understanding well that had molybdenum measured above their respective HAL-US. Four of the eight LIVU understanding wells and one of the six CUYU understanding wells had boron above the NL-CA. For the understanding wells sampled in the GIL study area, there were no detections of trace elements measured above established health-based thresholds (table 8).

Nutrients (nitrogen and phosphorus) present in groundwater can affect biological activity in aquifers and in surfacewater bodies that receive groundwater discharge. Inorganic nitrogen may be present in the form of ammonia, nitrite, or nitrate, depending on the oxidation-reduction state of the groundwater. High concentrations of nitrate can affect human health adversely, particularly the health of infants. Concentrations of nitrate, nitrite, and ammonia measured in samples from the 54 wells in the SCI study unit were below healthbased thresholds, with the exception of five detections of nitrite plus nitrate, as nitrogen $\left(\mathrm{NO}_{2}^{-}+\mathrm{NO}_{3}^{-}\right)$above the MCLUS of $10 \mathrm{mg} / \mathrm{L}$. These detections occurred in 5 of the $35 \mathrm{SCI}$ grid wells ( 1 of 6 LIV grid wells, 2 of 17 GIL grid wells, and 2 of 12 CUY grid wells) (table 9).

Fluoride is the only major ion with a regulatory healthbased threshold (MCL-CA of $2 \mathrm{mg} / \mathrm{L}$ ); it was detected at a concentration above this threshold in one CUYU understanding well (table 10).

The levels of certain trace elements, major-ion composition, and total dissolved solids (TDS) content in groundwater affect the aesthetic properties of water such as taste, color, and odor, and the technical properties of water such as scaling and staining. Although there are no adverse health effects directly associated with these properties, they may reduce consumer satisfaction with the water or may have economic impacts. CDPH has established nonenforceable thresholds (SMCLCAs) that are based on aesthetic or technical properties rather than on health-based concerns for several trace elements, the ions; chloride and sulfate, and TDS. 
Iron and manganese are trace elements with concentrations affected by the oxidation-reduction state of the groundwater. Precipitation of minerals containing iron or manganese may cause orange, brown, or black staining of surfaces. Iron was detected in 31 of the 54 samples in SCI wells (22 grid and 9 understanding), but only one of these detections (in understanding well LIVU-06) had concentrations above the SMCL-CA (table 8).

Manganese was detected in 45 of the 54 samples in SCI wells (27 grid and 18 understanding). There were eight grid wells (one LIV grid well, five GIL grid wells, and two CUY grid wells) having manganese concentrations above the SMCL-CA of $50 \mu \mathrm{g} / \mathrm{L}$. In the SCI study unit there were four understanding wells (three LIVU understanding wells and one GILU understanding well) where manganese was measured above the SMCL-CA (table 8).

Chloride was detected at concentrations above the upper SMCL-CA threshold of $500 \mathrm{mg} / \mathrm{L}$ in two LIVU understanding wells (table 10).

Sulfate was detected above the recommended SMCL-CA threshold of $250 \mathrm{mg} / \mathrm{L}$ in 17 of the 54 samples in the SCI wells ( 12 of 35 grid wells and 5 of 19 understanding wells). There were nine grid wells (one GIL grid well and eight CUY grid wells) also having measured sulfate concentrations above the upper SMCL-CA threshold of $500 \mathrm{mg} / \mathrm{L}$. Three LIVU understanding wells had measured sulfate concentrations above the upper SMCL-CA (table 10).

TDS was detected above the recommended SMCL-CA threshold of $500 \mathrm{mg} / \mathrm{L}$ in 36 of the 54 samples in the SCI wells ( 25 of 35 grid wells and 11 of 19 understanding wells). There were 10 grid wells ( 3 GIL grid wells and 7 CUY grid wells) having TDS concentrations above upper SMCL-CA threshold of $1,000 \mathrm{mg} / \mathrm{L}$. Four LIVU understanding wells had TDS measured at concentrations above the upper SMCL-CA (table 10).

Arsenic, chromium, and iron occur as different species, depending on the oxidation-reduction state of the groundwater. The oxidized and reduced species have different solubilities in groundwater and may have different effects on human health. The relative proportions of the oxidized and reduced species of each element can be used to aid in interpretation of the oxidation-reduction state of the aquifer. Concentrations of total arsenic, chromium, and iron and the concentration of either the reduced or the oxidized species of each element are reported in table 11. The concentration of the other species can be calculated by difference. The concentrations of arsenic, chromium, and iron reported in table 11 may be different than those reported in table 8 because different analytical methods were used (see Appendix). The concentrations reported in table 8 are considered to be more accurate. Some arsenic, chromium, and iron species analyses were not completed in time for inclusion in this report; complete results will be presented in a subsequent publication.

\section{Isotopic Tracers and Noble Gases}

The isotopic ratios of oxygen and hydrogen in water, the tritium and carbon- 14 activities, and the concentrations of dissolved noble gases may be used as tracers of hydrologic processes. The isotopic ratios of hydrogen and oxygen in water (table 12) aid in the interpretation of the sources of groundwater recharge. These stable isotopic ratios reflect the altitude, latitude, and temperature of precipitation and also the extent of evaporation of the water in surface water bodies or soils prior to infiltration into the aquifer. Concentrations of dissolved noble gases are used to estimate the conditions of groundwater recharge, particularly the temperature of the recharge water. All noble gas analyses and some isotopic ratios of oxygen and hydrogen in water measurements were not completed in time for inclusion in this report; complete results will be presented in a subsequent publication.

Tritium and carbon-14 activities and helium isotope ratios also provide information about the age (time since recharge) of groundwater. Tritium is a short-lived radioactive isotope of hydrogen that is incorporated into the water molecule. Low levels of tritium are produced continuously by interaction of cosmic radiation with the Earth's atmosphere, and a large amount of tritium was produced as a result of atmospheric testing of nuclear weapons between 1952 and 1963. Thus, concentrations of tritium above background generally indicate the presence of water recharged since the early 1950s. Helium isotope ratios are used in conjunction with tritium concentrations to estimate ages for young groundwater. Some tritium activities and all helium isotope ratio analysis were not completed in time for inclusion in this report; complete results will be presented in a subsequent publication.

Carbon-14 (table 12) is a radioactive isotope of carbon. Low levels of carbon-14 are produced continuously by interaction of cosmic radiation with the Earth's atmosphere, and incorporated into atmospheric carbon dioxide. Carbon dioxide dissolves in precipitation, surface water, and groundwater exposed to the atmosphere, thereby entering the hydrologic cycle. Because carbon-14 decays with a half-life of approximately 5,700 years, low activities of carbon-14, relative to modern values, generally indicate a presence of groundwater that is several thousand years old. Some carbon-14 activity analyses were not completed in time for inclusion in this report; complete results will be presented in a subsequent publication.

Of the isotopic tracer constituents analyzed for this study, tritium is the only one with a health-based threshold. Thus far, all measured tritium activities in samples from SCI wells have been about one one-thousandth of the MCL-CA (table 12). 


\section{Radioactive Constituents}

Radioactivity is the release of energy or energetic particles during changes in the structure of the nucleus of an atom. Most of the radioactivity in groundwater comes from decay of naturally occurring isotopes of uranium and thorium that are present in minerals in the sediments or fractured rocks of the aquifer. Both uranium and thorium decay in a series of steps, eventually forming stable isotopes of lead. Radon-222 is a radioactive isotope formed during the uranium or thorium decay series. In each step in the decay series, one radioactive element turns into a different radioactive element by emitting an alpha or a beta particle from its nucleus. The alpha and beta particles emitted during radioactive decay are hazardous to human health because these energetic particles may damage cell DNA and may increase the risk of getting cancer.

Activity often is used instead of concentration for reporting the presence of radioactive constituents. Activity of radioactive constituents in groundwater is measured in units of picocuries per liter ( $\mathrm{pCi} / \mathrm{L})$, and one picocurie is approximately equal to two atoms decaying per minute. The number of atoms decaying is equal to the number of alpha or beta particles emitted. The 11 slow samples in SCI were analyzed for gross alpha and gross beta radioactivity and all samples had activities less than established health-based thresholds (table 13A). Five of the 11 samples collected for gross alpha and gross beta radioactivity activities were either counted after 72 hours or recounted several days after the original count at the laboratory. A delay in the counting by the laboratory may result in lower activities than may have been observed if the count had been preformed within the 72-hour/30-day time period; the results for these five samples are footnoted in table $13 \mathrm{~A}$.

Samples were collected for the analysis of radon-222 from five special studies wells (one grid well and four understanding wells) in the GIL study area. No samples had activities above the proposed alternative MCL-US of 4,000 $\mathrm{pCi} / \mathrm{L}$ (table 13B). The proposed alternative MCL-US will apply if the state or local water agency has an approved multimedia mitigation program to address radon levels in indoor air (U.S. Environmental Protection Agency, 1999).

\section{Future Work}

Subsequent reports will be focused on assessment of the data presented in this report using a variety of statistical, qualitative, and quantitative approaches to evaluate the natural and human factors affecting groundwater quality. Waterquality data contained in the CDPH Databases will be compiled, evaluated, and used in combination with the data that are presented in this report.

\section{Summary}

Groundwater quality in the approximately 653 -squaremile South Coast Interior Basins (SCI) study unit was investigated from August to December 2008, as part of the Priority Basins Project of the Groundwater Ambient Monitoring and Assessment (GAMA) Program. The GAMA Priority Basins Project was developed in response to Legislative mandates (Supplemental Report of the 1999 Budget Act 1999-2000 Fiscal Year; and, the Groundwater-Quality Monitoring Act of 2001 SSections 10780-10782.3 of the California Water Code, Assembly Bill 599\}) to assess and monitor the quality of groundwater used as public supply for municipalities in California, and is being conducted by the U.S. Geological Survey (USGS) in cooperation with the California State Water Resources Control Board (SWRCB). SCI was the 27th study unit to be sampled as part of the GAMA Priority Basins Project.

SCI is located in the South Coast Ranges Hydrologic Province and includes 11 groundwater basins and subbasins defined by the California Department of Water Resources (California Department of Water Resources, 2006; 2004a,b,c,d,e,f,g,h,i,j). The SCI study included assessment of the groundwater quality from 54 wells in Alameda, Santa Clara, San Benito, Santa Barbara, Ventura, and Kern Counties, California. Thirty-five of the wells were selected using a randomized grid approach to achieve statistically unbiased representation of groundwater used for public drinking-water supplies. Nineteen of the wells were selected to provide additional sampling density to aid in understanding processes affecting groundwater quality.

Groundwater samples were analyzed for volatile organic compounds (VOCs), pesticides and pesticide degradates, polar pesticide and metabolites, pharmaceutical compounds, perchlorate, NDMA, trace elements, nutrients, major and minor ions, silica, total dissolved solids (TDS), alkalinity, and radioactivity (gross alpha and gross beta radiation and radon-222). Naturally occurring isotopes [stable isotopes of hydrogen, oxygen, and carbon, and activities of tritium and carbon-14] and dissolved noble gases also were measured to provide a data set that will be used to help interpret the sources and ages of the sampled groundwater. In total, 288 constituents and water-quality indicators (field parameters) were investigated for this study. This report describes the sampling, analytical, and quality-assurance methods used in the study, and presents the results of the chemical analyses made of the groundwater samples. 
This study did not attempt to evaluate the quality of water delivered to consumers; after withdrawal from the ground, water typically is treated, disinfected, and blended with other waters to maintain acceptable water quality. Regulatory thresholds apply to treated water that is served to the consumer, not to untreated groundwater. However, to provide some context for the results, concentrations of constituents measured in the untreated groundwater were compared with regulatory and nonregulatory health-based thresholds established by the U.S. Environmental Protection Agency (USEPA) and California Department of Public Health (CDPH) and nonregulatory thresholds established for aesthetic and technical concerns by CDPH.

All detections of VOCs and pesticides in samples from the 54 SCI grid and understanding wells were below healthbased thresholds; additionally, all of the detections of organic and special interest constituents from SCI grid and understanding wells were below health-based thresholds, with the exception of a single understanding well detection of perchlorate above the CDPH maximum contaminant level (MCL-CA).

Results from SCI grid wells showed that most detections of trace elements and nutrients in samples from the 35 grid wells were below health-based thresholds. Exceptions include: two detections of arsenic and five detections of nitrite plus nitrate, as nitrogen $\left(\mathrm{NO}_{2}^{-}+\mathrm{NO}_{3}^{-}\right)$above the USEPA maximum contaminant level (MCL-US), three detections of boron and three detections of molybdenum that were above the USEPA lifetime health advisory level (HAL-US). All detections of gross alpha and gross beta radioactivity in SCI grid wells were below health-based thresholds.

Most of the samples from SCI grid wells collected for trace elements, major ions, and TDS had concentrations measured below the nonenforceable thresholds set for aesthetic concerns. Eight grid wells (of 35 sampled) in SCI had detections of manganese above the SMCL-CA of $50 \mu \mathrm{g} / \mathrm{L}$. Twelve grid wells had sulfate measured at a concentration above the recommended SMCL-CA threshold of $250 \mathrm{mg} / \mathrm{L}$ and nine of these also were above the upper SMCL-CA threshold of $500 \mathrm{mg} / \mathrm{L}$. Twenty-five grid wells (of 35 sampled) had TDS concentrations above the SMCL-CA recommended threshold and 10 of these wells also were above the SMCL-CA upper threshold (SMCL-CA threshold for TDS has a recommended value of $500 \mathrm{mg} / \mathrm{L}$ and an upper value of $1,000 \mathrm{mg} / \mathrm{L}$ ).

Results from the 19 understanding wells in SCI showed one detection of arsenic and two detections of uranium that were above the USEPA maximum contaminant levels (MCLUS). Two understanding wells had strontium and one understanding well had molybdenum, measured above the USEPA lifetime health advisory levels (HAL-US). One understanding well had a fluoride concentration above the MCL-CA, and five wells had concentrations of boron above the NL-CA. One understanding well had iron measured at a concentration above the SMCL-CA of $300 \mu \mathrm{g} / \mathrm{L}$. One understanding well had sulfate measured above the recommended SMCLCA threshold of $250 \mathrm{mg} / \mathrm{L}$ and two understanding wells had chloride levels above the upper SMCL-CA threshold of
$500 \mathrm{mg} / \mathrm{L}$. Twelve understanding wells (of 19 sampled) had TDS concentrations above the SMCL-CA recommended lower threshold and four of these wells also had concentrations above the upper threshold. Samples were collected for the analysis of radon-222 from five special studies wells (one grid well and four understanding wells) in the GIL study area, and all had activities of radon-222 below the proposed alternative MCL-US of 4,000 pCi/L.

\section{Acknowledgments}

The authors thank the following cooperators for their support: the State Water Resources Control Board, California Department of Public Health, California Department of Water Resources, and Lawrence Livermore National Laboratory. We especially thank the well owners and water purveyors for their generosity in allowing the USGS to collect samples from their wells.

\section{References Cited}

American Public Health Association, 1998, Standard methods for the examination of water and wastewater (20th ed.): Washington, D.C., American Public Health Association, American Water Works Association, and Water Environment Federation, p. 3-37-3-43.

American Society for Testing and Materials, 1998, Annual book of ASTM standards - water and environmental technology: Philadelphia, Pennsylvania, American Society for Testing and Materials, v. 11.02 (Water II), p. 664-666.

Anderson, R.L., 1987, Practical statistics for analytical chemists: New York, Van Nostrand Reinhold Company, Inc., $315 \mathrm{p}$.

Ball, J.W., and McCleskey, R.B., 2003a, A new cationexchange method for accurate field speciation of hexavalent chromium: U.S. Geological Survey Water-Resources Investigations Report 03-4018, 17 p.

Ball, J.W., and McCleskey, R.B., 2003b, A new cationexchange method for accurate field speciation of hexavalent chromium: Talanta, v. 61, p. 305-313.

Belitz, Kenneth, Dubrovsky, N.M., Burow, K.R., Jurgens, Bryant, and Johnson, Tyler, 2003, Framework for a groundwater quality monitoring and assessment program for California: U.S. Geological Survey Water-Resources Investigations Report 03-4166, 78 p. 
Bennett, G.L., V, Belitz, Kenneth, and Milby Dawson, B.J., 2006, California GAMA Program - Groundwater quality data in the northern San Joaquin basin study unit, 2005: U.S. Geological Survey Data Series 196, 122 p.

Burton, C.A., and Belitz, Kenneth, 2008, Groundwater quality data in the southeast San Joaquin Valley, 2005-2006Results from the California GAMA Program: U.S. Geological Survey Data Series 351, 103 p.

California Department of Public Health, 2008a, California drinking water-related laws: Drinking water-related regulations (Title 22), accessed December 17, 2008, at http://www. cdph.ca.gov/certlic/drinkingwater/Pages/Lawbook.aspx

California Department of Public Health, 2008b, Drinking water notification levels: Notification levels, accessed December 17, 2008, at http://www.cdph.ca.gov/certlic/ drinkingwater/Pages/NotificationLevels.aspx

California Department of Water Resources, 2003, California's groundwater: California Department of Water Resources Bulletin 118, 246 p., accessed January 6, 2009, at http:// www.groundwater.water.ca.gov/bulletin 118

California Department of Water Resources, 2004a, California's groundwater: Individual basin descriptions, GilroyHollister Valley; Llagas Subbasin: California Department of Water Resources Bulletin 118, accessed January 6, 2009, at http://www.dpla2.water.ca.gov/publications/groundwater/ bulletin118/basins/pdfs_desc/3-3.01.pdf

California Department of Water Resources, 2004b, California's groundwater: Individual basin descriptions, GilroyHollister Valley; Bolsa Area Subbasin: California Department of Water Resources Bulletin 118, accessed January 6, 2009, at http://www.dpla2.water.ca.gov/publications/ groundwater/bulletin118/basins/pdfs_desc/3-3.02.pdf

California Department of Water Resources, 2004c, California's groundwater: Individual basin descriptions, Gilroy-Hollister Valley; Hollister Area Subbasin: California Department of Water Resources Bulletin 118, accessed January 6, 2009, at http://www.dpla2.water.ca.gov/publications/groundwater/ bulletin118/basins/pdfs_desc/3-3.03.pdf

California Department of Water Resources, 2004d, California's groundwater: Individual basin descriptions, Gilroy-Hollister Valley; San Juan Bautista Area Subbasin: California Department of Water Resources Bulletin 118, accessed January 6, 2009, at http://www.dpla2.water.ca.gov/ publications/groundwater/bulletin118/basins/pdfs_desc/33.04.pdf
California Department of Water Resources, 2004e, California's groundwater: Individual basin descriptions, Cuyama Valley: California Department of Water Resources Bulletin 118, accessed January 6, 2009, at http://www.dpla2. water.ca.gov/publications/groundwater/bulletin118/basins/ pdfs_desc/3-3.13.pdf

California Department of Water Resources, 2004f, California's groundwater: Individual basin descriptions, Castaic Lake Valley: California Department of Water Resources Bulletin 118, accessed January 6, 2009, at http://www.dpla2. water.ca.gov/publications/groundwater/bulletin118/basins/ pdfs_desc/5-29.pdf

California Department of Water Resources, 2004g, California's groundwater: Individual basin descriptions, Cuddy Canyon Valley: California Department of Water Resources Bulletin 118, accessed January 6, 2009, at http://www.dpla2. water.ca.gov/publications/groundwater/bulletin118/basins/ pdfs_desc/5-82.pdf

California Department of Water Resources, 2004h, California's groundwater: Individual basin descriptions, Cuddy Ranch Area: California Department of Water Resources Bulletin 118, accessed January 6, 2009, at http://www.dpla2. water.ca.gov/publications/groundwater/bulletin118/basins/ pdfs_desc/5-83.pdf

California Department of Water Resources, 2004i, California's groundwater: Individual basin descriptions, Cuddy Valley: California Department of Water Resources Bulletin 118, accessed January 6, 2009, at http://www.dpla2.water.ca.gov/ publications/groundwater/bulletin118/basins/pdfs_desc/584.pdf

California Department of Water Resources, 2004j, California's groundwater: Individual basin descriptions, Mil Potrero: California Department of Water Resources Bulletin 118, accessed January 6, 2009, at http://www.dpla2.water.ca.gov/ publications/groundwater/bulletin118/basins/pdfs_desc/585.pdf

California Department of Water Resources, 2006, California's groundwater: Individual basin descriptions, Livermore Valley: California Department of Water Resources Bulletin 118, accessed January 6, 2009, at http://www.dpla2. water.ca.gov/publications/groundwater/bulletin118/basins/ pdfs_desc/2-10.pdf

Childress, C.J.O., Foreman, W.T., Connor, B.F., and Maloney, T.J., 1999, New reporting procedures based on longterm method-detection levels and some considerations for interpretations of water-quality data provided by the U.S. Geological Survey National Water-Quality Laboratory: U.S. Geological Survey Open-File Report 99-193, 19 p. 
Connor, B.F., Rose, D.L., Noriega, M.C., Murtagh, L.K., and Abney, S.R., 1998, Methods of analysis by the U.S. Geological Survey National Water Quality Laboratory-Determination of 86 volatile organic compounds in water by gas chromatography/mass spectrometry, including detections less than reporting limits: U.S. Geological Survey OpenFile Report 97-829, 78 p.

Coplen, T.B., Wildman, J.D., and Chen, J., 1991, Improvements in the gaseous hydrogen-water equilibrium technique for hydrogen isotope analysis: Analytical Chemistry, v. 63, p. 910-912.

Coplen, T.B., 1994, Reporting of stable hydrogen, carbon, and oxygen isotopic abundances: Pure and Applied Chemistry, v. 66, p. $273-276$.

Coplen, T.B., Hopple, J.A., Bohlke, J.K., Peiser, H.S., Rieder, S.E., Krouse, H.R., Rosman, K.J.R., Ding, T., Vocke, R.D., Jr., Revesz, K.M., Lamberty, A., Taylor, P., and DeBierve, P., 2002, Compilation of minimum and maximum isotope ratios of selected elements in naturally occurring terrestrial materials and reagents: U.S. Geological Survey WaterResources Investigations Report 01-4222, 98 p.

Dawson, B.J., Bennett, G.L., V, and Belitz, Kenneth, 2008, California GAMA Program: Groundwater quality data in the Southern Sacramento Valley study unit, California, 2005: U.S. Geological Survey Data Series 285, 93 p.

Eaton, G.F., Hudson, G.B., and Moran, J.E., 2004, Tritiumhelium-3 age-dating of groundwater in the Livermore Valley of California: American Chemical Society ACS Symposium Series, v. 868 , p. 235-245.

Epstein, S., and Mayeda, T.K., 1953, Variation of O-18 content of water from natural sources: Geochimica et Cosmochimica Acta, v. 4, p. 213-224.

Faires, L.M., 1993, Methods of analysis by the U.S. Geological Survey National Water Quality Laboratory-Determination of metals in water by inductively coupled plasma-mass spectrometry: U.S. Geological Survey Open-File Report 92-634, $28 \mathrm{p}$.

Ferrari, M.J., Fram, M.S., and Belitz, Kenneth, 2008, Groundwater quality in the central Sierra study unit, California, 2006: Results from the California GAMA program: U.S. Geological Survey Data Series 335, 60 p.

Firestone, R.B., Shirley, V.S., Baglin, C.M., Chu, S.Y.F., and Zipkin, J., 1996, Table of Isotopes ( $8^{\text {th }}$ ed.): New York, John Wiley \& Sons, 3,168 p., accessed December 16, 2008, at http://ie.lbl.gov/toipdf/toi20.pdf

Fishman, M.J., and Friedman, L.C., 1989, Methods for determination of inorganic substances in water and fluvial sediments: U.S. Geological Survey Techniques of WaterResources Investigations, book 5, chap. A1, 545 p.
Fishman, M.J., 1993, Methods of analysis by the U.S. Geological Survey National Water Quality Laboratory-Determination of inorganic and organic constituents in water and fluvial sediments: U.S. Geological Survey Open-File Report 93-125, $217 \mathrm{p}$.

Fram, M.S., and Belitz, Kenneth, 2007, Groundwater quality data in the Southern Sierra Study Unit, 2006: Results from the California GAMA Program: U.S. Geological Survey Data Series 258, 78 p.

Fram, M.S., Munday, Cathy, and Belitz, Kenneth, 2009, Groundwater quality data for the Tahoe-Martis study unit, 2007: Results from the California GAMA Program: U.S. Geological survey Data-Series 432, 88 p.

Furlong, E.T., Anderson, B.D., Werner, S.L., Soliven, P.P., Coffey, L.J., and Burkhardt, M.R., 2001, Methods of analysis by the U.S. Geological Survey National Water Quality Laboratory-Determination of pesticides in water by graphitized carbon-based solid-phase extraction and high-performance liquid chromatography/mass spectrometry: U.S. Geological Survey Water-Resources Investigations Report 01-4134, $73 \mathrm{p}$.

Furlong, E.T., Werner, S.L., Anderson, B.D., and Cahill, J.D., 2008, Methods of analysis by the U.S. Geological Survey National Water Quality Laboratory-Determination of human-health pharmaceuticals in filtered water by chemically modified styrene-divinylbenzene resin-based solidphase extraction and high-performance liquid chromatography/mass spectrometry: U.S. Geological Survey Techniques and Methods, book 5, chap. B5, 56 p.

Garbarino, J.R., 1999, Methods of analysis by the U.S. Geological Survey National Water Quality Laboratory-Determination of dissolved arsenic, boron, lithium, selenium, strontium, thalium, and vanadium using inductively coupled plasma-mass spectrometry: U.S. Geological Survey OpenFile Report 99-093, 31 p.

Garbarino, J.R., and Damrau, D.L., 2001, Methods of analysis by the U.S. Geological Survey National Water Quality Laboratory-Determination of organic plus inorganic mercury in filtered and unfiltered natural water with cold vaporatomic fluorescence spectrometry: U.S. Geological Survey Water-Resources Investigations Report 01-4132, 16 p.

Garbarino, J.R., Kanagy, J.R., and Cree, M.E., 2006, Determination of elements in natural-water, biota, sediment, and soil samples using collision/reaction cell inductively coupled plasma-mass spectrometry: U.S. Geological Survey Techniques and Methods, book 5, chap. B1, 88 p. 
Gilliom, R.J., Barbash, J.E., Crawford, C.G., Hamilton, P.A., Martin, J.D., Nakagaki, N., Nowell, L.H., Scott, J.C., Stackelberg, P.E., Thelin, G.P., and Wolock, D.M., 2006, The quality of our nation's waters: Pesticides in the nation's streams and groundwater, 1992-2001: U.S. Geological Survey Circular 1291, 172 p.

Gran, G., 1952, Determination of the equivalence point in potentiometric titration, Part II: Analyst, v. 77, p. 661-671.

Grob, R.L, ed., 1995, Modern practice of gas chromatography (3rd ed.): New York, John Wiley \& Sons, 888 p.

Hahn, G.J., and Meeker W.Q., 1991, Statistical intervals: a guide for practitioners: New York, John Wiley \& Sons, $392 \mathrm{p}$.

Hutson, S.S., Barber, N.L., Kenny, J.F., Linsey, K.S., Lumia, D.S., and Maupin, M.A., 2004, Estimated use of water in the United States in 2000: U.S. Geological Survey Circular 1268,46 p.

Karlen, I., Olsson, I.U., Kallburg, P., and Kilici, S., 1964, Absolute determination of the activity of two ${ }^{14} \mathrm{C}$ dating standards: ArkivGeofysik, v. 4, p. 465-471.

Kent, Robert, and Belitz, Kenneth, 2009, Ground-water quality data in the Upper Santa Ana Watershed Study Unit, November 2006 to March 2007: Results from the California GAMA Program: U.S. Geological Survey Data-Series 404, $116 \mathrm{p}$.

Kolpin, D.W., Furlong, E.T., Meyer, M.T., Thurman, E.M., Zaugg, S.D., Barber, L.B., and Buxton, H.T., 2002, Pharmaceuticals, hormones and other organic wastewater contaminants in U.S. streams, 1999-2000: Environmental Science \& Technology, v. 36, no. 6, p. 1202-1211.

Koterba, M.T., Wilde, F.D., and Lapham, W.W., 1995, Groundwater data-collection protocols and procedures for the National Water-Quality Assessment Program-Collection and documentation of water-quality samples and related data: U.S. Geological Survey Open-File Report 95-399, $113 \mathrm{p}$.

Kreiger, H.L., and Whittaker, E.L., 1980, Prescribed procedures for measurement of radioactivity in drinking water: U.S. Environmental Protection Agency EPA-600-4-80-032, 142 p., available from the National Technical Information Service as PB80-224744 at http://www.ntis.gov

Kulongoski, J.T., and Belitz, Kenneth, 2004, Groundwater ambient monitoring and assessment program: U.S. Geological Survey Fact Sheet 2004-3088, 2 p.
Kulongoski, J.T., Belitz, Kenneth, and Dawson, B.J., 2006, Groundwater quality data in the North San Francisco Bay Hydrogeologic provinces, California, 2004: Results from the California Groundwater Ambient Monitoring and Assessment (GAMA) Program: U.S. Geological Survey Data Series 167, 100 p.

Kulongoski, J.T., and Belitz, Kenneth, 2007, Groundwater quality data in the Monterey Bay and Salinas Valley Basins, California, 2005-Results from the California GAMA Program: U.S. Geological Survey Data Series 258, 84 p.

Land, M.K., and Belitz, Kenneth, 2008, Groundwater quality data in the San Fernando-San Gabriel study unit, 2005Results from the California GAMA Program: U.S. Geological Survey Data Series 356, 84 p.

Landon, M.K., and Belitz, Kenneth, 2008, Groundwater quality data in the Central Eastside San Joaquin Basin 2006Results from the California GAMA Program: U.S. Geological Survey Data Series 325, 88 p.

Lane, S.L., Flanagan, Sarah, and Wilde, F.D., 2003, Selection of equipment for water sampling (ver. 2.0): U.S. Geological Survey Techniques of Water-Resources Investigations, book 9, chap. A2, accessed December 17, 2008, at http:// pubs.water.usgs.gov/twri9A2/

Lewis, M.E., 2006, Dissolved oxygen (ver. 2.1): U.S. Geological Survey Techniques of Water-Resources Investigations, book 9, chap. A6.2, accessed December 16, 2008, at http:// pubs.water.usgs.gov/twri9A6.2/

Lindley, C.E., Stewart, J.T., and Sandstrom, M.W., 1996, Determination of low concentrations of acetochlor in water by automated solid-phase extraction and gas chromatography with mass selective detection: Journal of AOAC International, v. 79, no. 4, p. 962-966.

Madsen, J.E., Sandstrom, M.W., and Zaugg, S.D., 2003, Methods of analysis by the U.S. Geological Survey National Water Quality Laboratory-A method supplement for the determination of fipronil and degradates in water by gas chromatography/mass spectrometry: U.S. Geological Survey Open-File Report 02-462, 11 p.

Maloney, T.J., ed., 2005, Quality management system, U.S. Geological Survey National Water Quality Laboratory: U.S. Geological Survey Open-File Report 2005-1263, accessed December 16, 2008, at http://pubs.usgs.gov/of/2005/1263/ pdf/OFR2005-1263.pdf

Mathany, T.M., Land, Michael, and Belitz, Kenneth, 2008, Groundwater quality data in the Coastal Los Angeles Basin Study Unit, 2006 - Results from the California GAMA Program: U.S. Geological Survey Data Series 387, 98 p. 
Mathany, T.M. and Belitz, Kenneth, 2009, Ground-Water Quality Data in the Mojave Study Unit, 2008: Results from the California GAMA Program: U.S. Geological Survey Data-Series 440, $80 \mathrm{p}$.

McCleskey, R.B., Nordstrom, D.K., and Ball, J.W., 2003, Metal interferences and their removal prior to the determination of $\mathrm{As}(\mathrm{T})$ and $\mathrm{As}(\mathrm{III})$ in acid mine waters by hydride generation atomic absorption spectrometry: U.S. Geological Survey Water-Resources Investigations Report 03-4117, $14 \mathrm{p}$.

McCurdy, D.E., Garbarino, J.R., and Mullin, A.H., 2008, Interpreting and reporting radiological water-quality data: U.S. Geological Survey Techniques and Methods, book 5, chap. B6, 33 p.

McLain, Betty, 1993, Methods of analysis by the U.S. Geological Survey National Water Quality Laboratory-Determination of chromium in water by graphite furnace atomic absorption spectrophotometry: U.S. Geological Survey Open-File Report 93-449, 16 p.

Montrella, Joseph, and Belitz, Kenneth, 2009, Groundwater quality data in the Santa Clara River Valley study unit, 2007-Results from the California GAMA Program: U.S. Geological Survey Data Series 408, 84 p.

Moran, J.E., Hudson, G.B., Eaton, G.F., and Leif, R., 2002, A contamination vulnerability assessment for the LivermoreAmador and Niles Cone Groundwater Basins: Berkeley, Calif., Lawrence Livermore National Laboratory report UCRL-AR-148831, 25 p.

Mueller, D.K., and Titus, C.J., 2005, Quality of nutrient data from streams and groundwater sampled during water years 1992-2001: U.S. Geological Survey Scientific Investigations Report 2005-5106, 27 p.

Olsson, I.U., 1970, The use of Oxalic acid as a Standard, in Olsson, I.U., ed., Radiocarbon Variations and Absolute Chronology, Nobel Symposium, 12th Proc.: New York, John Wiley \& Sons, p. 17.

Patton, C.J., and Kryskalla, J.R., 2003, Methods of analysis by the U.S. Geological Survey National Water Quality Laboratory-Evaluation of alkaline persulfate digestion as an alternative to Kjeldahl digestion for determination of total and dissolved nitrogen and phosphorous in water: U.S. Geological Survey Water-Resources Investigations Report 03-4174, 33 p.

Pirkey, K.D., and Glodt, S.R., 1998, Quality control at the U.S. Geological Survey National Water Quality Laboratory: U.S. Geological Survey Fact-Sheet 026-98, 4 p., accessed June 4, 2009, at http://pubs.er.usgs.gov/usgspubs/fs/fs02698
Plomley, J.B., Koester, C.J., and March, R.E., 1994, Determination of NDMA in complex environmental matrices by quadrupole ion storage tandem mass spectrometry enhanced by unidirectional ion ejection: Analytical Chemistry, v. 66, no. 24 , p. 4437-4443.

Radtke, D.B., Davis, J.V., and Wilde, F.D., 2005, Specific electrical conductance (ver. 1.2): U.S. Geological Survey Techniques of Water-Resources Investigations, book 9, chap. A6.3, accessed December 16, 2008, at http://pubs. water.usgs.gov/twri9A6.3/

Ray, M.C., Kulongoski, J.T., and Belitz, Kenneth, 2009, Groundwater quality data in the San Francisco Bay study unit, 2007-Results from the California GAMA program: U.S. Geological Survey Data Series 396, 92 p.

Sandstrom, M.W., Stroppel, M.E., Foreman, W.T., and Schroeder, M.P., 2001, Methods of analysis by the U.S. Geological Survey National Water Quality Laboratory-Determination of moderate-use pesticides and selected degradates in water by $\mathrm{C}-18$ solid-phase extraction and gas chromatography/mass spectrometry: U.S. Geological Survey WaterResources Investigations Report 01-4098, 70 p.

Schmitt, S.J., Fram, M.S., Milby Dawson, B.J., Belitz, Kenneth, 2008, Groundwater quality data in the middle Sacramento Valley study unit, 2006 - results from the California GAMA program: U.S. Geological Survey Data Series 385, $100 \mathrm{p}$.

Scott, J.C., 1990, Computerized stratified random site selection approaches for design of a groundwater quality sampling network: U.S. Geological Survey Water-Resources Investigations Report 90-4101, 109 p.

Shelton, J.L., Burow, K.R., Belitz, Kenneth, Dubrovsky, N.M., Land, M.T., and Gronberg, J.M., 2001, Low-level volatile organic compounds in active public supply wells as groundwater tracers in the Los Angeles physiographic basin, California, 2000: U.S. Geological Survey Water-Resources Investigations Report 01-4188, 29 p.

Shelton, J.L., Pimentel, Isabel, Fram, M.S., Belitz, Kenneth, 2008, Groundwater quality in the Kern County Subbasin Study Unit, 2006 - Results from the California GAMA Program: U.S. Geological Survey Data Series 337, 75 p.

State Water Resources Control Board, 2003, Report to the Governor and Legislature, A comprehensive groundwater quality monitoring program for California: Assembly Bill 599 March 2003, 100 p., accessed June 4, 2009, at http:// www.waterboards.ca.gov/gama/docs/final_ab_599_rpt_to_ legis_7_31_03.pdf

Stookey, L.L., 1970, FerroZine-A new spectrophotometric reagent for iron: Analytical Chemistry, v. 42, p. 779-781. 
Stuiver, M., 1980, Workshop on ${ }^{14} \mathrm{C}$ data reporting: Radiocarbon, v. 22, p. 964-966.

Stuiver, M., and Polach, H.A., 1977, Discussion-Reporting of ${ }^{14} \mathrm{C}$ data: Radiocarbon, v. 19 , p. $355-363$.

Thatcher, L.L., Janzer, V.J., and Edwards, K.W., 1977, Methods for the determination of radioactive substances in water: U.S. Geological Survey Techniques of Water-Resources Investigations, book 5, chap. A5, 95 p.

Timme, P.J., 1995, National Water Quality Laboratory 1995 services catalog: U.S. Geological Survey Open-File Report 95-352, $120 \mathrm{p}$.

To, T.B., Nordstrom, D.K., Cunningham, K.M., Ball, J.W., and McCleskey, R.B., 1998, New method for the direct determination of dissolved $\mathrm{Fe}$ (III) concentration in acid mine waters: Environmental Science and Technology, v. 33, p. 807-813.

U.S. Environmental Protection Agency, 1989, Semivolatile organic compounds by isotope dilution GSMS (July 1989): Washington, D.C., U.S. Environmental Protection Agency, $68 \mathrm{p}$.

U.S. Environmental Protection Agency, 1999, National primary drinking water regulations, Radon-222: Federal Register, v. 64, no. 211, p. 59245-59294.

U.S. Environmental Protection Agency, 2002, Guidelines for establishing procedures for the analysis of pollutants: U.S. Code of Federal Regulations, Title 40, 136 p.

U.S. Environmental Protection Agency, 2005, Method 331.0 Determination of perchlorate in drinking water by liquid chromatography electrospray ionization mass spectrometry (Revision 1.0, January 2005): Office of Ground Water and Drinking Water, EPA Document \#815-R-05-007, 34 p., accessed December 16, 2008, at http://www.epa.gov/ safewater/methods/pdfs/methods/met331_0.pdf

U.S. Environmental Protection Agency, 2008a, Drinking water contaminants, accessed January 2, 2009, at http://www.epa. gov/safewater/contaminants/index.html

U.S. Environmental Protection Agency, 2008b, Drinking water health advisories - 2006 Drinking water standards and health advisory tables, accessed January 2, 2009, at http:// www.epa.gov/waterscience/criteria/drinking/

U.S. Environmental Protection Agency, 2008c, Proposed radon in drinking water rule, accessed January 2, 2009, at http://www.epa.gov/safewater/radon/proposal.html

U.S. Geological Survey Branch of Quality Systems, 2008, Inorganic blind sample project, accessed January 8, 2009, at http://bqs.usgs.gov/bsp/.
U.S. Geological Survey, variously dated, National field manual for the collection of water-quality data: U.S. Geological Survey Techniques of Water-Resources Investigations, book 9, chap. A1-A9, accessed January 7, 2009, at http:// water.usgs.gov/owq/FieldManual/

Weiss, R.F., 1968, Piggyback sampler for dissolved gas studies on sealed water samples: Deep Sea Research, v. 15, p. 721-735.

Wilde, F.D., 2006, Temperature (ver. 2): U.S. Geological Survey Techniques of Water-Resources Investigations, book 9, chap. A6.1, accessed January 7, 2009, at http://pubs.water. usgs.gov/twri9A6.1/

Wilde, F.D., ed., 2004, Cleaning of equipment for water sampling (ver. 2.0): U.S. Geological Survey Techniques of Water-Resources Investigations, book 9, chap. A3, accessed January 7, 2009, at http://pubs.water.usgs.gov/twri9A3/

Wilde, F.D., Busenberg, E., and Radtke, D.B., 2006, pH (ver. 1.3): U.S. Geological Survey Techniques of WaterResources Investigations, book 9, chap. A6.4, accessed January 7, 2009, at http://pubs.water.usgs.gov/twri9A6.4/

Wilde, F.D., and Radtke, D.B., 2005, General information and guidelines (ver. 1.2): U.S. Geological Survey Techniques of Water-Resources Investigations, book 9, chap. A6.0, accessed January 7, 2009, at http://pubs.water.usgs.gov/ twri9A6.0/

Wilde, F.D., Radtke, D.B., Gibs, J., and Iwatsubo, R.T., 1999, Collection of water samples: U.S. Geological Survey Techniques of Water-Resources Investigations, book 9, chap. A4, accessed January 7, 2009, at http://pubs.water.usgs.gov/ twri9A4/

Wilde, F.D., Radtke, D.B., Gibs, J., and Iwatsubo, R.T., 2004, Processing of water samples: U.S. Geological Survey Techniques of Water-Resources Investigations, book 9, chap. A5, accessed January 7, 2009, at http://pubs.water.usgs.gov/ twri9A5/

Wright, M.T., Belitz, Kenneth, and Burton, C.A., 2005, California GAMA Program - Groundwater quality in the San Diego drainages hydrologic province, California, 2004: U.S. Geological Survey Data Series 129, 91 p.

Zaugg, S.D., Sandstrom, M.W., Smith, S.G., and Fehlberg, K.M., 1995, Methods of analysis by the U.S. Geological Survey National Water Quality Laboratory-Determination of pesticides in water by $\mathrm{C}-18$ solid-phase extraction and capillary-column gas chromatography/mass spectrometry: U.S. Geological Survey Open-File Report 95-181, 60 p. 


\section{Tables}


Table 1. Identification, sampling, and construction information for wells sampled for the South Coast Interior Basins Groundwater Ambient Monitoring and Assessment (GAMA) study, California, August to December 2008.

[Sampling schedule: described in table 2. Elevation of LSD: a datum plane that is approximately at land surface at each well. The elevation of the LSD is described in feet above the North American Vertical Datum 1988 (NAVD 88). GAMA well identification number.: LIV, Livermore study area grid well; LIVU, Livermore study area understanding well; GIL, Gilroy study area grid well; GILU, Gilroy study area understanding well; CUY, Cuyama study area grid well; CUYU, Cuyama study area understanding well. Abbreviations: ft, foot; LSD, land surface datum; na, not available]

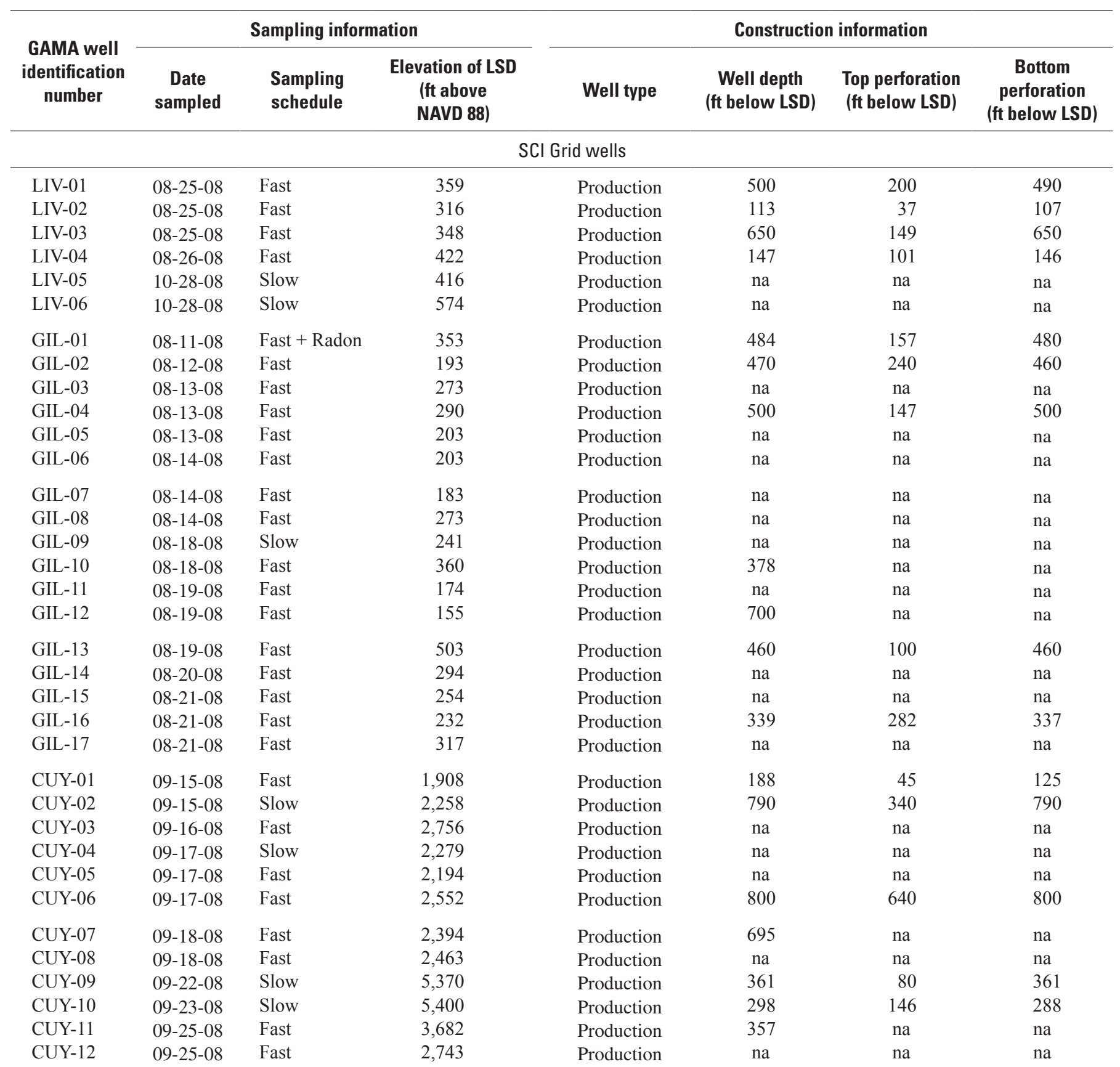


Table 1. Identification, sampling, and construction information for wells sampled for the South Coast Interior Basins Groundwater Ambient Monitoring and Assessment (GAMA) study, California, August to December 2008. - Continued

[Sampling schedule: described in table 2. Elevation of LSD: a datum plane that is approximately at land surface at each well. The elevation of the LSD is described in feet above the North American Vertical Datum 1988 (NAVD 88). GAMA well identification number: LIV, Livermore study area grid well; LIVU, Livermore study area understanding well; GIL, Gilroy study area grid well; GILU, Gilroy study area understanding well; CUY, Cuyama study area grid well; CUYU, Cuyama study area understanding well. Abbreviations: ft, foot; LSD, land surface datum; na, not available]

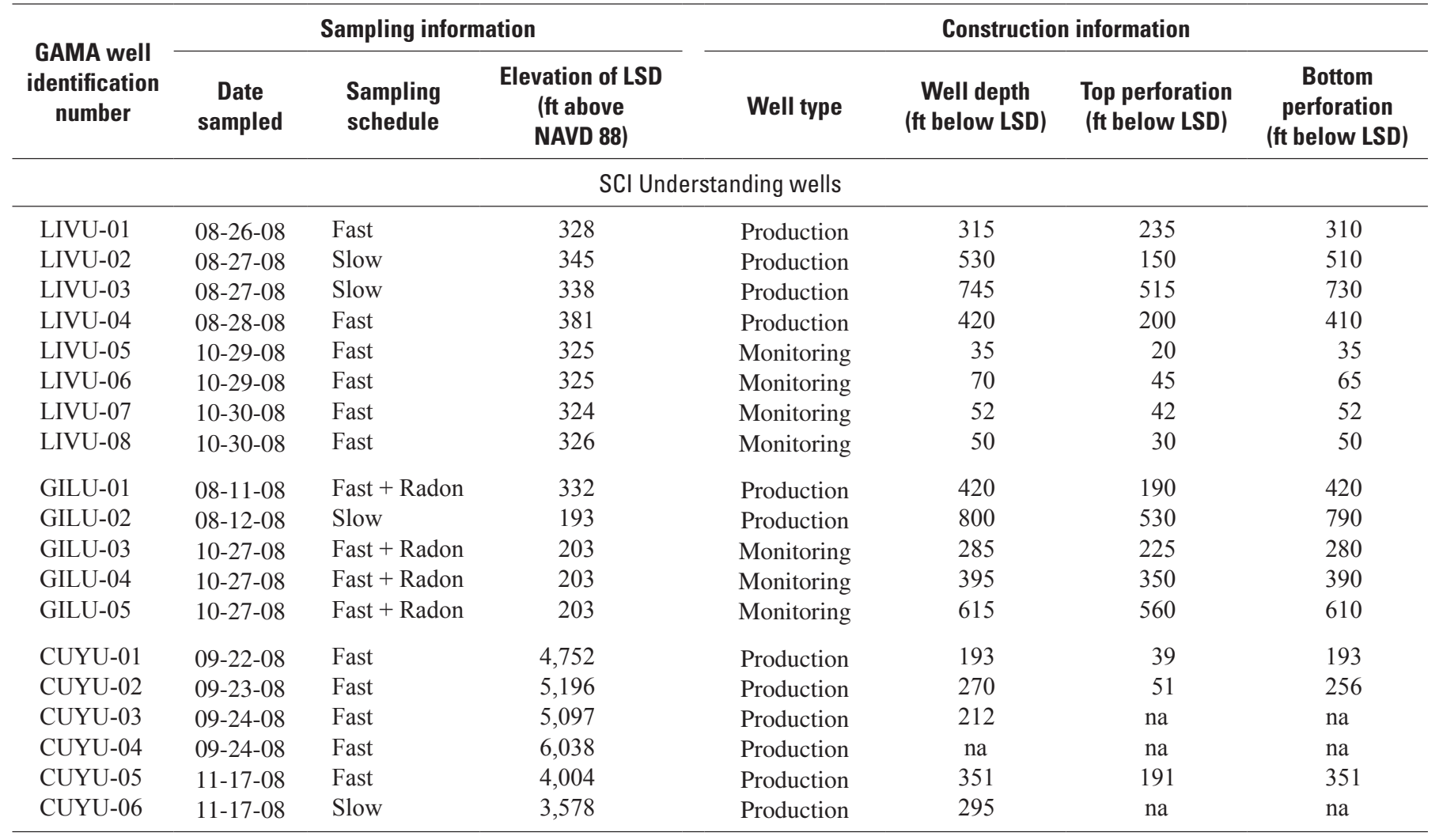


Table 2. Classes of chemical consistuents and water-quality indicators (field parameters) collected for the slow and fast well sampling schedules in the South Coast Interior Basins Groundwater Ambient Monitoring and Assessment (GAMA) study, California, August to December 2008.

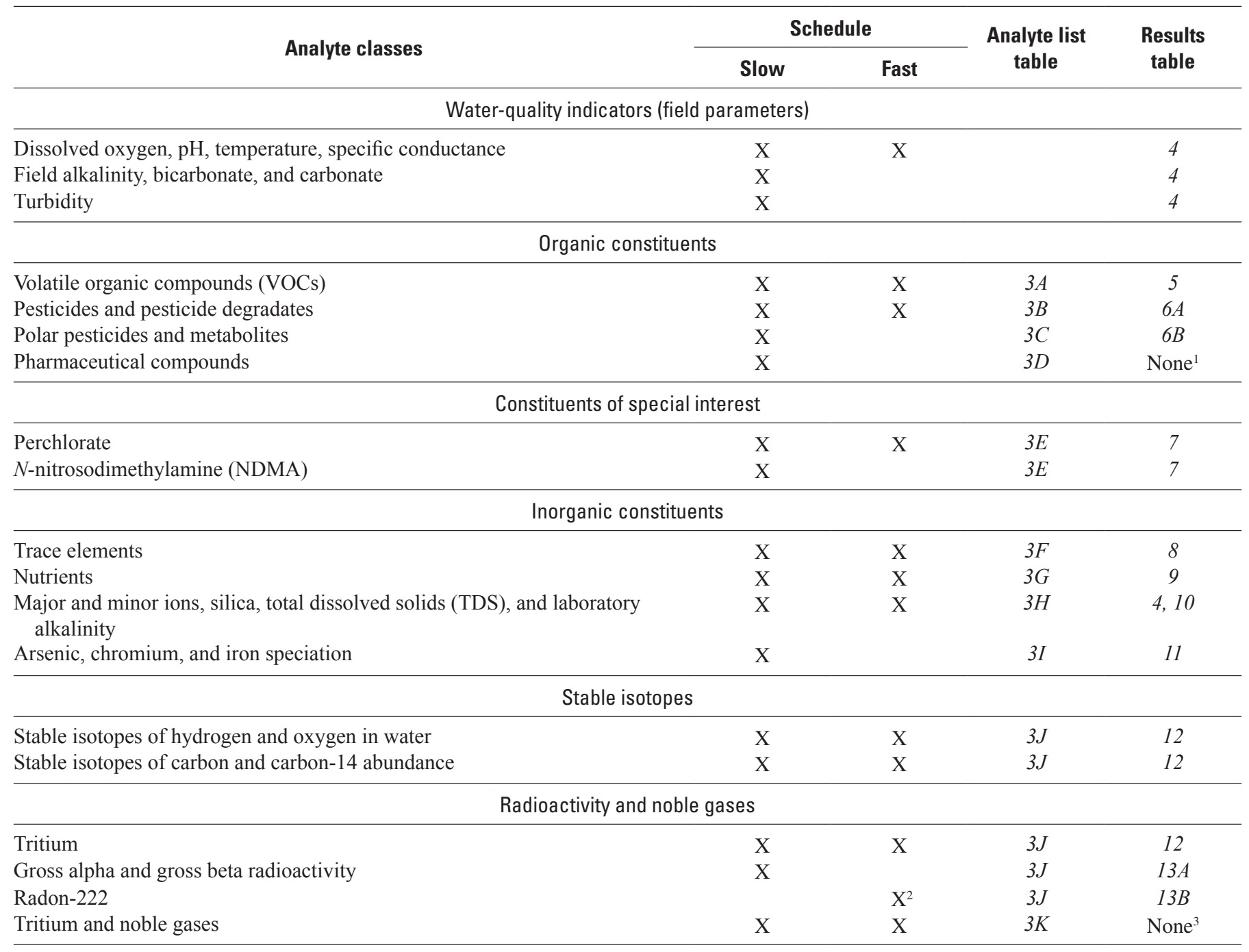

${ }^{1}$ Results for pharmaceutical compounds will be published in a subsequent publication.

${ }^{2}$ Radon-222 collected at five fast wells in the Gilroy study area as part of a special study.

${ }^{3}$ As of the publishing date of this data report, results for the analyses of noble gases and tritium by Lawrence Livermore National Laboratory (LLNL) were not available for publication. 
Table 3A. Volatile organic compounds (VOCs), primary uses or sources, comparative thresholds, and reporting information for the U.S. Geological Survey National Water Quality Laboratory Schedule 2020.

[The five-digit U.S. Geological Survey (USGS) parameter code is used to uniquely identify a specific constituent or property. Threshold type and threshold level as of November 17, 2008. Threshold type: Maximum contaminant level thresholds are listed as MCL-US when the MCL-US and MCL-CA are identical, and as MCL-CA when the MCL-CA is lower than the MCL-US or no MCL-US exists. HAL-US, U.S. Environmental Protection Agency lifetime health advisory level; MCL-CA, California Department of Public Health maximum contaminant level; MCL-US, U.S. Environmental Protection Agency maximum contaminant level; RSD5-US, U.S. Environmental Protection Agency risk specific dose at a risk factor of $10^{-5}$. This report contains CAS Registry Numbers ${ }^{\circledR}$, which are a Registered Trademark of the American Chemical Society. CAS recommends the verification of the CASRNs through CAS Client Services ${ }^{\mathrm{SM}}$. Abbreviations: CAS, Chemical Abstract Service; LRL, laboratory reporting level; D, detected in groundwater samples (table 5); na, not available; $\mu \mathrm{g} / \mathrm{L}$, micrograms per liter; - , not detected]

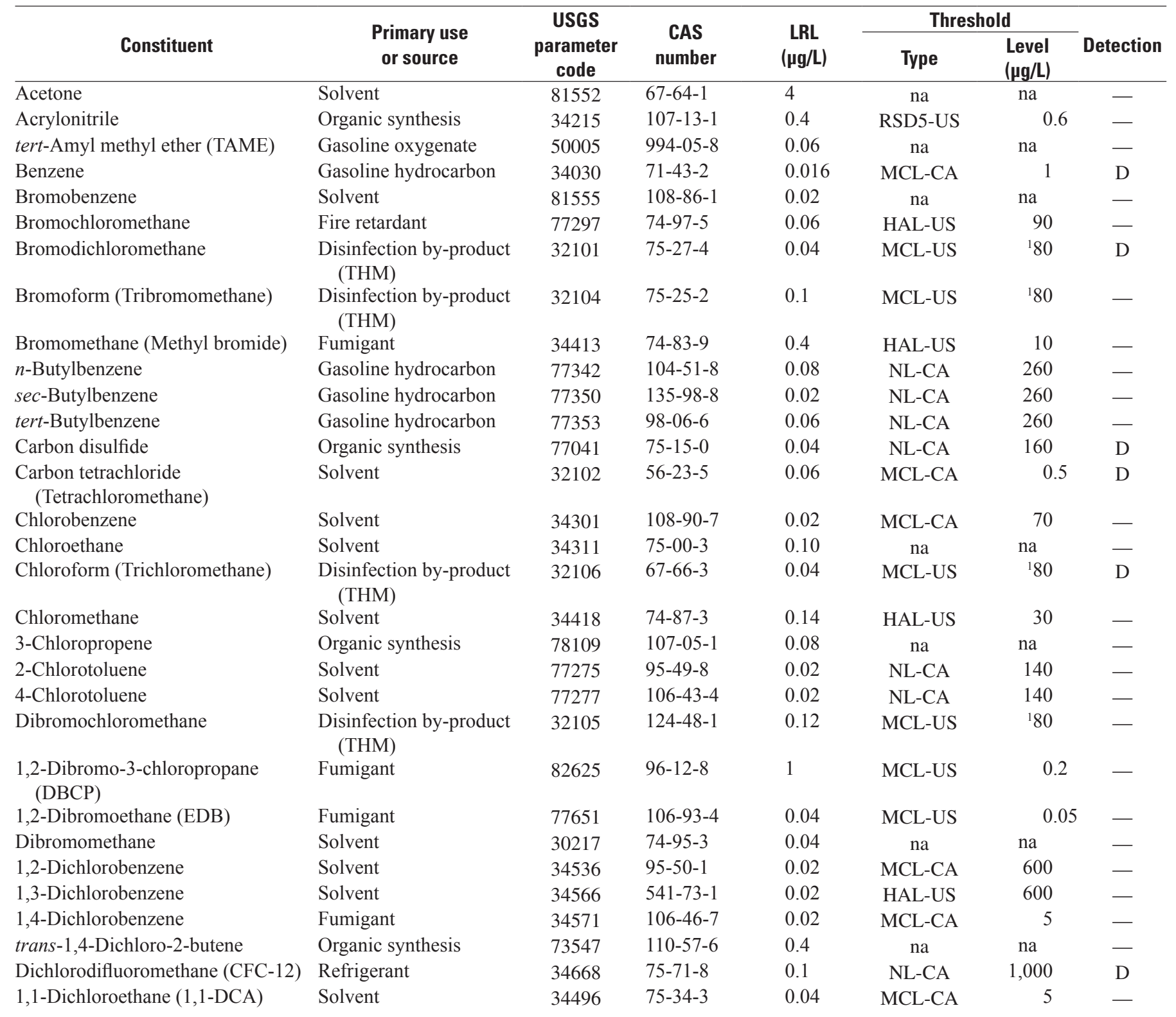


Table 3A. Volatile organic compounds (VOCs), primary uses or sources, comparative thresholds, and reporting information for the U.S. Geological Survey National Water Quality Laboratory Schedule 2020._Continued

[The five-digit U.S. Geological Survey (USGS) parameter code is used to uniquely identify a specific constituent or property. Threshold type and threshold level as of November 17, 2008. Threshold type: Maximum contaminant level thresholds are listed as MCL-US when the MCL-US and MCL-CA are identical, and as MCL-CA when the MCL-CA is lower than the MCL-US or no MCL-US exists. HAL-US, U.S. Environmental Protection Agency lifetime health advisory level; MCL-CA, California Department of Public Health maximum contaminant level; MCL-US, U.S. Environmental Protection Agency maximum contaminant level; RSD5-US, U.S. Environmental Protection Agency risk specific dose at a risk factor of $10^{-5}$. This report contains CAS Registry Numbers ${ }^{\circledR}$, which are a Registered Trademark of the American Chemical Society. CAS recommends the verification of the CASRNs through CAS Client Services ${ }^{\mathrm{SM}}$. Abbreviations: CAS, Chemical Abstract Service; LRL, laboratory reporting level; D, detected in groundwater samples (table 5); na, not available; $\mu \mathrm{g} / \mathrm{L}$, micrograms per liter;

-, not detected]

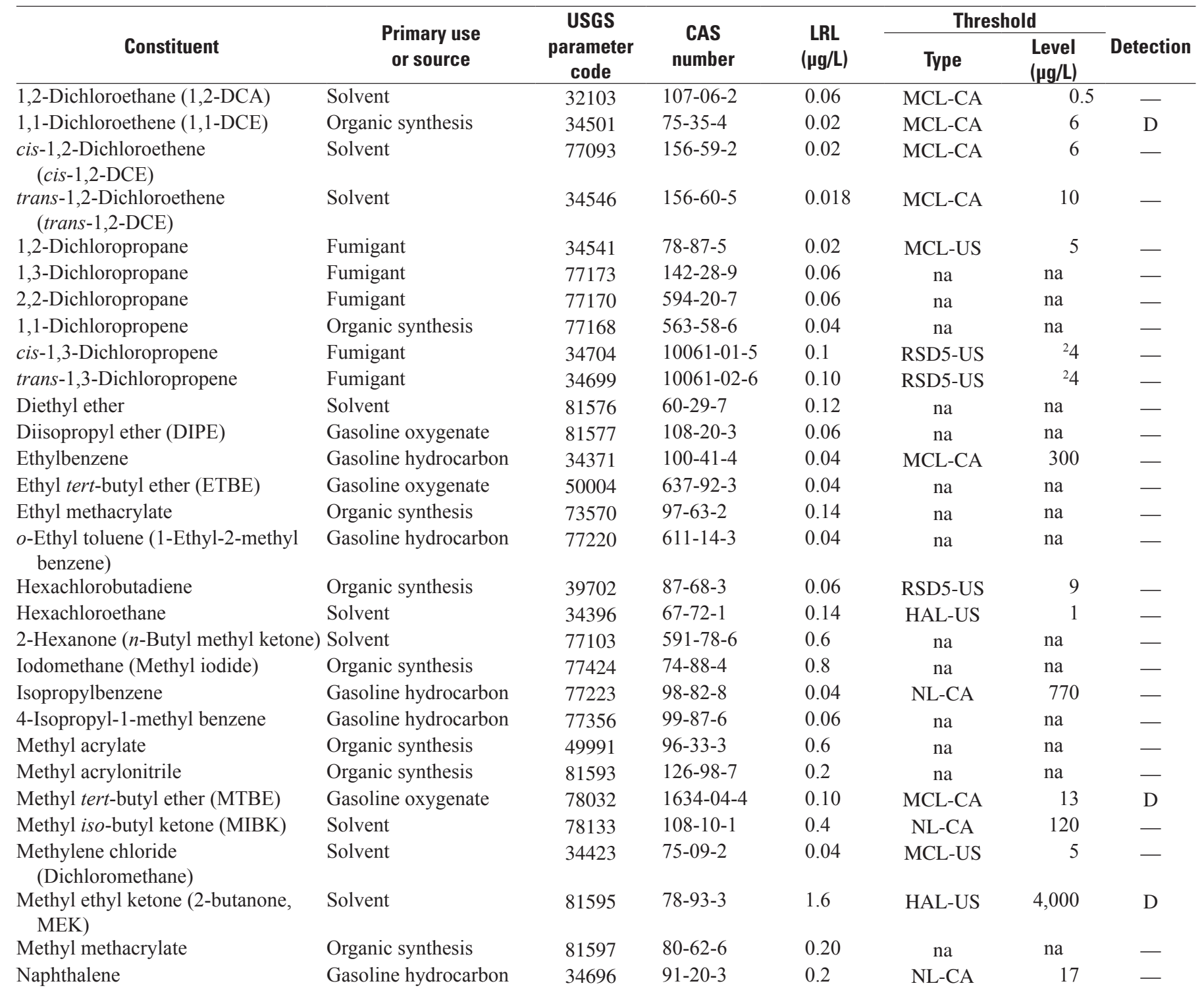


Table 3A. Volatile organic compounds (VOCs), primary uses or sources, comparative thresholds, and reporting information for the U.S. Geological Survey National Water Quality Laboratory Schedule 2020._Continued

[The five-digit U.S. Geological Survey (USGS) parameter code is used to uniquely identify a specific constituent or property. Threshold type and threshold level as of November 17, 2008. Threshold type: Maximum contaminant level thresholds are listed as MCL-US when the MCL-US and MCL-CA are identical, and as MCL-CA when the MCL-CA is lower than the MCL-US or no MCL-US exists. HAL-US, U.S. Environmental Protection Agency lifetime health advisory level; MCL-CA, California Department of Public Health maximum contaminant level; MCL-US, U.S. Environmental Protection Agency maximum contaminant level; RSD5-US, U.S. Environmental Protection Agency risk specific dose at a risk factor of $10^{-5}$. This report contains CAS Registry Numbers ${ }^{\circledR}$, which are a Registered Trademark of the American Chemical Society. CAS recommends the verification of the CASRNs through CAS Client Services ${ }^{\mathrm{SM}}$. Abbreviations: CAS, Chemical Abstract Service; LRL, laboratory reporting level; D, detected in groundwater samples (table 5); na, not available; $\mu \mathrm{g} / \mathrm{L}$, micrograms per liter;

-, not detected]

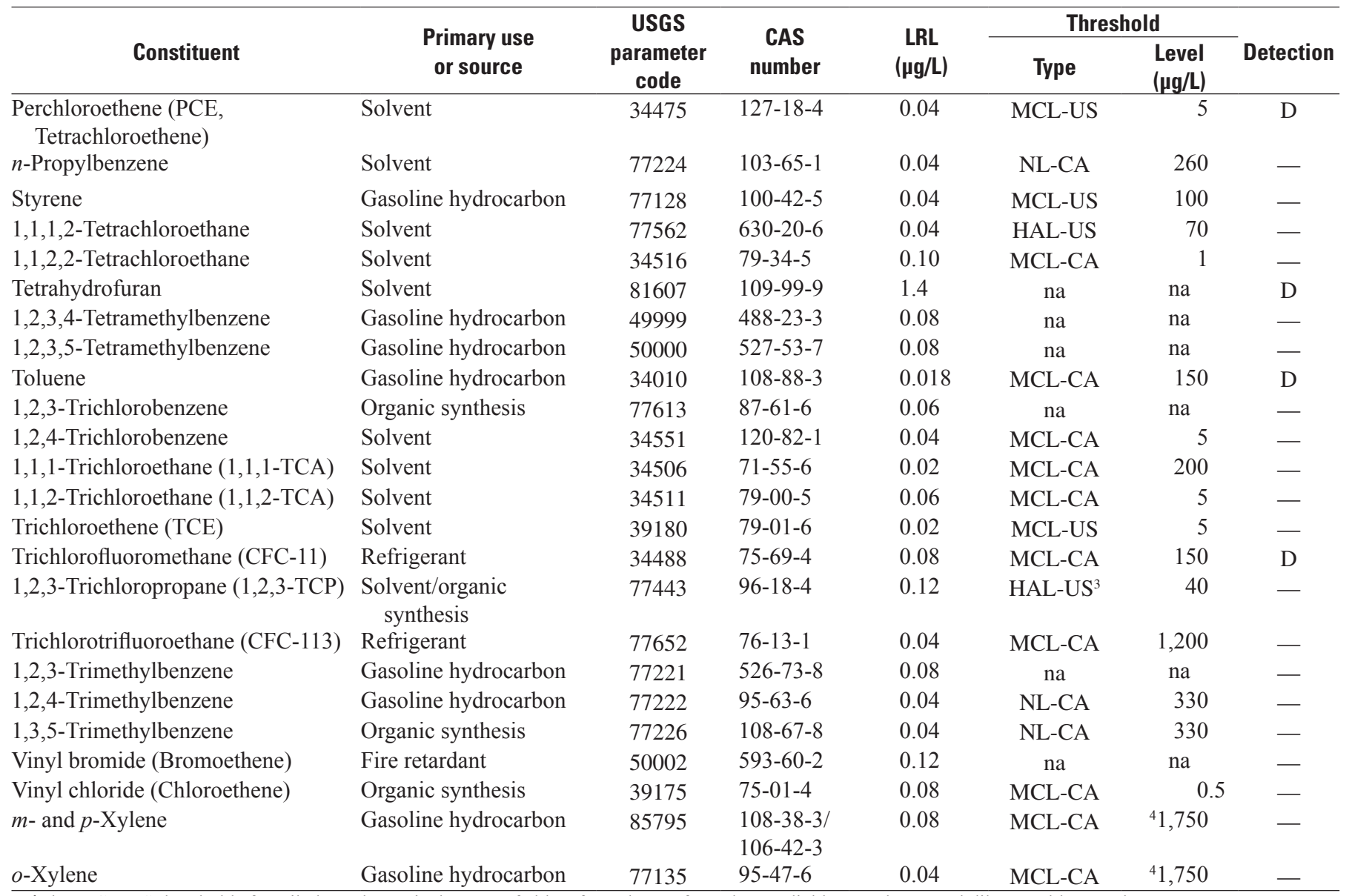

${ }^{1}$ The MCL-US thresholds for trihalomethanes is the sum of chloroform, bromoform, bromodichloromethane, and dibromochloromethane.

${ }^{2}$ The RSD5 threshold for 1,3-dichloropropene is the sum of its isomers (cis and trans).

${ }^{3}$ In earlier reports in this series, the NL-CA $(0.005 \mu \mathrm{g} / \mathrm{L})$ was used as the comparison threshold for 1,2,3-TCP.

${ }^{4}$ The MCL-CA thresholds for $m$ - and $p$-Xylene and $o$-Xylene is the sum all three xylene compounds. 
Table 3B. Pesticides and pesticide degradates, primary uses or sources, comparative thresholds, and reporting information for the U.S. Geological Survey National Water Quality Laboratory Schedule 2003.

[The five-digit U.S. Geological Survey (USGS) parameter code is used to uniquely identify a specific constituent or property. Threshold type and threshold level as of November 17, 2008. Threshold type: Maximum contaminant level thresholds are listed as MCL-US when the MCL-US and MCL-CA are identical, and as MCL-CA when the MCL-CA is lower than the MCL-US or no MCL-US exists. HAL-US, U.S. Environmental Protection Agency lifetime health advisory level; MCL-CA, California Department of Public Health maximum contaminant level; MCL-US, U.S. Environmental Protection Agency maximum contaminant level; RSD5-US, U.S. Environmental Protection Agency risk specific dose at a risk factor of $10^{-5}$. Abbreviations: CAS, Chemical Abstract Service; LRL, laboratory reporting level; D, detected in groundwater samples (table $6 A$ ); na, not available; $\mu \mathrm{g} / \mathrm{L}$, micrograms per liter; —, not detected]

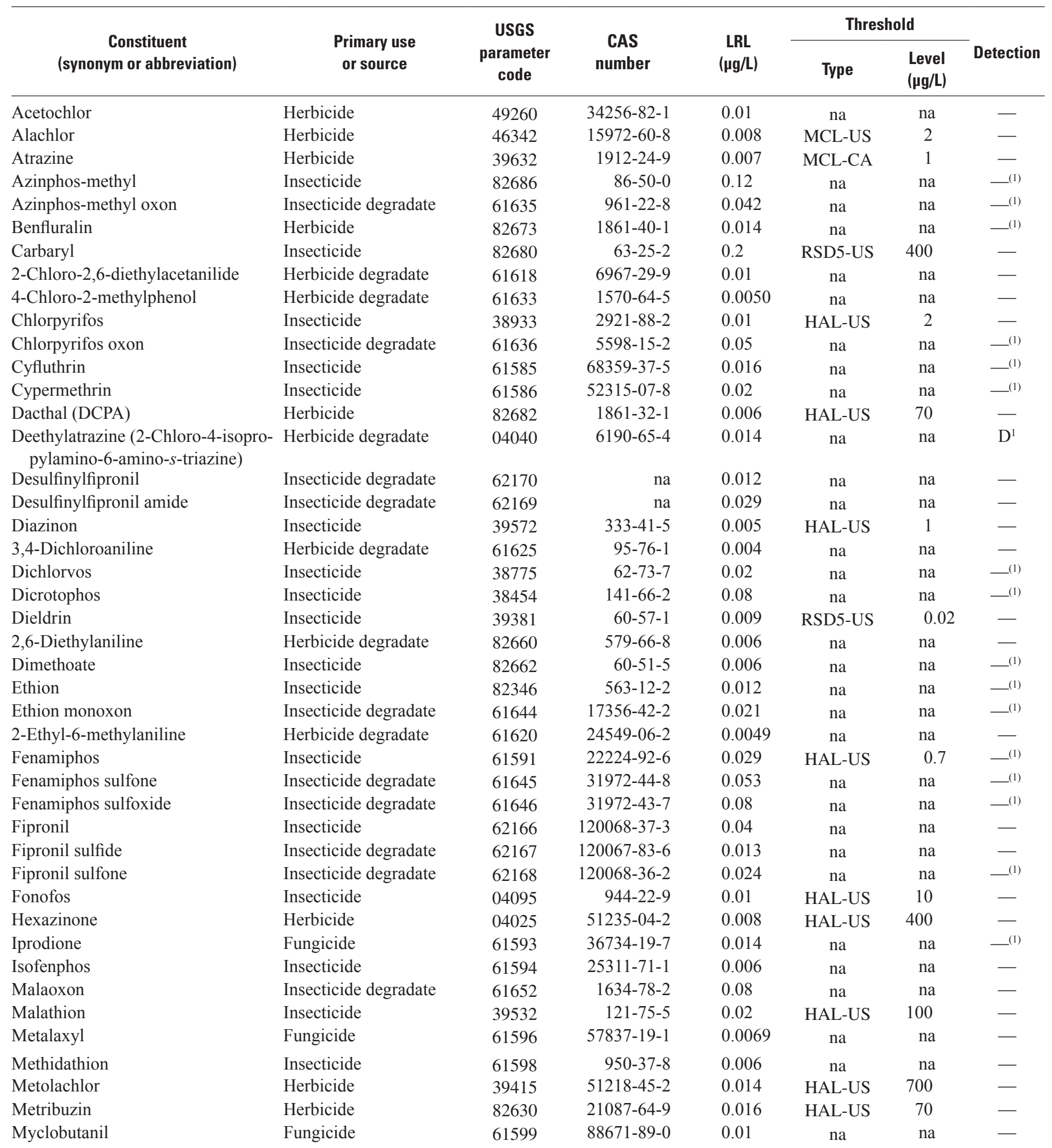


Table 3B. Pesticides and pesticide degradates, primary uses or sources, comparative thresholds, and reporting information for the U.S. Geological Survey National Water Quality Laboratory Schedule 2003.—Continued

[The five-digit U.S. Geological Survey (USGS) parameter code is used to uniquely identify a specific constituent or property. Threshold type and threshold level as of November 17, 2008. Threshold type: Maximum contaminant level thresholds are listed as MCL-US when the MCL-US and MCL-CA are identical, and as MCL-CA when the MCL-CA is lower than the MCL-US or no MCL-US exists. HAL-US, U.S. Environmental Protection Agency lifetime health advisory level; MCL-CA, California Department of Public Health maximum contaminant level; MCL-US, U.S. Environmental Protection Agency maximum contaminant level; RSD5-US, U.S. Environmental Protection Agency risk specific dose at a risk factor of 10 $0^{-5}$. Abbreviations: CAS, Chemical Abstract Service; LRL, laboratory reporting level; $\mathrm{D}$, detected in groundwater samples (table $6 \mathrm{~A}$ ); na, not available; $\mu \mathrm{g} / \mathrm{L}$, micrograms per liter; - , not detected]

\begin{tabular}{|c|c|c|c|c|c|c|c|}
\hline \multirow[b]{2}{*}{$\begin{array}{c}\text { Constituent } \\
\text { (synonym or abbreviation) }\end{array}$} & \multirow[b]{2}{*}{$\begin{array}{l}\text { Primary use } \\
\text { or source }\end{array}$} & \multirow{2}{*}{$\begin{array}{c}\text { USGS } \\
\text { parameter } \\
\text { code }\end{array}$} & \multirow[b]{2}{*}{$\begin{array}{c}\text { CAS } \\
\text { number }\end{array}$} & \multirow[b]{2}{*}{$\begin{array}{c}\text { LRL } \\
(\mu \mathrm{g} / \mathrm{L})\end{array}$} & \multicolumn{2}{|c|}{ Threshold } & \multirow[b]{2}{*}{ Detectior } \\
\hline & & & & & Type & $\begin{array}{l}\text { Level } \\
(\mu \mathrm{g} / \mathrm{L})\end{array}$ & \\
\hline Paraoxon-methyl & Insecticide degradate & 61664 & $950-35-6$ & 0.01 & na & na & —(1) \\
\hline Parathion-methyl & Insecticide & 82667 & $298-00-0$ & 0.008 & HAL-US & 1 & —(1) $^{(1)}$ \\
\hline Pendimethalin & Herbicide & 82683 & $40487-42-1$ & 0.012 & na & na & - \\
\hline Phorate oxon & Insecticide degradate & 61666 & $2600-69-3$ & 0.027 & na & na & - \\
\hline Phosmet & Insecticide & 61601 & $732-11-6$ & 0.2 & na & na & —(1) $^{(1)}$ \\
\hline Phosmet oxon & Insecticide degradate & 61668 & $3735-33-9$ & 0.0511 & na & na & 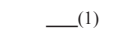 \\
\hline Prometon & Herbicide & 04037 & $1610-18-0$ & 0.012 & HAL-US & 100 & $\mathrm{D}$ \\
\hline Prometryn & Herbicide & 04036 & $7287-19-6$ & 0.0059 & na & na & - \\
\hline Terbufos & Insecticide & 82675 & $13071-79-9$ & 0.018 & HAL-US & 0.4 & —(1) \\
\hline Terbufos oxon sulfone & Insecticide degradate & 61674 & $56070-15-6$ & 0.045 & na & na & —(1) $^{(1)}$ \\
\hline Terbuthylazine & Herbicide & 04022 & $5915-41-3$ & 0.006 & na & na & - \\
\hline Tribufos & Defoliant & 61610 & $78-48-8$ & 0.035 & na & na & — $^{(1)}$ \\
\hline Trifluralin & Herbicide & 82661 & $1582-09-8$ & 0.012 & HAL-US & 10 & — $^{(1)}$ \\
\hline
\end{tabular}

${ }^{1}$ The median matrix-spike recovery was less than 70 percent. Low recoveries may indicate that the compound might not have been detected in some samples if it was present at very low concentrations. 
Table 3C. Polar pesticides and metabolites, primary uses or sources, comparative thresholds, and reporting information for the U.S. Geological Survey National Water Quality Laboratory Schedule 2060.

[The five-digit U.S. Geological Survey (USGS) parameter code is used to uniquely identify a specific constituent or property. Threshold and threshold values as of November 17, 2008. Threshold type: Maximum contaminant level thresholds are listed as MCL-US when the MCL-US and MCL-CA are identical, and as MCL-CA when the MCL-CA is lower than the MCL-US or no MCL-US exists. HAL-US, U.S. Environmental Protection Agency Lifetime Health Advisory; MCL-CA, California Department of Public Health maximum contaminant level; MCL-US, U.S. Environmental Protection Agency maximum contaminant level; RSD5-US, U.S. Environmental Protection Agency risk specific dose at a risk factor of 10-5. Abbreviations: CAS, Chemical Abstract Service; LRL, laboratory reporting level; IRL, interim reporting level; D, detected in groundwater samples (table 6B); na, not available; $\mu \mathrm{g} / \mathrm{L}$, micrograms per liter; - , not detected]

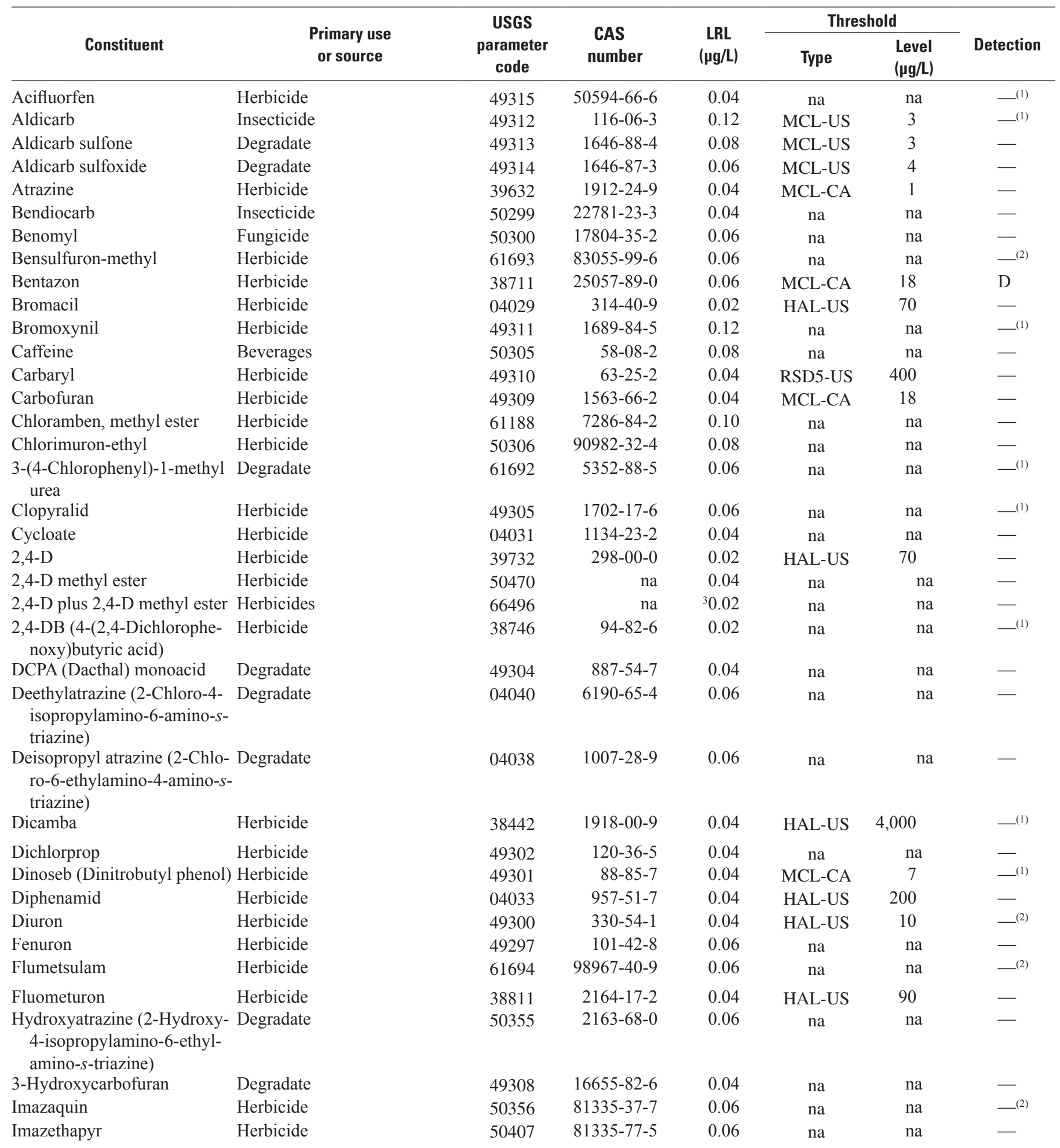


Table 3C. Polar pesticides and metabolites, primary uses or sources, comparative thresholds, and reporting information for the U.S. Geological Survey National Water Quality Laboratory Schedule 2060._Continued

[The five-digit U.S. Geological Survey (USGS) parameter code is used to uniquely identify a specific constituent or property. Threshold and threshold values as of November 17, 2008. Threshold type: Maximum contaminant level thresholds are listed as MCL-US when the MCL-US and MCL-CA are identical, and as MCL-CA when the MCL-CA is lower than the MCL-US or no MCL-US exists. HAL-US, U.S. Environmental Protection Agency Lifetime Health Advisory; MCL-CA, California Department of Public Health maximum contaminant level; MCL-US, U.S. Environmental Protection Agency maximum contaminant level; RSD5-US, U.S. Environmental Protection Agency risk specific dose at a risk factor of $10^{-5}$. Abbreviations: CAS, Chemical Abstract Service; LRL, laboratory reporting level; IRL, interim reporting level; $\mathrm{D}$, detected in groundwater samples (table $6 B$ ); na, not available; $\mu \mathrm{g} / \mathrm{L}$, micrograms per liter; - , not detected]

\begin{tabular}{|c|c|c|c|c|c|c|c|}
\hline \multirow[b]{2}{*}{ Constituent } & \multirow[b]{2}{*}{$\begin{array}{l}\text { Primary use } \\
\text { or source }\end{array}$} & \multirow{2}{*}{$\begin{array}{c}\text { USGS } \\
\text { parameter } \\
\text { code }\end{array}$} & \multirow[b]{2}{*}{$\begin{array}{l}\text { CAS } \\
\text { number }\end{array}$} & \multirow[b]{2}{*}{$\begin{array}{c}\text { LRL } \\
(\mu \mathrm{g} / \mathrm{L})\end{array}$} & \multicolumn{2}{|c|}{ Threshold } & \multirow[b]{2}{*}{ Detection } \\
\hline & & & & & Type & $\begin{array}{l}\text { Level } \\
(\mu \mathrm{g} / \mathrm{L})\end{array}$ & \\
\hline Imidacloprid & Insecticide & 61695 & $138261-41-3$ & 0.06 & na & na & - \\
\hline Linuron & Herbicide & 38478 & $330-55-2$ & 0.04 & na & na & - \\
\hline $\begin{array}{l}\text { MCPA (2-Methyl-4-chloro- } \\
\text { phenoxyacetic acid) }\end{array}$ & Herbicide & 38482 & 94-74-6 & 0.04 & HAL-US & 30 & - \\
\hline Metalaxyl & Fungicide & 50359 & $57837-19-1$ & 0.04 & na & na & - \\
\hline Methiocarb & Insecticide & 38501 & $2032-65-7$ & 0.04 & na & na & - \\
\hline Methomyl & Insecticide & 49296 & $16752-77-5$ & 0.12 & HAL-US & 200 & - \\
\hline Metsulfuron methyl & Herbicide & 61697 & $74223-64-6$ & ${ }^{1} 0.14$ & na & na & - \\
\hline Neburon & Herbicide & 49294 & $555-37-3$ & 0.02 & na & na & - \\
\hline Nicosulfuron & Herbicide & 50364 & 111991-09-4 & 0.10 & na & na & —(2) $^{(2)}$ \\
\hline Picloram & Herbicide & 49291 & 1918-02-01 & 0.12 & MCL-US & 500 & — $^{(1)}$ \\
\hline Propham & Herbicide & 49236 & $122-42-9$ & 0.04 & HAL-US & 100 & - \\
\hline Propiconazole & Fungicide & 50471 & $60207-90-1$ & 0.04 & na & na & - \\
\hline Propoxur & Insecticide & 38538 & 114-26-1 & 0.06 & na & na & - \\
\hline Siduron & Herbicide & 38548 & $1982-49-6$ & 0.04 & na & na & - \\
\hline Sulfometuron-methyl & Herbicide & 50337 & $74222-97-2$ & 0.06 & na & na & —(2) $^{(2)}$ \\
\hline Tebuthiuron & Herbicide & 82670 & $34014-18-1$ & 0.06 & HAL-US & 500 & - \\
\hline Terbacil & Herbicide & 04032 & $5902-51-2$ & 0.04 & HAL-US & 90 & - \\
\hline Triclopyr & Herbicide & 49235 & $55335-06-3$ & 0.08 & na & na & - \\
\hline
\end{tabular}

${ }^{1}$ Value is an IRL rather than an LRL.

${ }^{2}$ The median matrix-spike recovery was less than 70 percent. Low recoveries may indicate that the compound might not have been detected in some samples if it was present at very low concentrations.

${ }^{3}$ The median laboratory matrix-spike recovery was greater than 130 percent. High recoveries may indicate that reported values could be higher than what is in the sample. 
Table 3D. Pharmaceutical compounds, primary uses or sources, comparative thresholds, and reporting information for the U.S. Geological Survey National Water Quality Laboratory Schedule 2080.

[The five-digit U.S. Geological Survey (USGS) parameter code is used to uniquely identify a specific constituent or property. The California Groundwater Ambient Monitoring and Assessment (GAMA) program uses more conservative reporting limits for the pharmaceutical compounds than recommended by the USGS National Water Quality Laboratory. For albuterol, carbamazepine, codeine, dehydronifedipine, diltiazem, sulfamethoxazole, thiabendazole, trimethoprim, and warfarin, the MDL corresponds to the long-term method detection limit determined by the USGS Branch of Quality Systems in October 2007 (BQS LT-MDL). For acetaminophen, caffeine, cotinine, diphenhydramine, and xanthine, the MDL corresponds to the study reporting levels determined from assessment of quality-control data associated with GAMA samples collected from May 2004 through September 2007 (GAMA SRL). The GAMA SRLs are higher than the BQS LT-MDL for those compounds. Detections reported by the USGS National Water Quality Laboratory with concentrations lower than the BQS LT-MDL or GAMA SRL are reported as non-detections by the GAMA program. Results for pharmaceutical compounds from the GAMA SCI study unit will be included in a subsequent report. Abbreviations: CAS, Chemical Abstract Service; MDL, method detection limit; $\mu \mathrm{g} / \mathrm{L}$, micrograms per liter; na, not available]

\begin{tabular}{|c|c|c|c|c|c|c|}
\hline \multirow[b]{2}{*}{ Constituent } & \multirow{2}{*}{$\begin{array}{c}\text { Primary use } \\
\text { or source }\end{array}$} & \multirow{2}{*}{$\begin{array}{c}\text { USGS } \\
\text { parameter } \\
\text { code }\end{array}$} & \multirow{2}{*}{$\begin{array}{c}\text { CAS } \\
\text { number }\end{array}$} & \multirow[b]{2}{*}{$\begin{array}{l}\text { MDL } \\
(\mu \mathrm{g} / \mathrm{L})\end{array}$} & \multicolumn{2}{|c|}{ Threshold } \\
\hline & & & & & Type & $\begin{array}{l}\text { Level } \\
\text { ( } \mu \mathrm{g} / \mathrm{L} \text { ) }\end{array}$ \\
\hline Acetaminophen & Analgesic & 62000 & $103-90-2$ & 0.60 & na & na \\
\hline Albuterol & Anti-inflammatory; bronchodilator & 62020 & 18559-94-9 & 0.03 & na & na \\
\hline Caffeine & Stimulant & 50305 & $58-08-2$ & 0.40 & na & na \\
\hline Codeine & Opiod narcotic & 62003 & $76-57-3$ & 0.02 & na & na \\
\hline Cotinine & Nicotine metabolite & 62005 & 486-56-6 & 0.03 & na & na \\
\hline Dehydronifedipine & Antianginal metabolite & 62004 & $67035-22-7$ & 0.03 & na & na \\
\hline Diltiazem & Antianginal; antihypertensive & 62008 & $42399-41-7$ & 0.02 & na & na \\
\hline Diphenhydramine & Antihistamine & 62796 & $58-73-1$ & 0.03 & na & na \\
\hline Warfarin & Anticoagulant & 62024 & 81-81-2 & 0.03 & na & na \\
\hline
\end{tabular}

Table 3E. Constituents of special interest (perchlorate and $\mathrm{N}$-nitrosodimethylamine [NDMA]), primary uses or sources, comparative thresholds, and reporting information for Weck Laboratories, Inc. analyses.

[The five-digit U.S. Geological Survey (USGS) parameter code is used to uniquely identify a specific constituent or property. Threshold type and threshold level as of November 17, 2008. Threshold type: MCL-CA, California Department of Public Health maximum contaminant level; NL-CA, California Department of Public Health notification level. Abbreviations: CAS, Chemical Abstract Service; MRL, minimum reporting level; D, detected in groundwater samples (table 7); $\mu \mathrm{g} / \mathrm{L}$, micrograms per liter; - , not detected]

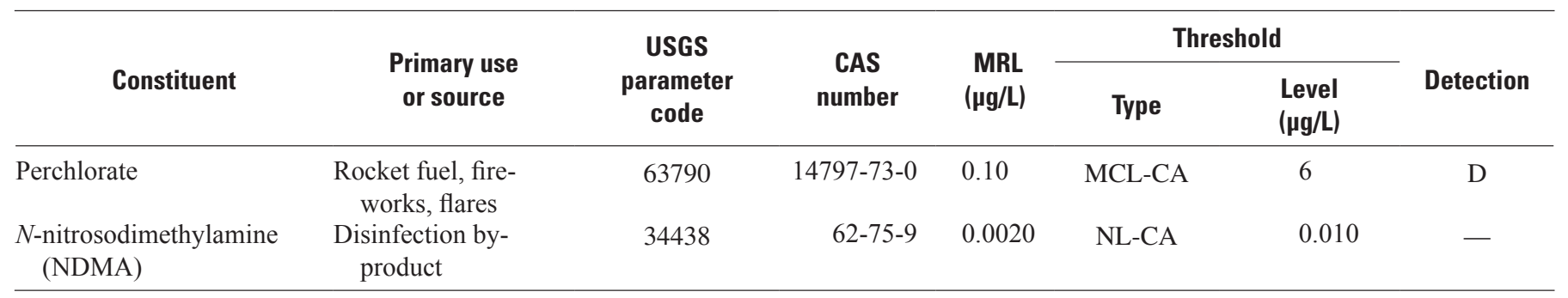


Table 3F. Trace elements, comparative thresholds, and reporting information for the U.S. Geological Survey National Water Quality Laboratory Schedule 1948.

[The five-digit U.S. Geological Survey (USGS) parameter code is used to uniquely identify a specific constituent or property. Threshold type and threshold level as of November 17, 2008. Threshold type: Maximum contaminant level thresholds are listed as MCL-US when the MCL-US and MCL-CA are identical, and as MCL-CA when the MCL-CA is lower than the MCL-US or no MCL-US exists. AL-US, U.S. Environmental Protection Agency action level; HAL-US, U.S. Environmental Protection Agency lifetime health advisory level; MCL-CA, California Department of Public Health maximum contaminant level; MCL-US, U.S. Environmental Protection Agency maximum contaminant level; NL-CA, California Department of Public Health notification level; SMCL-CA, California Department of Public Health secondary maximum contaminant level. Abbreviations: CAS, Chemical Abstract Service; LRL, laboratory reporting level; SRL, study reporting limit; D, detected in groundwater samples (table 8); na, not available; $\mu \mathrm{g} / \mathrm{L}$, micrograms per liter; -, not detected]

\begin{tabular}{|c|c|c|c|c|c|c|}
\hline \multirow[b]{2}{*}{ Constituent } & \multirow{2}{*}{$\begin{array}{c}\text { USGS } \\
\text { parameter } \\
\text { code }\end{array}$} & \multirow{2}{*}{$\begin{array}{c}\text { CAS } \\
\text { number }\end{array}$} & \multirow{2}{*}{$\begin{array}{c}\text { LRL/SRL } \\
(\mu \mathrm{g} / \mathrm{L})\end{array}$} & \multicolumn{2}{|c|}{ Threshold } & \multirow[b]{2}{*}{ Detection } \\
\hline & & & & Type & $\begin{array}{l}\text { Level } \\
\text { ( } \mu \mathrm{g} / \mathrm{L})\end{array}$ & \\
\hline Aluminum & 01106 & $7429-90-5$ & 4 & MCL-CA & 1,000 & $\mathrm{D}$ \\
\hline Antimony & 01095 & $7440-36-0$ & 0.04 & MCL-US & 6 & $\mathrm{D}$ \\
\hline Arsenic & 01000 & $7440-38-2$ & 0.06 & MCL-US & 10 & $\mathrm{D}$ \\
\hline Barium & 01005 & $7440-39-3$ & 0.4 & MCL-CA & 1,000 & $\mathrm{D}$ \\
\hline Beryllium & 01010 & $7440-41-7$ & 0.02 & MCL-US & 4 & $\mathrm{D}$ \\
\hline Boron & 01020 & $7440-42-8$ & 4 & NL-CA & 1,000 & $\mathrm{D}$ \\
\hline Cadmium & 01025 & $7440-43-9$ & 0.02 & MCL-US & 5 & $\mathrm{D}$ \\
\hline Chromium & 01030 & $7440-47-3$ & 0.12 & MCL-CA & 50 & $\mathrm{D}$ \\
\hline Cobalt & 01035 & $7440-48-4$ & 0.02 & na & na & $\mathrm{D}$ \\
\hline Copper & 01040 & $7440-50-8$ & 1 & AL-US & 1,300 & $\mathrm{D}$ \\
\hline Iron & 01046 & $7439-89-6$ & 4 & SMCL-CA & 300 & $\mathrm{D}$ \\
\hline Lead & 01049 & 7439-92-1 & 0.06 & AL-US & 15 & $\mathrm{D}$ \\
\hline Lithium & 01130 & $7439-93-2$ & 1 & na & na & $\mathrm{D}$ \\
\hline Manganese & 01056 & $7439-96-5$ & 0.2 & SMCL-CA & 50 & $\mathrm{D}$ \\
\hline Molybdenum & 01060 & $7439-98-7$ & 0.02 & HAL-US & 40 & $\mathrm{D}$ \\
\hline Nickel & 01065 & $7440-02-0$ & 0.12 & MCL-CA & 100 & $\mathrm{D}$ \\
\hline Selenium & 01145 & $7782-49-2$ & 0.06 & MCL-US & 50 & $\mathrm{D}$ \\
\hline Silver & 01075 & $7440-22-4$ & 0.008 & SMCL-CA & 100 & $\mathrm{D}$ \\
\hline Strontium & 01080 & $7440-24-6$ & 0.8 & HAL-US & 4,000 & $\mathrm{D}$ \\
\hline Thallium & 01057 & $7440-28-0$ & 0.04 & MCL-US & 2 & - \\
\hline Tungsten & 01155 & $7440-33-7$ & 0.02 & na & na & $\mathrm{D}$ \\
\hline Uranium & 22703 & 7440-61-1 & 0.006 & MCL-US & 30 & $\mathrm{D}$ \\
\hline Vanadium & 01085 & $7440-62-2$ & 0.16 & NL-CA & 50 & $\mathrm{D}$ \\
\hline Zinc & 01090 & $7440-66-6$ & 2 & SMCL-CA $^{1}$ & 5,000 & $\mathrm{D}$ \\
\hline
\end{tabular}

${ }^{1}$ The secondary maximum contaminant level for zinc is listed as SMCL-CA since SMCLs established by California Department of Public Health are used in this report for all constituents that have SMCL-CA values. 
Table 3G. Nutrients, comparative thresholds, and reporting information for the U.S. Geological Survey National Water Quality Laboratory Schedule 2755.

[The five-digit U.S. Geological Survey (USGS) parameter code is used to uniquely identify a specific constituent or property. Threshold type and threshold level as of November 17, 2008. Threshold type: Maximum contaminant level thresholds are listed as MCL-US when the MCL-US and MCL-CA are identical, and as MCL-CA when the MCL-CA is lower than the MCL-US or no MCL-US exists. HAL-US, U.S. Environmental Protection Agency lifetime health advisory level; MCL-US, U.S. Environmental Protection Agency maximum contaminant level. Abbreviations: CAS, Chemical Abstract Service; LRL, laboratory reporting level; D, detected in groundwater samples (table 9); na, not available; mg/L, milligrams per liter]

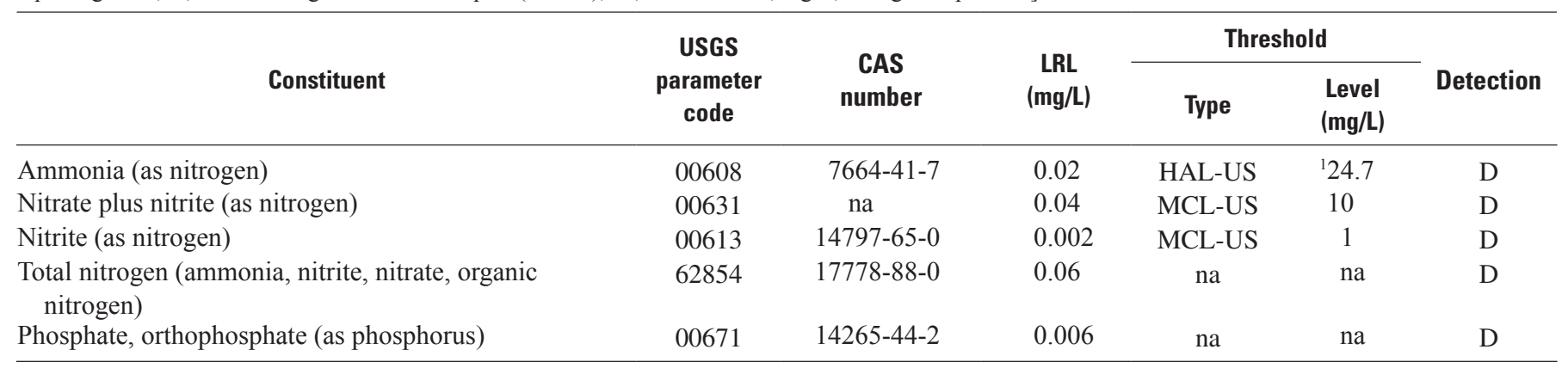

${ }^{1}$ The HAL-US is $30 \mathrm{mg} / \mathrm{L}$ "as ammonia." To facilitate comparson to the analytical results, we have converted and reported this HAL-US as $24.7 \mathrm{mg} / \mathrm{L}$ "as nitrogen."

Table 3H. Major and minor ions, silica, total dissolved solids (TDS), and alkalinity, comparative thresholds, and reporting information for the U.S. Geological Survey National Water Quality Laboratory Schedule 1948.

[The five-digit U.S. Geological Survey (USGS) parameter code is used to uniquely identify a specific constituent or property. Threshold type and threshold level as of November 17, 2008. Threshold type: Maximum contaminant level thresholds are listed as MCL-US when the MCL-US and MCL-CA are identical, and as MCL-CA when the MCL-CA is lower than the MCL-US or no MCL-US exists. MCL-CA, California Department of Public Health maximum contaminant level; SMCL-CA, California Department of Public Health secondary maximum contaminant level. Abbreviations: CAS, Chemical Abstract Service; LRL, laboratory reporting level; D, detected in groundwater samples (table10); na, not available; mg/L, milligrams per liter]

\begin{tabular}{|c|c|c|c|c|c|c|}
\hline \multirow[b]{2}{*}{ Constituent } & \multirow{2}{*}{$\begin{array}{c}\text { USGS } \\
\text { parameter } \\
\text { code }\end{array}$} & \multirow{2}{*}{$\begin{array}{c}\text { CAS } \\
\text { number }\end{array}$} & \multirow{2}{*}{$\begin{array}{c}\text { LRL } \\
(\mathrm{mg} / \mathrm{L})\end{array}$} & \multicolumn{2}{|c|}{ Threshold } & \multirow[b]{2}{*}{ Detection } \\
\hline & & & & Type & $\begin{array}{l}\text { Level } \\
\text { (mg/L) }\end{array}$ & \\
\hline Calcium & 00915 & $7440-70-2$ & 0.02 & na & na & $\mathrm{D}$ \\
\hline Chloride & 00940 & $16887-00-6$ & 0.12 & SMCL-CA & ${ }^{1} 250(500)$ & $\mathrm{D}$ \\
\hline Fluoride & 00950 & $16984-48-8$ & 0.08 & MCL-CA & 2 & $\mathrm{D}$ \\
\hline Magnesium & 00925 & $7439-95-4$ & 0.012 & na & na & $\mathrm{D}$ \\
\hline Potassium & 00935 & 7440-09-7 & 0.06 & na & na & $\mathrm{D}$ \\
\hline Silica (as $\mathrm{SiO}_{2}$ ) & 00955 & $7631-86-9$ & 0.02 & na & na & $\mathrm{D}$ \\
\hline Sodium & 00930 & $7440-23-5$ & 0.12 & na & na & $\mathrm{D}$ \\
\hline Sulfate & 00945 & $14808-79-8$ & 0.18 & SMCL-CA & ${ }^{1} 250(500)$ & $\mathrm{D}$ \\
\hline Residue on evaporation (total dissolved solids, TDS) & 70300 & na & 10 & SMCL-CA & ${ }^{1} 500(1,000)$ & $\mathrm{D}$ \\
\hline
\end{tabular}

${ }^{1}$ The recommended SMCL-CA thresholds for chloride, sulfate, and TDS are listed with the upper SMCL-CA thresholds in parentheses.

${ }^{2}$ Laboratory alkalinity results are presented in table 4. 
Table 3l. Arsenic, chromium, and iron species, comparative thresholds, and reporting information for the U.S. Geological Survey Trace Metal Laboratory, Boulder, Colorado, analyses.

[The five-digit U.S. Geological Survey (USGS) parameter code is used to uniquely identify a specific constituent or property. Threshold type and threshold level as of November 17, 2008. Threshold type: Maximum contaminant level thresholds are listed as MCL-US when the MCL-US and MCL-CA are identical, and as MCL-CA when the MCL-CA is lower than the MCL-US or no MCL-US exists. MCL-CA, California Department of Public Health maximum contaminant level; MCL-US, U.S. Environmental Protection Agency maximum contaminant level; SMCL-US, U.S. Environmental Protection Agency secondary maximum contaminant level. Abbreviations: CAS, Chemical Abstract Service; MDL, method detection limit; na, not available; $\mu \mathrm{g} / \mathrm{L}$, micrograms per liter; D, detected in groundwater samples (table 11)]

\begin{tabular}{|c|c|c|c|c|c|c|}
\hline \multirow[b]{2}{*}{ Constituent } & \multirow{2}{*}{$\begin{array}{c}\text { USGS } \\
\text { parameter } \\
\text { code }\end{array}$} & \multirow{2}{*}{$\begin{array}{c}\text { CAS } \\
\text { number }\end{array}$} & \multirow{2}{*}{$\begin{array}{l}\text { MDL } \\
(\mu \mathrm{g} / \mathrm{L})\end{array}$} & \multicolumn{2}{|c|}{ Threshold } & \multirow[b]{2}{*}{ Detection } \\
\hline & & & & Type & $\begin{array}{l}\text { Level } \\
\text { ( } \mu \mathrm{g} / \mathrm{L})\end{array}$ & \\
\hline Arsenic(III) & 99034 & $22569-72-8$ & 1 & na & na & $\mathrm{D}$ \\
\hline Arsenic (total) & 99033 & $7440-38-2$ & 0.5 & MCL-US & 10 & $\mathrm{D}$ \\
\hline Chromium(VI) & 01032 & $18540-29-9$ & 1 & na & na & $\mathrm{D}$ \\
\hline Chromium (total) & 01030 & $7440-47-3$ & 1 & MCL-CA & 50 & $\mathrm{D}$ \\
\hline $\operatorname{Iron}(\mathrm{II})$ & 01047 & $7439-89-6$ & 2 & na & na & $\mathrm{D}$ \\
\hline Iron (total) & 01046 & $7439-89-6$ & 2 & SMCL-US & 300 & $\mathrm{D}$ \\
\hline
\end{tabular}

Table 3J. Isotopic and radioactive constituents, comparative thresholds, and reporting information for laboratory analyses.

[The five-digit U.S. Geological Survey (USGS) parameter code is used to uniquely identify a specific constituent or property. Stable isotope ratios are reported in the standard delta notation $(\delta)$, the ratio of a heavier isotope to a more common lighter isotope of that element, relative to a standard reference material. Threshold type and threshold level as of November 17, 2008. Threshold type: Maximum contaminant level thresholds are listed as MCL-US when the MCLUS and MCL-CA are identical, and as MCL-CA when the MCL-CA is lower than the MCL-US or no MCL-US exists. MCL-CA, California Department of Public Health maximum contaminant level; MCL-US, U.S. Environmental Protection Agency maximum contaminant level. Abbreviations: CAS, Chemical Abstract Service; CSU, combined standard uncertainty; $\mathrm{ssL}_{\mathrm{C}}$, sample-specific critical level; MRL, minimum reporting level; MU, method uncertainty; na, not available; pCi/L, picocuries per liter; 2SCU, 2-sigma combined uncertainty; D, detected in groundwater samples (tables 12 and 13]

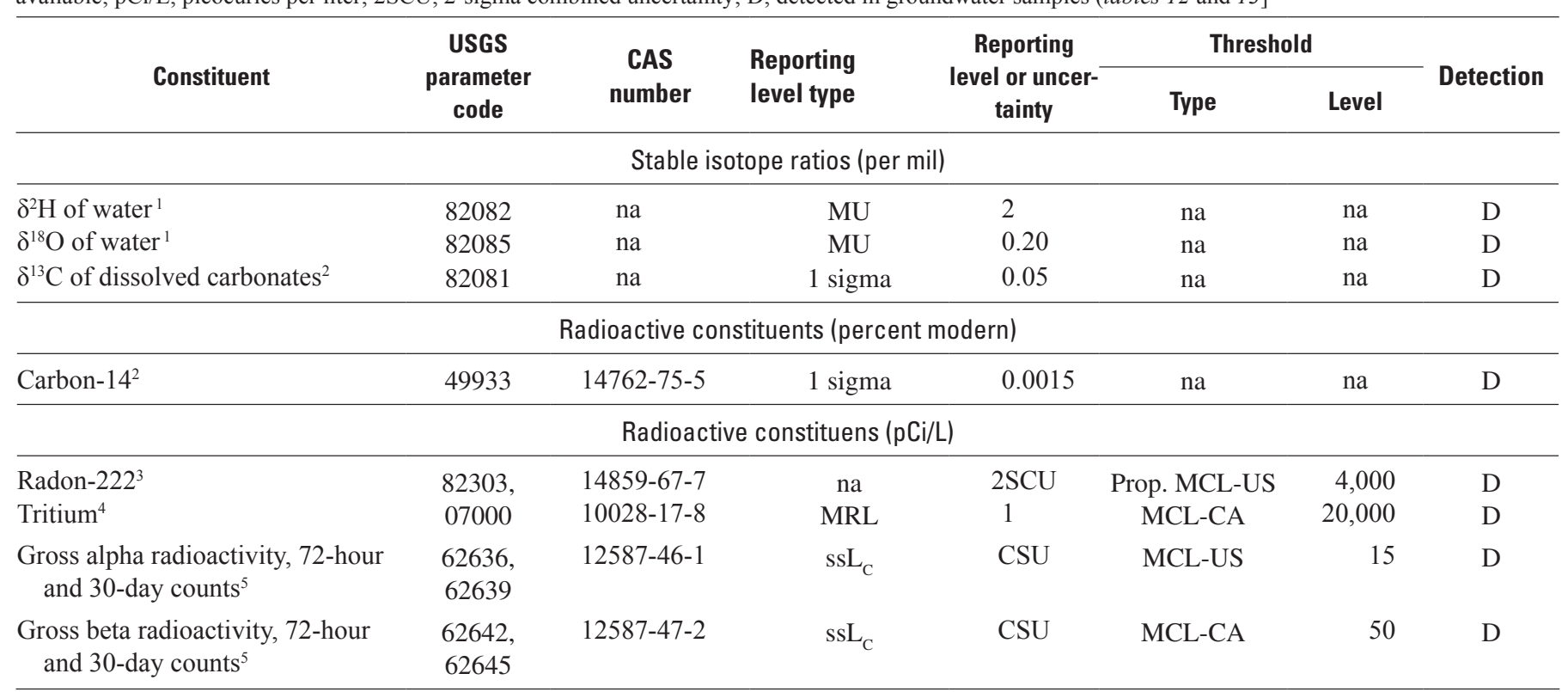

${ }^{1}$ U.S. Geological Survey Stable Isotope Laboratory, Reston, Virginia.

${ }^{2}$ Woods Hole Oceanographic Institution, National Ocean Sciences Accelerator Mass Spectrometry Facility (NOSAMS) (contract laboratory).

${ }^{3}$ U.S. Geological Survey National Water Quality Laboratory.

${ }^{4}$ U.S. Geological Survey Stable Isotope and Tritium Laboratory, Menlo Park, California.

${ }^{5}$ Eberline Analytical Services (contract laboratory). 
Table 3K. Noble gases and tritium, comparison thresholds, and reporting information for the Lawrence Livermore National Laboratory analyses.

[The five-digit U.S. Geological Survey (USGS) parameter code is used to uniquely identify a specific constituent or property. Threshold type and threshold values as of November 17, 2008. Threshold type: Maximum contaminant level thresholds are listed as MCL-US when the MCL-US and MCL-CA are identical, and as MCL-CA when the MCL-CA is lower than the MCL-US or no MCL-US exists. MCL-CA, California Department of Public Health maximum contaminant level. Abbreviations: CAS, Chemical Abstract Service; MU, method uncertainty; na, not available; $\mathrm{cm}^{3} \mathrm{STP} / \mathrm{g}$, cubic centimeters of gas at standard temperature and pressure per gram of water; $\mathrm{pCi} / \mathrm{L}$, picocuries per liter]

\begin{tabular}{|c|c|c|c|c|c|c|c|}
\hline \multirow[b]{2}{*}{ Constituent } & \multirow{2}{*}{$\begin{array}{c}\text { USGS } \\
\text { parameter } \\
\text { code }\end{array}$} & \multirow{2}{*}{$\begin{array}{c}\text { CAS } \\
\text { number }\end{array}$} & \multirow{2}{*}{$\begin{array}{c}\text { MU } \\
\text { (percent) }\end{array}$} & \multirow{2}{*}{$\begin{array}{l}\text { Reporting } \\
\text { units }\end{array}$} & \multicolumn{2}{|c|}{ Threshold } & \multirow[b]{2}{*}{ Detection } \\
\hline & & & & & Type & $\begin{array}{l}\text { Level } \\
\text { (pCi/L) }\end{array}$ & \\
\hline Helium-3/Helium-4 & 61040 & $\mathrm{na} / 7440-59-7$ & 0.75 & atom ratio & na & na & na \\
\hline Argon & 85563 & 7440-37-1 & 2 & $\mathrm{~cm}^{3} \mathrm{STP} / \mathrm{g}$ & na & na & na \\
\hline Helium-4 & 85561 & $7440-59-7$ & 2 & $\mathrm{~cm}^{3} \mathrm{STP} / \mathrm{g}$ & na & na & na \\
\hline Krypton & 85565 & 7439-90-9 & 2 & $\mathrm{~cm}^{3} \mathrm{STP} / \mathrm{g}$ & na & na & na \\
\hline Neon & 61046 & 7440-01-09 & 2 & $\mathrm{~cm}^{3} \mathrm{STP} / \mathrm{g}$ & na & na & na \\
\hline Xenon & 85567 & $7440-63-3$ & 2 & $\mathrm{~cm}^{3} \mathrm{STP} / \mathrm{g}$ & na & na & na \\
\hline Tritium & 07000 & $10028-17-8$ & 1 & $\mathrm{pCi} / \mathrm{L}$ & MCL-CA & 20,000 & na \\
\hline
\end{tabular}


Table 4. Water-quality indicators (field parameters) in samples collected for the South Coast Interior Basins Groundwater Ambient Monitoring and Assessment (GAMA) study unit, California, August to December 2008.

[The five-digit U.S. Geological Survey (USGS) parameter code below the constituent name is used to uniquely identify a specific constituent or property. GAMA identification number: LIV, Livermore study area grid well; LIVU, Livermore study area understanding well; GIL, Gilroy study area grid well; GILU, Gilroy study area understanding well; CUY, Cuyama study area grid well; CUYU, Cuyama study area understanding well. Threshold type and threshold level as of November 17, 2008. Threshold type: SMCL-US, U.S. Environmental Protection Agency secondary maximum contaminant level; SMCL-CA, California Department of Public Health secondary maximum contaminant level. Bicarbonate and carbonate concentrations were calculated from the field and laboratory alkalinity and $\mathrm{pH}$ values using the advanced speciation method (http://or.water.usgs.gov/alk/methods.html) with $\mathrm{pK}_{1}=6.35, \mathrm{pK}_{2}=10.33$, and $\mathrm{pK}_{\mathrm{w}}=14$. Abbreviations: C, Celsius; E, estimated or having a higher degree of uncertainty; $\mathrm{mg} / \mathrm{L}$, milligrams per liter; nc, not collected; na, not available; NTU, nephelometric turbidity unit; RL, reporting limit or range; $\mu \mathrm{S} / \mathrm{cm}$, microsiemens per centimeter; <, less than; >, greater than; $\mathrm{CaCO}_{3}$, calcium carbonate; *, value above threshold level; **, value above upper threshold level]

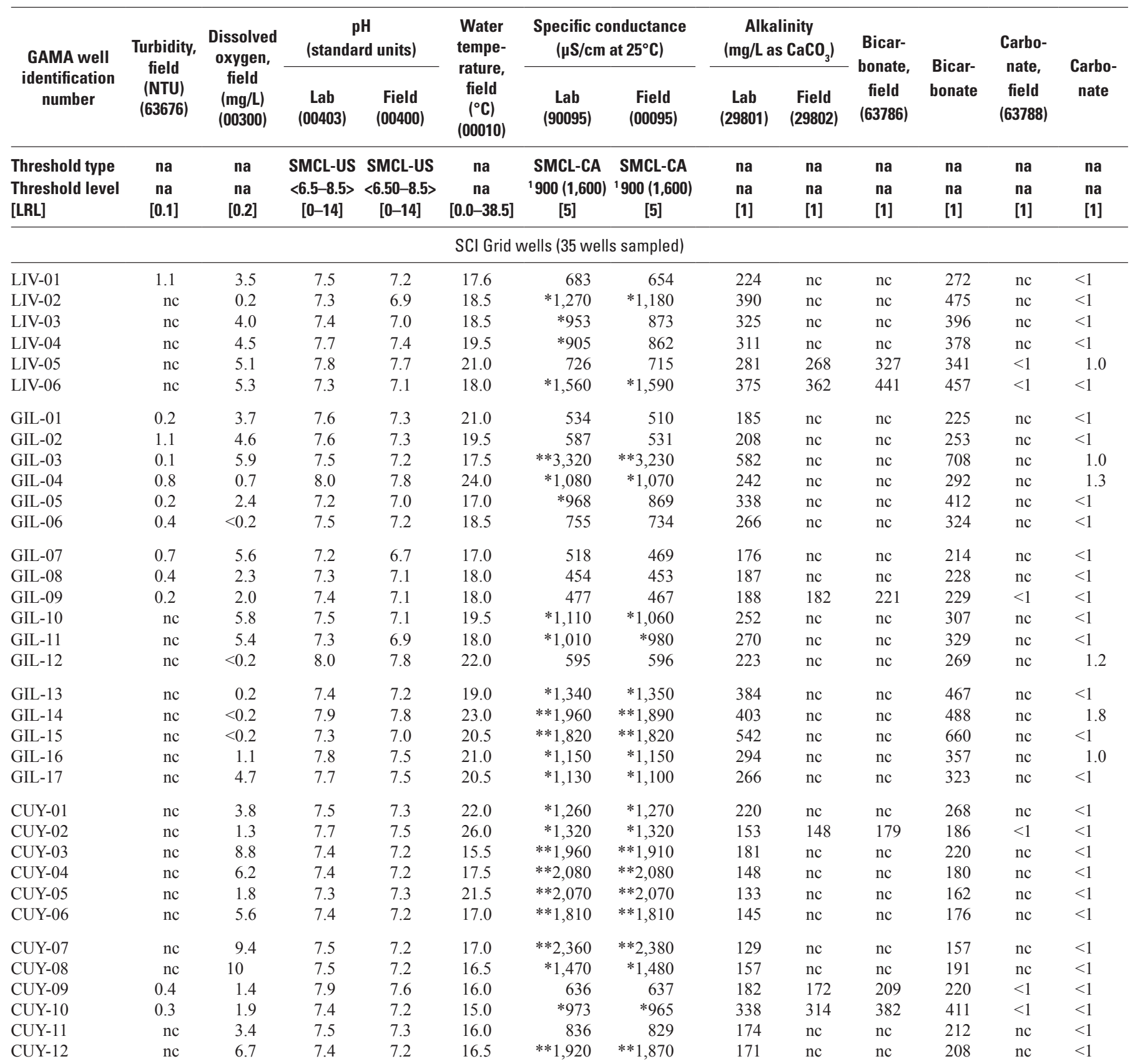


Table 4. Water-quality indicators (field parameters) in samples collected for the South Coast Interior Basins Groundwater Ambient Monitoring and Assessment (GAMA) study unit, California, August to December 2008.-Continued

[The five-digit U.S. Geological Survey (USGS) parameter code below the constituent name is used to uniquely identify a specific constituent or property. GAMA identification number: LIV, Livermore study area grid well; LIVU, Livermore study area understanding well; GIL, Gilroy study area grid well; GILU, Gilroy study area understanding well; CUY, Cuyama study area grid well; CUYU, Cuyama study area understanding well. Threshold type and threshold level as of November 17, 2008. Threshold type: SMCL-US, U.S. Environmental Protection Agency secondary maximum contaminant level; SMCL-CA, California Department of Public Health secondary maximum contaminant level. Bicarbonate and carbonate concentrations were calculated from the field and laboratory alkalinity and $\mathrm{pH}$ values using the advanced speciation method (http://or.water.usgs.gov/alk/methods.html) with $\mathrm{pK}_{1}=6.35, \mathrm{pK}_{2}=10.33$, and $\mathrm{pK}_{\mathrm{W}}=14$. Abbreviations: C, Celsius; E, estimated or having a higher degree of uncertainty; $\mathrm{mg} / \mathrm{L}$, milligrams per liter; nc, not collected; na, not available; NTU, nephelometric turbidity unit; RL, reporting limit or range; $\mu \mathrm{S} / \mathrm{cm}$, microsiemens per centimeter; <, less than; >, greater than; $\mathrm{CaCO}_{3}$, calcium carbonate; *, value above threshold level; **, value above upper threshold level]

\begin{tabular}{|c|c|c|c|c|c|c|c|c|c|c|c|c|c|}
\hline \multirow{2}{*}{$\begin{array}{c}\text { GAMA well } \\
\text { identification } \\
\text { number }\end{array}$} & \multirow{2}{*}{$\begin{array}{c}\text { Turbidity, } \\
\text { field } \\
\text { (NTU) } \\
\text { (63676) }\end{array}$} & \multirow{2}{*}{$\begin{array}{c}\text { Dissolved } \\
\text { oxygen, } \\
\text { field } \\
(\mathrm{mg} / \mathrm{L}) \\
(00300)\end{array}$} & \multicolumn{2}{|c|}{$\begin{array}{c}\mathrm{pH} \\
\text { (standard units) }\end{array}$} & \multirow{2}{*}{$\begin{array}{c}\text { Water } \\
\text { tempe- } \\
\text { rature, } \\
\text { field } \\
\left({ }^{\circ} \mathrm{C}\right) \\
(00010)\end{array}$} & \multicolumn{2}{|c|}{$\begin{array}{l}\text { Specific conductance } \\
\left(\mu \mathrm{S} / \mathrm{cm} \text { at } 25^{\circ} \mathrm{C}\right)\end{array}$} & \multicolumn{2}{|c|}{$\begin{array}{c}\text { Alkalinity } \\
\text { (mg/L as } \mathrm{CaCO}_{3} \text { ) }\end{array}$} & \multirow{2}{*}{$\begin{array}{c}\text { Bicar- } \\
\text { bonate, } \\
\text { field } \\
(63786)\end{array}$} & \multirow{2}{*}{$\begin{array}{l}\text { Bicar- } \\
\text { bonate }\end{array}$} & \multirow{2}{*}{$\begin{array}{l}\text { Carbo- } \\
\text { nate, } \\
\text { field } \\
\text { (63788) }\end{array}$} & \multirow{2}{*}{$\begin{array}{c}\text { Carbo- } \\
\text { nate }\end{array}$} \\
\hline & & & $\begin{array}{l}\text { Lab } \\
(00403)\end{array}$ & $\begin{array}{l}\text { Field } \\
(00400)\end{array}$ & & $\begin{array}{l}\text { Lab } \\
(90095)\end{array}$ & $\begin{array}{l}\text { Field } \\
\text { (00095) }\end{array}$ & $\begin{array}{c}\text { Lab } \\
(29801)\end{array}$ & $\begin{array}{l}\text { Field } \\
(29802)\end{array}$ & & & & \\
\hline Threshold type & na & na & SMCL-US & SMCL-US & na & SMCL-CA & SMCL-CA & na & na & na & na & na & na \\
\hline $\begin{array}{l}\text { Threshold level } \\
\text { [LRL] }\end{array}$ & $\begin{array}{c}\text { na } \\
{[0.1]}\end{array}$ & $\begin{array}{c}\text { na } \\
{[0.2]}\end{array}$ & $\begin{array}{c}<6.5-8.5> \\
{[0-14]}\end{array}$ & $\begin{array}{c}<6.50-8.5> \\
{[0-14]}\end{array}$ & $\begin{array}{c}\text { na } \\
{[0.0-38.5]}\end{array}$ & $\begin{array}{c}1900(1,600) \\
{[5]}\end{array}$ & $\begin{array}{c}1900(1,600) \\
{[5]}\end{array}$ & $\begin{array}{l}\text { na } \\
{[1]}\end{array}$ & $\begin{array}{l}\text { na } \\
{[1]}\end{array}$ & $\begin{array}{l}\text { na } \\
{[1]}\end{array}$ & $\begin{array}{l}\text { na } \\
{[1]}\end{array}$ & $\begin{array}{l}\text { na } \\
{[1]}\end{array}$ & $\begin{array}{l}\text { na } \\
{[1]}\end{array}$ \\
\hline \multicolumn{14}{|c|}{ SCI Understanding wells ( 19 wells sampled) } \\
\hline LIVU-01 & 0.8 & 5.0 & 7.7 & 7.2 & 17.5 & 793 & 755 & 286 & $\mathrm{nc}$ & $\mathrm{nc}$ & 347 & $\mathrm{nc}$ & $<1$ \\
\hline LIVU-02 & 6.9 & 3.8 & 7.6 & 7.2 & 17.5 & $* 1,180$ & $* 1,160$ & 355 & 340 & 414 & 431 & $<1$ & $<1$ \\
\hline LIVU-03 & 0.4 & 3.2 & 7.7 & 7.4 & 21.0 & $* 1,200$ & $* 1,180$ & 374 & 356 & 434 & 454 & $<1$ & 1.0 \\
\hline LIVU-04 & 3.2 & 5.1 & 7.5 & 7.2 & 23.0 & 677 & 647 & 214 & $\mathrm{nc}$ & $\mathrm{nc}$ & 260 & $\mathrm{nc}$ & $<1$ \\
\hline LIVU-05 & $\mathrm{nc}$ & 4.7 & 7.0 & 6.8 & 20.5 & $* * \mathrm{E} 34,800$ & $* * 40,300$ & 680 & $\mathrm{nc}$ & $\mathrm{nc}$ & 829 & $<1$ & $<1$ \\
\hline GILU-02 & 0.7 & 1.5 & 7.8 & 7.6 & 23.5 & 533 & 533 & 191 & 183 & 222 & 232 & $<1$ & $<1$ \\
\hline GILU-03 & $\mathrm{nc}$ & 3.4 & 7.5 & 7.3 & 19.0 & 524 & 526 & 193 & $\mathrm{nc}$ & $\mathrm{nc}$ & 235 & $\mathrm{nc}$ & $<1$ \\
\hline GILU-04 & $\mathrm{nc}$ & 4.1 & 7.5 & 7.4 & 20.0 & 502 & 505 & 181 & $\mathrm{nc}$ & $\mathrm{nc}$ & 220 & $\mathrm{nc}$ & $<1$ \\
\hline GILU-05 & $\mathrm{nc}$ & $<0.2$ & 8.0 & 7.9 & 22.0 & 539 & 546 & 204 & $\mathrm{nc}$ & $\mathrm{nc}$ & 247 & $\mathrm{nc}$ & 1.1 \\
\hline CUYU-01 & $\mathrm{nc}$ & 4.5 & 7.6 & 7.3 & 14.5 & $* 1,160$ & $* 1,150$ & 352 & $\mathrm{nc}$ & $\mathrm{nc}$ & 428 & $\mathrm{nc}$ & $<1$ \\
\hline CUYU-02 & 0.3 & 6.4 & 7.3 & 7.1 & 11.0 & *964 & *953 & 413 & $\mathrm{nc}$ & $\mathrm{nc}$ & 503 & $\mathrm{nc}$ & $<1$ \\
\hline CUYU-03 & $\mathrm{nc}$ & 5.2 & 7.5 & 7.2 & 12.5 & $* 1,340$ & $* 1,290$ & 382 & $\mathrm{nc}$ & $\mathrm{nc}$ & 465 & $\mathrm{nc}$ & $<1$ \\
\hline CUYU-04 & $\mathrm{nc}$ & 2.5 & 7.5 & 7.2 & 13.0 & 575 & 567 & 291 & $\mathrm{nc}$ & $\mathrm{nc}$ & 354 & $\mathrm{nc}$ & $<1$ \\
\hline CUYU-05 & $\mathrm{nc}$ & 6.3 & 7.7 & 7.4 & 15.5 & 903 & 890 & 283 & $\mathrm{nc}$ & $\mathrm{nc}$ & 344 & $\mathrm{nc}$ & $<1$ \\
\hline CUYU-06 & 2.0 & 6.3 & 7.6 & 7.4 & 17.0 & 911 & 891 & 297 & 287 & 348 & 361 & $<1$ & $<1$ \\
\hline
\end{tabular}

\footnotetext{
${ }^{1}$ The SMCL-CA for specific conductance has recommended and upper threshold values. The upper value is shown in parentheses.
} 
Table 5. Volatile organic compounds (VOCs) detected in samples collected for the South Coast Interior Basins Groundwater Ambient Monitoring and Assessment (GAMA) study, California, August to December 2008.

[The five-digit U.S. Geological Survey (USGS) parameter code below the constituent name is used to uniquely identify a specific constituent or property. Samples from all 54 wells were analyzed, but only samples with detections are listed. Analytes are listed in order of decreasing detection frequency in the 35 grid wells. All analytes are listed in table 3A. GAMA well identification number: LIV, Livermore study area grid well; LIVU, Livermore study area understanding well; GIL, Gilroy study area grid well; GILU, Gilroy study area understanding well; CUY, Cuyama study area grid well; CUYU, Cuyama study area understanding well. Threshold type and threshold level as of November 17, 2008. Threshold type: Maximum contaminant level thresholds are listed as MCL-US when the MCL-US and MCL-CA are identical, and as MCL-CA when the MCL-CA is lower than the MCL-US or no MCL-US exists. HAL-US, U.S. Environmental Protection Agency lifetime health advisory level; MCL-US, U.S. Environmental Protection Agency maximum contaminant level; MCL-CA; California Department of Public Health maximum contaminant level; NL-CA, California Department of Public Health notification level. Abbreviations: E, estimated or having a higher degree of uncertainty; LRL, laboratory reporting level; $\mathrm{V}$, analyte detected in sample and an associated blank, thus data are not included in groundwater quality assessment; $\mu \mathrm{g} / \mathrm{L}$, microgram per liter; na, not available; -, not detected]

\begin{tabular}{|c|c|c|c|c|c|c|c|}
\hline \multirow[b]{2}{*}{$\begin{array}{c}\text { GAMA well } \\
\text { identification } \\
\text { number }\end{array}$} & \multirow{2}{*}{$\begin{array}{c}\text { Trihalo- } \\
\text { methane }\end{array}$} & \multirow{2}{*}{$\begin{array}{c}\text { Refrigerant } \\
\text { Dichloro- } \\
\text { difluoro- } \\
\text { methane } \\
\text { (CFC-12) } \\
(\mu \mathrm{g} / \mathrm{L}) \\
(34668)\end{array}$} & \multirow{2}{*}{$\begin{array}{c}\text { Solvent } \\
\text { Perchloro- } \\
\text { ethene } \\
\text { (PCE, Tetra- } \\
\text { chloroethene) } \\
(\mu \mathrm{g} / \mathrm{L}) \\
(34475)\end{array}$} & \multirow{2}{*}{$\begin{array}{c}\begin{array}{c}\text { Organic } \\
\text { synthesis }\end{array} \\
\begin{array}{c}\text { 1,1-Dichloro- } \\
\text { ethene } \\
\text { (1,1-DCE) } \\
(\mu \mathrm{g} / \mathrm{L}) \\
(34501)\end{array}\end{array}$} & \multicolumn{3}{|c|}{ Solvent } \\
\hline & & & & & $\begin{array}{c}\text { Carbon } \\
\text { disulfide } \\
(\mu \mathrm{g} / \mathrm{L}) \\
(77041)\end{array}$ & $\begin{array}{c}\text { Carbon tetra } \\
\text { chloride } \\
\text { (Tetrachloro- } \\
\text { methane) } \\
(\mu \mathrm{g} / \mathrm{L}) \\
(32102)\end{array}$ & $\begin{array}{c}\text { Tetrahy- } \\
\text { drofuran } \\
(\mu \mathrm{g} / \mathrm{L}) \\
(81607)\end{array}$ \\
\hline Threshold level & 180 & 1,000 & 5 & 6 & 4,000 & 0.5 & na \\
\hline [LRL] & {$[0.04]$} & {$[0.1]$} & {$[0.04]$} & {$[0.02]$} & {$[1.6]$} & {$[0.06]$} & [1.4] \\
\hline \multicolumn{8}{|c|}{ SCI Grid wells (35 wells sampled) } \\
\hline $\begin{array}{l}\text { Number of wells with } \\
\text { detections }\end{array}$ & 4 & 2 & 1 & 1 & 1 & 1 & 1 \\
\hline
\end{tabular}

\begin{tabular}{|c|c|c|c|c|c|c|c|}
\hline \multicolumn{8}{|c|}{ SCI Livermore study area (6 grid wells sampled) } \\
\hline LIV-02 & - & - & - & - & E1.5 & - & 2 \\
\hline LIV-03 & 0.15 & - & - & - & - & - & - \\
\hline LIV-04 & 0.10 & E0.17 & - & - & - & E0.05 & - \\
\hline $\begin{array}{l}\text { Number of wells with } \\
\text { detections }\end{array}$ & 3 & 1 & 1 & 1 & 1 & 1 & 1 \\
\hline $\begin{array}{l}\text { Detection frequency } \\
\text { (percent) }\end{array}$ & 50.0 & 16.7 & 16.7 & 16.7 & 16.7 & 16.7 & 16.7 \\
\hline
\end{tabular}

\begin{tabular}{|c|c|c|c|c|c|c|c|}
\hline \multicolumn{8}{|c|}{ SCI Gilroy study area (17 grid wells sampled) } \\
\hline GIL-05 & - & - & - & - & - & - & - \\
\hline GIL-09 & - & - & - & - & - & - & - \\
\hline $\begin{array}{l}\text { Number of wells with } \\
\text { detections }\end{array}$ & 0 & 1 & 0 & 0 & 0 & 0 & 0 \\
\hline $\begin{array}{l}\text { Detection frequency } \\
\text { (percent) } \\
\text { Total Detections }\end{array}$ & 0 & 5.8 & 0 & 0 & 0 & 0 & 0 \\
\hline
\end{tabular}

\begin{tabular}{|c|c|c|c|c|c|c|c|}
\hline CUY-10 & E0.06 & - & - & - & - & - & - \\
\hline Detection frequency & 8.3 & 0 & 0 & 0 & 0 & 0 & 0 \\
\hline
\end{tabular}

(percent)

Total Detections 
Table 5. Volatile organic compounds (VOCs) detected in samples collected for the South Coast Interior Basins Groundwater Ambient Monitoring and Assessment (GAMA) study, California, August to December 2008.—Continued

[The five-digit U.S. Geological Survey (USGS) parameter code below the constituent name is used to uniquely identify a specific constituent or property. Samples from all 54 wells were analyzed, but only samples with detections are listed. Analytes are listed in order of decreasing detection frequency in the 35 grid wells. All analytes are listed in table $3 A$. GAMA well identification number: LIV, Livermore study area grid well; LIVU, Livermore study area understanding well; GIL, Gilroy study area grid well; GILU, Gilroy study area understanding well; CUY, Cuyama study area grid well; CUYU, Cuyama study area understanding well. Threshold type and threshold level as of November 17, 2008. Threshold type: Maximum contaminant level thresholds are listed as MCL-US when the MCL-US and MCL-CA are identical, and as MCL-CA when the MCL-CA is lower than the MCL-US or no MCL-US exists. HAL-US, U.S. Environmental Protection Agency lifetime health advisory level; MCL-US, U.S. Environmental Protection Agency maximum contaminant level; MCL-CA; California Department of Public Health maximum contaminant level; NL-CA, California Department of Public Health notification level. Abbreviations: E, estimated or having a higher degree of uncertainty; LRL, laboratory reporting level; $\mathrm{V}$, analyte detected in sample and an associated blank, thus data are not included in groundwater quality assessment; $\mu \mathrm{g} / \mathrm{L}$, microgram per liter; na, not available; - , not detected]

\begin{tabular}{|c|c|c|c|c|c|c|c|}
\hline \multirow[b]{2}{*}{$\begin{array}{c}\text { GAMA well } \\
\text { identification } \\
\text { number }\end{array}$} & \multirow{2}{*}{$\begin{array}{c}\begin{array}{c}\text { Trihalo- } \\
\text { methane }\end{array} \\
\text { Chloroform } \\
\text { (Trichloro- } \\
\text { methane) } \\
(\mu \mathrm{g} / \mathrm{L}) \\
(32106)\end{array}$} & \multirow{2}{*}{$\begin{array}{c}\text { Refrigerant } \\
\text { Dichloro- } \\
\text { difluoro- } \\
\text { methane } \\
\text { (CFC-12) } \\
(\mu \mathrm{g} / \mathrm{L}) \\
(34668) \\
\end{array}$} & \multirow{2}{*}{$\begin{array}{c}\text { Solvent } \\
\text { Perchloro- } \\
\text { ethene } \\
\text { (PCE, Tetra- } \\
\text { chloroethene) } \\
(\mu \mathrm{g} / \mathrm{L}) \\
(34475) \\
\end{array}$} & \multirow{2}{*}{$\begin{array}{c}\begin{array}{c}\text { Organic } \\
\text { synthesis }\end{array} \\
\begin{array}{c}\text { 1,1-Dichloro- } \\
\text { ethene } \\
(1,1-D C E) \\
(\mu \mathrm{g} / \mathrm{L}) \\
(34501)\end{array}\end{array}$} & \multicolumn{3}{|c|}{ Solvent } \\
\hline & & & & & $\begin{array}{c}\text { Carbon } \\
\text { disulfide } \\
(\mu \mathrm{g} / \mathrm{L}) \\
(77041)\end{array}$ & $\begin{array}{c}\text { Carbon tetra } \\
\text { chloride } \\
\text { (Tetrachloro- } \\
\text { methane) } \\
(\mu \mathrm{g} / \mathrm{L}) \\
(32102)\end{array}$ & $\begin{array}{c}\text { Tetrahy- } \\
\text { drofuran } \\
(\mu \mathrm{g} / \mathrm{L}) \\
(81607)\end{array}$ \\
\hline $\begin{array}{l}\text { Threshold level } \\
\text { [LRL] }\end{array}$ & $\begin{array}{c}180 \\
{[0.04]}\end{array}$ & $\begin{array}{l}1,000 \\
{[0.1]}\end{array}$ & $\begin{array}{c}5 \\
{[0.04]}\end{array}$ & $\begin{array}{c}6 \\
{[0.02]}\end{array}$ & $\begin{array}{r}4,000 \\
{[1.6]}\end{array}$ & $\begin{array}{c}0.5 \\
{[0.06]}\end{array}$ & $\begin{array}{c}\text { na } \\
{[1.4]}\end{array}$ \\
\hline \multicolumn{8}{|c|}{ SCI Understanding wells ${ }^{2}$ (19 wells sampled) } \\
\hline LIVU-01 & V0.04 & - & - & - & - & - & - \\
\hline LIVU-02 & E0.09 & - & - & - & - & - & - \\
\hline LIVU-03 & 0.14 & - & - & - & - & - & - \\
\hline CUYU-04 & - & - & E0.06 & - & - & - & - \\
\hline CUYU-05 & V0.01 & - & E0.04 & - & - & - & - \\
\hline CUYU-06 & - & - & E0.02 & - & - & - & - \\
\hline
\end{tabular}


Table 5. Volatile organic compounds (VOCs) detected in samples collected for the South Coast Interior Basins Groundwater Ambient Monitoring and Assessment (GAMA) study, California, August to December 2008. - Continued

[The five-digit U.S. Geological Survey (USGS) parameter code below the constituent name is used to uniquely identify a specific constituent or property. Samples from all 54 wells were analyzed, but only samples with detections are listed. Analytes are listed in order of decreasing detection frequency in the 35 grid wells. All analytes are listed in table 3A. GAMA well identification number: LIV, Livermore study area grid well; LIVU, Livermore study area understanding well; GIL, Gilroy study area grid well; GILU, Gilroy study area understanding well; CUY, Cuyama study area grid well; CUYU, Cuyama study area understanding well. Threshold type and threshold level as of November 17, 2008. Threshold type: Maximum contaminant level thresholds are listed as MCL-US when the MCL-US and MCL-CA are identical, and as MCL-CA when the MCL-CA is lower than the MCL-US or no MCL-US exists. HAL-US, U.S. Environmental Protection Agency lifetime health advisory level; MCL-US, U.S. Environmental Protection Agency maximum contaminant level; MCL-CA; California Department of Public Health maximum contaminant level; NL-CA, California Department of Public Health notification level. Abbreviations: E, estimated or having a higher degree of uncertainty; LRL, laboratory reporting level; $\mathrm{V}$, analyte detected in sample and an associated blank, thus data are not included in groundwater quality assessment; $\mu \mathrm{g} / \mathrm{L}$, microgram per liter; na, not available; -, not detected]

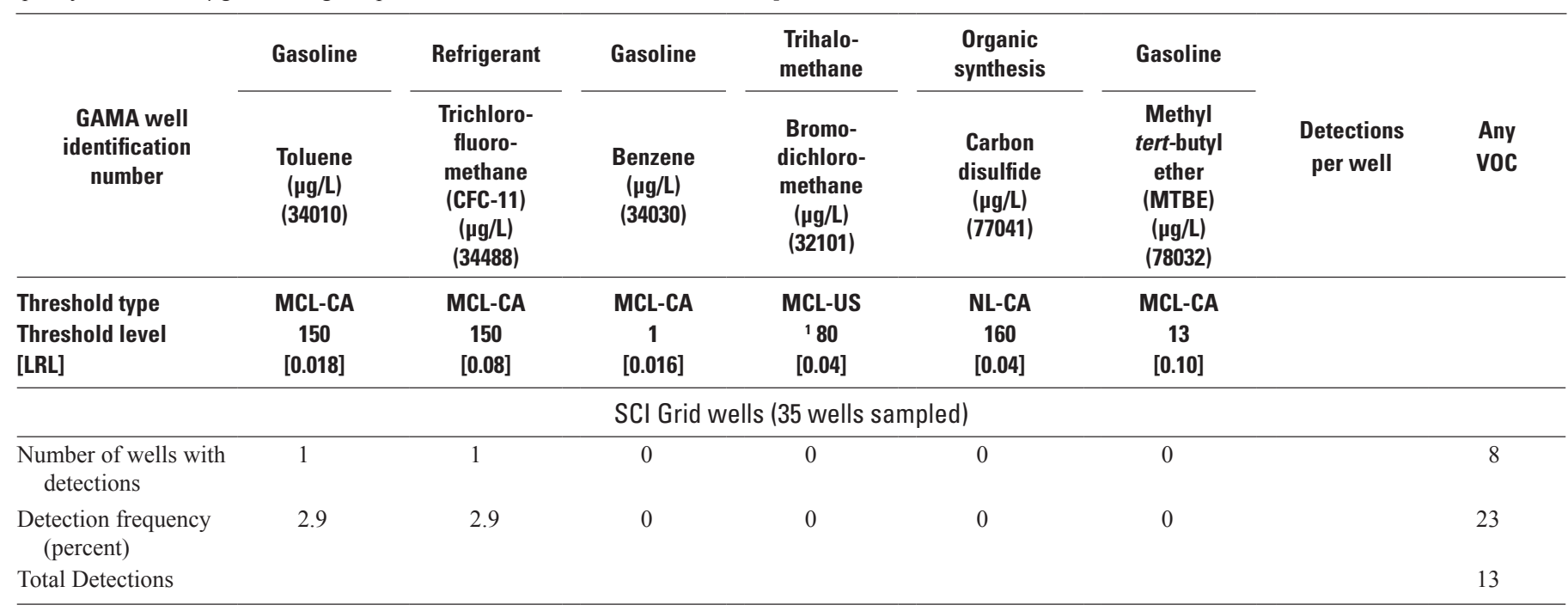

\begin{tabular}{|c|c|c|c|c|c|c|c|c|}
\hline \multicolumn{9}{|c|}{ SCI Livermore study area (6 grid wells sampled) } \\
\hline LIV-02 & - & - & - & - & - & - & 2 & \\
\hline LIV-03 & - & - & - & - & - & - & 1 & \\
\hline LIV-04 & - & - & - & - & - & - & 3 & \\
\hline $\begin{array}{l}\text { Number of wells with } \\
\text { detections }\end{array}$ & 0 & 0 & 0 & 0 & 0 & 0 & & 4 \\
\hline $\begin{array}{l}\text { Detection frequency } \\
\text { (percent) }\end{array}$ & 0 & 0 & 0 & 0 & 0 & 0 & & 67 \\
\hline
\end{tabular}

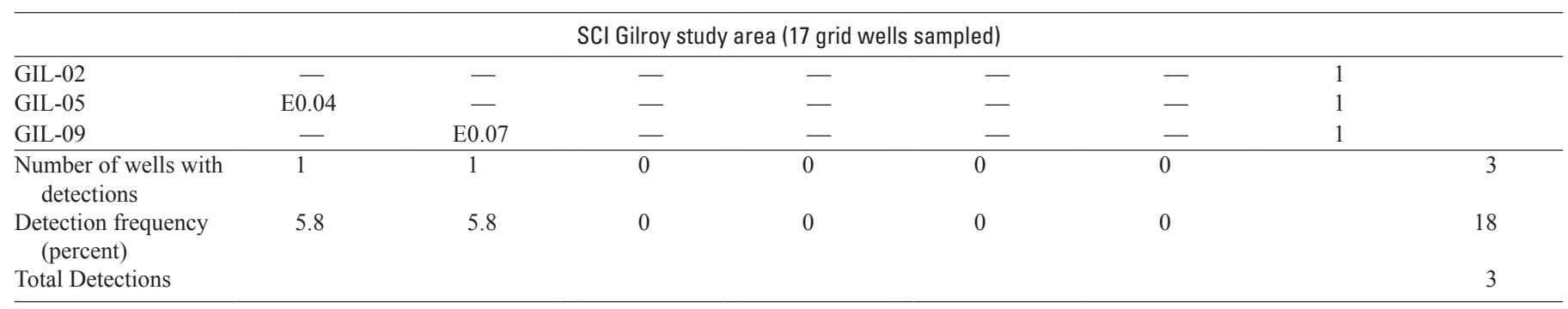

\begin{tabular}{|c|c|c|c|c|c|c|c|c|}
\hline \multicolumn{9}{|c|}{ SCI Cuyama study area (12 grid wells sampled) } \\
\hline CUY-10 & - & - & - & - & - & - & 1 & \\
\hline $\begin{array}{l}\text { Number of wells with } \\
\text { detections }\end{array}$ & 0 & 0 & 0 & 0 & 0 & 0 & & 1 \\
\hline $\begin{array}{l}\text { Detection frequency } \\
\text { (percent) }\end{array}$ & 0 & 0 & 0 & 0 & 0 & 0 & & 8 \\
\hline Total Detections & & & & & & & & 1 \\
\hline
\end{tabular}


Table 5. Volatile organic compounds (VOCs) detected in samples collected for the South Coast Interior Basins Groundwater Ambient Monitoring and Assessment (GAMA) study, California, August to December 2008. - Continued

[The five-digit U.S. Geological Survey (USGS) parameter code below the constituent name is used to uniquely identify a specific constituent or property. Samples from all 54 wells were analyzed, but only samples with detections are listed. Analytes are listed in order of decreasing detection frequency in the 35 grid wells. All analytes are listed in table 3A. GAMA well identification number: LIV, Livermore study area grid well; LIVU, Livermore study area understanding well; GIL, Gilroy study area grid well; GILU, Gilroy study area understanding well; CUY, Cuyama study area grid well; CUYU, Cuyama study area understanding well. Threshold type and threshold level as of November 17, 2008. Threshold type: Maximum contaminant level thresholds are listed as MCL-US when the MCL-US and MCL-CA are identical, and as MCL-CA when the MCL-CA is lower than the MCL-US or no MCL-US exists. HAL-US, U.S. Environmental Protection Agency lifetime health advisory level; MCL-US, U.S. Environmental Protection Agency maximum contaminant level; MCL-CA; California Department of Public Health maximum contaminant level; NL-CA, California Department of Public Health notification level. Abbreviations: E, estimated or having a higher degree of uncertainty; LRL, laboratory reporting level; V, analyte detected in sample and an associated blank, thus data are not included in groundwater quality assessment; $\mu \mathrm{g} / \mathrm{L}$, microgram per liter; na, not available; -, not detected]

\begin{tabular}{|c|c|c|c|c|c|c|c|c|}
\hline & Gasoline & Refrigerant & Gasoline & $\begin{array}{l}\text { Trihalo- } \\
\text { methane }\end{array}$ & $\begin{array}{l}\text { Organic } \\
\text { synthesis }\end{array}$ & Gasoline & & \\
\hline $\begin{array}{c}\text { GAMA well } \\
\text { identification } \\
\text { number }\end{array}$ & $\begin{array}{c}\text { Toluene } \\
\text { ( } \mu \mathrm{gg} / \mathrm{L}) \\
(\mathbf{3 4 0 1 0})\end{array}$ & $\begin{array}{c}\text { Trichloro- } \\
\text { fluoro- } \\
\text { methane } \\
\text { (CFC-11) } \\
(\mu \mathrm{g} / \mathrm{L}) \\
(34488)\end{array}$ & $\begin{array}{c}\text { Benzene } \\
(\mu \mathrm{g} / \mathrm{L}) \\
(\mathbf{3 4 0 3 0})\end{array}$ & $\begin{array}{c}\text { Bromo- } \\
\text { dichloro- } \\
\text { methane } \\
\text { ( } \mathrm{gg} / \mathrm{L}) \\
(32101)\end{array}$ & $\begin{array}{c}\text { Carbon } \\
\text { disulfide } \\
(\mu \mathrm{g} / \mathrm{L}) \\
(77041)\end{array}$ & $\begin{array}{c}\text { Methyl } \\
\text { tert-butyl } \\
\text { ether } \\
\text { (MTBE) } \\
(\mu \mathrm{g} / \mathrm{L}) \\
(78032)\end{array}$ & $\begin{array}{c}\text { Detections } \\
\text { per well }\end{array}$ & $\begin{array}{l}\text { Any } \\
\text { VOC }\end{array}$ \\
\hline $\begin{array}{l}\text { Threshold level } \\
\text { [LRL] }\end{array}$ & $\begin{array}{c}150 \\
{[0.018]}\end{array}$ & $\begin{array}{c}150 \\
{[0.08]}\end{array}$ & $\begin{array}{c}1 \\
{[0.016]}\end{array}$ & $\begin{array}{c}180 \\
{[0.04]}\end{array}$ & $\begin{array}{c}160 \\
{[0.04]}\end{array}$ & $\begin{array}{c}13 \\
{[0.10]}\end{array}$ & & \\
\hline \multicolumn{9}{|c|}{ SCI Understanding wells ${ }^{2} 19$ wells sampled) } \\
\hline LIVU-01 & - & - & - & - & - & - & 0 & \\
\hline LIVU-02 & - & - & - & E0.07 & - & - & 2 & \\
\hline LIVU-03 & - & - & - & - & - & - & 1 & \\
\hline CUYU-04 & - & - & - & - & - & - & 1 & \\
\hline CUYU-05 & - & - & - & - & - & - & 1 & \\
\hline CUYU-06 & - & - & - & - & - & 0.4 & 2 & \\
\hline
\end{tabular}

${ }^{1}$ The MCL-US threshold for trihalomethanes is for the sum of chloroform, bromoform, bromodichloromethane, and dibromochloromethane.

${ }^{2}$ Understanding wells were not included in statistical calculations. 
Table 6A. Pesticides and pesticide degradates detected in samples collected for the South Coast Interior Basins Groundwater Ambient Monitoring and Assessment (GAMA) study unit, California, August to December 2008.

[The five-digit U.S. Geological Survey (USGS) parameter code below the constituent name is used to uniquely identify a specific constituent or property. Samples from all 54 wells were analyzed, but only samples with detections are listed. Analytes are listed in order of decreasing detection frequency in the 35 grid wells. All analytes are listed in table 3B. GAMA well identification number: LIV, Livermore study area grid well; LIVU, Livermore study area understanding well; GIL, Gilroy study area grid well; GILU, Gilroy study area understanding well; CUYU, Cuyama study area understanding well. Threshold type and threshold level as of November 17, 2008. Threshold type: Maximum contaminant level thresholds are listed as MCL-US when the MCL-US and MCL-CA are identical, and as MCL-CA when the MCL-CA is lower than the MCL-US or no MCL-US exists. HAL-US, U.S. Environmental Protection Agency lifetime health advisory level; MCL-US, U.S. Environmental Protection Agency maximum contaminant level; MCL-CA; California Department of Public Health maximum contaminant level. Abbreviations: E, estimated or having a higher degree of uncertainty; LRL, laboratory reporting level; V, analyte detected in sample and an associated blank, thus data are not included in groundwater quality assessment; $\mu \mathrm{g} / \mathrm{L}$, microgram per liter; na, not available; -, not detected]

\begin{tabular}{|c|c|c|c|c|c|c|c|}
\hline $\begin{array}{c}\text { GAMA well } \\
\text { identification } \\
\text { number }\end{array}$ & $\begin{array}{c}\text { Simazine } \\
(\mu \mathrm{g} / \mathrm{L}) \\
(04035)\end{array}$ & $\begin{array}{c}\text { Deethy- } \\
\text { latrazine } \\
\text { (2-Chloro-4- } \\
\text { isopropylamino- } \\
6 \text {-amino- } s- \\
\text { triazine) } \\
(\mu \mathrm{g} / \mathrm{L}) \\
(04040)\end{array}$ & $\begin{array}{c}\text { Prometon } \\
(\mu \mathrm{g} / \mathrm{L}) \\
(04037)\end{array}$ & $\begin{array}{c}\text { Tebuthiuron } \\
(\mu \mathrm{g} / \mathrm{L}) \\
(82670)\end{array}$ & $\begin{array}{c}\text { Atrazine } \\
(\mu \mathrm{g} / \mathrm{L}) \\
(39632)\end{array}$ & $\begin{array}{c}\text { Pesticide } \\
\text { detections } \\
\text { per well }\end{array}$ & $\begin{array}{c}\text { Any } \\
\text { pesticide }\end{array}$ \\
\hline Threshold type & MCL-US & na & HAL-US & HAL-US & MCL-CA & & \\
\hline Threshold level & 4 & na & 100 & 500 & 1 & & \\
\hline [LRL] & {$[0.01]$} & {$[0.014]$} & {$[0.012]$} & {$[0.02]$} & {$[0.007]$} & & \\
\hline \multicolumn{8}{|c|}{ SCI grid wells ( 35 grid wells sampled) } \\
\hline $\begin{array}{l}\text { Number of wells with } \\
\text { detections }\end{array}$ & 7 & 2 & 2 & 1 & 0 & & 8 \\
\hline $\begin{array}{l}\text { Detection frequency } \\
\text { (percent) }\end{array}$ & 20.0 & 5.7 & 5.7 & 2.9 & 0 & & 23 \\
\hline Total Detections & & & & & & & 12 \\
\hline \multicolumn{8}{|c|}{ SCI Livermore study area (6 grid wells sampled) } \\
\hline LIV-02 & E0.005 & $-\overline{-}$ & E0.005 & E0.03 & V0.007 & 3 & \\
\hline LIV-03 & E0.006 & E0.005 & - & - & V0.006 & 2 & \\
\hline LIV-06 & E0.009 & - & 0.021 & - & - & 2 & \\
\hline $\begin{array}{l}\text { Number of wells with } \\
\text { detections }\end{array}$ & 3 & 1 & 2 & 1 & 0 & & 3 \\
\hline $\begin{array}{l}\text { Detection frequency } \\
\text { (percent) }\end{array}$ & 50.0 & 16.7 & 33.3 & 16.7 & 0 & & 50 \\
\hline Total Detections & & & & & & & 7 \\
\hline \multicolumn{8}{|c|}{ SCI Gilroy study area (17 grid wells sampled) } \\
\hline GIL-03 & - & E0.008 & - & - & - & 1 & \\
\hline GIL-05 & E0.006 & - & - & - & - & 1 & \\
\hline GIL-07 & E0.005 & - & - & - & - & 1 & \\
\hline GIL-08 & E0.005 & - & - & - & - & 1 & \\
\hline GIL-13 & E0.006 & - & - & - & - & 1 & \\
\hline $\begin{array}{l}\text { Number of wells with } \\
\text { detections }\end{array}$ & 4 & 1 & 0 & 0 & 0 & & 5 \\
\hline $\begin{array}{l}\text { Detection frequency } \\
\text { (percent) }\end{array}$ & 23.5 & 5.9 & 0 & 0 & 0 & & 29 \\
\hline Total Detections & & & & & & & 5 \\
\hline \multicolumn{8}{|c|}{ SCI Understanding wells ${ }^{1}$ (19 wells sampled) } \\
\hline LIVU-04 & E0.006 & - & - & - & - & 1 & \\
\hline CUYU-05 & E0.005 & E0.006 & - & - & - & 2 & \\
\hline CUYU-06 & 0.014 & E0.011 & - & - & V0.008 & 2 & \\
\hline
\end{tabular}

\footnotetext{
${ }^{1}$ Understanding wells were not included in statistical calculations.
} 
Table 6B. Polar pesticides and metabolites detected in samples collected for the South Coast Interior Basins Groundwater Ambient Monitoring and Assessment (GAMA) study, California, August to December 2008.

[The five-digit U.S. Geological Survey (USGS) parameter code below the constituent name is used to uniquely identify a specific constituent or property. Samples from the 11 slow wells were analyzed, but only the sample with a detection is listed. All analytes are listed in table $3 C$. GAMA well identification number: LIV, Livermore study area grid well. Threshold type and threshold level as of November 17, 2008. Threshold type: Maximum contaminant level thresholds are listed as MCL-US when the MCL-US and MCL-CA are identical, and as MCL-CA when the MCL-CA is lower than the MCL-US or no MCL-US exists. MCL-CA; California Department of Public Health maximum contaminant level. Abbreviations: LRL, laboratory reporting level; $\mu \mathrm{g} / \mathrm{L}$, microgram per liter]

\begin{tabular}{lcc}
\hline \multicolumn{1}{c}{$\begin{array}{c}\text { GAMA well } \\
\text { identification } \\
\text { number }\end{array}$} & $\begin{array}{c}\text { Bentazon } \\
(\boldsymbol{\mu g} / \mathbf{L}) \\
(\mathbf{3 8 7 1 1})\end{array}$ \\
\hline $\begin{array}{l}\text { Threshold type } \\
\text { Threshold level }\end{array}$ & MCL-CA \\
[LRL] & $\mathbf{1 8}$ \\
\hline & {$[\mathbf{0 . 0 6}]$} \\
\hline & SCl slow wells (11 wells sampled) \\
\hline
\end{tabular}


Table 7. Constituents of special interest (perchlorate and $N$-nitrosodimethylamine [NDMA]) collected for the South Coast Interior Basins Groundwater Ambient Monitoring and Assessment (GAMA) study, California, August to December 2008.

[The five-digit USGS parameter code below the constituent name is used to uniquely identify a specific constituent or property. Samples from all 54 wells were analyzed for perchlorate; samples from the 11 slow wells were sampled for NDMA; detection frequency presented for perchlorate only. Information about the analytes given in table 3E. GAMA well identification number: LIV, Livermore study area grid well; LIVU, Livermore study area understanding well; GIL, Gilroy study area grid well; GILU, Gilroy study area understanding well; CUY, Cuyama study area grid well; CUYU, Cuyama study area understanding well. Threshold type and threshold level as of November 17, 2008. Threshold type: Maximum contaminant level thresholds are listed as MCL-US when the MCL-US and MCL-CA are identical, and as MCL-CA when the MCL-CA is lower than the MCL-US or no MCL-US exists. MCL-CA, California Department of Public Health maximum contaminant level; NL-CA, California Department of Public Health notification level. Summary statistics were not calculated for NDMA because it was not sampled at all grid wells. Abbreviations: MRL, method reporting level; $\mu \mathrm{g} / \mathrm{L}$, microgram per liter; nc, not collected; -, not detected; *, value above threshold level]

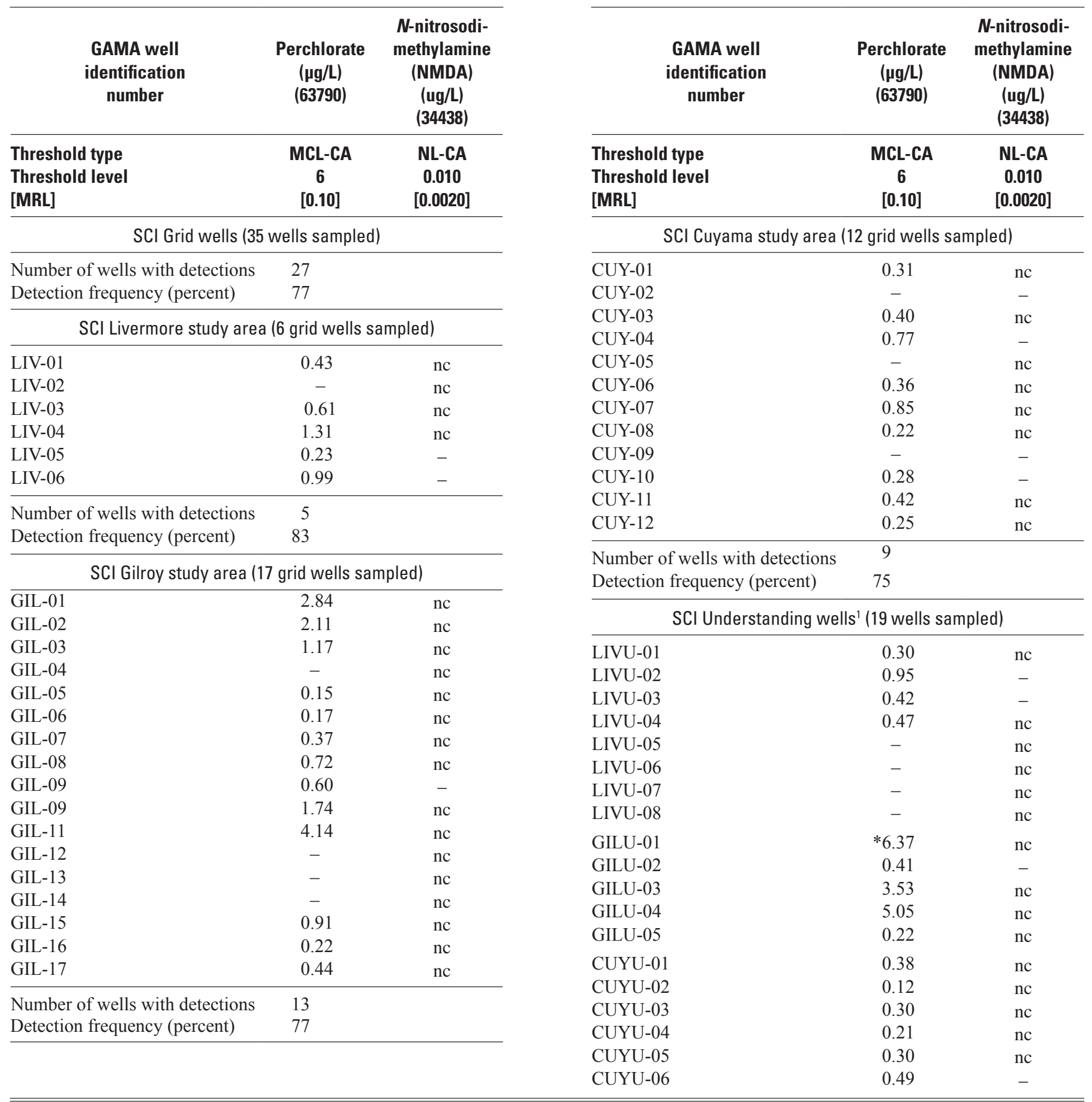

\footnotetext{
${ }^{1}$ Understanding wells were not included in statistical calculations.
} 
Table 8. Trace elements collected for the South Coast Interior Basins Groundwater Ambient Monitoring and Assessment (GAMA) study, California, August to December 2008.

[The five-digit U.S. Geological Survey (USGS) parameter code below the constituent name is used to uniquely identify a specific constituent or property. Samples from all 54 wells were analyzed. Information about the analytes given in table $3 F$. GAMA well identification number: LIV, Livermore study area grid well; LIVU, Livermore study area understanding well; GIL, Gilroy study area grid well; GILU, Gilroy study area understanding well; CUY, Cuyama study area grid well; CUYU, Cuyama study area understanding well. Threshold type and threshold level as of November 17, 2008. Threshold type: Maximum contaminant level thresholds are listed as MCL-US when the MCL-US and MCL-CA are identical, and as MCL-CA when the MCL-CA is lower than the MCL-US or no MCL-US exists. AL-US, U.S. Environmental Protection Agency action level; HAL-US, U.S. Environmental Protection Agency lifetime health advisory level; MCL-CA, California Department of Public Health maximum contaminant level; MCL-US, U.S. Environmental Protection Agency maximum contaminant level; NL-CA, California Department of Public Health notification level; SMCL-CA, California Department of Public Health secondary maximum contaminant level. Abbreviations: E, estimated or having a higher degree of uncertainty; LRL, laboratory reporting level; SRL, study reporting limit; $\mu \mathrm{g} / \mathrm{L}$, microgram per liter; na, not available; - , not detected; $\leq$ less than or equal to; *, value above threshold level]

\begin{tabular}{|c|c|c|c|c|c|c|c|c|c|c|c|c|}
\hline $\begin{array}{l}\text { GAMA well } \\
\text { identification } \\
\text { number }\end{array}$ & $\begin{array}{c}\text { Aluminum } \\
(\mu \mathrm{g} / \mathrm{L}) \\
(01106)\end{array}$ & $\begin{array}{c}\text { Antimony } \\
(\mu \mathrm{g} / \mathrm{L}) \\
(01095)\end{array}$ & $\begin{array}{c}\text { Arsenic } \\
(\mu \mathrm{g} / \mathrm{L}) \\
(01000)\end{array}$ & $\begin{array}{l}\text { Barium } \\
(\mu \mathrm{g} / \mathrm{L}) \\
(\mathbf{0 1 0 0 5})\end{array}$ & $\begin{array}{c}\text { Beryllium } \\
(\mu \mathrm{g} / \mathrm{L}) \\
(01010)\end{array}$ & $\begin{array}{c}\text { Boron } \\
(\mu \mathrm{g} / \mathrm{L}) \\
(01020)\end{array}$ & $\begin{array}{c}\text { Cadmium } \\
(\mu \mathrm{g} / \mathrm{L}) \\
(01025)\end{array}$ & $\begin{array}{c}\text { Chromium } \\
(\mu \mathrm{g} / \mathrm{L}) \\
(01030)\end{array}$ & $\begin{array}{c}\text { Cobalt } \\
\text { ( } \mu \mathrm{gg} / \mathrm{L}) \\
(01035)\end{array}$ & $\begin{array}{c}\text { Copper } \\
(\mu \mathrm{g} / \mathrm{L}) \\
(01040)\end{array}$ & $\begin{array}{c}\text { Iron } \\
(\mu \mathrm{g} / \mathrm{L}) \\
(01046)\end{array}$ & $\begin{array}{c}\text { Lead, } \\
\text { ( } \mu \mathrm{g} / \mathrm{L}) \\
(01049)\end{array}$ \\
\hline Threshold type & MCL-CA & MCL-US & MCL-US & MCL-CA & MCL-US & NL-CA & MCL-US & MCL-CA & na & AL-US & SMCL-CA & AL-US \\
\hline Threshold & 1,000 & 6 & 10 & 1,000 & 4 & 1,000 & 5 & 50 & na & 1,300 & 300 & 15 \\
\hline [LRL/SRL] & '11.6] & {$[0.04]$} & {$[0.06]$} & ${ }^{1}[0.36]$ & {$[0.02]$} & [4] & {$[0.02]$} & '[0.42] & {$[0.02]$} & ${ }^{1}[1.7]$ & '[6] & ${ }^{1}[0.65]$ \\
\hline \multicolumn{13}{|c|}{ SCl grid wells (35 wells sampled) } \\
\hline LIV-01 & 2.5 & - & 0.33 & 157 & - & 281 & - & 5.0 & 0.03 & $\leq 0.80$ & - & $\leq 0.22$ \\
\hline LIV-02 & - & - & 2.0 & 338 & 0.01 & 124 & - & - & 0.24 & - & 155 & 1.51 \\
\hline LIV-03 & - & - & 0.33 & 265 & - & 304 & - & 3.8 & 0.04 & 11.9 & $\leq 5$ & 4.09 \\
\hline LIV-04 & - & - & 0.56 & 311 & - & 284 & - & 8.2 & 0.03 & $\leq 1.4$ & - & $\leq 0.24$ \\
\hline LIV-05 & - & 0.04 & 0.80 & 255 & - & 309 & - & 8.9 & 0.04 & $\leq 1.3$ & $\leq 5$ & 2.00 \\
\hline LIV-06 & - & 0.06 & 0.75 & 377 & - & $* 1,880$ & - & 4.7 & 0.11 & $\leq 0.73$ & $\leq 5$ & $\leq 0.05$ \\
\hline GIL-01 & - & - & 0.32 & 61 & - & 101 & - & 1.2 & 0.02 & 3.6 & - & $\leq 0.52$ \\
\hline GIL-02 & - & - & 0.26 & 138 & - & 90 & - & 1.1 & 0.02 & $\leq 1.2$ & - & $\leq 0.09$ \\
\hline GIL-03 & - & - & 1.1 & 31 & - & $* 1,080$ & - & 32.2 & 0.13 & 2.1 & - & $\leq 0.32$ \\
\hline GIL-04 & $\leq 1.5$ & - & 8.0 & 74 & 0.01 & 869 & E0.03 & 2.4 & 0.03 & $\leq 0.84$ & 14 & $\leq 0.19$ \\
\hline GIL-05 & - & E0.08 & 0.49 & 55 & - & 135 & - & $\leq 0.4$ & 0.07 & - & 58 & - \\
\hline GIL-06 & - & 0.17 & 0.86 & 150 & E0.004 & 490 & - & - & 0.07 & - & - & $\leq 0.20$ \\
\hline GIL-07 & - & - & 0.12 & 73 & - & 52 & - & 0.78 & 0.04 & $\leq 0.80$ & - & $\leq 0.29$ \\
\hline GIL-08 & - & - & 0.13 & 56 & - & 130 & - & 1.1 & 0.02 & 2.3 & - & $\leq 0.25$ \\
\hline GIL-09 & - & - & 0.17 & 62 & - & 165 & - & 1.4 & 0.04 & $\leq 1.5$ & - & $\leq 0.62$ \\
\hline GIL-10 & - & - & 0.36 & 306 & - & 96 & - & 4.5 & 0.07 & 2.7 & 11 & $\leq 0.62$ \\
\hline GIL-11 & - & - & 0.50 & 262 & - & 103 & - & 1.1 & 0.07 & 2.4 & - & $\leq 0.32$ \\
\hline GIL-12 & $\leq 1.6$ & - & 1.5 & 74 & - & 166 & - & $\leq 0.07$ & 0.03 & - & 78 & $\leq 0.11$ \\
\hline GIL-13 & - & 0.17 & 1.3 & 27 & E0.01 & 886 & E0.03 & $\leq 0.06$ & 0.28 & $\leq 0.78$ & $\leq 6$ & 4.46 \\
\hline GIL-14 & $\leq 1.5$ & - & 0.13 & 35 & E0.01 & 727 & - & - & 0.05 & - & 223 & $\leq 0.06$ \\
\hline GIL-15 & $\leq 1.1$ & 1.5 & 7.7 & 290 & 0.02 & E31 & E0.02 & 6.8 & 0.11 & 4.1 & 16 & 4.73 \\
\hline GIL-16 & $\leq 0.9$ & E0.13 & 2.8 & 30 & E0.01 & 981 & - & 20.6 & 0.03 & 1.9 & - & $\leq 0.30$ \\
\hline GIL-17 & $\leq 1.6$ & E0.13 & 2.3 & 28 & - & E10 & - & 15.9 & 0.04 & 2.7 & 19 & $\leq 0.37$ \\
\hline CUY-01 & - & - & 0.64 & 18 & - & 117 & 0.08 & $\leq 0.35$ & 0.06 & 3.4 & 22 & 5.68 \\
\hline CUY-02 & E2.9 & - & $* 44.0$ & 19 & - & 207 & 0.14 & - & E0.06 & - & 102 & $\leq 0.60$ \\
\hline CUY-03 & - & - & E0.18 & 11 & - & 180 & - & $\leq 0.37$ & 0.13 & - & 13 & $\leq 0.29$ \\
\hline CUY-04 & - & - & 0.18 & 10 & - & 153 & - & 1.3 & 0.14 & 4.7 & - & 1.20 \\
\hline CUY-05 & - & - & 1.6 & 10 & - & 151 & 0.17 & - & 0.12 & - & E14 & $\leq 0.24$ \\
\hline CUY-06 & - & - & 0.32 & 11 & - & 148 & - & $\leq 0.30$ & 0.13 & - & 34 & 2.11 \\
\hline CUY-07 & - & - & 0.19 & 13 & E0.005 & 152 & - & 0.53 & 0.16 & 2.4 & 41 & 0.83 \\
\hline CUY-08 & - & - & 0.18 & 8.0 & - & 137 & - & $\leq 0.31$ & 0.09 & $\leq 0.89$ & $\leq 5$ & $\leq 0.08$ \\
\hline CUY-09 & 2.7 & E0.11 & 9.3 & 98 & - & 41 & - & - & 0.05 & - & 31 & 2.70 \\
\hline CUY-10 & - & E0.08 & $* 10.8$ & 72 & - & 53 & 0.08 & $\leq 0.08$ & 0.07 & - & 46 & $\leq 0.09$ \\
\hline CUY-11 & 3.2 & - & 0.12 & 33 & - & 36 & - & 1.5 & 0.09 & $\leq 0.97$ & - & 0.85 \\
\hline CUY-12 & - & - & 0.37 & 11 & - & 135 & - & $\leq 0.34$ & 0.17 & 1.8 & $\leq 4$ & $\leq 0.48$ \\
\hline
\end{tabular}


Table 8. Trace elements collected for the South Coast Interior Basins Groundwater Ambient Monitoring and Assessment (GAMA) study, California, August to December 2008. - Continued

[The five-digit U.S. Geological Survey (USGS) parameter code below the constituent name is used to uniquely identify a specific constituent or property. Samples from all 54 wells were analyzed. Information about the analytes given in table $3 F$. GAMA well identification number: LIV, Livermore study area grid well; LIVU, Livermore study area understanding well; GIL, Gilroy study area grid well; GILU, Gilroy study area understanding well; CUY, Cuyama study area grid well; CUYU, Cuyama study area understanding well. Threshold type and threshold level as of November 17, 2008. Threshold type: Maximum contaminant level thresholds are listed as MCL-US when the MCL-US and MCL-CA are identical, and as MCL-CA when the MCL-CA is lower than the MCL-US or no MCL-US exists. AL-US, U.S. Environmental Protection Agency action level; HAL-US, U.S. Environmental Protection Agency lifetime health advisory level; MCL-CA, California Department of Public Health maximum contaminant level; MCL-US, U.S. Environmental Protection Agency maximum contaminant level; NL-CA, California Department of Public Health notification level; SMCL-CA, California Department of Public Health secondary maximum contaminant level. Abbreviations: E, estimated or having a higher degree of uncertainty; LRL, laboratory reporting level; SRL, study reporting limit; $\mu \mathrm{g} / \mathrm{L}$, microgram per liter; na, not available; - , not detected; $\leq$ less than or equal to; *, value above threshold level]

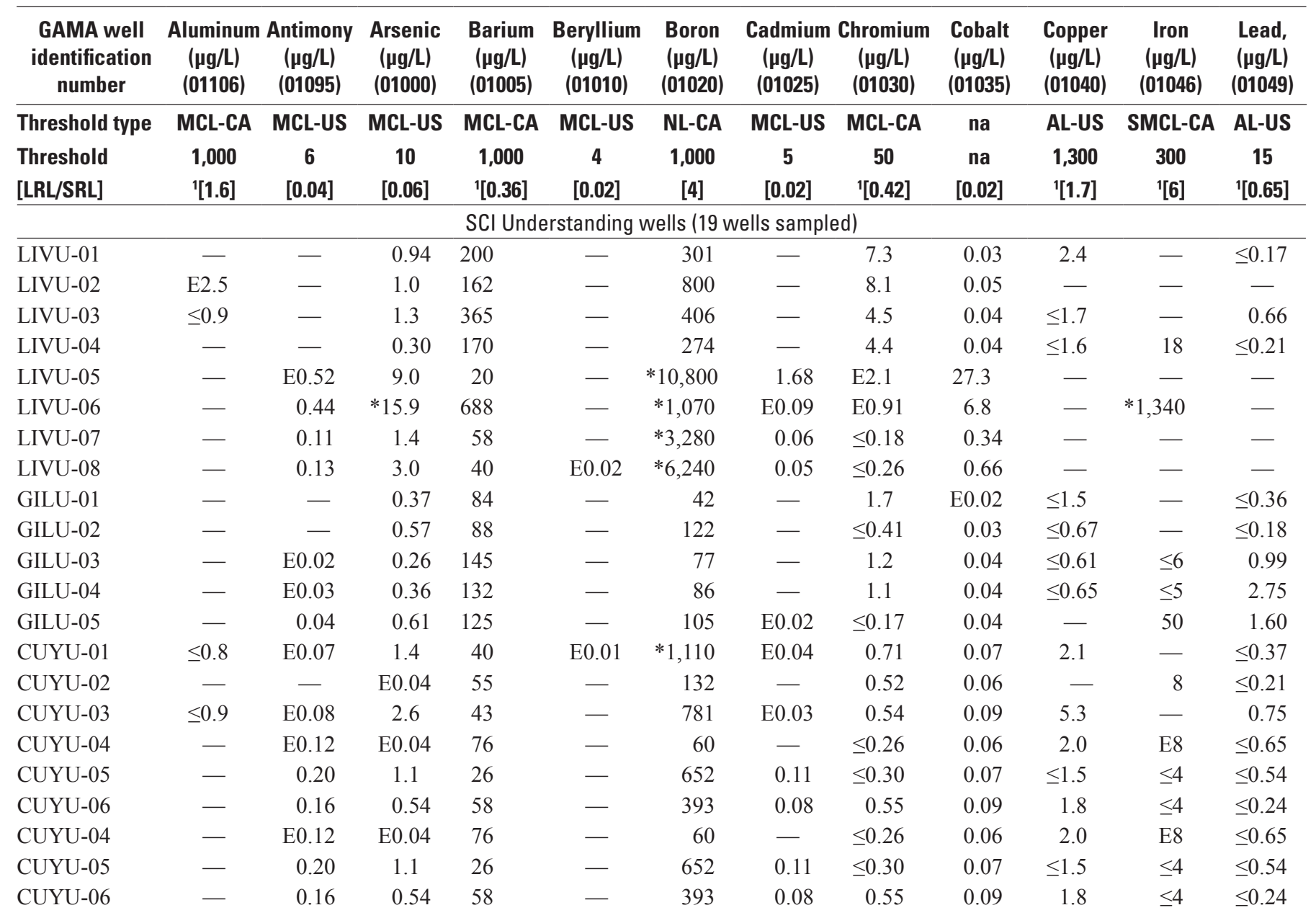


Table 8. Trace elements collected for the South Coast Interior Basins Groundwater Ambient Monitoring and Assessment (GAMA) study, California, August to December 2008.-Continued

[The five-digit U.S. Geological Survey (USGS) parameter code below the constituent name is used to uniquely identify a specific constituent or property. Samples from all 54 wells were analyzed. Information about the analytes given in table $3 F$. GAMA well identification number: LIV, Livermore study area grid well; LIVU, Livermore study area understanding well; GIL, Gilroy study area grid well; GILU, Gilroy study area understanding well; CUY, Cuyama study area grid well; CUYU, Cuyama study area understanding well. Threshold type and threshold level as of November 17, 2008. Threshold type: Maximum contaminant level thresholds are listed as MCL-US when the MCL-US and MCL-CA are identical, and as MCL-CA when the MCL-CA is lower than the MCL-US or no MCL-US exists. AL-US, U.S. Environmental Protection Agency action level; HAL-US, U.S. Environmental Protection Agency lifetime health advisory level; MCL-CA, California Department of Public Health maximum contaminant level; MCL-US, U.S. Environmental Protection Agency maximum contaminant level; NL-CA, California Department of Public Health notification level; SMCL-CA, California Department of Public Health secondary maximum contaminant level. Abbreviations: E, estimated or having a higher degree of uncertainty; LRL, laboratory reporting level; SRL, study reporting limit; $\mu \mathrm{g} / \mathrm{L}$, microgram per liter; na, not available; - , not detected; $\leq$, less than or equal to; *, value above threshold level]

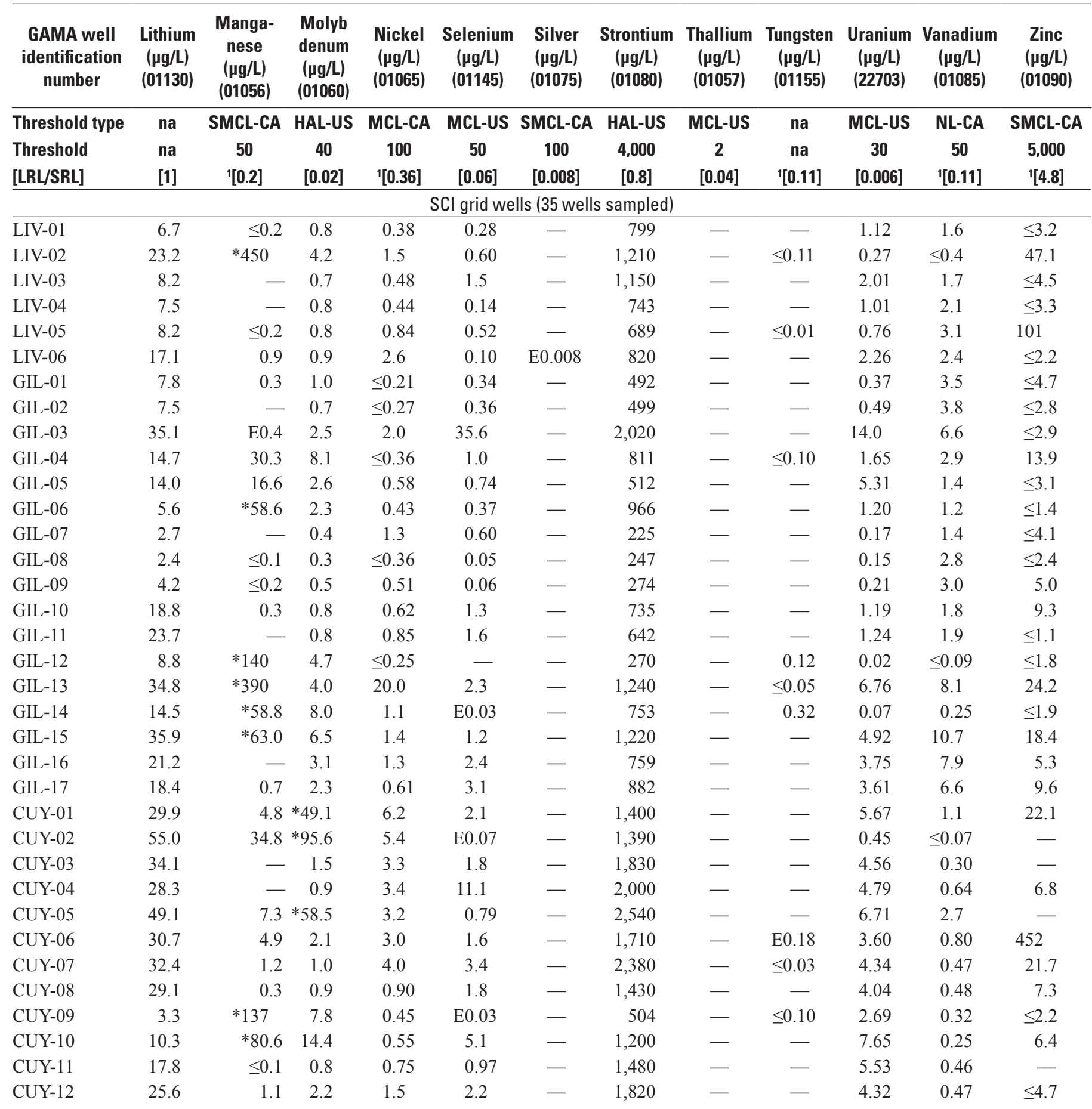


Table 8. Trace elements collected for the South Coast Interior Basins Groundwater Ambient Monitoring and Assessment (GAMA) study, California, August to December 2008.-Continued

[The five-digit U.S. Geological Survey (USGS) parameter code below the constituent name is used to uniquely identify a specific constituent or property. Samples from all 54 wells were analyzed. Information about the analytes given in table $3 F$. GAMA well identification number: LIV, Livermore study area grid well; LIVU, Livermore study area understanding well; GIL, Gilroy study area grid well; GILU, Gilroy study area understanding well; CUY, Cuyama study area grid well; CUYU, Cuyama study area understanding well. Threshold type and threshold level as of November 17, 2008. Threshold type: Maximum contaminant level thresholds are listed as MCL-US when the MCL-US and MCL-CA are identical, and as MCL-CA when the MCL-CA is lower than the MCL-US or no MCL-US exists. AL-US, U.S. Environmental Protection Agency action level; HAL-US, U.S. Environmental Protection Agency lifetime health advisory level; MCL-CA, California Department of Public Health maximum contaminant level; MCL-US, U.S. Environmental Protection Agency maximum contaminant level; NL-CA, California Department of Public Health notification level; SMCL-CA, California Department of Public Health secondary maximum contaminant level. Abbreviations: E, estimated or having a higher degree of uncertainty; LRL, laboratory reporting level; SRL, study reporting limit; $\mu \mathrm{g} / \mathrm{L}$, microgram per liter; na, not available; - , not detected; $\leq$, less than or equal to; *, value above threshold level]

\begin{tabular}{|c|c|c|c|c|c|c|c|c|c|c|c|c|}
\hline $\begin{array}{c}\text { GAMA well } \\
\text { identification } \\
\text { number }\end{array}$ & $\begin{array}{c}\text { Lithium } \\
\text { ( } \mu \mathrm{g} / \mathrm{L}) \\
(01130)\end{array}$ & $\begin{array}{c}\text { Manga- } \\
\text { nese } \\
(\mu \mathrm{g} / \mathrm{L}) \\
(01056)\end{array}$ & $\begin{array}{c}\text { Molyb- } \\
\text { denum } \\
(\mu \mathrm{g} / \mathrm{L}) \\
(01060)\end{array}$ & $\begin{array}{c}\text { Nickel } \\
\text { ( } \mu \mathrm{gg} / \mathrm{L}) \\
(01065)\end{array}$ & $\begin{array}{c}\text { Selenium } \\
(\mu \mathrm{g} / \mathrm{L}) \\
(01145)\end{array}$ & $\begin{array}{c}\text { Silver } \\
\text { ( } \mu g / \mathrm{L}) \\
(01075)\end{array}$ & $\begin{array}{c}\text { Strontium } \\
(\mu \mathrm{g} / \mathrm{L}) \\
(01080)\end{array}$ & $\begin{array}{c}\text { Thallium } \\
(\mu \mathrm{g} / \mathrm{L}) \\
(01057)\end{array}$ & $\begin{array}{c}\text { Tungsten } \\
(\mu \mathrm{g} / \mathrm{L}) \\
(01155)\end{array}$ & $\begin{array}{c}\text { Uranium } \\
\text { ( } \mu \mathrm{g} / \mathrm{L}) \\
(22703)\end{array}$ & $\begin{array}{c}\text { Vanadium } \\
(\mu \mathrm{g} / \mathrm{L}) \\
(01085)\end{array}$ & $\begin{array}{c}\text { Zinc } \\
(\mu \mathrm{g} / \mathrm{L}) \\
(01090)\end{array}$ \\
\hline Threshold type & na & SMCL-CA & HAL-US & MCL-CA & MCL-US & SMCL-CA & HAL-US & MCL-US & na & MCL-US & NL-CA & SMCL-CA \\
\hline Threshold & na & 50 & 40 & 100 & 50 & 100 & 4,000 & 2 & na & 30 & 50 & 5,000 \\
\hline [LRL/SRL] & [1] & ${ }^{1}[0.2]$ & {$[0.02]$} & ${ }^{1}[0.36]$ & {$[0.06]$} & [0.008] & [0.8] & [0.04] & ${ }^{1}[0.11]$ & {$[0.006]$} & ${ }^{1}[0.11]$ & $14.8]$ \\
\hline LIVU-01 & 8.1 & $\leq 0.2$ & 1.4 & $\leq 0.33$ & 4.8 & - & 855 & - & - & 2.00 & 3.6 & $\leq 1.4$ \\
\hline LIVU-02 & 9.5 & $\leq 0.2$ & 1.0 & 0.99 & 1.0 & - & 774 & - & - & 2.44 & 3.6 & - \\
\hline LIVU-03 & 11.0 & - & 1.1 & 0.68 & 8.2 & - & 1,230 & - & - & 2.87 & 5.1 & $\leq 1.5$ \\
\hline LIVU-04 & 5.7 & 0.9 & 0.7 & 0.47 & 0.13 & - & 854 & - & - & 0.77 & 1.2 & 334 \\
\hline LIVU-05 & 146 & $* 17,500$ & $* 123$ & 29.0 & E1.0 & E0.1 & $* 20,000$ & - & - & $* 138$ & 27.9 & - \\
\hline GILU-02 & 9.2 & 5.8 & 6.3 & 1.8 & 0.76 & - & 363 & - & - & 0.53 & 4.9 & $\leq 2.5$ \\
\hline GILU-03 & 7.7 & 2.0 & 0.6 & 0.65 & 0.13 & - & 419 & - & $\leq 0.01$ & 0.35 & 2.6 & 45.2 \\
\hline GILU-04 & 9.4 & 2.3 & 0.7 & 0.59 & 0.22 & - & 436 & - & - & 0.33 & 2.3 & 32.7 \\
\hline GILU-05 & 10.8 & $* 148$ & 5.2 & 0.78 & 0.74 & - & 556 & - & $\leq 0.07$ & 0.56 & 2.9 & 30.8 \\
\hline CUY-01 & 27.4 & $<0.2$ & 20.7 & 0.76 & 1.1 & - & 1,240 & - & - & 23.9 & 0.96 & 48.3 \\
\hline CUYU-02 & 20.5 & $\leq 0.2$ & 4.3 & 1.2 & 0.76 & - & 1,920 & - & - & 6.03 & 0.12 & 35.4 \\
\hline CUYU-03 & 18.9 & $\leq 0.1$ & 8.0 & 0.80 & 1.5 & - & 1,440 & - & $\leq 0.04$ & 16.7 & 1.8 & 11.5 \\
\hline CUYU-04 & 3.6 & $\leq 0.1$ & 0.5 & 0.85 & 0.32 & - & 783 & - & - & 4.83 & 0.57 & 12.2 \\
\hline CUYU-05 & 26.0 & 0.4 & 36.0 & 0.65 & 0.57 & - & 1,120 & - & $\leq 0.03$ & 26.4 & 0.61 & 61.6 \\
\hline CUYU-06 & 22.5 & $\leq 0.2$ & 23.6 & 0.87 & 0.47 & E0.006 & 1,030 & - & $\leq 0.06$ & 20.3 & 1.0 & 8.3 \\
\hline
\end{tabular}

${ }^{1}$ Study reporting limit (SRL) defined based on examination of GAMA quality-control samples collected from May 2004 through January 2008 (L.D. Olsen and M.S. Fram, U.S. Geological Survey, written commun., 2009). Values below SRL are reported as less than or equal to the value reported by the laboratory $(\leq)$. In the USGS NWIS database, the result is accompanied with the following comment: Result is $<$ or = reported value, based on QC data (may include: field blanks, source-solution blanks, trip blanks, NWQL set blanks, NWQL blank water certificates, and USGS BQS Blind Blank Program data). 
Table 9. Nutrients detected in samples collected for the South Coast Interior Basins Groundwater Ambient Monitoring and Assessment (GAMA) study, California, August to December 2008.

[The five-digit USGS parameter code below the constituent name is used to uniquely identify a specific constituent or property. Samples from all 54 wells were analyzed. Information about the analytes given in table $3 G$. GAMA well identification number: LIV, Livermore study area grid well; LIVU, Livermore study area understanding well; GIL, Gilroy study area grid well; GILU, Gilroy study area understanding well; CUY, Cuyama study area grid well; CUYU, Cuyama study area understanding well. Threshold type and threshold level as of November 17, 2008. Threshold type: Maximum contaminant level thresholds are listed as MCL-US when the MCL-US and MCL-CA are identical, and as MCL-CA when the MCL-CA is lower than the MCL-US or no MCL-US exists. HAL-US, U.S. Environmental Protection Agency lifetime health advisory level; MCL-US, U.S. Environmental Protection Agency maximum contaminant level. Abbreviations: E, estimated or having a higher degree of uncertainty; LRL, laboratory reporting level; mg/L, milligram per liter; na, not available; - , not detected; *, value above threshold level]

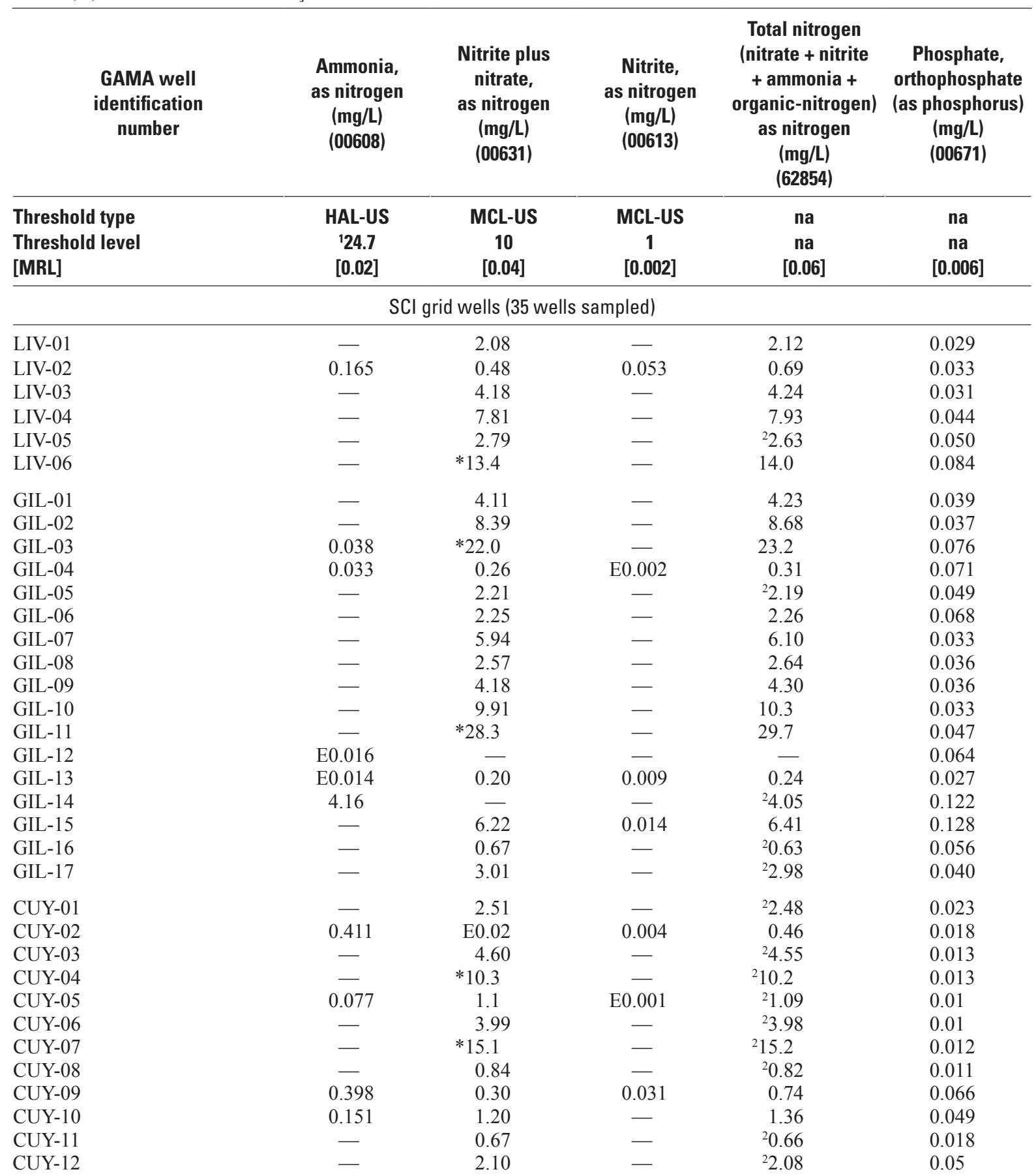


Table 9. Nutrients detected in samples collected for the South Coast Interior Basins Groundwater Ambient Monitoring and Assessment (GAMA) study, California, August to December 2008.-Continued

[The five-digit USGS parameter code below the constituent name is used to uniquely identify a specific constituent or property. Samples from all 54 wells were analyzed. Information about the analytes given in table $3 G$. GAMA well identification number: LIV, Livermore study area grid well; LIVU, Livermore study area understanding well; GIL, Gilroy study area grid well; GILU, Gilroy study area understanding well; CUY, Cuyama study area grid well; CUYU, Cuyama study area understanding well. Threshold type and threshold level as of November 17, 2008. Threshold type: Maximum contaminant level thresholds are listed as MCL-US when the MCL-US and MCL-CA are identical, and as MCL-CA when the MCL-CA is lower than the MCL-US or no MCL-US exists. HAL-US, U.S. Environmental Protection Agency lifetime health advisory level; MCL-US, U.S. Environmental Protection Agency maximum contaminant level. Abbreviations: E, estimated or having a higher degree of uncertainty; LRL, laboratory reporting level; mg/L, milligram per liter; na, not available; - , not detected; *, value above threshold level]

\begin{tabular}{|c|c|c|c|c|c|}
\hline $\begin{array}{c}\text { GAMA well } \\
\text { identification } \\
\text { number }\end{array}$ & $\begin{array}{c}\text { Ammonia, } \\
\text { as nitrogen } \\
(\mathrm{mg} / \mathrm{L}) \\
(00608)\end{array}$ & $\begin{array}{c}\text { Nitrite plus } \\
\text { nitrate, } \\
\text { as nitrogen } \\
(\mathrm{mg} / \mathrm{L}) \\
(00631)\end{array}$ & $\begin{array}{c}\text { Nitrite, } \\
\text { as nitrogen } \\
(\mathrm{mg} / \mathrm{L}) \\
(00613)\end{array}$ & $\begin{array}{c}\text { Total nitrogen } \\
\text { (nitrate + nitrite } \\
\text { + ammonia + } \\
\text { organic-nitrogen) } \\
\text { as nitrogen } \\
\text { (mg/L) } \\
(62854)\end{array}$ & $\begin{array}{c}\text { Phosphate, } \\
\text { orthophosphate } \\
\text { (as phosphorus) } \\
\text { (mg/L) } \\
\text { (00671) }\end{array}$ \\
\hline Threshold type & HAL-US & MCL-US & MCL-US & na & na \\
\hline $\begin{array}{l}\text { Threshold level } \\
\text { [MRL] }\end{array}$ & $\begin{array}{c}124.7 \\
{[0.02]}\end{array}$ & $\begin{array}{c}10 \\
{[0.04]}\end{array}$ & $\begin{array}{c}1 \\
{[0.002]}\end{array}$ & $\begin{array}{c}\text { na } \\
{[0.06]}\end{array}$ & $\begin{array}{c}\text { na } \\
{[0.006]}\end{array}$ \\
\hline \multicolumn{6}{|c|}{ SCI understanding wells (19 grid wells sampled) } \\
\hline LIVU-01 & - & 3.33 & - & 23.20 & 0.053 \\
\hline LIVU-02 & - & 7.41 & - & 7.54 & 0.066 \\
\hline LIVU-03 & - & 4.37 & - & 4.46 & 0.072 \\
\hline LIVU-04 & - & 2.15 & - & 2.25 & 0.019 \\
\hline LIVU-05 & 0.916 & E0.02 & E0.002 & 1.26 & 0.212 \\
\hline LIVU-06 & 1.42 & - & E0.001 & ${ }^{2} 1.34$ & 0.186 \\
\hline LIVU-07 & - & - & - & 0.10 & 0.128 \\
\hline LIVU-08 & E0.017 & - & - & 0.13 & 0.132 \\
\hline GILU-01 & - & 6.65 & - & 7.20 & 0.063 \\
\hline GILU-02 & - & 4.19 & 0.007 & 4.31 & 0.063 \\
\hline GILU-03 & - & 5.98 & 0.003 & ${ }^{2} 5.79$ & 0.043 \\
\hline GILU-04 & - & 5.80 & 0.017 & ${ }^{2} 5.76$ & 0.029 \\
\hline GILU-05 & 0.25 & 2.25 & 0.08 & ${ }^{2} 2.43$ & 0.063 \\
\hline CUYU-01 & - & 2.62 & - & 2.67 & 0.009 \\
\hline CUYU-02 & - & 0.65 & - & 0.65 & E0.004 \\
\hline CUYU-03 & - & 1.64 & - & 1.65 & 0.051 \\
\hline CUYU-04 & - & 0.48 & - & 0.48 & 0.007 \\
\hline CUYU-05 & - & 4.20 & - & ${ }^{2} 3.96$ & E0.006 \\
\hline CUYU-06 & - & 4.17 & - & ${ }^{2} 4.10$ & E0.008 \\
\hline
\end{tabular}

${ }^{1}$ The HAL-US is $30 \mathrm{mg} / \mathrm{L}$ "as ammonia." To facilitate comparson to the analytical results, we have converted and reported this HAL-US as $24.7 \mathrm{mg} / \mathrm{L}$ "as nitrogen."

${ }^{2}$.Total nitrogen in these samples is less than the sum of the filtered nitrogen analytes, but falls within the U.S. Geological Survey National Water Quality Laboratory acceptance criteria of a 10 percent or less relative percent difference. 
Table 10. Major and minor ions, silica, and total dissolved solids (TDS) detected in samples collected for the South Coast Interior Basins Groundwater Ambient Monitoring and Assessment (GAMA) study, California, August to December 2008.

[The five-digit USGS parameter code below the constituent name is used to uniquely identify a specific constituent or property. Samples from all 54 were analyzed. Information about the analytes given in table $3 H$. GAMA well identification number: LIV, Livermore study area grid well; LIVU, Livermore study area understanding well; GIL, Gilroy study area grid well; GILU, Gilroy study area understanding well; CUY, Cuyama study area grid well; CUYU, Cuyama study area understanding well. Threshold type and threshold level as of November 17, 2008. Threshold type: Maximum contaminant level thresholds are listed as MCL-US when the MCL-US and MCL-CA are identical, and as MCL-CA when the MCL-CA is lower than the MCL-US or no MCL-US exists. MCL-CA, California Department of Public Health maximum contaminant level; SMCL-CA, California Department of Public Health secondary maximum contaminant level. Abbreviations: LRL, laboratory reporting level; mg/L, milligrams per liter; E, estimated or having a higher degree of uncertainty; na, not available; - , not detected; *, value above threshold level; **, value above upper threshold level]

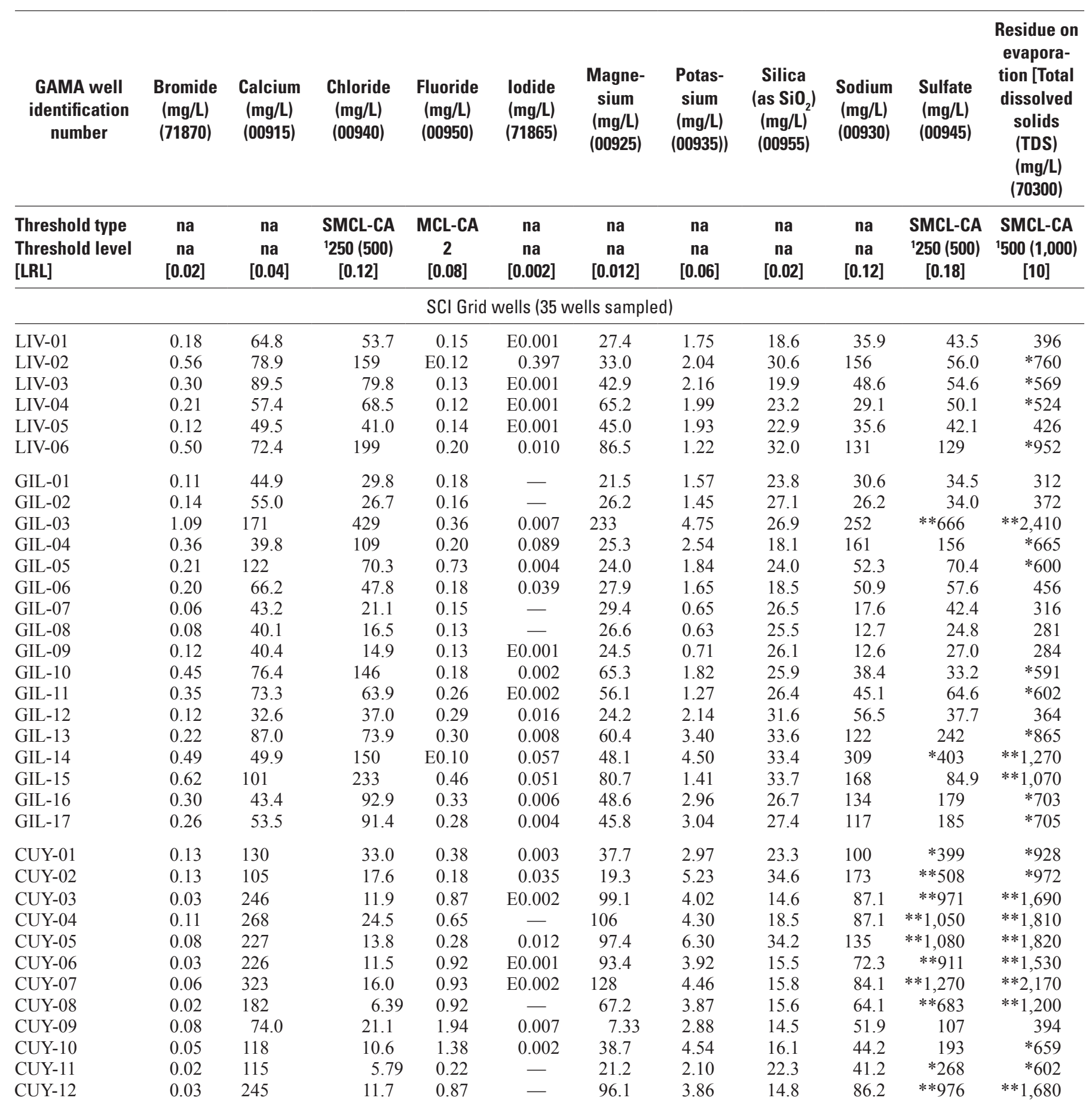


Table 10. Major and minor ions, silica, and total dissolved solids (TDS) detected in samples collected for the South Coast Interior Basins Groundwater Ambient Monitoring and Assessment (GAMA) study, California, August to December 2008.-Continued

[The five-digit USGS parameter code below the constituent name is used to uniquely identify a specific constituent or property. Samples from all 54 were analyzed. Information about the analytes given in table $3 \mathrm{H}$. GAMA well identification number: LIV, Livermore study area grid well; LIVU, Livermore study area understanding well; GIL, Gilroy study area grid well; GILU, Gilroy study area understanding well; CUY, Cuyama study area grid well; CUYU, Cuyama study area understanding well. Threshold type and threshold level as of November 17, 2008. Threshold type: Maximum contaminant level thresholds are listed as MCL-US when the MCL-US and MCL-CA are identical, and as MCL-CA when the MCL-CA is lower than the MCL-US or no MCL-US exists. MCL-CA, California Department of Public Health maximum contaminant level; SMCL-CA, California Department of Public Health secondary maximum contaminant level. Abbreviations: LRL, laboratory reporting level; mg/L, milligrams per liter; E, estimated or having a higher degree of uncertainty; na, not available; - , not detected; *, value above threshold level; **, value above upper threshold level]

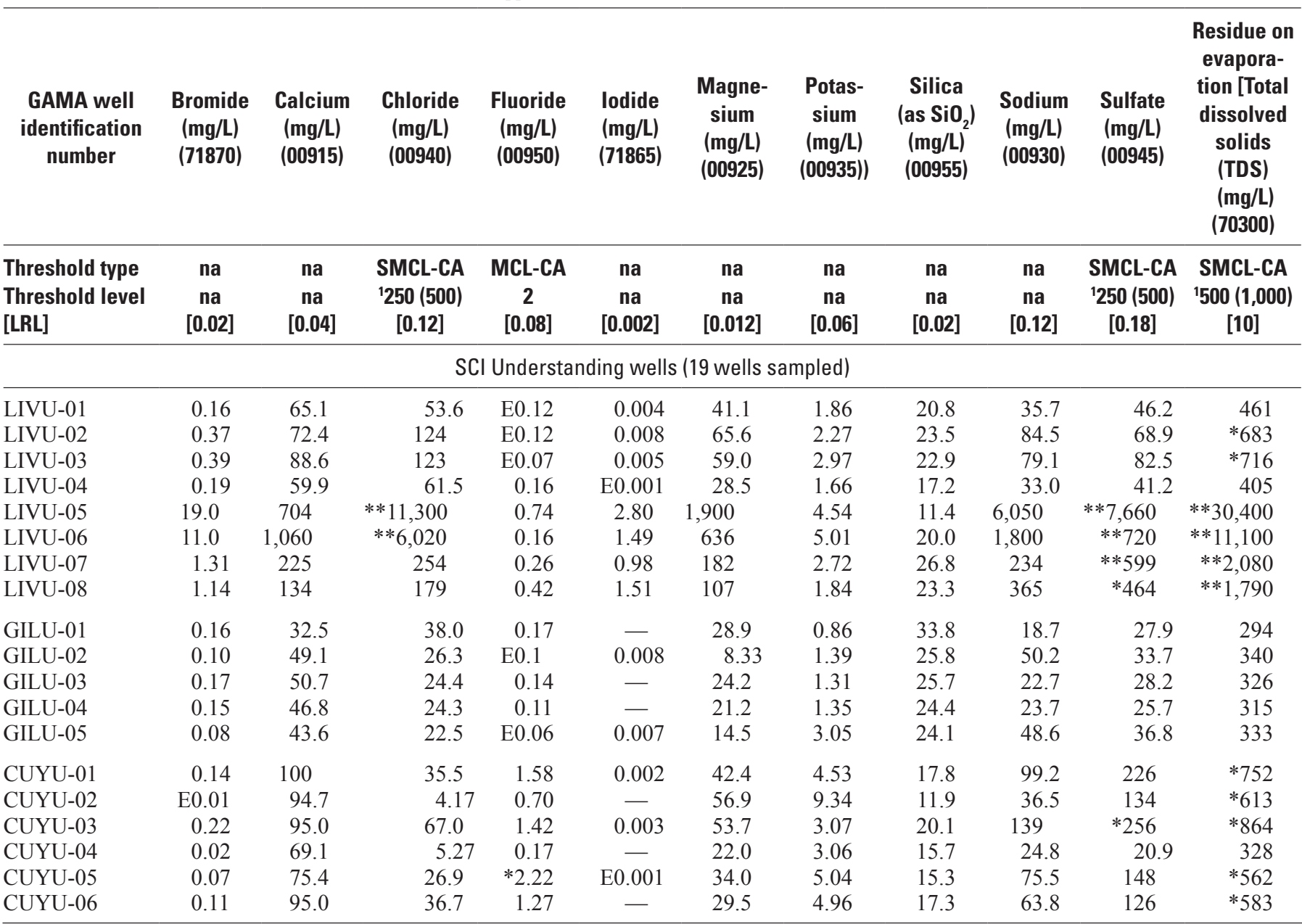

${ }^{1}$ The SMCL-CA for chloride, sulfate, and total dissolved solids (TDS) have recommended and upper threshold values. The upper value is shown in parentheses. 
Table 11. Species of inorganic arsenic, chromium, and iron detected in samples collected for the South Coast Interior Basins Groundwater Ambient Monitoring and Assessment (GAMA) study, California, August to December 2008.

[Data in this table analyzed at U.S. Geological Survey Trace Metals Laboratory using research methods and are not stored in the USGS NWIS database. Information about the analytes given in table 3I. Samples from the 11 slow wells were analyzed; only wells with at least one detection are listed. GAMA well identification number: LIV, Livermore study area grid well; LIVU, Livermore study area understanding well; GIL, Gilroy study area grid well; CUY, Cuyama study area grid well; CUYU, Cuyama study area understanding well. Threshold type and threshold level as of November 17, 2008. Threshold type: Maximum contaminant level thresholds are listed as MCL-US when the MCL-US and MCL-CA are identical, and as MCL-CA when the MCL-CA is lower than the MCL-US or no MCL-US exists. MCL-US, U.S. Environmental Protection Agency maximum contaminant level; MCL-CA, California Department of Public Health maximum contaminant level; SMCL-CA, California Department of Public Health secondary maximum contaminant level. Abbreviations: MDL, method detection limit; $\mu \mathrm{g} / \mathrm{L}$, microgram per liter; na, not available; —, not detected]

\begin{tabular}{|c|c|c|c|c|c|c|}
\hline $\begin{array}{c}\text { GAMA well } \\
\text { identification } \\
\text { number }\end{array}$ & $\begin{array}{c}\text { Arsenic } \\
\text { ( } \mu \mathrm{g} / \mathrm{L})\end{array}$ & $\begin{array}{c}\text { Arsenic (III) } \\
(\mu \mathrm{g} / \mathrm{L})\end{array}$ & $\begin{array}{l}\text { Chromium } \\
(\mu \mathrm{g} / \mathrm{L})\end{array}$ & $\begin{array}{l}\text { Chromium (VI) } \\
(\mu \mathrm{g} / \mathrm{L})\end{array}$ & $\begin{array}{l}\text { Iron } \\
(\mu \mathrm{g} / \mathrm{L})\end{array}$ & $\begin{array}{c}\text { Iron (II) } \\
\text { ( } \mu \mathrm{g} / \mathrm{L})\end{array}$ \\
\hline Threshold type & MCL-US & na & MCL-CA & na & SMCL-CA & na \\
\hline $\begin{array}{l}\text { Threshold level } \\
\text { [MDL] }\end{array}$ & $\begin{array}{c}10 \\
{[0.5]}\end{array}$ & $\begin{array}{l}\text { na } \\
{[1]}\end{array}$ & $\begin{array}{c}50 \\
{[1]}\end{array}$ & $\begin{array}{l}\text { na } \\
{[1]}\end{array}$ & $\begin{array}{l}300 \\
{[2]}\end{array}$ & $\begin{array}{l}\text { na } \\
{[2]}\end{array}$ \\
\hline \multicolumn{7}{|c|}{ SCI Grid wells (7 wells sampled) } \\
\hline LIV-05 & 0.59 & - & 9 & 8 & 12 & - \\
\hline LIV-06 & - & - & 5 & 5 & 8 & - \\
\hline GIL-09 & - & - & 1 & - & 4 & - \\
\hline CUY-02 & $\mathrm{na}^{1}$ & $\mathrm{na}^{1}$ & $\mathrm{na}^{1}$ & $\mathrm{na}^{1}$ & $\mathrm{na}^{1}$ & $\mathrm{na}^{1}$ \\
\hline CUY-04 & $\mathrm{na}^{1}$ & $\mathrm{na}^{1}$ & $\mathrm{na}^{1}$ & $\mathrm{na}^{1}$ & $\mathrm{na}^{1}$ & $\mathrm{na}^{1}$ \\
\hline CUY-09 & $\mathrm{na}^{1}$ & $\mathrm{na}^{1}$ & $\mathrm{na}^{1}$ & $\mathrm{na}^{1}$ & $\mathrm{na}^{1}$ & $\mathrm{na}^{1}$ \\
\hline CUY-10 & $\mathrm{na}^{1}$ & $\mathrm{na}^{1}$ & $\mathrm{na}^{1}$ & $n a^{1}$ & $\mathrm{na}^{1}$ & $n a^{1}$ \\
\hline \multicolumn{7}{|c|}{ SCI Understanding wells (4 wells sampled) } \\
\hline LIVU-02 & 0.74 & - & 10 & 10 & - & - \\
\hline LIVU-03 & 0.89 & - & 6 & 5 & - & - \\
\hline CUYU-06 & $\mathrm{na}^{1}$ & $\mathrm{na}^{1}$ & $\mathrm{na}^{1}$ & $\mathrm{na}^{1}$ & $\mathrm{na}^{1}$ & na ${ }^{1}$ \\
\hline
\end{tabular}

${ }^{1}$ Analyses at the U.S. Geological Survey Trace Metals Laboratory were not completed in time for inclusion in this report; complete results will be presented in a subsequent publication. 
Table 12. Results for analyses of stable isotope ratios and tritium and carbon-14 activities detected in samples collected for the South Coast Interior Basins Groundwater Ambient Monitoring and Assessment (GAMA) study, California, August to December 2008.

[The five-digit USGS parameter code below the constituent name is used to uniquely identify a specific constituent or property. Samples from all 54 wells were analyzed for stable isotopes of water, tritium, and carbon and carbon activities. Stable isotope ratios are reported in the standard delta notation $(\delta)$, the ratio of a heavier isotope to more common lighter isotope of that element, relative to a standard reference material. Information about the analytes given in table $3 J$. GAMA well identification number: LIV, Livermore study area grid well; LIVU, Livermore study area understanding well; GIL, Gilroy study area grid well; GILU, Gilroy study area understanding well; CUY, Cuyama study area grid well; CUYU, Cuyama study area understanding well. Threshold type and threshold level as of November 17, 2008. Threshold type: Maximum contaminant level thresholds are listed as MCL-US when the MCL-US and MCL-CA are identical, and as MCL-CA when the MCL-CA is lower than the MCL-US or no MCL-US exists. MCL-CA, California Department of Public Health maximum contaminant level. Abbreviations: na, not available; —, not detected; $\mathrm{pCi} / \mathrm{L}$, picocuries per liter]

\begin{tabular}{|c|c|c|c|c|c|}
\hline $\begin{array}{c}\text { GAMA well } \\
\text { identification } \\
\text { number }\end{array}$ & $\begin{array}{c}\delta^{2} \mathrm{H} \\
\text { (per mil) } \\
(82082) \\
\end{array}$ & $\begin{array}{c}\delta^{18} 0 \\
\text { (per mil) } \\
(82085)\end{array}$ & $\begin{array}{l}\text { Tritium } \\
\text { (pCi/L) } \\
(07000)\end{array}$ & $\begin{array}{c}\delta^{13} \mathrm{C} \\
\text { (per mil) } \\
(82081)\end{array}$ & $\begin{array}{c}\text { Carbon-14 } \\
\text { (percent modern) } \\
\text { (49933) }\end{array}$ \\
\hline Threshold type & na & na & MCL-CA & na & na \\
\hline Threshold level & na & na & 20,000 & na & na \\
\hline \multicolumn{6}{|c|}{ SCI Grid wells (35 wells sampled) } \\
\hline LIV-01 & -47.20 & -6.50 & 11.13 & -16.36 & 98.45 \\
\hline LIV-02 & -46.10 & -6.50 & 8.52 & -11.98 & 80.76 \\
\hline LIV-03 & -46.40 & -6.13 & 15.47 & -11.94 & 66.10 \\
\hline LIV-04 & -56.50 & -7.89 & 20.64 & -14.29 & 94.88 \\
\hline LIV-05 & -55.30 & -7.70 & na $^{1}$ & $\mathrm{na}^{1}$ & na $^{1}$ \\
\hline LIV-06 & -57.90 & -7.48 & $\mathrm{na}^{1}$ & $\mathrm{na}^{1}$ & $\mathrm{na}^{1}$ \\
\hline GIL-01 & $\mathrm{na}^{2}$ & $\mathrm{na}^{2}$ & 3.67 & -13.82 & 73.50 \\
\hline GIL-02 & -38.90 & -5.84 & 5.68 & -15.68 & 86.06 \\
\hline GIL-03 & -43.90 & -5.96 & 4.18 & -15.80 & 94.88 \\
\hline GIL-04 & -49.40 & -6.81 & - & -13.53 & 38.26 \\
\hline GIL-05 & -42.10 & -6.44 & 7.27 & -15.37 & 98.12 \\
\hline GIL-06 & -43.20 & -6.10 & 8.80 & -15.80 & 93.85 \\
\hline GIL-07 & -36.40 & -5.66 & 8.58 & -16.40 & 103.2 \\
\hline GIL-08 & -36.60 & -5.28 & 8.04 & -14.31 & 109.7 \\
\hline GIL-09 & -35.40 & -5.12 & 9.41 & -14.68 & 109.9 \\
\hline GIL-10 & -43.80 & -6.34 & 3.99 & -15.73 & 88.31 \\
\hline GIL-11 & -38.80 & -5.79 & 9.51 & -15.93 & 101.9 \\
\hline GIL-12 & -40.00 & -6.00 & - & -16.05 & 58.95 \\
\hline GIL-13 & -45.30 & -5.80 & 5.90 & -14.11 & 97.66 \\
\hline GIL-14 & -51.40 & -6.91 & - & -14.82 & 20.30 \\
\hline GIL-15 & -42.70 & -5.88 & - & -17.26 & 86.29 \\
\hline GIL-16 & -47.60 & -6.63 & $\mathrm{na}^{1}$ & -13.46 & 65.78 \\
\hline GIL-17 & -49.00 & -6.67 & 0.73 & -13.75 & 76.92 \\
\hline CUY-01 & $\mathrm{na}^{1}$ & $\mathrm{na}^{1}$ & $\mathrm{na}^{1}$ & -11.33 & 72.07 \\
\hline CUY-02 & $\mathrm{na}^{1}$ & $\mathrm{na}^{1}$ & $\mathrm{na}^{1}$ & -7.11 & 1.57 \\
\hline CUY-03 & $\mathrm{na}^{1}$ & $\mathrm{na}^{1}$ & $\mathrm{na}^{1}$ & -12.03 & 92.81 \\
\hline CUY-04 & $\mathrm{na}^{1}$ & $\mathrm{na}^{1}$ & $\mathrm{na}^{1}$ & -10.03 & 63.88 \\
\hline CUY-05 & $\mathrm{na}^{1}$ & $\mathrm{na}^{1}$ & $\mathrm{na}^{1}$ & -5.70 & 4.03 \\
\hline CUY-06 & $\mathrm{na}^{1}$ & $\mathrm{na}^{1}$ & $\mathrm{na}^{1}$ & -11.07 & 86.37 \\
\hline
\end{tabular}


Table 12. Results for analyses of stable isotope ratios and tritium and carbon-14 activities detected in samples collected for the South Coast Interior Basins Groundwater Ambient Monitoring and Assessment (GAMA) study, California, August to December 2008.-Continued

[The five-digit USGS parameter code below the constituent name is used to uniquely identify a specific constituent or property. Samples from all 54 wells were analyzed for stable isotopes of water, tritium, and carbon and carbon activities. Stable isotope ratios are reported in the standard delta notation $(\delta)$, the ratio of a heavier isotope to more common lighter isotope of that element, relative to a standard reference material. Information about the analytes given in table $3 \mathrm{~J}$. GAMA well identification number: LIV, Livermore study area grid well; LIVU, Livermore study area understanding well; GIL, Gilroy study area grid well; GILU, Gilroy study area understanding well; CUY, Cuyama study area grid well; CUYU, Cuyama study area understanding well. Threshold type and threshold level as of November 17, 2008. Threshold type: Maximum contaminant level thresholds are listed as MCL-US when the MCL-US and MCL-CA are identical, and as MCL-CA when the MCL-CA is lower than the MCL-US or no MCL-US exists. MCL-CA, California Department of Public Health maximum contaminant level. Abbreviations: na, not available; —, not detected; $\mathrm{pCi} / \mathrm{L}$, picocuries per liter]

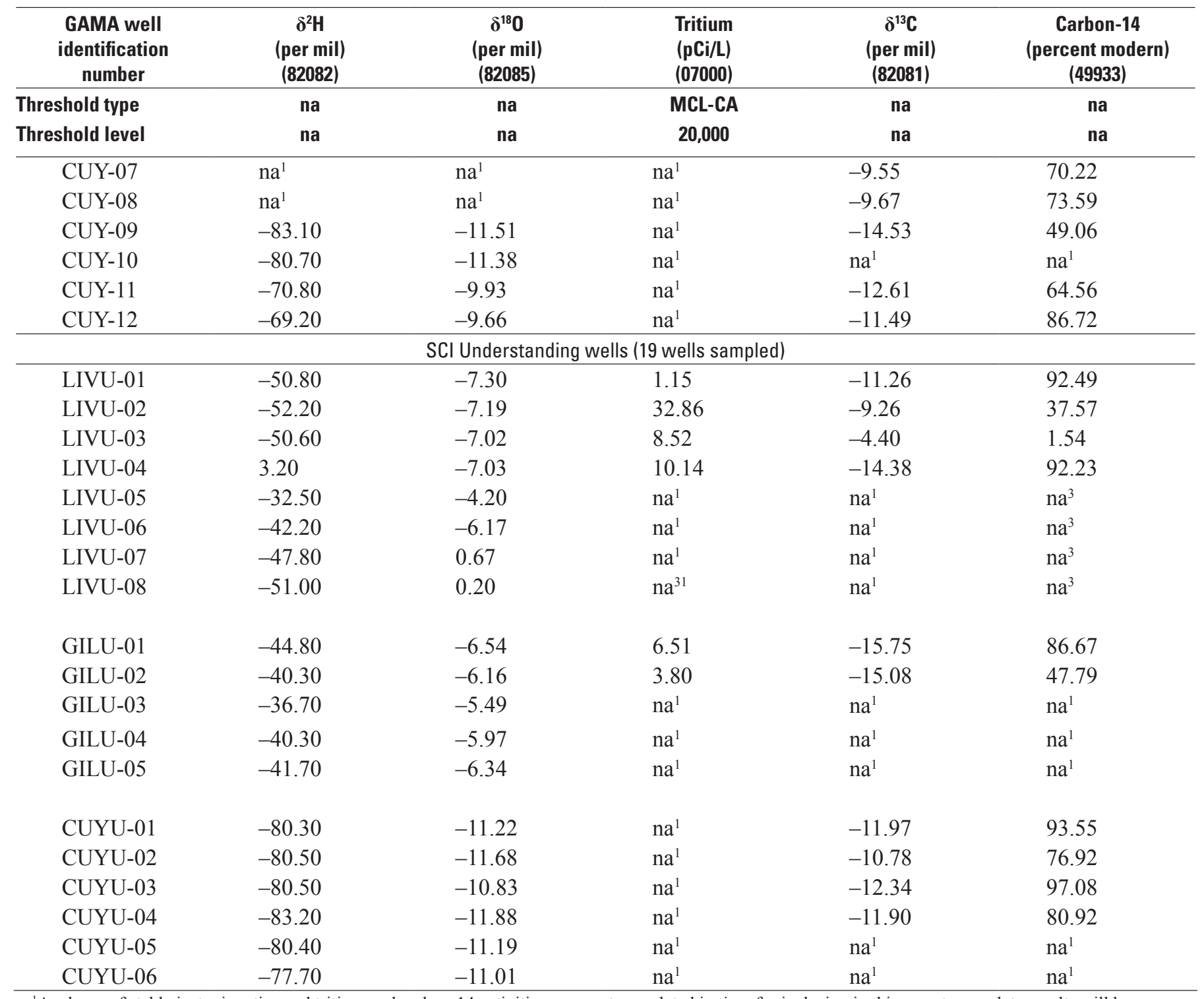

${ }^{1}$ Analyses of stable isotopic ratios and tritium and carbon-14 activities were not completed in time for inclusion in this report; complete results will be presented in a subsequent publication.

${ }^{2}$ Sample arrived at the USGS Stable Isotope Laboratory broken. 
Table 13A. Gross alpha and gross beta radioactivity detected in samples collected for the South Coast Interior Basins Groundwater Ambient Monitoring and Assessment (GAMA) study, California, August to December 2008.

[The five-digit U.S. Geological Survey (USGS) parameter code below the constituent name is used to uniquely identify a specific constituent or property. Samples from the 11 slow wells were analyzed. Information about the analytes given in table $3 \mathrm{~J}$. The reference nuclide for measurement of gross alpha is thorium-230 and the reference nuclide for measurement of gross beta is cesium-137. Measured values less than the sample-specific critical level (ssL $\mathrm{s}_{\mathrm{C}}$ ) are reported as non-detections (-). GAMA well identification number: LIV, Livermore study area grid well; LIVU, Livermore study area understanding well; GIL, Gilroy study area grid well; GILU, Gilroy study area understanding well; CUY, Cuyama study area grid well; CUYU, Cuyama study area understanding well. Threshold type and threshold level as of November 17, 2008. Threshold type: Maximum contaminant level thresholds are listed as MCL-US when the MCL-US and MCL-CA are identical, and as MCL-CA when the MCL-CA is lower than the MCL-US or no MCL-US exists. MCL-CA, California Department of Public Health maximum contaminant level; MCL-US, U.S. Environmental Protection Agency maximum contaminant level. Abbreviations: CSU, 1-sigma combined standard uncertainty; $\mathrm{pCi} / \mathrm{L}$, picocurie per liter; —, not detected; \pm , plus or minus]

\begin{tabular}{|c|c|c|c|c|c|c|c|c|}
\hline $\begin{array}{l}\text { GAMA well identi- } \\
\text { fication number }\end{array}$ & \multicolumn{2}{|c|}{$\begin{array}{c}\text { Gross alpha radioactivity, } \\
\text { 72-hour count } \\
\text { (pCi/L) } \\
\text { (62636) }\end{array}$} & \multicolumn{2}{|c|}{$\begin{array}{c}\text { Gross alpha radioactivity, } \\
\text { 30-day count } \\
\text { (pCi/L) } \\
(62639)\end{array}$} & \multicolumn{2}{|c|}{$\begin{array}{c}\text { Gross beta radioactivity, } \\
\text { 72-hour count } \\
\text { (pCi/L) } \\
(62642)\end{array}$} & \multicolumn{2}{|c|}{$\begin{array}{c}\text { Gross beta radioactivity, } \\
\text { 30-day count } \\
\text { (pCi/L) } \\
(62645)\end{array}$} \\
\hline \multirow{2}{*}{$\begin{array}{l}\text { Threshold type } \\
\text { Threshold level }\end{array}$} & \multirow{2}{*}{\multicolumn{2}{|c|}{$\begin{array}{c}\text { MCL-US } \\
15\end{array}$}} & \multirow{2}{*}{\multicolumn{2}{|c|}{$\begin{array}{c}\text { MCL-US } \\
15\end{array}$}} & \multirow{2}{*}{\multicolumn{2}{|c|}{$\begin{array}{l}\text { MCL-CA } \\
50\end{array}$}} & \multirow{2}{*}{\multicolumn{2}{|c|}{$\begin{array}{c}\text { MCL-CA } \\
50\end{array}$}} \\
\hline & & & & & & & & \\
\hline LIV-05 & $1.34 \pm 0.66$ & 0.80 & - & 1.4 & $1.84 \pm 0.61$ & 0.95 & $1.84 \pm 0.56$ & 0.87 \\
\hline LIV-06 & $ـ^{(1)}$ & 3.0 & - & 3.3 & ${ }^{1} 1.34 \pm 0.60$ & 0.93 & - & 1.4 \\
\hline GIL-09 & - & 0.47 & - & 0.85 & - & 1.0 & - & 1.2 \\
\hline CUY-02 & $4.5 \pm 1.9$ & 2.4 & $4.8 \pm 1.7$ & 2.0 & $5.81 \pm 0.55$ & 0.57 & $5.27 \pm 0.71$ & 1.0 \\
\hline \multicolumn{9}{|c|}{ SCI Understanding wells (4 wells sampled) } \\
\hline LIVU-02 & $5.3 \pm 1.7$ & 2.0 & $2.6 \pm 1.4$ & 1.8 & $4.78 \pm 0.66$ & 0.86 & $4.45 \pm 0.79$ & 1.2 \\
\hline LIVU-03 & $5.1 \pm 1.6$ & 1.7 & $8.8 \pm 1.9$ & 1.4 & $2.94 \pm 0.57$ & 0.78 & $2.72 \pm 0.57$ & 0.81 \\
\hline GILU-02 & $1.39 \pm 0.62$ & 0.77 & - & 1.1 & $1.44 \pm 0.45$ & 0.68 & - & 1.1 \\
\hline CUYU-06 & ${ }^{1} 13.4 \pm 2.3$ & 1.7 & $13.9 \pm 1.9$ & 1.0 & ${ }^{1} 6.36 \pm 0.54$ & 0.48 & $10.5 \pm 0.83$ & 0.82 \\
\hline
\end{tabular}

${ }^{1}$ Counted 4-6 days after collection.

${ }^{2}$ Counted 44-46 days after initial count. 
Table 13B. Radon-222 detected in samples collected for the South Coast Interior Basins Groundwater Ambient Monitoring and Assessment (GAMA) study, California, August to December 2008.

[The five-digit U.S. Geological Survey (USGS) parameter code below the constituent name is used to uniquely identify a specific constituent or property. Samples from five Gilroy study area wells were analyzed. Information about the analytes given in table $3 J$. GAMA well identification number: GIL, Gilroy study area grid well; GILU, Gilroy study area understanding well. Threshold type and threshold level as of November 17, 2008. Threshold type: Maximum contaminant level thresholds are listed as MCL-US when the MCL-US and MCL-CA are identical, and as MCL-CA when the MCL-CA is lower than the MCL-US or no MCL-US exists. MCL-US, U.S. Environmental Protection Agency maximum contaminant level. Abbreviations: 2SCU,

2-sigma combined uncertainty; $\mathrm{pCi} / \mathrm{L}$, picocurie per liter]

\begin{tabular}{|c|c|}
\hline $\begin{array}{c}\text { GAMA well } \\
\text { identification } \\
\text { number }\end{array}$ & $\begin{array}{c}\text { Radon-222 } \\
\text { (pCi/L) } \\
(82303)\end{array}$ \\
\hline Threshold type & Proposed MCL-US \\
\hline \multirow[t]{2}{*}{ Threshold level } & 4,000 \\
\hline & Result $\pm 2 \mathrm{SCU}$ \\
\hline \multicolumn{2}{|c|}{ SCI Grid wells (1 well sampled) } \\
\hline GIL-01 & $720 \pm 43$ \\
\hline \multicolumn{2}{|c|}{ SCI Understanding wells (4 wells sampled) } \\
\hline GILU-01 & $700 \pm 41$ \\
\hline GILU-03 & $690 \pm 41$ \\
\hline GILU-04 & $520 \pm 32$ \\
\hline GILU-05 & $670 \pm 40$ \\
\hline
\end{tabular}




\section{Appendix}

This Appendix includes discussions of the methods used to collect and analyze groundwater samples and report the resulting water-quality data. These methods were selected to obtain representative samples of the groundwater from each well and to minimize the potential for contamination of the samples or bias in the data. Procedures used to collect and assess quality-control data, and the results of the quality-control assessments also are discussed.

\section{Sample Collection and Analysis}

Groundwater samples were collected using standard and modified USGS protocols from the USGS NAWQA program (Koterba and others, 1995), the USGS National Field Manual (U.S. Geological Survey, variously dated), and protocols described by Weiss (1968), Shelton and others (2001), Ball and McClesky (2003a, 2003b), and Wright and others (2005).

Prior to sampling, each well was pumped continuously to purge at least three casing-volumes of water from the well (Wilde and others, 1999). Wells were sampled using Teflon ${ }^{\circ}$ tubing with brass and stainless-steel fittings attached to a sampling point on the well discharge pipe as close to the well-head as possible. The sampling point always was located upstream of any well-head treatment system or water storage tank. If a chlorinating system was attached to the well, the chlorinator was shut off at least 24 hours prior to purging and sampling the well to clear all chlorine out of the system. For the fast schedule, samples were collected at the well head using a foot-long length of Teflon ${ }^{\odot}$ tubing. For the slow schedule, the samples were collected inside an enclosed chamber located inside a mobile laboratory and connected to the well head by a $10-50 \mathrm{ft}$ length of the Teflon ${ }^{\odot}$ tubing (Lane and others, 2003). All fittings and lengths of tubing were cleaned between samples (Wilde, 2004).

For the field measurements, groundwater was pumped through a flow-through chamber fitted with a multi-probe meter that simultaneously measures the water-quality indicators (field parameters) - dissolved oxygen, temperature, $\mathrm{pH}$, and specific conductance. Turbidity was measured in the field with a calibrated turbidity meter. Field measurements were made in accordance with protocols in the USGS National Field Manual (Radtke and others, 2005; Wilde and Radtke, 2005; Lewis, 2006; Wilde, 2006; Wilde and others, 2006). All sensors on the multi-probe meter were calibrated daily. Measured temperature, dissolved oxygen, $\mathrm{pH}$, specific conductance and turbidity values were recorded at 5-minute intervals for at least 30 minutes, and when these values remained stable for 20 minutes, samples for laboratory analyses then were collected.
Field measurements and instrument calibrations were recorded by hand on field record sheets and electronically in PCFF, a software package designed by the USGS with support from the GAMA Program. Analytical service requests also were managed by PCFF. Information from PCFF was uploaded directly into NWIS at the end of every week of sample collection.

For analyses requiring filtered water, groundwater was diverted through a disk filter, a baked $0.3-\mu \mathrm{m}$ nominal pore-size glass-fiber filter, or a $0.45-\mu \mathrm{m}$ pore-size What$\operatorname{man}^{\mathcal{O}}$ vented capsule filter, depending on the protocol for the analysis (Wilde and others, 1999, 2004). Prior to sample collection, polyethylene sample bottles were pre-rinsed two times using deionized water, and then once with sample water before sample collection. Samples requiring acidification were acidified to a $\mathrm{pH}$ of 2 or less with the appropriate acids using ampoules of certified, traceable concentrated acids obtained from the NWQL.

Temperature-sensitive samples were stored on ice prior to, and during daily shipping to the various laboratories. The nontemperature-sensitive samples for chromium speciation, stable isotopes of hydrogen and oxygen in water, tritium, and noble gases were shipped monthly, while temperaturesensitive samples for volatile organic compounds, pesticides, polar pesticides, perchlorate, NDMA, trace elements, nutrients, major and minor ions, silica, TDS, gross alpha and gross beta radioactivity, and radon-222 were shipped daily. The temperature-sensitive samples for arsenic and iron speciation were stored on ice, archived in a laboratory refrigerator, and shipped after results for the metal concentrations were received from the NWQL.

Detailed sampling protocols for individual analyses and groups of analytes are described in Koterba and others (1995), the USGS National Field Manual (Wilde and others, 1999, 2004) and in the references for analytical methods listed in table A1; only brief descriptions are given here. Volatile organic compounds (VOCs) samples were collected in 40-mL sample vials that were purged with three vial volumes of sample water before bottom filling to eliminate atmospheric contamination. Six normal (6-N) hydrochloric acid $(\mathrm{HCl})$ was added as a preservative to the VOC samples. Each sample to be analyzed for perchlorate was collected in a $125-\mathrm{mL}$ polystyrene bottle and then filtered in two or three $20-\mathrm{mL}$ aliquots through a $0.20-\mu \mathrm{m}$ pore-size $\mathrm{CORNING}{ }^{\circledR}$ syringetip disk filter into a sterilized $125-\mathrm{mL}$ bottle. Tritium samples were collected by bottom filling one 1-L polyethylene bottle and one 1-L glass bottle with unfiltered groundwater, after first overfilling the bottles with three volumes of water. Samples for analysis of stable isotopes of hydrogen and oxygen in water were collected in a $60-\mathrm{mL}$ clear glass bottle filled with unfiltered water, sealed with a conical cap, and secured with electrical tape to prevent leakage and evaporation. 
Pesticides and pesticide degradation products, polar pesticides and metabolites, pharmaceutical compounds, and NDMA samples were collected in 1-L baked amber bottles. Pesticide and pharmaceutical samples were filtered through a $0.3-\mu \mathrm{m}$ nominal pore-size glass fiber filter during collection, whereas the NDMA samples were filtered at Weck Laboratories, Inc. prior to analysis. Samples of NDMA were collected in containers treated with 0.05 grams of sodium thiosulfate $\left(\mathrm{Na}_{2} \mathrm{~S}_{2} \mathrm{O}_{3}\right)$.

Groundwater samples for trace elements, major and minor ions, silica, TDS, and alkalinity analyses required filling one $250-\mathrm{mL}$ polyethylene bottle with untreated groundwater, and one $500-\mathrm{mL}$ and one $250-\mathrm{mL}$ polyethylene bottle with filtered groundwater (Wilde and others, 2004). Filtration was done using a $0.45-\mu \mathrm{m}$ pore-size Whatman ${ }^{\odot}$ vented capsule filter. The $250-\mathrm{mL}$ filtered sample then was preserved with $7.5-\mathrm{N}$ nitric acid. Arsenic and iron speciation samples were filtered into a $250-\mathrm{mL}$ polyethylene bottle that was covered with tape to prevent light exposure and preserved with 6-N hydrochloric acid. The nutrient samples were filtered into $125-\mathrm{mL}$ brown polyethylene bottles. Gross alpha and gross beta radiation samples were filtered into 1-L polyethylene bottles and acidified with nitric acid. Carbon isotope samples were filtered and bottom filled into $500-\mathrm{mL}$ glass bottles that first were overfilled with three bottle volumes of groundwater. These samples had no headspace and were sealed with a conical cap to avoid atmospheric contamination. Samples for alkalinity titrations were collected by filtering groundwater into $500-\mathrm{mL}$ polyethylene bottles.

Chromium, radon-222, and noble gases were collected from the hose bib at the well head, regardless of the sampling schedule (fast or slow).

Chromium speciation samples were collected using a $10-\mathrm{mL}$ syringe with an attached $0.45-\mu \mathrm{m}$ pore-size MILLEX ${ }^{\circledR} H A$ disk filter. After the syringe was rinsed thoroughly and filled with groundwater, 4-mL of sample water were forced through the disk filter; the next 2-mL of the groundwater were filtered slowly into a small centrifuge vial for analysis of total chromium. Hexavalent chromium, $\mathrm{Cr}$ (VI), then was collected by attaching a small cation-exchange column to the syringe filter and, after conditioning the column with 2-mL of sample water, an additional 2-mL of sample water were collected in a second centrifuge vial. Both vials were preserved with $10-\mu \mathrm{L}$ of $7.5-\mathrm{N}$ nitric acid (Ball and McClesky, 2003a, b).

For the collection of radon-222, a stainless-steel and Teflon $^{\odot}$ valve assembly was attached to the sampling port at the well head (Wilde and others, 2004). The valve was closed partially to create back pressure, and a $10-\mathrm{mL}$ sample was taken through a Teflon ${ }^{\odot}$ septum on the valve assembly using a glass syringe affixed with a stainless-steel needle. The sample then was injected into a $25-\mathrm{mL}$ vial partially filled with a scintillation mixture (mineral oil) and shaken. The vial then was placed in an insulated cardboard tube to protect the sample during shipping.

Noble gases were collected in $3 / 8$-inch-diameter copper tubes using reinforced nylon tubing connected to the hose bib at the wellhead. Groundwater was flushed through the tubing to dislodge bubbles before flow was restricted with a back pressure valve. Clamps on either side of the copper tube then were tightened, trapping a sample of groundwater for analyses of noble gases (Weiss, 1968).

Alkalinity was measured in the mobile laboratory at the well site on filtered samples by Gran's titration method (Gran, 1952). Titration data were entered directly into PCFF and the concentrations of bicarbonate $\left(\mathrm{HCO}_{3}^{-}\right)$and carbonate $\left(\mathrm{CO}_{3}{ }^{2-}\right)$ automatically were calculated from the titration data using the advanced speciation method. Concentrations of $\mathrm{HCO}_{3}{ }^{-}$and $\mathrm{CO}_{3}{ }^{2-}$ also were calculated from the laboratory alkalinity and $\mathrm{pH}$ measurements. Calculations were made in a spreadsheet using the advanced speciation method (http://or.water.usgs. gov/alk/methods.html) with $\mathrm{pK}_{1}=6.35, \mathrm{pK}_{2}=10.33$, and $\mathrm{pK}_{\mathrm{w}}=14$.

Eight laboratories performed chemical analyses for this study (table A1), although most of the analyses were performed at the NWQL or by labs contracted by the NWQL. The NWQL maintains a rigorous quality-assurance program (Pirkey and Glodt, 1998; Maloney, 2005). Laboratory qualitycontrol samples, including method blanks, continuing calibration verification standards, standard reference samples, reagent spikes, external certified reference materials, and external blind proficiency samples, are analyzed regularly. Method detection limits are tested continuously and laboratory reporting levels are updated accordingly. NWQL maintains National Environmental Laboratory Accreditation Program (NELAP) and other certifications (http://nwql.usgs.gov/ Public/Performance/publiclabcertcoverpage.html). In addition, the Branch of Quality Systems within the USGS Office of Water Quality maintains independent oversight of quality assurance at the NWQL and laboratories contracted by the NWQL. The Branch of Quality Systems also runs the National Field Quality Assurance program that includes annual testing of all USGS field personnel for proficiency in making field water-quality measurements (http://qadata.cr.usgs.gov/nfqa/). Results for analyses made at the NWQL or by laboratories contracted by the NWQL are uploaded directly into NWIS by the NWQL.

Results from the USGS Branch of Quality Systems quality assurance program indicate that boron and iron had negative analytical biases (each of 12 percent), cadmium and uranium had positive analytical biases (of "developing" and 9.7 percent, respectively) during the time period that SCI samples were analyzed at the NWQL (U.S. Geological Survey Branch of Quality Systems, 2008). The results suggest that boron and iron concentrations may be underestimated 
slightly and cadmium and uranium concentrations may be overestimated slightly.

\section{Data Reporting}

The following section details the laboratory-reporting conventions and the constituents that are determined by multiple methods or by multiple laboratories.

\section{Reporting Limits}

The USGS NWQL uses the laboratory reporting level (LRL) as a threshold for reporting analytical results. The LRL is set to minimize the reporting of false negatives (not detecting a compound when it actually is present in a sample) to less than 1 percent (Childress and others, 1999). The LRL usually is set at two times the long-term method detection level (LT-MDL). The LT-MDL is derived from the standard deviation of at least $24 \mathrm{MDL}$ determinations made over an extended period of time. LT-MDLs are monitored and updated continually. The method detection limit (MDL) is the minimum concentration of a substance that can be measured and reported with 99-percent confidence that the concentration is greater than zero (at the MDL there is less than 1 percent chance of a false positive) (Childress and others, 1999; U.S. Environmental Protection Agency, 2002). The USGS NWQL updates LRL values regularly and the values listed in this report were in effect during the period when analyses were made for groundwater samples from the SCI study (August to December 2008).

Detections between the LRL and the LT-MDL are reported as "estimated" concentrations (designated with an "E" before the values in the tables and text). For informationrich methods, detections below the LT-MDL have high certainty of detection, but the precise concentration is uncertain. Information-rich methods are those that utilize gas chromatography or high-performance liquid chromatography (HPLC) with mass spectrometry detection (VOCs, pesticides, and polar pesticides). Compounds are identified by presence of characteristic fragmentation patterns in their mass spectra in addition to being quantified by measurement of peak areas at their associated chromatographic retention times. E-coded values also may result from detections outside the range of calibration standards, for detections that did not meet all laboratory quality-control criteria, and for samples that were diluted prior to analysis (Childress and others, 1999).

Some constituents in this study are reported using minimum reporting levels (MRLs) or method uncertainties (MU). The MRL is the smallest measurable concentration of a constituent that may be reliably reported using a given analytical method (Timme, 1995). The method uncertainty generally indicates the precision of a particular analytical measurement; it gives a range of values wherein the true value will be found.

Results for most constituents are presented using the LRL or MRL values provided by the analyzing laboratories. Results for some constituents are presented using raised study reporting limits (SRLs) derived from assessment of data from quality-control samples associated with groundwater samples collected as part of the GAMA Priority Basins Project. The SRLs were determined by statistical assessment of results from the field blanks collected during the first 21 GAMA Priority Basins Project study units (May 2004 through January 2008) (L.D. Olsen and M.S. Fram, U.S. Geological Survey, written commun., 2009). The statistical analysis used order statistical and binomial probabilities to construct an upper confidence limit for the amount of contamination potentially present in field blanks, and by inference, in groundwater samples (Hahn and Meeker, 1991). The upper confidence limit is the maximum concentration of a constituent for which there is a 90-percent confidence level that no more than 10 percent of the groundwater samples might have a higher concentration of that constituent due solely to contamination of the groundwater sample during sample collection, handling, and analysis. This maximum concentration corresponds to the concentration in the field blank that is at the $95^{\text {th }}$ percentile of the 86 field blanks used in the statistical assessment. For most constituents, this maximum concentration was below the LRL or MRL for the constituent. Data for such constituents are reported with the LRL or MRL. For some constituents, this maximum concentration was greater than the LRL or MRL. An SRL then was defined as equal to the concentration in the $95^{\text {th }}$ percentile field blank. Detections of those constituents reported by the laboratory with concentrations greater than the LRL or MRL but less than the SRL are considered nondetections in this report and are reported in table 8 with a "less-than-or-equalto" $(\leq)$ sign preceding the reported value.

The methods used for analysis of radiochemical constituents (gross alpha radioactivity and gross beta radioactivity) measure activities by counting techniques (table A1). The reporting limits for radiochemical constituents are based on sample-specific critical levels $\left(\mathrm{ssL}_{\mathrm{C}}\right)$ (McCurdy and others, 2008). The critical level is analogous to the LT-MDL used for reporting analytical results for organic and nonradioactive inorganic constituents. Here, the critical level is defined as the minimum measured activity that indicates a positive detection of the radionuclide in the sample with less than a 5-percent probability of a false positive detection. Sample-specific critical levels are used for radiochemical measurements because the critical level is sensitive to sample size and sample yield during analytical processing, as well as being dependent on instrument background, counting times for the sample and background, and the characteristics of the instrument being used and the nuclide being measured. $\mathrm{An} \mathrm{ssL}_{\mathrm{C}}$ is calculated for each sample, and the measured activity in the sample is 
compared to the $\mathrm{ssL}_{\mathrm{C}}$ associated with that sample. Measured activities less than the $\mathrm{ssL}_{\mathrm{C}}$ are reported as nondetections (table 13A).

The analytical uncertainties associated with measurement of activities also are sensitive to sample-specific parameters, including sample size, sample yield during analytical processing, time elapsed between sample collection and various steps in the analytical procedure, as well as parameters associated with the instrumentation. Therefore, measured activities of radioactive constituents are reported with sample-specific combined standard uncertainties (CSU) (table 13A). Specifically, activities of gross alpha and gross beta radiation are reported with sample-specific CSU. The CSU is reported at the 68-percent confidence level (1-sigma). Radon activities are measured by a different laboratory than the other radioactive constituents, and the laboratory reports results with 2-sigma (95-percent confidence level) standard combined uncertainties (table 13B).

\section{Notation}

Stable isotopic compositions of oxygen, hydrogen, and carbon are reported as relative isotope ratios in units of per mil using the standard delta notation (Coplen and others, 2002):

$$
\delta^{i} E=\left[\frac{R_{\text {sample }}}{R_{\text {reference }}}-1\right] \cdot 1,000 \text { per mil }
$$

$$
\begin{aligned}
& \text { where } \\
& i \quad \text { is the atomic mass of the heavier isotope of } \\
& E \quad \text { is the element ( } \mathrm{O} \text { for oxygen, } \mathrm{C} \text { for carbon, } \\
& \text { or } \mathrm{H} \text { for hydrogen); } \\
& R_{\text {sample }} \text { is the ratio of the abundance of the heavier } \\
& \text { isotope of the element }\left({ }^{18} \mathrm{O},{ }^{13} \mathrm{C} \text {, or }{ }^{2} \mathrm{H}\right) \text { to } \\
& \text { the lighter isotope of the element, } \\
& \left({ }^{16} \mathrm{O},{ }^{12} \mathrm{C} \text {, or }{ }^{1} \mathrm{H}\right) \text { in the sample; and, } \\
& R_{\text {reference }} \text { is the ratio of the abundance of the heavier } \\
& \text { isotope of the element to the lighter isotope } \\
& \text { of the element in the reference material. }
\end{aligned}
$$

The reference material for oxygen and hydrogen is Vienna Standard Mean Ocean Water (VSMOW), which is assigned $\delta^{18} \mathrm{O}$ and $\delta^{2} \mathrm{H}$ values of zero per mil (note than $\delta^{2} \mathrm{H}$ is sometimes written as $\delta \mathrm{D}$ because the common name of the heavier isotope of hydrogen, hydrogen-2, is deuterium). The reference material for carbon is Vienna Pee Dee Belemnite (VPDB), which is assigned a $\delta^{13} \mathrm{C}$ value of zero per mil. Positive values indicate enrichment of the heavier isotope and negative values indicate depletion of the heavier isotope, compared to the ratios observed in the standard reference material.

\section{Constituents on Multiple Analytical Schedules}

Eleven constituents targeted in this study were measured by more than one analytical schedule or by more than one laboratory (table A2). The preferred methods for these constituents were selected on the basis of the procedure recommended by the NWQL. Methods with full approval are preferred over those with provisional approval and approved methods are favored over research methods. The method with greater accuracy and precision and lower LRLs for the overlapping constituents generally is preferred. However, the method with higher LRLs may be selected as the preferred method to provide consistency with historical data analyzed by the same method.

Some of the water-quality indicators (field parameters) $\mathrm{pH}$, specific conductance, and alkalinity-were measured in the field and at the NWQL. The field measurements are the preferred method for all three constituents $(\mathrm{pH}$, specific conductance, and alkalinity) because groundwater samples change once they are removed from the ambient environment; however, both measurements are reported.

Tritium also is measured at two laboratories: Lawrence Livermore National Laboratory (LLNL) and U.S. Geological Survey Stable Isotope and Tritium Laboratory (SITL), although only a limited amount of tritium data from the SITL were available for reporting at the time of this publication.

For arsenic, chromium, and iron concentrations, the approved method, Schedule 1948 used by the NWQL, is preferred over the research methods used by the USGS Trace Metal Laboratory. The concentrations measured by the Trace Metal Laboratory only are used to calculate ratios of redox

species for each element, $\frac{\mathrm{As}(\mathrm{V})}{\mathrm{As}(\mathrm{III})}$ for arsenic, $\frac{\mathrm{Cr}(\mathrm{VI})}{\mathrm{Cr}(\mathrm{III})}$ for chromium, and $\frac{\mathrm{Fe}(\mathrm{III})}{\mathrm{Fe}(\mathrm{II})}$ for iron. For example:

$$
\frac{\mathrm{Fe}(\mathrm{III})}{\mathrm{Fe}(\mathrm{II})}=\frac{\mathrm{Fe}(\mathrm{T})-\mathrm{Fe}(\mathrm{II})}{\mathrm{Fe}(\mathrm{II})}
$$

where

$\mathrm{Fe}(\mathrm{T})$ is the total iron concentration (measured),

$\mathrm{Fe}$ (II) is the concentration of ferrous iron (measured), and $\mathrm{Fe}(\mathrm{III})$ is the concentration of ferric iron (calculated). 


\section{Quality Assurance}

The purpose of quality assurance is to identify which data best represent environmental conditions and which may have been affected by contamination or bias during sample collection, processing, storage, transportation, or laboratory analysis. Four types of quality-control (QC) tests were used in this study: blank samples were collected to assess positive bias due to contamination during sample handling or analysis; replicate samples were collected to assess variability; matrix spike tests were done to assess positive or negative bias; and surrogate compounds were added to samples analyzed for organic constituents to assess bias of laboratory analytical methods. In this report, detections of organic constituents in groundwater samples that may have resulted from contamination were flagged with a "V" remark code, and were not considered detections for calculations of detection frequencies in water-quality assessments. Detections of inorganic constituents in groundwater samples that may have resulted from contamination during sample handling or analysis were flagged with a " $\leq$ " remark code to indicate that the amount of potential contamination may have been sufficient to change a nondetection into a detection, relative to the stated reporting level. Because of the potential contamination, the actual concentration in the groundwater sample may be less than or equal to $(\leq)$ the measured concentration. The evaluation of QC data presented in this report was based on results for QC samples collected for the SCI study unit and on results for QC samples for the 21 GAMA Priority Basins Project study units sampled from May 2004 through January 2008.

The quality-assurance protocols used for this study followed the protocols used by the USGS NAWQA program (Koterba and others, 1995) and described in the USGS National Field Manual (U.S. Geological Survey, variously dated). The quality assurance plan followed by the NWQL, the primary laboratory used to analyze samples for this study, is described in Maloney (2005) and Pirkey and Glodt (1998).

\section{Blanks}

The primary purposes of collecting blanks are to evaluate the magnitude of potential contamination of samples by analytes of interest during sample collection, handling, or analysis, and to identify and mitigate sources of this contamination.

\section{Blank Collection and Analysis}

Blanks were collected using blank water certified by the NWQL to contain less than the LRL or MRL of the analytes investigated in the study (http://wwwnwql.cr.usgs.gov/USGS/ $O B W / o b w . h t m l)$. Nitrogen-purged, organic-free blank water was used for field blanks of organic constituents, and inorganic-free blank water was used for field blanks of other constituents. For SCI, field blanks were collected at 11 percent of the wells sampled. Field blanks were analyzed for VOCs; pesticides and pesticide degradates; polar pesticides and metabolites; pharmaceuticals; perchlorate; NDMA; trace elements; nutrients; major and minor ions; silica; TDS; arsenic, chromium, and iron speciation; and radioactive constituents. Field blanks were not collected for tritium or noble gases. Tritium and noble gases are in the atmosphere and would dissolve into any solution used in collecting a blank, making it impractical to collect a field blank for these analytes. Stable-isotopic ratios of oxygen, hydrogen, and carbon are an intrinsic property of any of these elements; therefore, the concept of a blank does not apply to these ratios.

To collect field blanks, blank water either was pumped or poured through the sampling equipment (fittings and tubing) used to collect groundwater, then processed and transported using the same protocols used for the groundwater samples. Eight to 12-L of blank water were pumped or poured through the sampling equipment before each field blank was collected.

\section{Assessment of Blank Results}

Contamination in blanks may originate from several different types of sources that require different strategies for assessment of potential contamination of groundwater samples during sample collection, handling, and analysis. Four primary modes of contamination are assessed in the event of detections in field-blanks or atypical results in groundwater samples: (1) impurities in the water used to collect the blanks, (2) contamination during sample collection and handling from a known source or condition present at the field site, (3) carry-over of material on the sampling equipment from one sample to the next sample, and (4) systematic and random contamination from field and laboratory equipment and processes. The fourth source of contamination (systematic and random) is being addressed using a larger set of field blank results from multiple studies, in addition to the results from field blanks collected during SCI. The development of this approach and its methods are described by L.D. Olsen and M.S. Fram (U.S. Geological Survey, written commun., 2009).

The first potential mode evaluated is the presence of impurities in the water used to collect the field blank. Because the blanks were collected using blank water certified by the NWQL to contain less than the LRL or MRL of the analytes investigated in the study, the blank water itself is very rarely the source of constituents detected in field blanks. However, blank water sometimes is used before the certification process has been completed, thus, the certificates of analysis always must be checked. Blank water used in the GAMA SCI study unit was certified by the NWQL prior to field blank collection. 
The second potential mode evaluated is contamination from identifiable, known sources present at a specific field site. Contamination from specific sources may produce distinctive patterns of detections in field blanks and groundwater samples, particularly for the VOCs. Substances that may be encountered at the field site, such as cements used on PVC-piping, contain recognizable associations of VOC constituents. For example, cements used on PVC-piping primarily are composed of tetrahydrofuran with lesser amounts of acetone and methyl ethyl ketone (2-butanone). However, detection of these recognizable associations of VOC constituents in groundwater samples does not necessarily indicate contamination during sample collection, because these VOC constituents also may occur together in groundwater.

If a recognizable association of VOC constituents was detected in a field blank or in a groundwater sample, then the field notes and photographs from the site at which the sample was collected were examined for presence of conditions that may have resulted in contamination of the field blank or groundwater sample during sample collection. If the constituents were present in the field blank and groundwater sample from the same site at similar concentrations and the field notes or photographs indicated that the probable contaminant source was present, then the detections of those constituents in the groundwater sample were V-coded, and all other groundwater samples collected at sites where the same condition may have occurred were considered for V-coding. If the constituents were present in a groundwater sample and not the associated field blank, or a groundwater sample from a site where no blanks were collected, and the field notes or photographs indicated that the presence of conditions that may have resulted in contamination of the groundwater sample during sample collection, the data were considered for V-coding. If no conditions that may have resulted in contamination of the groundwater sample during sample collection were identified in the field notes or photographs, then V-codes were not applied.

The third potential mode of contamination that was evaluated was carry-over from the previous groundwater sample or field blank collected with the same equipment. Carry-over between samples is very rare because the procedures used to clean the equipment between samples have been developed and extensively tested to assure that carry-over is mitigated as much as possible. Potential carry-over was evaluated using time-series analysis to look for patterns suggestive of carryover of constituents from a sample with high concentrations to the next groundwater sample or field blank collected with the same equipment. If nondetections were reported in field blanks or groundwater samples collected after the collection of groundwater samples containing high concentrations of the constituent, then carry-over as a mode of contamination was ruled out.

The fourth potential mode of contamination that was evaluated was random or systematic contamination from field or laboratory equipment or processes. All detections in field blanks that could not be accounted for by impurities in the source-solution water, specific known conditions at field sites, or carry-over between samples were evaluated for random contamination. Random contamination in field and laboratory processes has an equal chance of affecting each groundwater sample, thus, strategies for flagging detections of constituents that are subject to random contamination in field and laboratory processes must be applied to all groundwater samples.

Different notation was used for flagging detections of organic and inorganic constituents that may have been subjected to contamination during sample collection, handling, and analysis. Inorganic constituents naturally are present in groundwater, and the concerns about inorganic constituents generally are related to concentration, rather than to detection (presence or absence). In contrast, concerns about organic constituents generally are related to both detection and concentration. Therefore, different schema are used for assessing and flagging data for organic and inorganic constituents.

For organic constituents, V-codes were applied. The purpose of V-coding was to flag detections that have a greater chance of being false-positive detections. A false-positive detection is a detection that is caused by contamination during sample collection, handling, and analysis of a groundwater sample that would otherwise have a nondetection for that constituent. Results with V-codes were not considered detections of the constituent for this study and were not included in calculations of detection frequencies for organic constituents.

The V-coding level was defined as the highest concentration of the constituent detected in a field blank plus the LT-MDL (equal to one-half the LRL) for that constituent. Detections of the constituent in groundwater samples at concentrations less than this V-coding level were flagged with a "V" in front of the reported value in the data tables. The highest concentration measured in a blank was assumed to represent the highest potential amount of contamination. Thus, the V-code flags the results that could have changed from nondetection to a detection, relative to the LT-MDL, due to contamination. Results with V-codes were not considered detections of the constituent for this study and were not included in calculations of detection frequencies for organic constituents.

For inorganic constituents, a " $\leq$ " symbol was used to identify low-concentration detections of constituents that may have been affected by contamination. The $\leq$ symbol signifies that the concentration of the constituent in the groundwater sample is less than or equal to the measured concentration (including the possibility that it may be less than the LT-MDL and, therefore, a nondetection). For select trace elements (aluminum, chromium, copper, lead, manganese, nickel, tungsten, vanadium, and zinc), the concentration cutoff, hereafter referred to as the study reporting limit, SRL, for applying the $\leq$ symbol was determined from a statistical assessment of results for 86 field blanks collected between May 2004 and January 2008 . The concentration threshold for applying the $\leq$ symbol was equal to the concentration of the field blank ranked at the 90-percent confidence level for the $90^{\text {th }}$ percentile of the binomial distribution of the 86 field blanks (L.D. Olsen and M.S. Fram, U.S. Geological Survey, written commun., 2009). 
For all other inorganic constituents, the SRL for applying the $\leq$ symbol was determined from assessment of the field blanks collected at SCI sites only, and was defined as equal to the highest concentration measured in the six field blanks collected at SCI sites (field blanks were collected at 11 percent of the wells sampled). In the data tables, a $\leq$ symbol was put in front of measured values that were less than the threshold concentration. Future reports in this series will use the approach of L.D. Olsen and M.S. Fram (U.S. Geological Survey, written commun., 2009) for all inorganic constituents.

\section{Replicates}

Sequential replicate samples were collected to assess the precision of the water-quality data. Estimates of data precision are needed to assess whether differences between concentrations in samples are due to differences in groundwater quality or to variability that may result from collecting, processing, and analyzing the samples.

Two methods for measuring variability were needed to adequately assess precision over the broad range of measured concentrations of most constituents. The variability between measured concentrations in the pairs of sequential replicate samples was represented by the standard deviation (SD) for low concentrations and by relative standard deviation (RSD) for high concentrations (Anderson, 1987; Mueller and Titus, 2005). The RSD is defined as the SD divided by the mean concentration for each replicate pair of samples, expressed as a percentage. The boundary between concentrations for which variability is assessed with SD and concentrations for which variability is assessed with RSD was defined as five times the LRL for each constituent.

For this study, acceptable precision for replicate sample pairs is defined as follows:

- For concentrations less than five times the LRL $(<5 \mathrm{LRL})$, an SD of less than one-half LRL is acceptable.

- For concentrations greater than (or equal to) five times the LRL ( $\leq 5 \mathrm{LRL}$ ), an RSD of less than 10 percent is acceptable. For comparison, an RSD of 10 percent is equivalent to a relative percent difference (RPD) of 14 percent.

- For activities of radiochemical constituents, the presence of overlap between the results (value \pm 1 -sigma $\mathrm{CSU})$ is acceptable.

If results from replicate sample pairs indicate that precision is unacceptable for a constituent, and no specific reason can be identified, this greater variability must be considered when the data are used for the purposes of comparison. If measured concentrations are slightly above a water-quality threshold, then actual concentrations could be slightly below that threshold. Similarly, if measured concentrations are slightly below a water-quality threshold, then actual concentrations could be slightly above. Also, if a constituent has high variability in replicate sample pairs, a larger difference between concentrations measured in two samples is required to conclude that the two samples have significantly different concentrations.

For organic and inorganic constituents (except for radiochemical constituents), if both values for a replicate sample pair were reported as detections, the SD was calculated if the mean concentration was $<5 \mathrm{LRL}$ for the constituent or the RSD was calculated if the mean concentration was $\geq 5$ LRL for the constituent. If both values were reported as nondetects, the variability was set to zero by definition. Cases other than two detections or two nondetects were treated as follows:

- For organic constituents, if one or both values were assigned a V-code, neither SD nor RSD was calculated. A V-code indicates that the constituent was detected in blanks and was excluded from the dataset of groundwater-quality results. The data might not represent the concentration of the constituent in the groundwater sample.

- For organic and inorganic constituents, if one value was reported as a nondetect, and the other value was reported as a detection below the LRL, a value of zero was substituted for the nondetect and the SD calculated. Substituting zero for the nondetect yields the maximum estimate of variability for the replicate pair.

- For inorganic constituents, if one value for a sample pair was reported as a nondetect and the other value was reported as a $\leq$-coded value less than the $\mathrm{SRL}$, or if both values were reported as $\leq$-coded values less than the SRL, neither SD nor RSD was calculated because the values may be analytically identical. The $\leq$-code indicates that the value is a maximum potential concentration and that the concentration may be low enough to be reported as a nondetect.

- For organic and inorganic constituents, if one value was reported as a nondetect and the other value was reported as a detection greater than the LRL, the variability for the pair was considered unacceptable. 


\section{Matrix Spikes}

Addition of a known concentration of a constituent ('spike') to a replicate environmental sample enables the analyzing laboratory to determine the effect of the matrix, in this case groundwater, on the analytical technique used to measure the constituent. The known compounds added in matrix spikes are the same as those being analyzed in the method. This enables an analysis of matrix interferences on a compound-by-compound basis. For this study, matrix spikes were added by the laboratory performing the analysis. Low matrix-spike recovery may indicate that the compound might not be detected in some samples if it were present at very low concentrations. Low and high matrix-spike recoveries may be a potential concern if the concentration of a compound in a groundwater sample is close to the MCL: a low recovery could result in a falsely measured concentration below the MCL, whereas, a high recovery could result in a falsely measured concentration above the MCL.

The GAMA Priority Basins Project defined the dataquality objective for acceptable matrix spike recoveries as 70 to 130 percent. Only constituents with matrix spike recoveries outside of this range were flagged as having unacceptable recoveries, they were in tables $3 B$ and $3 C$. For many constituents, an acceptable range of 70 to 130 percent for matrix spike recovery was more restrictive than the acceptable control limits for laboratory "set" spike recoveries. Laboratory set spikes are aliquots of laboratory blank water to which the same spike solution used for the matrix spikes has been added. One set spike is analyzed with each set of samples. Acceptable control limits for set spikes are defined, relative to the long-term variability in recovery. For example, for many NWQL schedules, acceptable set spike recovery is within \pm 3 F-pseudosigma of the median recovery for at least 30 set spikes (Conner and others, 1998). Matrix spikes were performed for VOCs, pesticides and pesticide degradates, polar pesticides and metabolites, pharmaceuticals, perchlorate, and NDMA because the analytical methods for these constituents are chromatographic and may be susceptible to matrix interferences. Replicate samples for matrix-spike additions were collected at approximately 6 percent of the wells sampled, although not all analyte classes were tested at every well (tables $A 5 A-A 5 D$ ).

\section{Surrogates}

Surrogate compounds are added to environmental samples in the laboratory prior to analysis to evaluate the recovery of similar constituents. Surrogate compounds were added to all groundwater and quality-control samples that were analyzed for VOCs and pesticides (table A6). Most of the surrogate compounds are deuterated analogs of compounds being analyzed. For example, the surrogate toluene- $d 8$ that is used for the VOC analytical method has the same chemical structure as toluene, except that the eight hydrogen-1 atoms on the molecule have been replaced by deuterium (hydrogen-2). Toluene- $d 8$ and toluene behave very similarly in the analytical procedure, but the small mass difference between the two results in slightly different chromatographic retention times, thus, the use of a toluene- $d 8$ surrogate does not interfere with the analysis of toluene (Grob, 1995). Only 0.015 percent of hydrogen atoms are deuterium (Firestone and others, 1996), thus, deuterated compounds like toluene- $d 8$ do not occur naturally and are not found in environmental samples. Surrogates are used to identify general problems that may arise during sample analysis that could affect the analysis results for all compounds in that sample. Potential problems include matrix interferences (such as high levels of dissolved organic carbon) that produce a positive bias, or incomplete laboratory recovery (possibly due to improper maintenance and calibration of analytical equipment) that produces a negative bias. A 70- to 130 -percent recovery of surrogates generally is considered acceptable; values outside this range indicate possible problems with the processing and analysis of samples (Connor and others, 1998; Sandstrom and others, 2001).

\section{Quality-Control Results}

\section{Detections in Field Blanks}

Field blanks were collected at 11 percent of the sites sampled in SCI. Table A3 presents a summary of detections in field blanks. Chloroform (trichloromethane) was the only VOC detected in the field blank that also was detected in groundwater samples. This blank detection was considered to be random contamination, which has an equal chance of affecting each groundwater sample. Therefore, strategies for flagging detections of constituents that are subject to random contamination must be applied to all groundwater samples. Due to the detection of chloroform in the field blank, all chloroform detections were subject to a V-coding level of $0.04 \mu \mathrm{g} / \mathrm{L}(\mathrm{E} 0.02 \mu \mathrm{g} / \mathrm{L}$ plus one-half the LRL of $0.04 \mu \mathrm{g} / \mathrm{L}$ ). Chloroform was detected at concentrations equal to or below the V-coding level in four groundwater samples and all of these detections were $\mathrm{V}$-coded as nondetections (tables 5 and $A 3$ ).

Field blanks for pesticides and pesticide degradates were collected at 6 of the 54 SCI wells sampled. The only pesticide or pesticide degradate detected in a field blank was one detection of atrazine. This blank detection also was considered to be random contamination and, as a result, all atrazine detections in SCI were subject to a V-coding level of $0.0115 \mu \mathrm{g} / \mathrm{L}$ $(\mathrm{E} 0.008 \mu \mathrm{g} / \mathrm{L}$ plus one-half the LRL of $0.007 \mu \mathrm{g} / \mathrm{L})$. Atrazine was detected at concentrations below the V-coding level in three groundwater samples and all of these detections were $\mathrm{V}$-coded as nondetections (tables $6 \mathrm{~A}$ and $A 3$ ). 
Trace-element data were assessed for potential flagging of results using the GAMA study reporting limits (SRLs), which are based on results for 86 field blanks collected between May 2004 and January 2008, in conjunction with the six field blanks collected at SCI sites. Aluminum, chromium, copper, lead, manganese, nickel, tungsten, vanadium, and zinc have SRLs previously determined by the field blank study (Appendix: Assessment of Blank Results). Measured values that are less than the SRL are flagged with a $\leq$ symbol in table 8. Field blanks were collected at 6 of the 54 sites in SCI sampled for analysis of trace elements. Four trace elements were detected in one field blank; chromium $(0.15 \mu \mathrm{g} / \mathrm{L})$, cop$\operatorname{per}(1.28 \mu \mathrm{g} / \mathrm{L})$, nickel $(\mathrm{E} 0.12 \mu \mathrm{g} / \mathrm{L})$, and zinc $(\mathrm{E} 1.25 \mu \mathrm{g} / \mathrm{L})$. All measured detections of these trace metals less than their SRL levels were flagged with a $\leq$ symbol (tables 8 and A3). There were no other trace metals detected in any of the six field blanks in SCI.

Field blanks were collected at 6 of the 54 sites sampled for analysis of major and minor ions, silica, and TDS. Silica was detected in one field blank, resulting in a study reporting limit (SRL) at E0.015 mg/L. This blank detection was considered to be random contamination, which has an equal chance of affecting each groundwater sample, thus, all groundwater samples below the SRL value were subject to flagging. No groundwater samples had silica concentrations measured below E0.015 mg/L, therefore, no values were flagged with a $\leq$ symbol (table 10).

Two field blanks were collected for analysis of radioactive constituents. Gross alpha radioactivity (72-hour count) was measured with an activity of $0.19 \pm 0.15 \mathrm{pCi} / \mathrm{L}$ in one field blank. None of the environmental gross alpha radioactivity samples had measured activities less than $0.34 \mathrm{pCi} / \mathrm{L}$, the upper confidence limit of the maximum activity measured in the blank, therefore, no environmental values were flagged with a $\leq$ symbol as a result of the blank detection (table 13A).

No constituents were detected in the field blanks for the following analyte groups: polar pesticides and metabolites (two field blanks), perchlorate (six field blanks), NDMA (two field blanks), nutrients (six field blanks), arsenic, chromium, and iron species analyzed at the USGS Trace Metal Laboratory (one field blank), gross alpha radioactivity (30-day count) and gross beta radioactivity (72-hour and 30-day counts) (two field blanks).

\section{Variability in Replicate Samples}

Tables $A 4 A$ and $A 4 B$ summarize the results of replicate analyses for constituents detected in groundwater samples collected in the SCI study. Of the 379 replicate pairs of constituents analyzed, 63 were for constituents detected in at least one groundwater sample. Of these 63 pairs, 1 pair (perchlorate) had a result outside the limits for acceptable precision. Results for replicate analyses for constituents that were not detected are not reported in tables $A 4 A$ and $A 4 B$.

The replicate pair for perchlorate had a RSD value of 88 percent, well above the unacceptable 10 percent threshold.
However, the environmental sample concentration was less than one-third and the replicate sample concentration was one-twentieth of the concentration of the corresponding MCLCA (tables $3 E$ and 7). The less-than-acceptable precision for this constituent at these low concentrations will not affect the assessments of groundwater quality being made by the GAMA Priority Basins Project.

Two replicate pairs for the 85 VOCs and the 63 pesticide and pesticide degradate compounds were all reported as nondetections, while replicate pairs for polar pesticides and metabolites were not collected in the SCI study unit.

Two replicate pairs of samples were analyzed for trace elements, nutrients, major and minor ions, silica, total dissolved solids (TDS), isotopic tracers, and carbon-14 activities. One replicate pair was analyzed for tritium activities. All of the replicate pairs had SD or RSD values within the acceptable range of less than 10 percent (table $A 4 B$ ).

No environmental detections were affected as a result of the replicate analysis.

\section{Matrix-Spike Recoveries}

Tables $A 5 A-D$ presents a summary of matrix-spike recoveries for the SCI study. The addition of a spike or known concentration of a constituent to an environmental sample enables the analyzing laboratory to determine the effect of the matrix, in this case groundwater, on the analytical technique used to measure the constituent. Three environmental samples were spiked with VOCs to calculate matrix-spike recoveries (table A5A). All of the $85 \mathrm{VOC}$ spike compounds had median matrix-spike recoveries within the acceptable range of 70 to 130 percent. Three VOC spike compounds; 3-chloropropene, diethyl ether, and iodomethane (methyl iodide) had one matrix-spike recovery greater than 130 percent, however, they were not detected in groundwater samples. One VOC spike compound (dichlorodifluoromethane (CFC-12) had one matrix-spike recovery below 70 percent, and it was detected in three groundwater samples (two grid and one understanding wells) (tables $3 A$ and 5). [NOTE - low recoveries may indicate that the compound might not have been detected in some samples if it was present at very low concentrations].

Three groundwater samples were spiked with pesticide and pesticide degradate compounds to calculate matrix-spike recoveries. Thirty-three of the 63 spike compounds had median matrix-spike recoveries within the acceptable range of 70 to 130 percent (table A5B). Three of the four compounds detected in groundwater samples had median matrix-spike recoveries within the acceptable range. Median spike-matrix recovery for deethylatrazine (2-Chloro-4-isopropylamino-6amino-s-triazine) was below the acceptable range (62 percent). No pesticide and pesticide degradate spike compounds had recoveries greater than 130 percent. Thirty-nine pesticide and pesticide degradate spike compounds had at least one recovery below 70 percent. Of these compounds, deethylatrazine (2-chloro-4-isopropylamino-6-amino-s-triazine) and prometon were the only compounds also detected in groundwater 
samples (tables $3 B$ and $6 A$ ). The deethylatrazine (2-chloro4-isopropylamino-6-amino-s-triazine) detections occurred in three grid and two understanding wells, and prometon in two grid wells. None of the groundwater samples with environmental detections and unacceptable recoveries in matrix spikes analyzed at the NWQL were in the same batch. Thus, none of the pesticide and pesticide degradate environmental detections were flagged (table 6A). [NOTE - low recoveries indicate that the compound might not have been detected in some samples if it was present at very low concentrations].

One groundwater sample was spiked with polar pesticide and metabolite compounds to calculate matrix-spike recoveries. Forty-two of the 60 spike compounds had matrix-spike recoveries within the acceptable range of 70 to 130 percent (table A5C). Bentazon, the only polar pesticide and metabolite compound detected in groundwater samples had a matrixspike recovery within the acceptable range (76 percent). Ten polar pesticide and metabolite compounds had matrix-spike recoveries below 70 percent, while eight polar pesticide and metabolite compounds had recoveries above 130 percent (table A5C). [NOTE - low recoveries indicate that the compound might not have been detected in some samples if it was present at very low concentrations].

Four groundwater samples were spiked with perchlorate and one with NDMA at Weck Laboratories, Inc. For perchlorate, the median matrix-spike was used and for NDMA the median matrix-spike was represented by the recovery from the single spike sample. All spike recoveries were within the acceptable range of 70 to 130 percent (table A5D).

\section{Surrogate Compound Recoveries}

Surrogate compounds were added to environmental samples in the laboratory and analyzed to evaluate the recovery of similar constituents. Table A6 lists the surrogate, analytical schedule on which it was applied, the number of analyses for blank and environmental samples, the number of surrogate recoveries below 70 percent, and the number of surrogate recoveries above 130 percent for the blank and groundwater samples. Blank and environmental samples were considered separately to assess whether the matrices present in groundwater samples affect surrogate recoveries.

In SCI, most surrogate recoveries were within acceptable range of 70 to 130 percent recovery. In total, 85 percent of the surrogate recoveries for VOC, 88 percent of the surrogate recoveries for pesticide, and 85 percent of the surrogate recoveries for polar pesticide analyses were within the acceptable range. 
Table A1. Analytical methods used for the determination of organic and inorganic constituents by the U.S. Geological Survey (USGS) National Water Quality Laboratory (NWOL) and additional contract laboratories.

[Laboratory entity codes in the U.S. Geological Survey (USGS) National Water Information System (NWIS) for laboratories other than the USGS National Water Quality Laboratory (NWQL) are given in parentheses after the laboratory names. Abbreviations: UV, ultraviolet; VOCs, volatile organic compounds]

\begin{tabular}{|c|c|c|c|}
\hline Analyte & $\begin{array}{l}\text { Analytical } \\
\text { method }\end{array}$ & $\begin{array}{l}\text { Laboratory and } \\
\text { analytical schedule }\end{array}$ & Citation(s) \\
\hline \multicolumn{4}{|c|}{ Water-quality indicators } \\
\hline \multicolumn{4}{|c|}{ Organic constituents } \\
\hline $\begin{array}{l}\text { Pesticides and } \\
\text { degradates }\end{array}$ & $\begin{array}{l}\text { Solid-phase extraction and gas } \\
\text { chromatography/mass spectrometry }\end{array}$ & NWQL, Schedule 2003 & $\begin{array}{l}\text { Zaugg and others, 1995; Lindley and } \\
\text { others, 1996; Madsen and others, 2003; } \\
\text { Sandstrom and others, } 2001\end{array}$ \\
\hline $\begin{array}{l}\text { Polar pesticides and } \\
\text { metabolites }\end{array}$ & $\begin{array}{l}\text { Solid-phase extraction and high } \\
\text { performance liquid chromatography } \\
\text { (HPLC)/mass spectrometry with } \\
\text { selective-ion monitoring }\end{array}$ & NWQL, Schedule 2060 & Furlong and others, 2001 \\
\hline \multicolumn{4}{|c|}{ Constituents of special interest } \\
\hline Perchlorate & $\begin{array}{l}\text { Liquid chromatography with mass } \\
\text { spectrometry/mass spectrometry } \\
\text { (USEPA Method } 331.0 \text { ) }\end{array}$ & $\begin{array}{l}\text { Weck Laboratories, Inc., } \\
\text { standard operating } \\
\text { procedure ORG099.R01 }\end{array}$ & $\begin{array}{l}\text { U.S. Environmental Protection Agency, } \\
2005\end{array}$ \\
\hline $\begin{array}{l}N \text {-nitrosodimethylamine } \\
\quad \text { (NDMA) }\end{array}$ & $\begin{array}{l}\text { Isotopic dilution with gas } \\
\text { chromatography and chemical- } \\
\text { ionization mass spectrometry } \\
\text { (USEPA Method } 1625 \text { modified) }\end{array}$ & $\begin{array}{l}\text { Weck Laboratories, Inc., } \\
\text { standard operating } \\
\text { procedure ORG065.R10 }\end{array}$ & $\begin{array}{l}\text { U.S. Environmental Protection Agency, } \\
\text { 1989; Plomley and others, } 1994\end{array}$ \\
\hline $\begin{array}{l}\text { Arsenic, chromium, and } \\
\text { iron speciation }\end{array}$ & $\begin{array}{l}\text { Various techniques of ultraviolet } \\
\text { visible (UV-VIS) spectrophotometry } \\
\text { and atomicabsorbance spectroscopy }\end{array}$ & $\begin{array}{l}\text { USGS Trace Metal } \\
\text { Laboratory, Boulder, } \\
\text { Colorado (USGSTMCO) }\end{array}$ & $\begin{array}{l}\text { Stookey, 1970; To and others, 1998; Ball } \\
\text { and McCleskey, 2003a and 2003b; } \\
\text { McCleskey and others, } 2003\end{array}$ \\
\hline
\end{tabular}


Table A1. Analytical methods used for the determination of organic and inorganic constituents by the U.S. Geological Survey (USGS) National Water Quality Laboratory (NWOL) and additional contract laboratories.-Continued

[Laboratory entity codes in the U.S. Geological Survey (USGS) National Water Information System (NWIS) for laboratories other than the USGS National Water Quality Laboratory (NWQL) are given in parentheses after the laboratory names. Abbreviations: UV, ultraviolet; VOCs, volatile organic compounds]

\begin{tabular}{|c|c|c|c|}
\hline Analyte & $\begin{array}{l}\text { Analytical } \\
\text { method }\end{array}$ & $\begin{array}{l}\text { Laboratory and } \\
\text { analytical schedule }\end{array}$ & Citation(s) \\
\hline \multicolumn{4}{|c|}{ Stable isotopes } \\
\hline Carbon isotopes & Accelerator mass spectrometry & $\begin{array}{l}\text { Woods Hole } \\
\text { Oceanographic Institution, } \\
\text { National Ocean Sciences } \\
\text { Accelerator Mass } \\
\text { Spectrometry Facility } \\
\text { (NOSAMS), NWQL } \\
\text { Schedule } 2015\end{array}$ & $\begin{array}{l}\text { Karlen and others, 1964; Olsson, 1970; } \\
\text { Stuiver, 1980; Stuiver and Polach, } 1977\end{array}$ \\
\hline \multicolumn{4}{|c|}{ Radioactivity and gases } \\
\hline Tritium & $\begin{array}{l}\text { Electrolytic enrichment-liquid scintil- } \\
\text { lation }\end{array}$ & $\begin{array}{l}\text { USGS Stable Isotope and } \\
\text { Tritium Laboratory, } \\
\text { Menlo Park, California } \\
\text { (USGSH3CA) }\end{array}$ & Thatcher and others, 1977 \\
\hline Tritium and noble gases & $\begin{array}{l}\text { Helium-3 in-growth and mass spec- } \\
\text { trometry }\end{array}$ & $\begin{array}{l}\text { Lawrence Livermore } \\
\text { National Laboratory } \\
\text { (CA-LLNL) }\end{array}$ & $\begin{array}{l}\text { Moran and others, 2002; Eaton and } \\
\text { others, } 2004\end{array}$ \\
\hline Radon-222 & Liquid scintillation counting & NWQL, Schedule 1369 & $\begin{array}{l}\text { American Society for Testing and } \\
\text { Materials, } 1998\end{array}$ \\
\hline $\begin{array}{l}\text { Gross alpha and gross } \\
\text { beta radioactivity }\end{array}$ & Alpha and beta activity counting & $\begin{array}{l}\text { Eberline Analytical } \\
\text { Services, NWQL } \\
\text { Schedule } 1792\end{array}$ & $\begin{array}{l}\text { Kreiger and Whittaker, } 1980 \text { (USEPA } \\
\text { method 900.0) }\end{array}$ \\
\hline
\end{tabular}


Table A2. Preferred analytical schedules for constituents appearing on multiple schedules, for samples collected for the South Coast Interior Basins Groundwater Ambient Monitoring and Assessment (GAMA) study, California, August to December 2008.

[Preferred analytical schedules are generally the methods of analysis with the greatest accuracy and precision out of the ones used for the compound in question except in cases where consistency with historic data analyzed using the same method is preferred. Abbreviations: LLNL, Lawrence Livermore National Laboratory; SITL, U.S. Geological Survey Stable Isotope and Tritium Laboratory; TML, U.S. Geological Survey Trace Metal Laboratory, Boulder, Colorado; np, no preference]

\begin{tabular}{|c|c|c|c|}
\hline Constituent & $\begin{array}{l}\text { Primary constituent } \\
\text { classification }\end{array}$ & $\begin{array}{l}\text { Analytical } \\
\text { schedules }\end{array}$ & $\begin{array}{c}\text { Preferred } \\
\text { analytical } \\
\text { schedule }\end{array}$ \\
\hline \multicolumn{4}{|c|}{ Results from preferred method reported } \\
\hline Atrazine & Pesticide & 2003,2060 & 2003 \\
\hline Caffeine & Wastewater indicator & 2080,2060 & 2060 \\
\hline Tebuthiuron & Pesticide & 2003,2060 & 2003 \\
\hline \multicolumn{4}{|c|}{ Results from both methods reported } \\
\hline Alkalinity & Water-quality indicator & Field, 1948 & field \\
\hline Arsenic, total & Trace element & 1948, TML & 1948 \\
\hline Chromium, total & Trace element & 1948, TML & 1948 \\
\hline
\end{tabular}

Table A3. Constituents detected in field blanks collected for the South Coast Interior Basins Groundwater Ambient Monitoring and Assessment (GAMA) study, California, August to December 2008.

[V-coded data are reported but not used in summary statistics. Abbreviations: E, estimated or having a higher degree of uncertainty; $\mathrm{pCi} / \mathrm{L}$, picocuries per liter; mg/L, milligrams per liter; $\mu \mathrm{g} / \mathrm{L}$, micrograms per liter; $\leq$, less than or equal to]

\begin{tabular}{|c|c|c|c|}
\hline Constituent & $\begin{array}{c}\text { Number of } \\
\text { field blank } \\
\text { detections/ } \\
\text { analyses }\end{array}$ & $\begin{array}{l}\text { Concentrations } \\
\text { detected in } \\
\text { field blanks }\end{array}$ & $\begin{array}{c}\text { Number of } \\
\text { groundwater } \\
\text { samples } \\
\text { V-coded } \\
\text { with } \leq\end{array}$ \\
\hline \multicolumn{4}{|c|}{ Organic constituents ( $\mu \mathrm{g} / \mathrm{L})$} \\
\hline Chloroform (Trichloromethane) & $1 / 6$ & E0.02 & 4 \\
\hline Atrazine & $1 / 6$ & E0.008 & 3 \\
\hline \multicolumn{4}{|c|}{ Major and minor ions (mg/L) } \\
\hline Silica $\left(\right.$ as $\left.\mathrm{SiO}_{2}\right)$ & $1 / 6$ & E0.015 & 0 \\
\hline \multicolumn{4}{|c|}{ Inorganic constituents $(\mu \mathrm{g} / \mathrm{L})$} \\
\hline Chromium & $1 / 6$ & 0.15 & 15 \\
\hline Copper & $1 / 6$ & 1.28 & 18 \\
\hline Nickel & $1 / 6$ & E0.12 & 7 \\
\hline Zinc & $1 / 6$ & E1.25 & 20 \\
\hline \multicolumn{4}{|c|}{ Radioactive constituents (pCi/L) } \\
\hline $\begin{array}{l}\text { Gross alpha radioactivity } \\
\text { (72-hour count) }\end{array}$ & $1 / 2$ & $0.19 \pm 0.15$ & 0 \\
\hline
\end{tabular}


Table A4A. Quality-control summary for replicate analyses of organic constituents detected in samples collected for the South Coast Interior Basins Groundwater Ambient Monitoring and Assessment (GAMA) study, California, August to December 2008.

[Abbreviations: SD, percent standard deviation; RSD, percent relative standard deviation; LRL, laboratory reporting limit; V, analyte detected in samples and blanks thus result is not considered a detection for groundwater quality assessment; $\mu \mathrm{g} / \mathrm{L}$, micrograms per liter; nv, no value in category]

\begin{tabular}{|c|c|c|c|}
\hline Constitutent & $\begin{array}{c}\text { Number of } \\
\text { nondetects/ } \\
\text { number of } \\
\text { replicates }\end{array}$ & $\begin{array}{l}\text { Number of } \\
\text { V-coded } \\
\text { replicates }\end{array}$ & 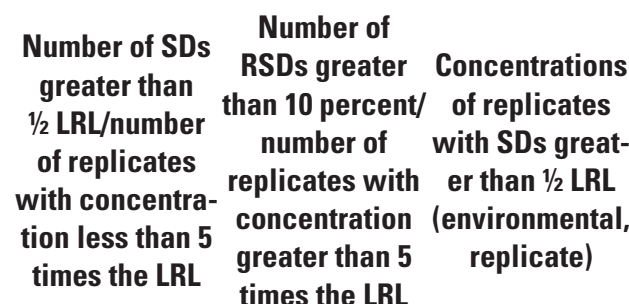 \\
\hline
\end{tabular}

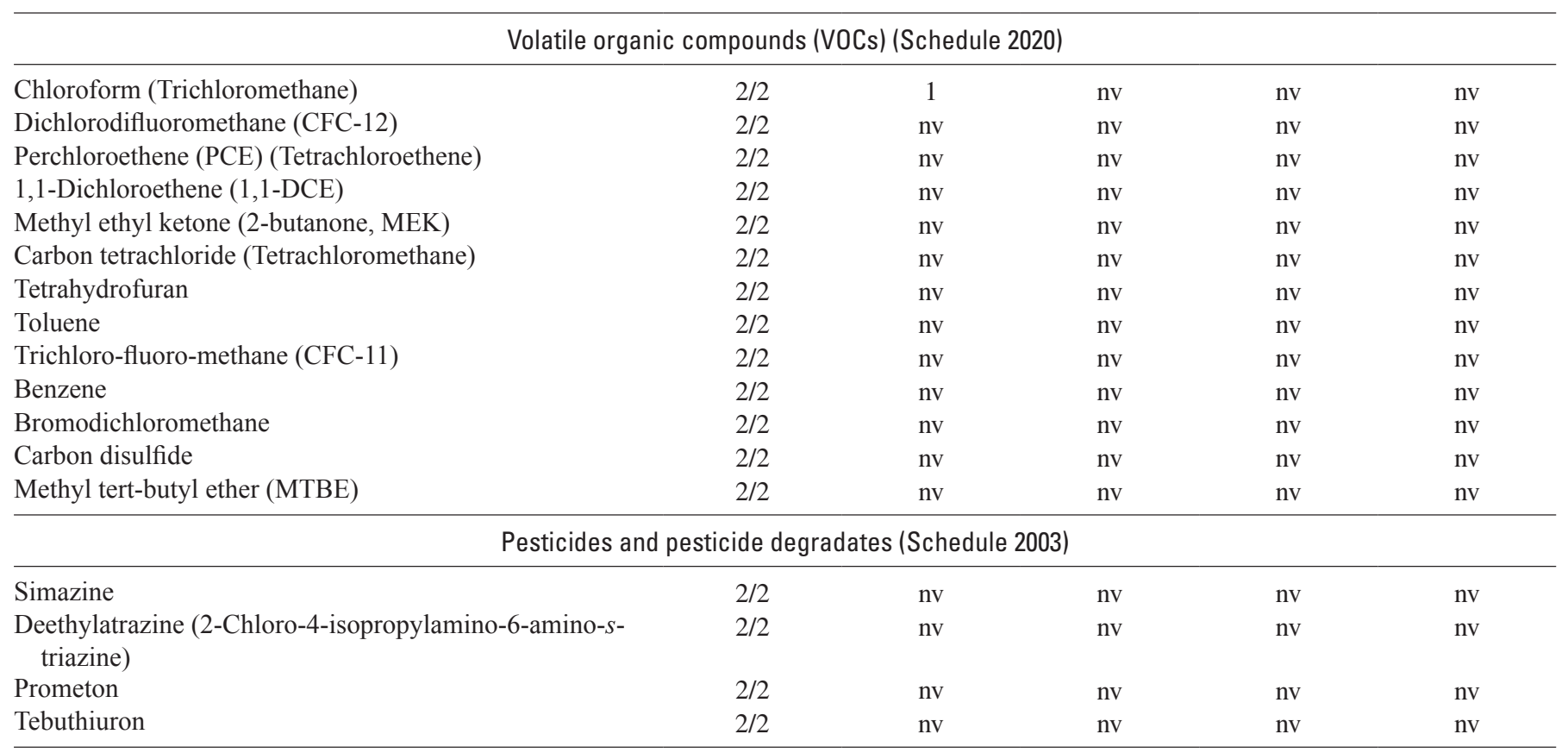

Polar pesticides and metabolies (Schedule 2060) ${ }^{1}$

\begin{tabular}{llcllll}
\hline Bentazon & $0 / 0$ & & & \\
\hline & \multicolumn{4}{c}{ Constituents of special interest } & & \\
\hline Perchlorate & $1 / 2$ & nv & nv & $1 / 2$ & $(1.3,0.30)$ \\
\hline
\end{tabular}

${ }^{1}$ No replicate analysis were performed for SC2060 samples. 
Table A4B. Quality-control summary for replicate analyses of trace elements, major and minor ions, silica, total dissolved solids (TDS), nutrients, and isotope tracers detected in samples collected for the South Coast Interior Basins Groundwater Ambient Monitoring and Assessment (GAMA) study, California, August to December 2008.

[Abbreviations: SD, percent standard deviation; RSD, percent relative standard deviation in percent; LRL, laboratory reporting limit; $\mu \mathrm{g} / \mathrm{L}$, micrograms per liter; $\mathrm{mg} / \mathrm{L}$, milligrams per liter; $\leq$ less than or equal to; nv, no value in category]

\begin{tabular}{|c|c|c|c|c|c|}
\hline Constitutent & $\begin{array}{l}\text { Number of } \\
\text { nondetect or } \\
\leq \text {-coded repli- } \\
\text { cates/number of } \\
\text { replicates }\end{array}$ & $\begin{array}{l}\text { Number of SDs } \\
\text { greater than } \\
1 / 2 \text { LRL/ number } \\
\text { of replicates } \\
\text { with concentra- } \\
\text { tion less than } 5 \\
\text { times the LRL }\end{array}$ & $\begin{array}{l}\text { Concentrations } \\
\text { of replicates } \\
\text { with SDs } \\
\text { greater than } \\
1 / 2 \text { LRL }\end{array}$ & $\begin{array}{l}\text { Number of } \\
\text { RSDs greater } \\
\text { than } 10 \text { percent/ } \\
\text { number of } \\
\text { replicates with } \\
\text { concentration } \\
\text { greater than } 5 \\
\text { times the LRL }\end{array}$ & $\begin{array}{l}\text { Concentrations } \\
\text { of replicates } \\
\text { with RSDs } \\
\text { greater than } \\
10 \text { percent }\end{array}$ \\
\hline Aluminum & $1 / 2$ & $0 / 1$ & nv & nv & nv \\
\hline Antimony & $2 / 2$ & nv & $\mathrm{nv}$ & $\mathrm{nv}$ & nv \\
\hline Arsenic & $0 / 2$ & $\mathrm{nv}$ & nv & $0 / 2$ & $\mathrm{nv}$ \\
\hline Barium & $0 / 2$ & nv & nv & $0 / 2$ & $\mathrm{nv}$ \\
\hline Beryllium & $2 / 2$ & $\mathrm{nv}$ & nv & $\mathrm{nv}$ & $\mathrm{nv}$ \\
\hline Copper & $1 / 2$ & $0 / 1$ & nv & $\mathrm{nv}$ & nv \\
\hline Iron & $1 / 2$ & $\mathrm{nv}$ & nv & $0 / 1$ & nv \\
\hline Lead & $2 / 2$ & $\mathrm{nv}$ & nv & $\mathrm{nv}$ & $\mathrm{nv}$ \\
\hline Lithium & $0 / 2$ & $0 / 2$ & nv & nv & nv \\
\hline Manganese & $0 / 2$ & $0 / 1$ & nv & $0 / 1$ & nv \\
\hline Molybdenum & $0 / 2$ & $\mathrm{nv}$ & nv & $0 / 2$ & $\mathrm{nv}$ \\
\hline Nickel & $2 / 2$ & $\mathrm{nv}$ & nv & nv & $\mathrm{nv}$ \\
\hline Selenium & $1 / 2$ & nv & nv & $0 / 1$ & $\mathrm{nv}$ \\
\hline Silver & $2 / 2$ & $\mathrm{nv}$ & nv & $\mathrm{nv}$ & $\mathrm{nv}$ \\
\hline Strontium & $0 / 2$ & $\mathrm{nv}$ & nv & $0 / 2$ & nv \\
\hline Tungsten & $1 / 2$ & $0 / 1$ & nv & $\mathrm{nv}$ & $\mathrm{nv}$ \\
\hline Chloride & $0 / 2$ & nv & $\mathrm{nv}$ & $0 / 2$ & nv \\
\hline Fluoride & $0 / 2$ & $0 / 2$ & $\mathrm{nv}$ & $\mathrm{nv}$ & nv \\
\hline Iodide & $0 / 2$ & $0 / 2$ & nv & $\mathrm{nv}$ & nv \\
\hline Magnesium & $0 / 2$ & $\mathrm{nv}$ & nv & $0 / 2$ & nv \\
\hline Potassium & $0 / 2$ & nv & nv & $0 / 2$ & nv \\
\hline Silica $\left(\right.$ as $\left.\mathrm{SiO}_{2}\right)$ & $0 / 2$ & nv & nv & $0 / 2$ & nv \\
\hline Sodium & $0 / 2$ & $\mathrm{nv}$ & $\mathrm{nv}$ & $0 / 2$ & nv \\
\hline Sulfate & $0 / 2$ & nv & nv & $0 / 2$ & nv \\
\hline Total dissolved solids (TDS) & $0 / 2$ & $\mathrm{nv}$ & nv & $0 / 2$ & nv \\
\hline
\end{tabular}


Table A4B. Quality-control summary for replicate analyses of trace elements, major and minor ions, silica, total dissolved solids (TDS), nutrients, and isotope tracers detected in samples collected for the South Coast Interior Basins Groundwater Ambient Monitoring and Assessment (GAMA) study, California, August to December 2008. - Continued

[Abbreviations: SD, percent standard deviation; RSD, percent relative standard deviation in percent; LRL, laboratory reporting limit; $\mu \mathrm{g} / \mathrm{L}$, micrograms per liter; mg/L, milligrams per liter; $\leq$ less than or equal to; nv, no value in category]

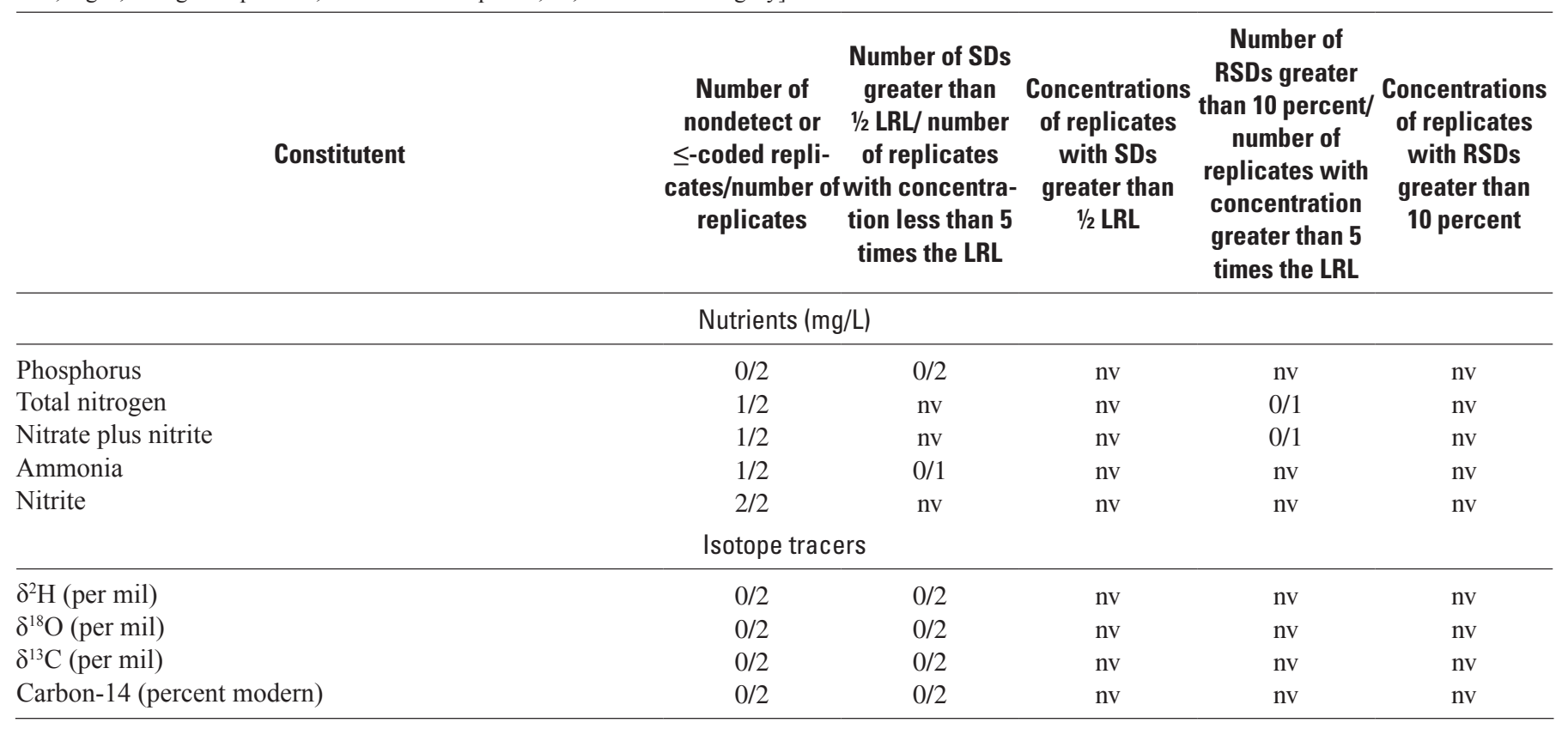


Table A5A. Quality-control summary for matrix-spike recoveries of volatile organic compounds (VOCs) in samples collected for the South Coast Interior Basins Groundwater Ambient Monitoring and Assessment (GAMA) study, California, August to December 2008.

[Acceptable recovery range is between 70 and 130 percent]

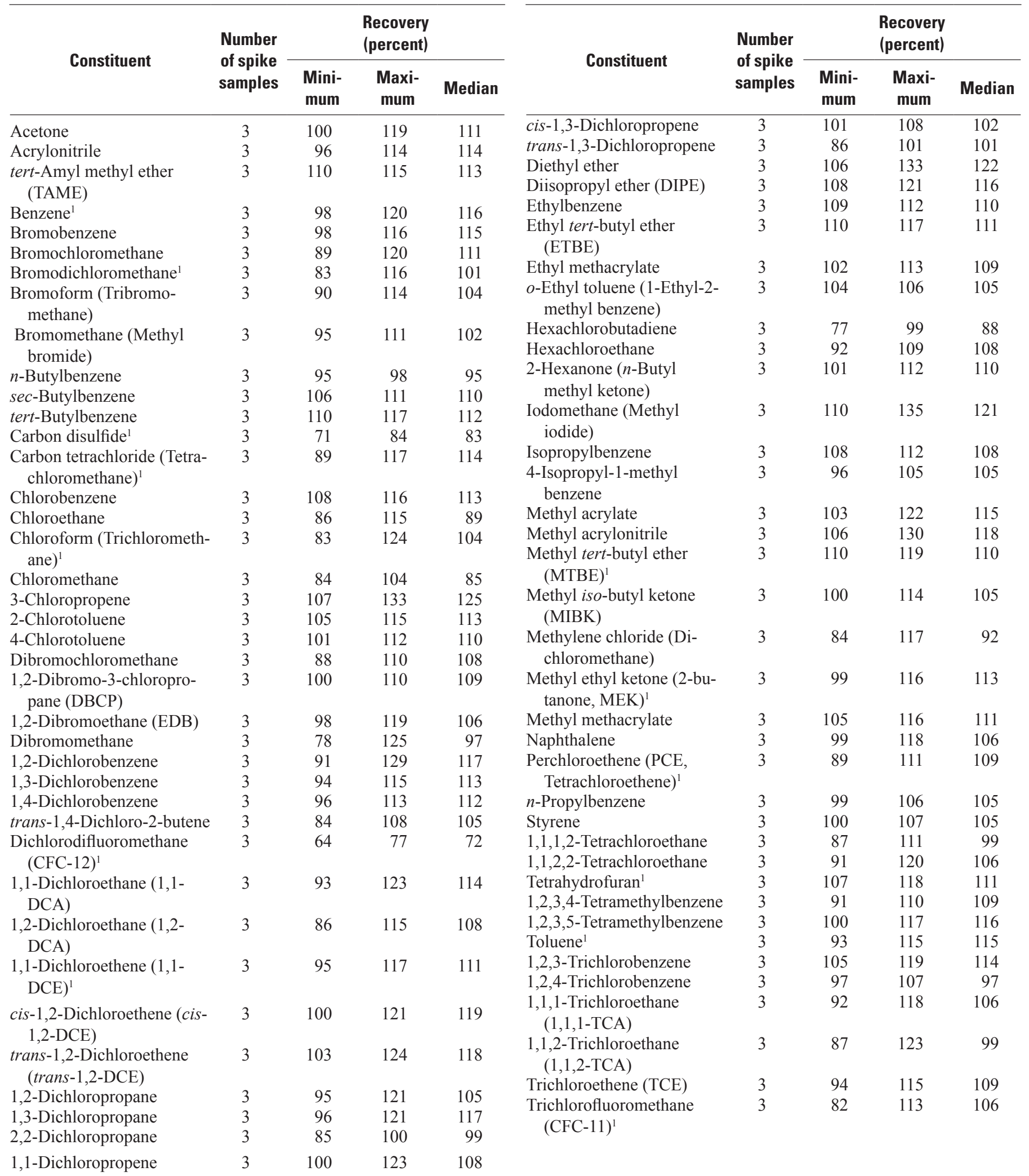


Table A5A. Quality-control summary for matrix-spike recoveries of volatile organic compounds (VOCs) in samples collected for the South Coast Interior Basins Groundwater Ambient Monitoring and Assessment (GAMA) study, California, August to December 2008.Continued

[Acceptable recovery range is between 70 and 130 percent]

\begin{tabular}{|c|c|c|c|c|c|c|c|c|c|}
\hline \multirow{2}{*}{ Constituent } & \multirow{2}{*}{$\begin{array}{l}\text { Number } \\
\text { of spike } \\
\text { samples }\end{array}$} & \multicolumn{3}{|c|}{$\begin{array}{l}\text { Recovery } \\
\text { (percent) }\end{array}$} & \multirow{2}{*}{ Constituent } & \multirow{2}{*}{$\begin{array}{l}\text { Number } \\
\text { of spike } \\
\text { samples }\end{array}$} & \multicolumn{3}{|c|}{$\begin{array}{l}\text { Recovery } \\
\text { (percent) }\end{array}$} \\
\hline & & $\begin{array}{c}\text { Mini- } \\
\text { mum }\end{array}$ & $\begin{array}{c}\text { Maxi- } \\
\text { mum }\end{array}$ & Median & & & $\begin{array}{c}\text { Mini- } \\
\text { mum }\end{array}$ & $\begin{array}{c}\text { Maxi- } \\
\text { mum }\end{array}$ & Median \\
\hline $\begin{array}{l}\text { 1,2,3-Trichloropropane } \\
\quad(1,2,3 \text {-TCP })\end{array}$ & 3 & 83 & 114 & 96 & $\begin{array}{l}\text { Vinyl bromide } \\
\text { (Bromoethene) }\end{array}$ & 3 & 91 & 111 & 102 \\
\hline $\begin{array}{l}\text { Trichlorotrifluoroethane } \\
\text { (CFC-113) }\end{array}$ & 3 & 74 & 100 & 85 & $\begin{array}{l}\text { Vinyl chloride } \\
\text { (Chloroethene) }\end{array}$ & 3 & 90 & 113 & 102 \\
\hline 1,2,3-Trimethylbenzene & 3 & 111 & 118 & 114 & $m$ - and $p$-Xylene & 3 & 109 & 111 & 111 \\
\hline $1,2,4$-Trimethylbenzene & 3 & 105 & 116 & 113 & $o$-Xylene & 3 & 104 & 110 & 109 \\
\hline $1,3,5$-Trimethylbenzene & 3 & 105 & 106 & 106 & & & & & \\
\hline
\end{tabular}

${ }^{1}$ Constituents detected in groundwater samples. 
Table A5B. Quality-control summary for matrix-spike recoveries of pesticides and pesticide degradates in samples collected for the South Coast Interior Basins Groundwater Ambient Monitoring and Assessment (GAMA) study, California, August to December 2008.

[Acceptable recovery range is between 70 and 130 percent]

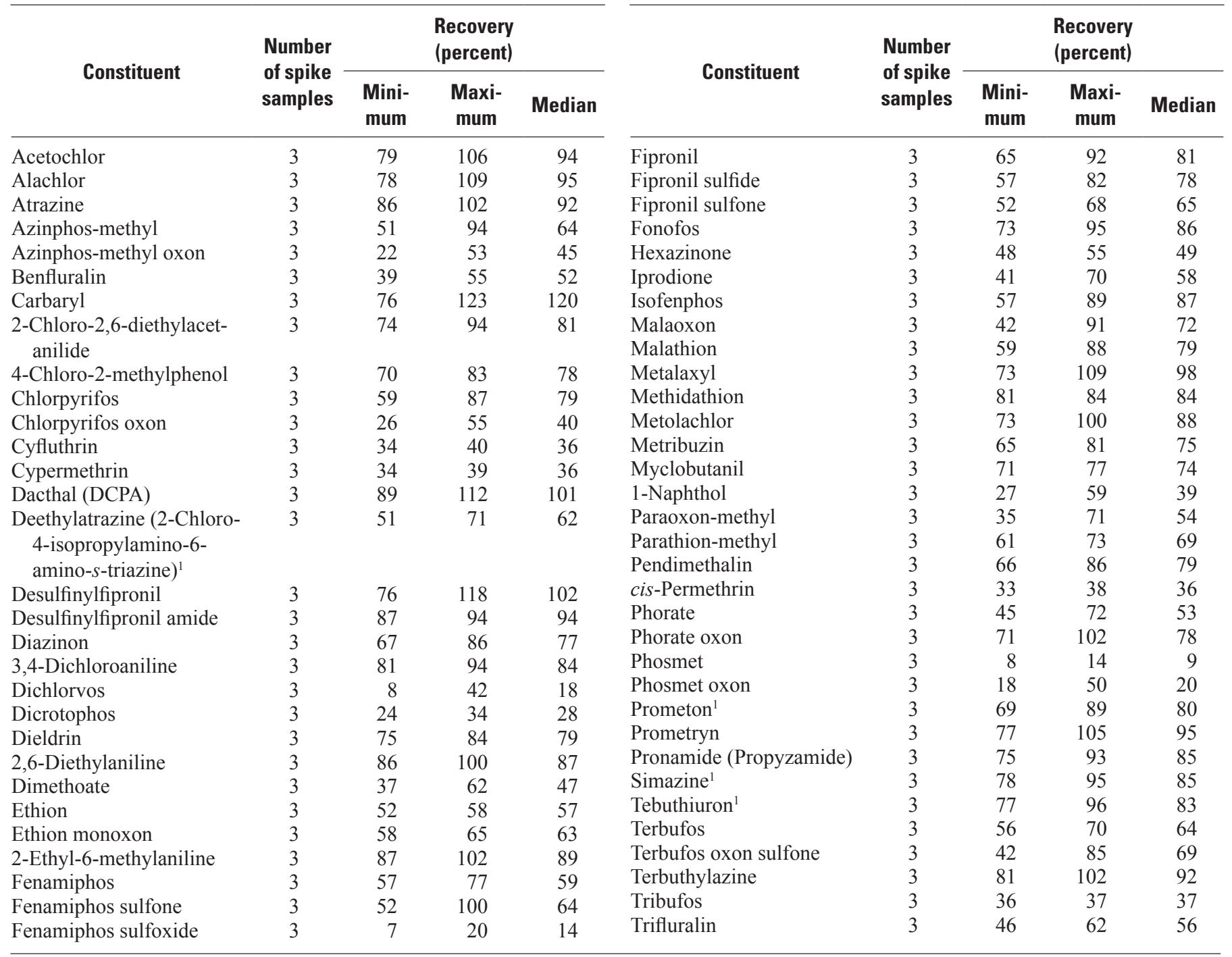

${ }^{1}$ Constituents detected in groundwater samples. 
Table A5C. Quality-control summary for matrix-spike recoveries of polar pesticides and metabolites in samples collected for the South Coast Interior Basins Groundwater Ambient Monitoring and Assessment (GAMA) study, California, August to December 2008.

[Acceptable recovery range is between 70 and 130 percent]

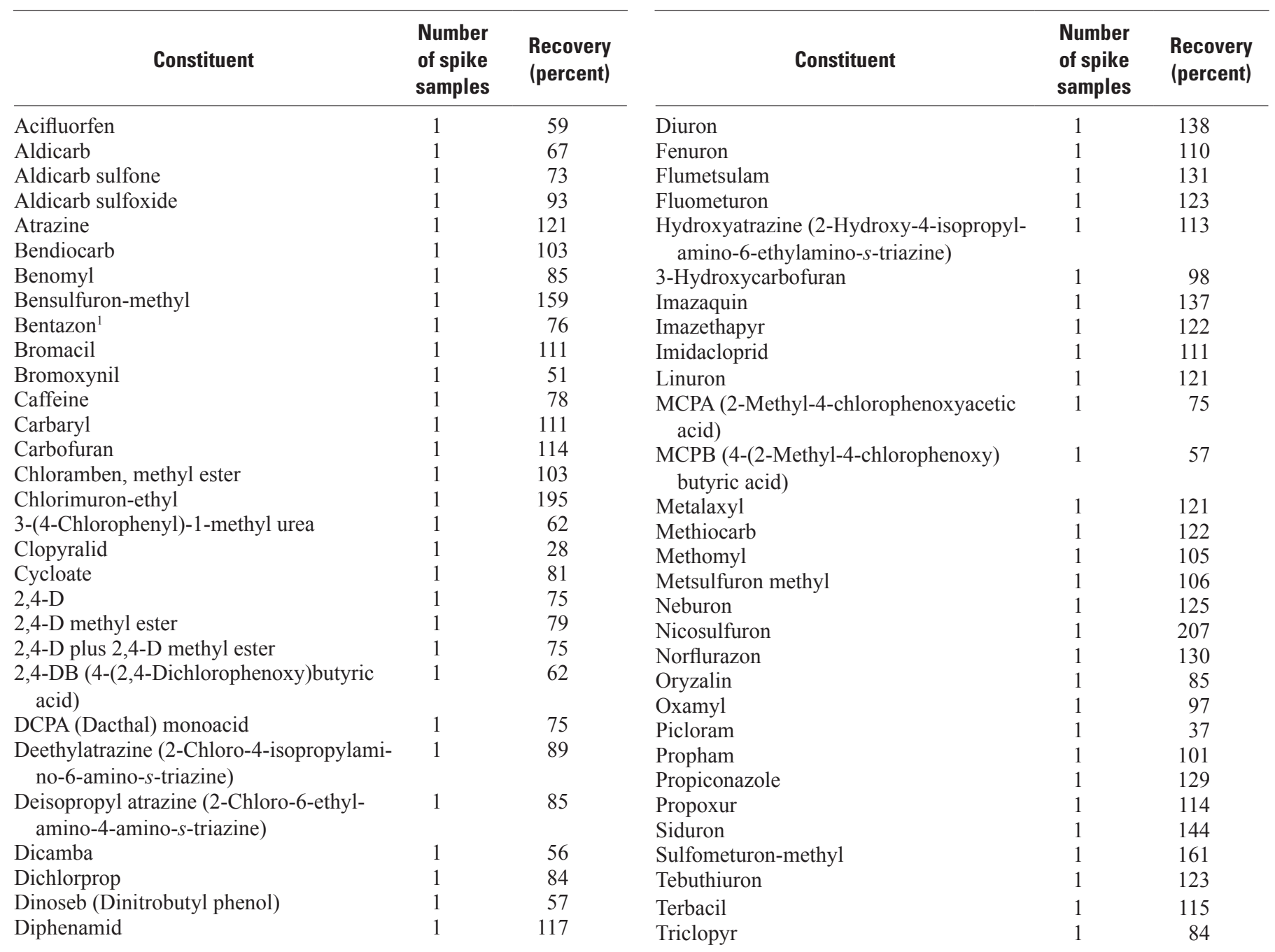

${ }^{1}$ Constituents detected in groundwater samples. 
Table A5D. Quality-control summary for matrix-spike recoveries of perchlorate and $\mathrm{N}$-nitrosodimethylamine (NDMA) in samples collected for the South Coast Interior Basins Groundwater Ambient Monitoring and Assessment (GAMA) study, California, August to December 2008.

[Acceptable recovery range is between 70 and 130 percent]

\begin{tabular}{lccccc}
\hline \multirow{2}{*}{ Constituent } & \multirow{2}{*}{\begin{tabular}{l} 
Number \\
of spike \\
\cline { 3 - 5 }
\end{tabular}} & & \multicolumn{3}{c}{ Recovery (percent) } \\
\cline { 3 - 5 } & samples & Minimum & Maximum & Median \\
\hline Perchlorate & & 4 & 101 & 112 & 110 \\
$N$-nitrosdimethylamine (NDMA) & 1 & & & ${ }^{1} 104$ \\
\hline
\end{tabular}

${ }^{1}$ Constituents detected in groundwater samples.

${ }^{2}$ Median recovery represented by the single spike value.

Table A6. Quality-control summary for surrogate recoveries of volatile organic compounds (VOCs), pesticides and pesticide degradates, and polar pesticides and metabolites in samples collected for the South Coast Interior Basins Groundwater Ambient Monitoring and Assessment (GAMA) study, California, August to December 2008.

[Abbreviation: VOC, volatile organic compound]

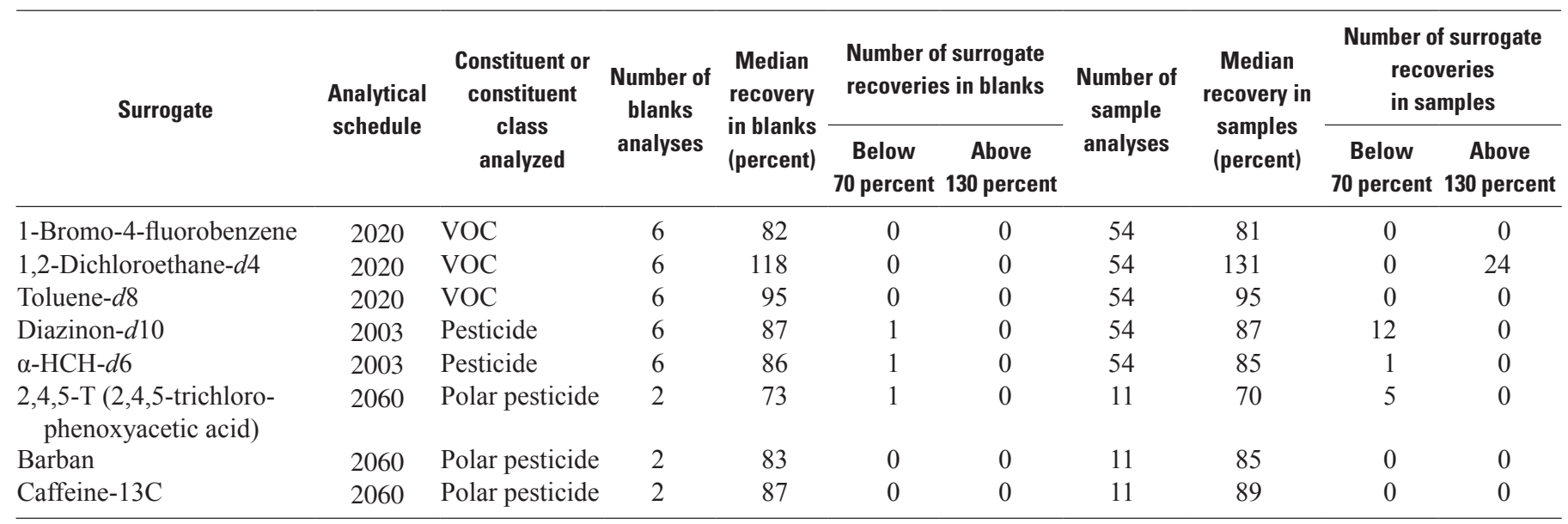


This page intentionally left blank. 
Manuscript approved for publication, August 11, 2009 Prepared by the USGS Enterprise Publishing Network, Publishing Service Center, Sacramento, California

For more information concerning the research in this report, contact the California Water Science Center Director,

U.S. Geological Survey, $6000 \mathrm{~J}$ Street

Sacramento, California 95819

http://ca.water.usgs.gov 


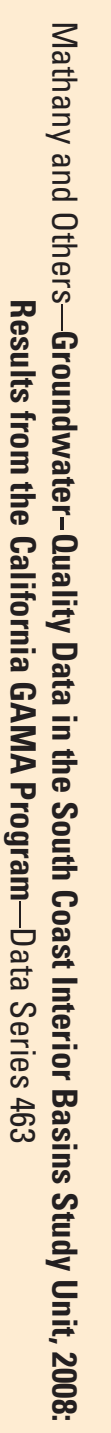

6 Printed on recycled paper 